Universidade de São Paulo-UsP

Escola de Engenharia de São Carlos

Departamento de Engenharia Elétrica e de Computação Programa de Pós-Graduação em Engenharia Elétrica

\title{
Denis Borg
}

Redes neurais e support vector machines como técnicas de diagnósticos em medições industriais de nível por tecnologia tipo radar sem contato e apoio à decisão para a melhoria de sua aplicação 



\section{Denis Borg}

\section{Redes neurais e support vector machines como técnicas de diagnósticos em medições industriais de nível por tecnologia tipo radar sem contato e apoio à decisão para a melhoria de sua aplicação}

Tese de doutorado apresentada ao Programa de Engenharia Elétrica da Escola de Engenharia de São Carlos como parte dos requisitos para a obtenção do título de Doutor em Ciências.

Área de concentração: Sistemas Dinâmicos

Orientador: Dennis Brandão 
AUTORIZO A REPRODUÇÃO TOTAL OU PARCIAL DESTE TRABALHO, POR QUALQUER MEIO CONVENCIONAL OU ELETRÔNICO, PARA FINS DE ESTUDO E PESQUISA, DESDE QUE CITADA A FONTE.

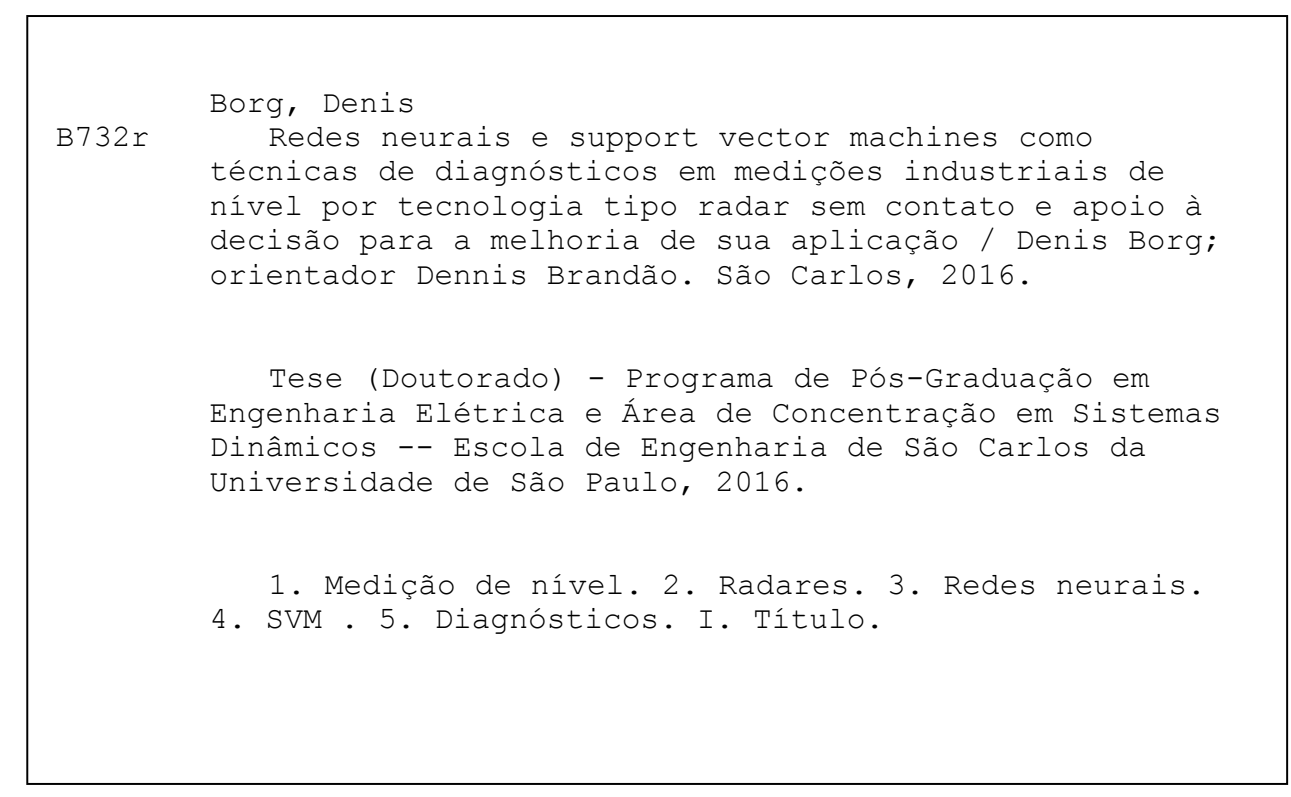




\section{FOLHA DE JULGAMENTO}

Candidato: Engenheiro DENIS BORG.

Título da tese: "Redes neurais e support vector machines como técnicas de diagnósticos em medições industriais de nível por tecnologia tipo radar sem contato e apoio à decisão para a melhoria de sua aplicação".

Data da defesa: 02.12.2016.

Comissão Julgadora:

Resultado:

Prof. Associado Dennis Brandão (Orientador)

(Escola de Engenharia de São Carlos/EESC)

Prof. Associado Rogério Andrade Flauzino

(Escola de Engenharia de São Carlos/EESC)
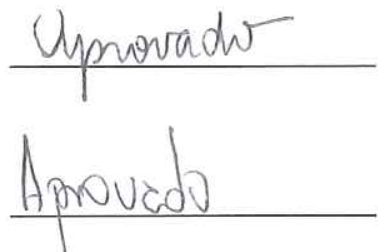

Prof. Dr. Paulo José Amaral Serni

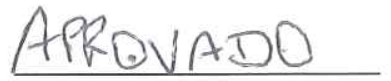

(Universidade Estadual Paulista "Júlio de Mesquita Filho"/UNESP - Sorocaba)

Prof. Dr. Osmar Ogashawara

(Universidade Federal de São Carlos/UFSCar)

Prof. Dr. Alexandre Baratella Lugli

(Instituto Nacional de Telecomunicações/INATEL)
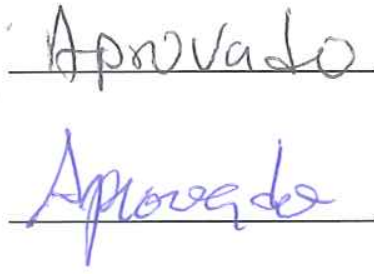

Coordenador do Programa de Pós-Graduação em Engenharia Elétrica: Prof. Associado Luis Fernando Costa Alberto

Presidente da Comissão de Pós-Graduação: Prof. Associado Luis Fernando Costa Alberto 

Este trabalho é dedicado à minha esposa Guillermina, à meus pais, Ênio e Lúcia, minha irmã Denise, meu cunhado Vicente (in memmoriam) e meu sobrinho, Devis. 



\section{Agradecimentos}

Os agradecimentos principais são direcionados ao Christoffer Widahl da Emerson Suécia pelo envio dos arquivos de medições dos radares. Aos amigos da Emerson Brasil, Carlos Cordeiro, Sandra Dionísio, Dinael Zuin, Felipe Franqueira, Leonardo Favero, José Guilherme Frauendorf, Tassilo Thuene e Flávio Barbosa pelo apoio. Em especial ao Emerson Sugarone pelas nossas discussões filosóficas sobre as aplicações de radares e ao Rômulo Rogato por ter sido um facilitador no contato com clientes. Ao Marcos Peluso, por facilitar o acesso ao pessoal da Suécia e pelas aulas sobre os fieldbuses. Ao meu orientador Dennis Brandão pelo direcionamento em todas as etapas do trabalho e amizade. Ao amigo professor Marcelo Suetake pelas dicas das técnicas estatísticas e do software Latex. À Luisa Liboni pelas sugestões com o software Weka. Aos professores de inglês Ricardo e Luciana Nardi pela ajuda com os textos dos artigos e revistas a serem publicadas.

À Elena L. Palloni Gonçalves da Biblioteca central da EESC pela revisão do documento da Tese.

À Deus e à Jesus pela existência e aprendizados ininterruptos. 

"O conhecimento humano é uma esfera que cresce incessantemente; à medida que aumenta o seu volume, cresce o número de pontos de contato com o desconhecido." (Blaise Pascal) 



\section{Resumo}

Borg, D. Redes neurais e support vector machines como técnicas de diagnósticos em medições industriais de nível por tecnologia tipo radar sem contato e apoio à decisão para a melhoria de sua aplicação. 146 p. Tese (Doutorado) - Escola de Engenharia de São Carlos, Universidade de São Paulo, São Carlos, 2016.

O objetivo dessa tese é detectar e classificar problemas de medição de nível por princípio de radar de propagação de onda livre por meio de RNA (redes neurais artificiais) e SVM (support vector machines) aliados à tratamentos estatísticos. Um primeiro cenário com ambiente controlado foi montado para a obtenção de dados preliminares. Na sequência, outros três cenários empregaram dados industriais reais. Para tanto, algumas topologias de redes neurais em quatro cenários diferentes foram testadas e foi possível demonstrar o funcionamento eficiente da RNA com acertos de $100 \%$ para o primeiro cenário, 93,51 \% para o segundo, 99,75\% para o terceiro e de 99,94 \% para o quarto cenário. Para esses mesmos quatro cenários, os resultados de classificação do SVM foram de $100 \%, 84,41 \%, 93,74 \%$ e de $96,40 \%$. Os resultados obtidos demonstram que a técnica desenvolvida pode ser aplicada à cenários reais de medição de nível. Após a classificação dos problemas pela RNA ou SVM é recomendada a utilização de alguns dos ícones baseados na norma internacional NAMUR NE107 para reportar as diferentes classificações de problemas resultantes da aplicação das técnicas dessa tese. Propõe-se que essas técnicas sejam embarcadas em aplicativos computacionais de gerenciamento de ativos para melhorar a confiabilidade da medição, antecipar rotinas de manutenção dos instrumentos e aumentar a segurança da planta industrial através de reportes adequados aos usuários dos problemas de medição de nível e do mapeamento das fases do processo.

Palavras-chave: Diagnósticos. Medição de nível. Radares. Redes neurais. SVM. 



\title{
Abstract
}

\author{
Borg, D. Neural networks and support vector machines as diagnosing \\ tool for industrial level measurement through non-contacting radar type and \\ support to the decision for its better application. 146 p. Ph.D. (Thesis) - \\ São Carlos School of Engineering, University of São Paulo, São Carlos, 2016.
}

The aim of this Thesis is to detect and classify level measurement problems by free wave propagation radars using ANN (artificial neural network) and SVM (support vector machines) with statistical pre-processing data. In the first scenario, a controlled environment was build in order to get the preliminary data. In addition, three other scenarios with real industry data was considered. Therefore, some topologies of neural networks and SVM in four different scenarios were tested and it was demonstrated the efficiency of ANN to reach an accuracy rate of $100 \%$ for the first scenario, $93.51 \%$ for the second, $99.75 \%$ for third and $99.94 \%$ for the fourth scenario. For these same four scenarios, the results of SVM classification were 100\%, 84.41\%, 93.74\% and 96.40\%. After classifying the problems by ANN or SVM, it is recommended to use some of the icons following the international standard NAMUR NE107 to report the different classifications of problems within this thesis. It is proposed that these techniques be embedded in asset management environment to improve the reliability of level measurement, antecipate maintenance routines and improve plant safety through adequately reporting the classified problems and mapping stage of the process to the users.

Keywords: Diagnostics. Level measurement. Radars. Neural networks. SVM. 



\section{Lista de ilustrações}

Figura 1 Formas de se expressar a medição do nível. Fonte: Baseado em Rosemount (2013) . . . . . . . . . . . . . . . . . . . 30

Figura 2 Modelo de uma linha de transmissão. Fonte: Baseado em Nemarich (2001).

Figura 3 (a) TDR e dois segmentos coaxiais; (b) Diagrama de reflexão do pulso;

(c) Traço idealizado de um TDR no osciloscópio. Fonte: Baseado em Nemarich (2001). . . . . . . . . . . . . . . . . . . 35

Figura 4 Seção coaxial de uma antena. Fonte: Baseado em Nemarich (2001). . . 37

Figura 5 Sensor TDR de nível de fluido. Fonte: Baseado em Nemarich (2001). . 38

Figura 6 Aplicações de radares sem contato em reatores. Fonte: Rosemount (2014) . . . . . . . . . . . . . . . . . . . 40

Figura 7 Flexibilidade de instalação em flanges de 2 a 8 polegadas ou em válvulas isoladoras. Fonte: Rosemount (2014) . . . . . . . . . . . . . . . . . . . 41

Figura 8 Tanques subterrâneos. Fonte: Rosemount (2014). . . . . . . . . . . . . 41

Figura 9 Esquema de interligação do radar. Fonte: Baseado em Rosemount (2014). 42

Figura 10 Diferença de abertura do feixe de micro-ondas. Fonte: Baseado em Rosemount (2014). . . . . . . . . . . . . . . . . . . . . 44

Figura 11 Exemplo de curva de carga do radar. Fonte: Baseado em Rosemount

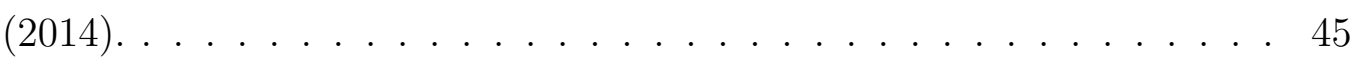

Figura 12 Ajustes avançados. . . . . . . . . . . . . . . . . . . 46

Figura 13 Ajustes de limiares de amplitude da curva do eco. Fonte: Baseado em Rosemount (2014). . . . . . . . . . . . . . . . . . . . 48

Figura 14 Hiperplanos da RNA. . . . . . . . . . . . . . . . . . . . . 64

Figura 15 Hiperplano do SVM. . . . . . . . . . . . . . . . . 65

Figura 16 Esquema de uma rede neural multicamadas perceptron. Fonte: Baseado em Silva, Spatti e Flauzino (2010). . . . . . . . . . . . . . . . . . . . . 66

Figura 17 Mapeamento de espaço X para F. Fonte: Baseado em Cristianini e Shawe-Taylor (2002) . . . . . . . . . . . . . . . . . . . 67 
Figura 18 Plano de trabalho. . . . . . . . . . . . . . . . . . . . . 73

Figura 19 Montagem da bancada de aquisição de dados. . . . . . . . . . . . . . . 74

Figura 20 Gráfico da distância pelas amostras. . . . . . . . . . . . . . . 75

Figura 21 Gráfico da amplitude pelas amostras. . . . . . . . . . . . 76

Figura 22 Gráfico da velocidade pelas amostras. . . . . . . . . . . . . . 76

Figura 23 Média das amplitudes. . . . . . . . . . . . . . . . . . . . 78

Figura 24 Média das distâncias. . . . . . . . . . . . . . . . . . . . . . 78

Figura 25 Variância das amplitudes. . . . . . . . . . . . . . . . 79

Figura 26 Variância das distâncias. . . . . . . . . . . . . . . . . . . . . 79

Figura 27 Desvio padrão das amplitudes. . . . . . . . . . . . . . . . . . 80

Figura 28 Desvio padrão das distâncias. . . . . . . . . . . . . . . . . . 80

Figura 29 Assimetria das amplitudes. . . . . . . . . . . . . . . . . . . 81

Figura 30 Assimetria das distâncias. . . . . . . . . . . . . . . . . . 81

Figura 31 Curtose das amplitudes. . . . . . . . . . . . . . . . . . . . . 82

Figura 32 Curtose das distâncias. . . . . . . . . . . . . . . . . . . . . . . 82

Figura 33 Tanque da seção do evaporador da usina. . . . . . . . . . . . . . . . . 84

Figura 34 Gráfico da distância pelo tempo. . . . . . . . . . . . . . . . . . 85

Figura 35 Gráfico da amplitude pelo tempo. . . . . . . . . . . . . . . 86

Figura 36 Gráfico da velocidade pelo tempo. . . . . . . . . . . . . . . . . 86

Figura 37 Foto da instalação do radar no topo do tanque. . . . . . . . . . . . . . 87

Figura 38 Gráfico dos problemas para treinamento da RNA. . . . . . . . . . . 89

Figura 39 Gráfico da distância pelo tempo. . . . . . . . . . . . . . . . . . 89

Figura 40 Gráfico da amplitude pelo tempo. . . . . . . . . . . . . . . . . 90

Figura 41 Gráfico da média das amplitudes pelo tempo. . . . . . . . . . . . . . 90

Figura 42 Gráfico do desvio padrão pelo tempo. . . . . . . . . . . . . . . . 91

Figura 43 Gráfico da velocidade pelo tempo. . . . . . . . . . . . . . . . . 91

Figura 44 Gráfico da amplitude pela distância. . . . . . . . . . . . . . . 92

Figura 45 Gráfico dos problemas para treinamento da RNA. . . . . . . . . . . . . 93

Figura 46 Gráfico da distância pelo tempo. . . . . . . . . . . . . . . . . 93

Figura 47 Gráfico da amplitude pelo tempo. . . . . . . . . . . . . . . . 94

Figura 48 Gráfico da velocidade pelo tempo. . . . . . . . . . . . . . . . 95

Figura 49 Gráfico da média das amplitudes pelo tempo. . . . . . . . . . . . . . 95

Figura 50 Gráfico do desvio padrão das amplitudes pelo tempo. . . . . . . . . . . 96

Figura 51 Escolha da variável e do tipo de medidor. . . . . . . . . . . . . . . 124

Figura 52 Inserção do tag e dados do processo. . . . . . . . . . . . . . . . 125

Figura 53 Configuração do fluido e constante dielétrica. . . . . . . . . . . . . . . 125

Figura 54 Configuração da geometria do tanque . . . . . . . . . . . . . . . 126

Figura 55 Configuração dos detalhes da montagem. . . . . . . . . . . . . . . 126

Figura 56 Configuração da altura do flange do radar. . . . . . . . . . . . . . 127 
Figura 57 Análise da altura medida dependendo do tamanho da antena e da constante dielétrica do fluido do processo. . . . . . . . . . . . . . . 128

Figura 58 Configuração da antena do radar . . . . . . . . . . . . . . . . . 128

Figura 59 Escolha do relatório para visualização ou impressão. . . . . . . . . . . . . 129

Figura 60 Modelo completo e validado pelo toolkit. . . . . . . . . . . . . . . . . . 129

Figura 61 Gráfico da distância pelo tempo. . . . . . . . . . . . . . . . 133

Figura 62 Gráfico da amplitude pelo tempo. . . . . . . . . . . . . . . . 134

Figura 63 Gráfico da velocidade pelo tempo. . . . . . . . . . . . . . . . 134

Figura 64 Estrutura do cabeçalho do arquivo "arff". . . . . . . . . . . . . . . . . 144

Figura 65 Seleção do arquivo de teste. . . . . . . . . . . . . . . . . . . . . . 145

Figura 66 Seleção do tipo do classificador e de suas propriedades. . . . . . . . . . 146 



\section{Lista de tabelas}

Tabela 1 Visão geral sobre os medidores de nível e condições do processo . . . . 31

Tabela 2 Limites de pressão e temperatura dos medidores de vazão . . . . . . . . 32

Tabela 3 Faixa máxima de medição para o radar de alta frequência em pés (metros) 43

Tabela 4 Faixa máxima de medição para o radar de baixa frequência em pés (metros) . . . . . . . . . . . . . . . . . . 44 44

Tabela 5 Ajustes avançados. . . . . . . . . . . . . . . . 47

Tabela 6 Categorização de problemas em instrumentos de campo . . . . . . . . . 50

Tabela 7 Exemplos de diagnósticos para radares. Fonte: Baseado em NAMUR

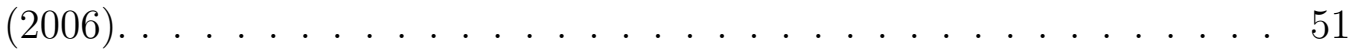

Tabela $8 \quad$ Labels de correspondência entre RNA e SVM. . . . . . . . . . . . . . 98

Tabela 9 Resultados do treinamento apenas com os dados do arquivo EP. . . . . 99

Tabela 10 Resultados das entradas defasadas no tempo. . . . . . . . . . . . . . . 99

Tabela 11 Resultados do pré-processamento estatístico com j=2 . . . . . . . . . 100

Tabela 12 Resultados do pré-processamento estatístico com j=3. . . . . . . . . 100

Tabela 13 Resultados do pré-processamento estatístico com j=5 . . . . . . . . . 100

Tabela 14 Resultados do pré-processamento estatístico com $\mathrm{j}=7$. . . . . . . . . . 101

Tabela 15 Resultados do pré-processamento estatístico com j=9. . . . . . . . . 101

Tabela 16 SVM: Resultados do primeiro cenário. . . . . . . . . . . . . . . . . . . 101

Tabela 17 Resultados do treinamento da rede com as entradas de EP. . . . . . . . 102

Tabela 18 Resultados do treinamento com as entradas de $\mu$ e $\sigma$ com elementos tomados 2 a $2 \ldots \ldots \ldots \ldots$. . . . . . . . . . . . . . . . . . . . . . .

Tabela 19 Resultados do treinamento com as entradas de $\mu$ e $\sigma$ com elementos

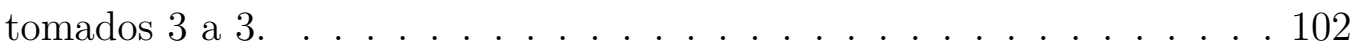

Tabela 20 Resultados do treinamento com as entradas de $\mu$ e $\sigma$ com elementos

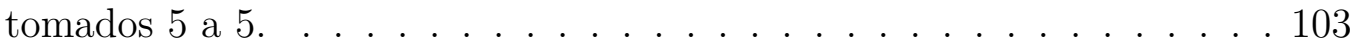

Tabela 21 Resultados do treinamento com as entradas de $\mu$ e $\sigma$ com elementos tomados 7 a $7 \ldots \ldots \ldots$. . . . . . . . . . . . . . . . . . . . . . . . 
Tabela 22 Resultados do treinamento com as entradas de $\mu$ e $\sigma$ com elementos

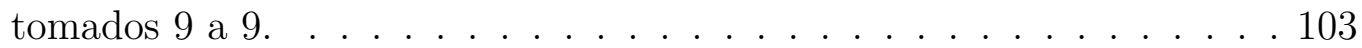

Tabela 23 SVM: Resultados do segundo cenário. . . . . . . . . . . . . . . . . . . 104

Tabela 24 Resultados do treinamento com as entradas de $\mu$ e $\sigma$ com elementos tomados 2 a 2 . . . . . . . . . . . . . . . . . . . . . . 104

Tabela 25 Resultados do treinamento com as entradas de $\mu$ e $\sigma$ com elementos

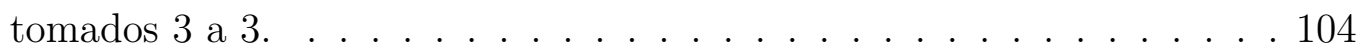

Tabela 26 Resultados do treinamento com as entradas de $\mu$ e $\sigma$ com elementos

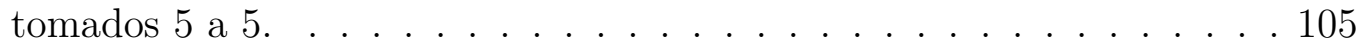

Tabela 27 Resultados do treinamento com as entradas de $\mu$ e $\sigma$ com elementos

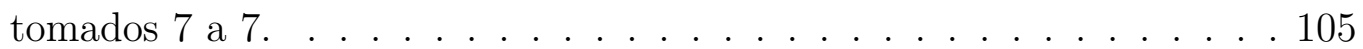

Tabela 28 Resultados do treinamento com as entradas de $\mu$ e $\sigma$ com elementos

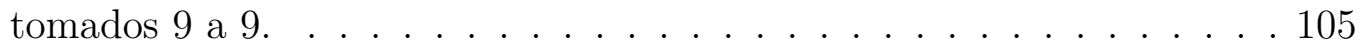

Tabela 29 SVM: Resultados do terceiro cenário. . . . . . . . . . . . . . . . 106

Tabela 30 Resultados do treinamento com as entradas de $\mu$ e $\sigma$ com elementos tomados 2 a $2 \ldots \ldots \ldots \ldots$. . . . . . . . . . . . . . . . . . . . . . . .

Tabela 31 Resultados do treinamento com as entradas de $\mu$ e $\sigma$ com elementos tomados 3 a $3 . \ldots \ldots \ldots$. . . . . . . . . . . . . . 106

Tabela 32 Resultados do treinamento com as entradas de $\mu$ e $\sigma$ com elementos

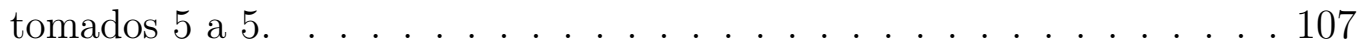

Tabela 33 Resultados do treinamento com as entradas de $\mu$ e $\sigma$ com elementos

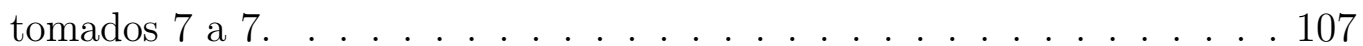

Tabela 34 Resultados do treinamento com as entradas de $\mu$ e $\sigma$ com elementos

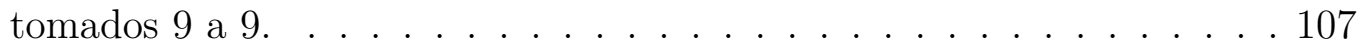

Tabela 35 SVM: Resultados do quarto cenário. . . . . . . . . . . . . . . . . 108

Tabela 36 Comparação do desempenho dos classificadores . . . . . . . . . . . . . 108

Tabela 37 Sugestão de implementação da NAMUR NE107 aplicada às classificações de problemas. Primeiro cenário. . . . . . . . . . . . . . . . . . . . 110

Tabela 38 Sugestão de implementação da NAMUR NE107 aplicada às classificações de problemas. Segundo cenário. . . . . . . . . . . . . . . . . . . 110

Tabela 39 Sugestão de implementação da NAMUR NE107 aplicada às classificações de problemas. Terceiro cenário. . . . . . . . . . . . . . . . . . . 110

Tabela 40 Sugestão de implementação da NAMUR NE107 aplicada às classificações de problemas. Quarto cenário. . . . . . . . . . . . . . . . . . . . . 110

Tabela 41 Guia de modelo e antena . . . . . . . . . . . . . . . . . . . 132 


\section{Lista de siglas}

ABNT Associação Brasileira de Normas Técnicas

API American Petroleum Institute.

CD Constante dielétrica do fluido a ser medido.

CDS Configuration datasheet. Folha de dados utilizada para a configuração do radar.

PD Pressão diferencial.

FMCW Frequency Modulated Continuous Wave.

FF Foundation Fieldbus.

GWR Guided Wave Radar. Radar de ondas guiadas.

HART Highway Addressable Remote Transducer.

OIML International Organization of Legal Metrology.

Radar Radio Detecting and Ranging.

RTD Resistance Temperature Detector.

SIS Safety Instrumented System. Sistemas instrumentados de segurança.

SVM Support vector machines.

TOF Time of flight. Tempo decorrido desde que o sinal deixa o emissor até chegar ao detector.

TDR Time Domain Reflectometry. Reflectometria no domínio do tempo.

WEKA Waikato Environment for Knowledge Analysis. 



\section{Sumário}

1 Introdução à Tese 25

1.1 Introdução . . . . . . . . . . . . . . . . . . . . . . . . . 25

1.2 Objetivos e contribuição original da Tese . . . . . . . . . . . . . 26

1.3 Trabalhos desenvolvidos e estrutura do texto da Tese . . . . . . . . . . . . 26

$2 \quad$ A medição de nível por radares $\quad 29$

2.1 Medidores de nível e suas limitações . . . . . . . . . . . . . . . . . . . . . 30

2.2 A tecnologia TDR . . . . . . . . . . . . . . . . . 32

2.3 Medindo nível por TDR . . . . . . . . . . . . . . . . . . . 36

2.4 Exemplos das principais aplicações com radares sem contato . . . . . . . . 39

2.5 Características do processo . . . . . . . . . . . . . . . . . . . . 41

2.6 Dimensionamento do radar . . . . . . . . . . . . . . . . . . . 42

2.6.1 Configuração do radar e ajustes avançados . . . . . . . . . . . . . 44

2.7 Adequação da indicação e reporte de diagnósticos de nível conforme NAMUR NE107 . . . . . . . . . . . . . . . . . . . . . . . . . . . 48

2.8 Revisão bibliográfica . . . . . . . . . . . . . . . . . . . 52

2.9 Procura por patentes . . . . . . . . . . . . . . . . . . . 61

$3 \quad$ Classificadores: SVM e RNA $\quad 63$

4 Desenvolvimento da técnica para aplicação dos classificadores tipo RNA e SVM $\quad 71$

4.1 Primeiro cenário . . . . . . . . . . . . . . . . . . . . . . . . . 74

4.2 Segundo cenário . . . . . . . . . . . . . . . . . . . 83

4.3 Terceiro cenário . . . . . . . . . . . . . . . . . . . . . . . 87

4.4 Quarto cenário . . . . . . . . . . . . . . . . . . . . 92

$5 \quad$ Resultados e discussões $\quad 97$

5.1 Configurações utilizadas do SVM e RNA . . . . . . . . . . . . . . . . 97 
5.1.1 Resultados do primeiro cenário . . . . . . . . . . . . . . . . 99

5.1 .2 Resultados do SVM para o primeiro cenário . . . . . . . . . . . . . 101

5.2 Reconhecimento da fase do processo industrial . . . . . . . . . . . . 101

5.3 Resultados do segundo cenário . . . . . . . . . . . . . . . . . . 102

5.3.1 Resultados do SVM para o segundo cenário. . . . . . . . . . . . 103

5.4 Resultados do terceiro cenário . . . . . . . . . . . . . . . . . 104

5.4.1 Resultados do SVM para o terceiro cenário . . . . . . . . . . 105

5.5 Resultados do quarto cenário . . . . . . . . . . . . . . . . 106

5.5.1 Resultados do SVM para o quarto cenário . . . . . . . . . . . . 107

5.6 Comparação dos resultados dos classificadores . . . . . . . . . . . . . . 108

5.7 Aplicação da norma NAMUR NE107 às classificações obtidas . . . . . . . 109

Conclusão

APÊNDICE C Gráficos da distância, amplitude e velocidade em relação ao tempo 


\section{Introdução à Tese}

\subsection{Introdução}

Há pouco mais de dez anos, os radares de micro-ondas não eram uma solução comum para a medição de nível em processos industriais. Os principais motivos para isso foram o desconhecimento da tecnologia e seu preço relativamente maior do que outros métodos para se medir o nível. Os avanços tecnológicos na microeletrônica para micro-ondas realizados de dez anos para cá, todavia tornam possível a sua utilização em ambientes industriais, onde desafios únicos são apresentados em Kielb (1999). Mesmo com todas as melhorias incorporadas aos radares, algumas aplicações ainda são desafiadoras para a sua aplicação como medições em fluidos de baixa constante dielétrica, presença de vapor, espuma, agitação e depósitos de material na superfície da antena. Portanto, uma ferramenta de diagnóstico que possa servir como apoio à decisão para se ter uma medição de nível aperfeiçoada, seria uma contribuição original no cenário científico e tecnológico dos radares. Para o preenchimento dessa lacuna, a técnica proposta nesta tese foi desenvolvida.

A decisão de se utilizar o radar ou outra tecnologia na medição de nível em áreas industriais, nasce, normalmente durante o projeto de engenharia básica onde os tamanhos dos tanques, faixas de pressão, temperatura, nível, densidade e viscosidade do fluido, entre outras características do projeto são estimadas.

A partir das informações do processo e dos dados de instalação, os instrumentos para medição de nível, entre eles o radar, são estudados e dimensionados. Após o dimensionamento, normalmente se procede com a compra e instalação desses instrumentos. Essas fases de dimensionamento do radar e sua instalação devem ser feitas da forma mais criteriosa possível para evitar problemas de medição. Mesmo nessa situação, existem algumas aplicações que são desafiadoras como as que ocorrem na presença de espuma e/ou vapor, turbulência da superfície do liquido, constante dielétrica muito baixa aliado à tanques altos, e para se conseguir uma medição melhor, é desenvolvido nesta tese um estudo a partir dos gráficos do software do radar com o emprego de técnicas de análises estatísticas 
aliada à sistemas inteligentes.

\subsection{Objetivos e contribuição original da Tese}

O objetivo dessa tese é detectar e classificar problemas de medição de nível por princípio de radar de propagação de onda livre por meio de RNA (redes neurais artificiais) e SVM (support vector machines) aliados à tratamentos estatísticos. A classificação correta de qual fase o processo está pode funcionar como um soft-sensor aumentando a segurança da planta. O reporte adequado das classificações auxilia na manutenção e aumenta a segurança da planta, por exemplo, evitando-se o transbordo de fluidos dos tanques. Espera-se predizer e classificar alguns dos problemas que afetam a medição de nível por radares e recomendar melhorias relatando-se os citados problemas de acordo com as diretrizes da norma internacional NAMUR NE107. Uma pesquisa foi realizada nas bases científicas a partir das palavras chave: diagnósticos, redes neurais ou support vector machines e medições de nível por radares e não foi encontrada uma pesquisa que utilizasse redes neurais, svm para diagnosticar problemas em medições de nível por radares, o que torna a presente tese inédita para a comunidade científica.

\subsection{Trabalhos desenvolvidos e estrutura do texto da Tese}

Durante o desenvolvimento da Tese, foram publicados artigos nos Congressos, IFAC TAS 2016 e INDUSCON 2016 de acordo com as citações a seguir:

$\square$ Borg, D.; Pinto, F. F.; Suetake, M.; Brandão, D. Neural networks as a diagnosing tool for industrial level measurement through non-contacting radar type. INTERNATIONAL FEDERATION OF AUTOMATIC CONTROL. IFAC SYMPOSIUM ON TElematics APPliCATiOn, 4. Porto Alegre, 2016. Anais... 2016.

$\square$ Borg, D.; Pinto, F. F.; Suetake, M.; Brandão, D. Aplicação de redes neurais para diagnósticos de medições industriais de nível. IEEE/IAS INTERNATIONAL CONFERENCE ON INDUSTRY APPLICATIONS, 12. Curitiba, 2016. Anais... 2016.

O texto dessa tese está estruturado em capítulos sendo que o capítulo 2 informa sobre os medidores industriais utilizados para a medição de nível, suas limitações e seu emprego, o princípio de funcionamento da tecnologia TDR-time domain reflectometry, e alguns esclarecimentos sobre as condições de processos pertinentes à medição de nível. Também relata sobre a pesquisa bibliográfica realizada e sobre as diretivas da norma internacional NAMUR NE107. 
O Capítulo 3 trata da rede neural e do support vector machine utilizados como classificadores.

Na sequência, no Capítulo 4 é explicado o desenvolvimento da técnica para a aplicação dos classificadores e como foram adquiridos os dados para os quatro cenários utilizados.

O Capítulo 5 mostra os resultados obtidos para os dois classificadores considerando-se os quatro cenários e finaliza com a discussão desses resultados.

Em seguida, encontra-se a conclusão da tese, as referências e os quatro apêndices que versam sobre o Toolkit, software para dimensionamento dos radares utilizados no Apêndice A, o guia de seleção do radar e antena no Apêndice B, as figuras em relação ao tempo no Apêndice $\mathrm{C}$ e o código de programação no Matlab e as telas principais do software Weka para o quarto cenário no Apêndice D tornando possível a reutilização desses procedimentos. 


\section{A medição de nível por radares}

A medição de nível é a determinação da posição de uma superfície dentro de um tanque, reator ou outro vaso. Pode se definir, de uma forma mais precisa, que a medição de nível é a determinação da distância vertical entre um ponto de referência e a superfície de um liquido, a parte superior de um sólido ou a interface entre dois líquidos.

O controle ou a indicação do nível é importante em muitas aplicações na indústria de processos. Uma das principais aplicações para a medição de nível é para inventário. Ou seja, a medição de nível é utilizada para se quantizar o volume ou o peso. Nesse caso a medição está relacionada à segurança, custo de armazenamento e valor do produto estocado. Uma aplicação muito importante é a transferência de custódia, onde a quantidade de material comprada ou vendida, tem como base a medição do nível convertida para volume ou peso, seja por meio de equacionamento matemático a partir da geometria do tanque ou através de tabelas de arqueamento (strapping tables). Para essas aplicações, usualmente uma precisão menor do que $3 \mathrm{~mm}$ na medição do nível é exigida. Há padrões internacionais como a API Manual of Petroleum Measurements (MPMS), capítulo 3.1B e OIML R85 que regimentam as aplicações de medição para compra e venda de produtos.

Outra aplicação comum é para se manter a eficiência de um determinado processo. Por exemplo, se um parque de tanques necessita manter uma quantidade de material disponível. Se a medição não estiver correta, gastos desnecessários poderão ocorrer para se fazer a logística não programada de compra e abastecimento dos tanques, ou ainda, para se manter tanques sobressalentes com estocagem de material desnecessário. A medição pode ser utilizada também por razões de segurança como para evitar espirros, transbordamento, ou vazamento de material tóxico, cáustico, inflamável, ou em temperaturas elevadas que podem ser perigosos para pessoas ou para o meio ambiente. Uma outra forma de utilização da medição de nível ocorre em aplicações onde é necessário um fluxo contínuo de produto em que a entrada, muitas vezes, não é contínua. Dessa forma um tanque pulmão pode ser a solução para que se mantenha uma saída numa taxa contínua mesmo que haja variações na taxa de entrada do tanque. Um exemplo de aplicação é a indústria de papel, na qual um fluxo consistente é necessário para se garantir a mesma gramatura na fabricação da 
folha de papel.

A medição do nível de um tanque pode ser indicada como uma medida associada da altura do liquido do tanque, como $9 \mathrm{~m}$, ou uma porcentagem, 90\% da faixa medida, ou ainda $50 \%$ considerando-se que essa faixa seja entre 8 e 10 metros como no exemplo da Figura 1.

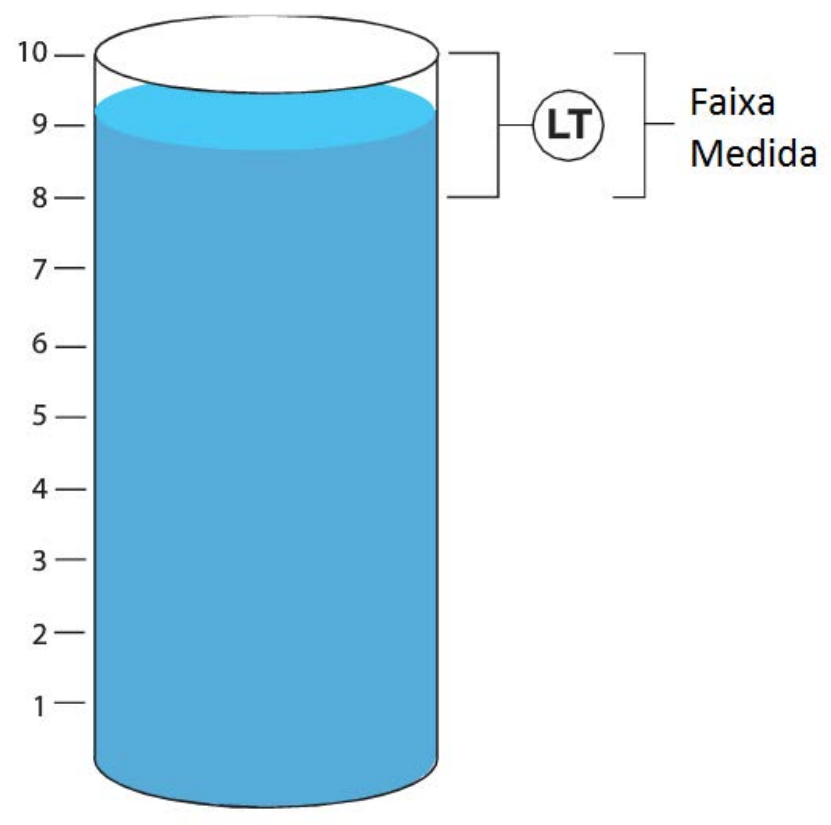

Figura 1 - Formas de se expressar a medição do nível. Fonte: Baseado em Rosemount (2013).

\subsection{Medidores de nível e suas limitações}

As medições de nível exatas e com repetibilidade em plantas industriais são historicamente difíceis de serem atingidas. Em plantas de processos como na indústria química, farmacêutica, refinaria de petróleo, geração de energia, papel e celulose necessitam medir nível em uma ampla variedade de produtos armazenados em suas fábricas. Esses materiais vão desde os inofensivos como água até os corrosivos como ácido hidroclorídrico. Os tanques que armazenam esses fluidos variam largamente em tamanho, forma e configuração. Algumas tecnologias utilizadas para a medição de nível nesses tanques incluem transmissores diferenciais de pressão, flotadores, ultrassônicos, medidor tipo capacitivo, entre outros. Nenhuma tecnologia é boa para todas as aplicações, embora existam aplicações em que muitas tecnologias diferentes podem ser aplicadas Rosemount (2013).

Os diversos tipos de tecnologia empregada nos medidores de nível tem suas limitações com relação às condições do processo. A Tabela 1 ilustra os principais medidores industriais de nível e sua relação com as mais comuns condições de processo. 
Tabela 1 - Visão geral sobre os medidores de nível e condições do processo. Fonte: Baseado em Rosemount (2013).

\begin{tabular}{|c|c|c|c|c|c|c|c|c|c|c|c|}
\hline $\begin{array}{l}\text { Condições do pro- } \\
\text { cesso }\end{array}$ & $\begin{array}{l}10 \\
0 \\
0 \\
0 \\
0 \\
0 \\
0\end{array}$ & 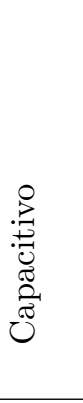 & 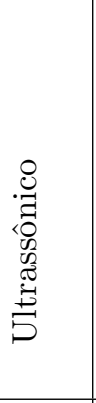 & 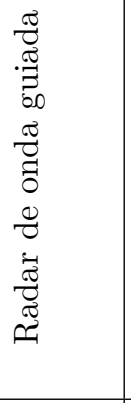 & 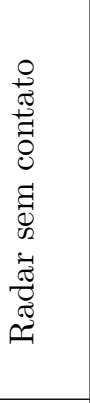 & 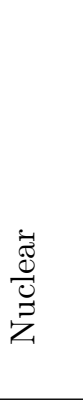 & 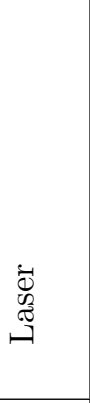 & 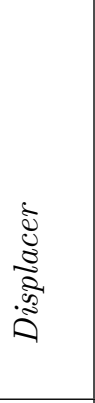 & 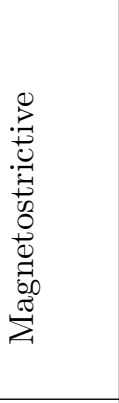 & 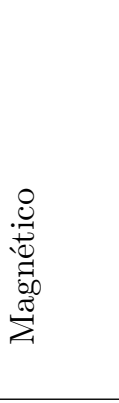 & $\begin{array}{l}P \\
\stackrel{0}{0} \\
\omega\end{array}$ \\
\hline Aeração & $\bmod$. & bom & mod. & bom & mod. & mod. & mod. & bom & mod. & bom & mod. \\
\hline Agitação & bom & mod. & ruim & ruim & bom & bom & mod. & bom & mod. & bom & mod. \\
\hline $\begin{array}{l}\text { Mudanças na tem- } \\
\text { peratura ambiente }\end{array}$ & mod. & bom & $\bmod$. & bom & bom & bom & bom & $\bmod$. & bom & bom & bom \\
\hline Corrosão & mod. & bom & bom & mod. & bom & bom & bom & mod. & mod. & $\bmod$. & $\bmod$. \\
\hline $\begin{array}{l}\text { Mudanças de densi- } \\
\text { dade }\end{array}$ & mod. & bom & bom & bom & bom & mod. & bom & mod. & mod. & mod. & ruim \\
\hline $\begin{array}{l}\text { Variação da cte di- } \\
\text { elétrica }\end{array}$ & bom & ruim & bom & bom* & bom & bom & bom & bom & bom & bom & bom \\
\hline Poeira & bom & bom & ruim & bom & mod. & bom & ruim & ruim & bom & ruim & ruim \\
\hline Emulsão & bom & bom & bom & mod.** & bom & bom & bom & bom & $\bmod . * *$ & $\bmod . * *$ & $\bmod . * *$ \\
\hline Espuma & bom & mod. & ruim & bom & mod. & bom & ruim & bom & bom & bom & mod. \\
\hline $\begin{array}{l}\text { Alta temperatura } \\
\text { do processo }\end{array}$ & bom & bom & ruim & bom & mod. & bom & bom & bom & ruim & bom & mod. \\
\hline $\begin{array}{l}\text { Alta pressão do re- } \\
\text { cipiente }\end{array}$ & bom & bom & ruim & bom & mod. & bom & bom & bom & ruim & mod. & mod. \\
\hline $\begin{array}{l}\text { Obstruções inter- } \\
\text { nas }\end{array}$ & bom & mod. & mod. & mod. & mod. & mod. & mod. & bom & bom & bom & bom \\
\hline $\begin{array}{l}\text { Baixas temperatu- } \\
\text { ras do processo }(<- \\
\left.40{ }^{\circ} \mathrm{C}\right)\end{array}$ & bom & bom & bom & bom & bom & bom & bom & mod. & bom & mod. & bom \\
\hline $\begin{array}{l}\text { Baixa pressão do } \\
\text { processo (vácuo) }\end{array}$ & mod. & bom & ruim & bom & bom & bom & bom & bom & bom & bom & bom \\
\hline $\begin{array}{l}\text { Ruído (EMI, moto- } \\
\text { res...) }\end{array}$ & bom & bom & mod. & bom & bom & mod. & bom & bom & bom & bom & bom \\
\hline $\begin{array}{l}\text { Produto que tende } \\
\text { a colar }\end{array}$ & ruim & ruim & mod. & $\bmod$. & bom & mod. & $\bmod$. & ruim & ruim & ruim & ruim \\
\hline Lamas & mod. & bom & bom & $\bmod$. & bom & bom & bom & ruim & $\bmod$. & $\bmod$. & ruim \\
\hline Sólidos & ruim & mod. & mod. & bom & bom & bom & bom & ruim & ruim & ruim & ruim \\
\hline Vapores & bom & mod. & ruim & bom & mod. & bom & ruim & bom & bom & bom & $\bmod$. \\
\hline Produtos viscosos & mod. & mod. & bom & mod. & bom & bom & bom & ruim & ruim & ruim & ruim \\
\hline
\end{tabular}

Bom. Essa condição tem mínima ou nenhuma influência para a medição de nível. Mod. (Moderado). Pode funcionar, mas o desempenho será prejudicado ou uma instalação especial é necessária.

Ruim. Essa tecnologia não se aplica à essa condição.

* Alterações na constante dielétrica impactarão na incerteza da medição da interface. ** Bom para medições gerais de nível e moderado para medições de interface.

A Tabela 2 elucida sobre os limites máximos e mínimos de pressão e de temperatura 
para alguns medidores de nível na indústria.

Tabela 2 - Limites de pressão e temperatura dos medidores de vazão. Fonte: Baseado em Rosemount (2013).

\begin{tabular}{|lcr|}
\hline Tecnologia & \multicolumn{1}{c}{ Pressão } & Temperatura \\
\hline Capacitância & $-14,7$ até $5000 \mathrm{psig}$ & -129 a $482{ }^{\circ} \mathrm{C}$ \\
\hline Displacer & $-14,7$ até $4000 \mathrm{psig}$ & -40 a $482{ }^{\circ} \mathrm{C}$ \\
\hline Pressão & $-14,7$ até $4000 \mathrm{psig}$ & -40 a $193{ }^{\circ} \mathrm{C}$ \\
\hline Pressão com selos remotos & $-14,7$ até $4000 \mathrm{psig}$ & -73 a $316{ }^{\circ} \mathrm{C}^{* * *}$ \\
\hline Ultrassônico & $-3,6$ até $44 \mathrm{psig}$ & -30 a $70{ }^{\circ} \mathrm{C}$ \\
\hline Radar sem contato & $-14,7$ até $798 \mathrm{psig}$ & -40 a $400{ }^{\circ} \mathrm{C}$ \\
\hline Radar com guia de onda & $-14,7$ até $5000 \mathrm{psig}$ & -196 a $400{ }^{\circ} \mathrm{C}$ \\
\hline
\end{tabular}

*** A temperatura superior para selos remotos é limitada quando em aplicações com vácuo.

\section{Comparação entre o radar e outras tecnologias de medição de nível}

Cada uma das tecnologias tem suas limitações em virtude dos diferentes ambientes encontrados nas diferentes indústrias de processo. Os transmissores de pressão são afetados por alterações de pressão dentro do tanque ou por alterações na densidade do produto. Os medidores tipo flotadores são afetados por fluidos muito viscosos ou corrosivos. Alterações nos valores de pressão, temperatura ou no vapor dentro do tanque causam imprecisão na medição dos medidores ultrassônicos. As sondas dos medidores capacitivos são difíceis de calibrar e são sensíveis às mudanças da constante dielétrica do fluido dentro do tanque. O radar sem contato é uma solução com boa relação custo benefício, que não entra em contato com o fluido do processo, não é afetado por fatores ambientais como variação da densidade, da pressão ou da temperatura dentro do tanque.

\subsection{A tecnologia TDR}

Essa seção informa sobre o princípio de funcionamento dos radares que empregam a tecnologia TDR, alguns detalhes do radar utilizado para o experimento do primeiro cenário, a pesquisa bibliográfica e a configuração dos ajustes avançados para uma melhor medição de nível com o radar.

Em Nemarich (2001) é explicada a origem da tecnologia TDR.

$\mathrm{O}$ artigo descreve como a tecnologia TDR funciona com um guia de onda. O instrumento descrito é um radar com o guia de onda que se prolonga para dentro do tanque. Essa mesma tecnologia é utilizada para o funcionamento de radares de onda livre com a diferença de que nos radares com o guia de onda, parte dessa entra em contato com o fluido do processo e nos de onda livre, a antena irradia os pulsos e recebe os ecos, porém não entra em contato direto com o fluido. 
A técnica de reflectometria no domínio do tempo (do inglês TDR - time domain reflectometry) tem sido utilizada por engenheiros eletricistas desde a década de 1930 para verificação das características das linhas de transmissão e diagnóstico de falhas. As linhas de transmissão são utilizadas para transmitir energia e sinais de um ponto a outro. A transmissão básica conecta uma fonte a uma carga Hayt (1995) e Sartori (1999) . É importante que a energia seja transmitida com um mínimo de atenuação, sendo as perdas por calor ou radiação as menores possíveis Kraus (1983).

Muitas aplicações exigem a medição do nível da interface entre mais de um líquido. Requisitos rigorosos estabelecidos pelas indústrias de controle de processo e refinarias para controle de estoque ou para a liberação de fluidos contaminados com petróleo obrigam os usuários a optar por múltiplas tecnologias de sensores de nível em um único tanque. No entanto, em muitos casos, um sensor de nível TDR poderia ser usado para determinar com precisão vários níveis de fluido e interfaces com uma única sonda.

A tecnologia TDR é uma técnica de amostragem de pulsos que caracterizam as propriedades elétricas distribuídas nas linhas de transmissão. Instrumentos TDR enviam pulsos de baixa amplitude e alta frequência em uma linha de transmissão, cabo, ou guia de ondas que está em teste e, em seguida, amostra sequencialmente as amplitudes do sinal refletido. Tipicamente, as amplitudes dos pulso refletidos são exibidas em uma escala de tempo calibrada. Desta forma, mudanças de impedância do cabo e descontinuidades podem ser espacialmente localizadas e avaliadas. Cabos de transmissão, usados para propagar a energia eletromagnética variável no tempo, se comportam como circuitos distribuídos ao invés de um único elemento. Para fins de avaliação, as linhas de transmissão podem ser representadas como uma série de elementos de circuitos. Um cabo coaxial pode ser modelado como uma linha de transmissão ideal, sem perdas e desequilibrada como mostrado na Figura 2. A impedância de surto, a velocidade de propagação do pulso e o coeficiente de reflexão determinam a relação tensão-corrente de um sinal variante no tempo ao longo do cabo coaxial. A impedância de surto, $Z_{0}$, é dada como a raiz quadrada da relação entre a indutância e capacitância por unidade de comprimento conforme ilustra a Equação 1.

$$
Z_{0}=\sqrt{\frac{L}{C}}
$$

$Z$ é medida em ohms, $L$ em Henrys e $C$ em Faradays.

No caso sem perdas, a impedância é puramente resistiva. Modelos mais sofisticados levam em consideração a reatância. A velocidade de propagação de impulsos, v, é dado como o inverso da raiz quadrada da capacitância pela indutância por unidade de comprimento como ilustrado na Equação 2.

$$
v=\frac{1}{\sqrt{L C}}
$$


Qualquer alteração das propriedades físicas de uma linha de transmissão irá alterar a sua impedância característica. Sinais eletromagnéticos viajando ao longo da linha de transmissão terão parte ou toda a sua energia refletida devido à descontinuidade da impedância. Por exemplo, se um cabo coaxial uniforme possui uma terminação com uma carga $Z_{T}$, parte ou todos os pulsos eletromagnéticos viajando ao longo do cabo coaxial serão refletidos neste terminal. A amplitude e polaridade da energia refletida é determinada pelo coeficiente de reflexão da onda de tensão, $\rho$, que é expressa como:

$$
\rho=\frac{Z_{T}-Z_{0}}{Z_{T}+Z_{0}}
$$

onde $Z_{T}$ é a terminação ou a impedância de carga.

Conhecendo esses parâmetros, pode-se prever, aproximadamente, a amplitude da tensão e corrente de um pulso em qualquer localização ao longo do cabo coaxial para qualquer período de tempo. Na sua forma mais simples, um TDR consiste num gerador de pulsos e um amostrador de pulsos conforme mostrado na Figura 3 .

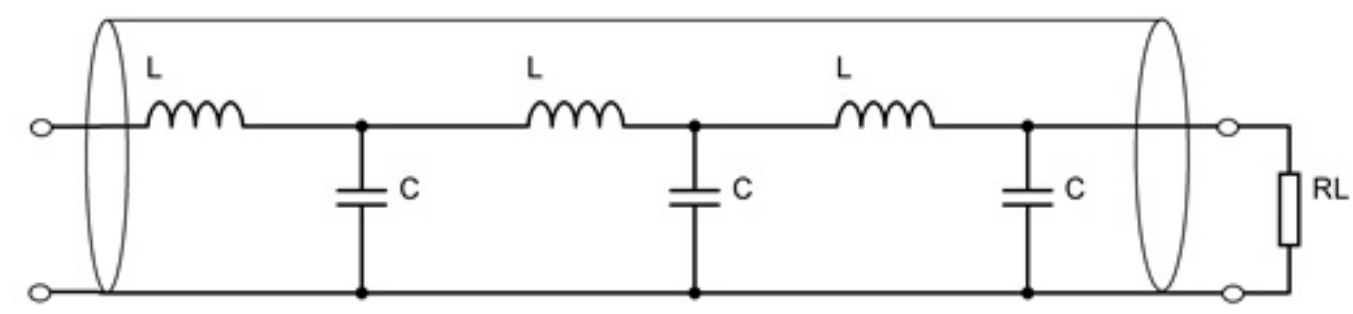

Figura 2 - Modelo de uma linha de transmissão. Fonte: Baseado em Nemarich (2001).

Neste exemplo, o TDR é ligado a uma linha de transmissão constituída por dois segmentos de cabos coaxiais em série com um resistor de carga $R_{t}$ acoplado na terminação. O primeiro segmento de cabo coaxial tem impedância $Z_{1}$ dada pela capacitância e indutância em uma unidade de comprimento, $C_{1}$ e $L_{1}$, respectivamente. O segundo segmento de cabo coaxial tem uma impedância, $Z_{2}$ dada pela capacitância e indutância em uma unidade de comprimento, $C_{2}$ e $L_{2}$. Supondo $R_{S}=Z_{1}=50 \Omega, Z_{2}=75 \Omega$, e $R_{t}=100$ $\Omega$. A Figura 3 ilustra o que acontece quando o TDR envia um pulso para esta linha de transmissão.

Em $t_{0}$, o pulso começa a viajar ao longo do segmento 1 , com tensão $V_{1}$ e velocidade de propagação $v_{1}$. Quando o pulso atinge a junção com o segmento coaxial 2, um pulso com amplitude $V_{2}$ irá continuar a propagar-se no segmento coaxial 2 mas com uma nova velocidade, $v_{2}$. Ao mesmo tempo, um pulso com amplitude $V_{3}$ é refletido ao longo do segmento 1 em direção ao circuito de amostragem. A amplitude dos pulsos transmitidos e refletidos é calculada com o coeficiente de reflexão $\rho_{12}$. O pulso refletido chega ao circuito de amostragem em $t_{1}$. O pulso $V_{3}$ continua viajando ao longo do segmento 2 até 


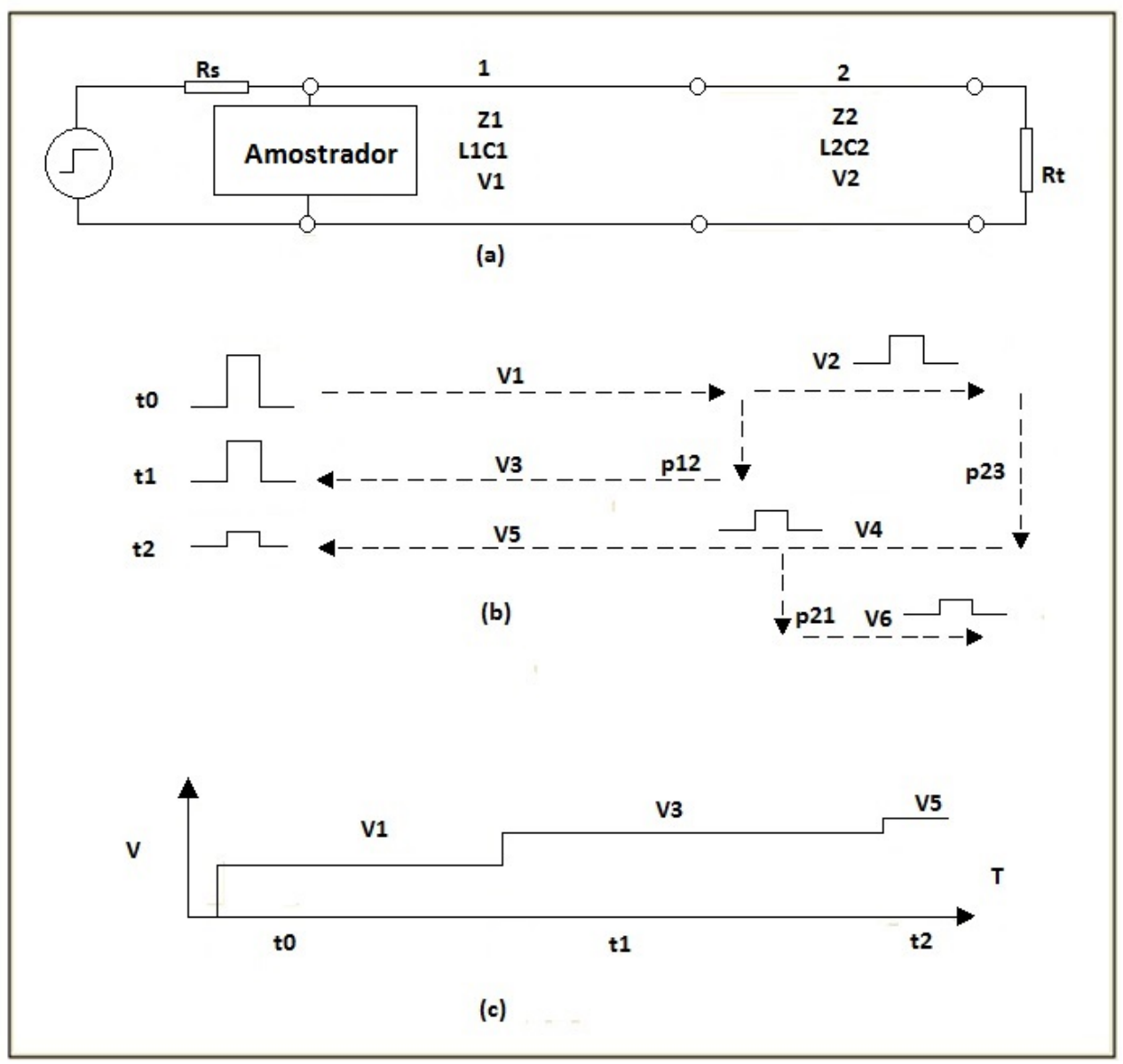

Figura 3 - (a) TDR e dois segmentos coaxiais; (b) Diagrama de reflexão do pulso; (c) Traço idealizado de um TDR no osciloscópio. Fonte: Baseado em Nemarich (2001).

atingir a resistência na terminação, onde é refletido. O pulso refletido possui amplitude $V_{4}$ determinada através do coeficiente de reflexão $\rho_{23}$. Este pulso se propaga ao longo do segmento 2 até atingir a junção com o segmento 1. Mais uma vez, uma parte do pulso continua a percorrer a linha em direção ao circuito de amostragem chegando em $t_{2}$ e uma porção reflete de volta para a terminação. Estes pulsos são mostrados como $V_{5}$ e $V_{6}$. As amplitudes são determinadas pelo coeficiente de reflexão $\rho_{21}$. Os valores de tensão e de tempo pode ser calculados pela utilização das seguintes relações expressa nas Equações 4 a 10:

$$
\begin{gathered}
\rho_{12}=\frac{Z_{2}-Z_{1}}{Z_{2}+Z_{1}}=\frac{75-50}{75+50}=0,2 \\
\rho_{23}=\frac{R_{L}-Z_{2}}{R_{L}+Z_{2}}=\frac{100-75}{100+75}=0,1429 \\
\rho_{21}=\frac{Z_{1}-Z_{2}}{Z_{1}+Z_{2}}=\frac{50-75}{50+75}=-0,2
\end{gathered}
$$




$$
\begin{gathered}
V_{2}=\rho_{12} V_{1}+V_{1}=1,2 V_{1} \\
V_{3}=\rho_{12} V_{1}=0,2 V_{1} \\
V_{4}=\rho_{23} V_{2}=0,14 V_{2}=0,17 V_{1} \\
V_{5}=\rho_{23} V_{4}+V_{4}=-0,2(0,17)+0,17=0,136
\end{gathered}
$$

A Figura 3(c) mostra o gráfico ideal da saída do amostrador.

Em $t_{1}$, o pulso $V_{3}$ tem amplitude de $0,2 \mathrm{~V}$. Este pulso é sobreposto no sinal inicial para aumentar a amplitude do sinal em $0,2 \mathrm{~V}$. Em $t_{2}$, o pulso $V_{5}$ retorna para o amostrador e aumenta em $0,136 \mathrm{~V}$ o sinal. O sincronismo dos sinais é calculado pela relação de duas vezes o comprimento do segmento do cabo dividido pela velocidade de propagação como indicado nas Equações 11 e 12:

$$
\begin{gathered}
t_{1}=\frac{2 *(\text { comprimento do segmento } 1)}{v_{1}} \\
t_{2}-t_{1}=\frac{2 *(\text { comprimento do segmento } 2)}{v_{2}}
\end{gathered}
$$

\subsection{Medindo nível por TDR}

Por meio do TDR pode-se medir o nível de líquidos e sólidos em um tanque. Para a medição o TDR se conecta à uma sonda de nível inserida dentro do tanque. As primeiras aplicações patenteadas de medição de nível através do TDR foram propostas na década de 1960. Na década de 1980, engenheiros da marinha dos Estados Unidos no Centro de pesquisa David Taylor em Annapolis, MD, desenvolveram um sistema TDR para a medição de nível de óleo em tanques de combustíveis compensados com água do mar em navios de guerra da marinha americana. Um sistema completamente funcional demonstrou com sucesso o conceito a bordo de um destroyer da marinha no final da década de 1980. Atualmente, várias empresas disponibilizam comercialmente os sensores de nível TDR.

A Figura 5 mostra um sensor de nível de fluido TDR. A sonda de nível atua como uma linha de transmissão aberta; ela pode ser um tubo, hastes de metal, cabos de metal ou qualquer outra configuração que consiga atuar como uma linha de transmissão uniforme para o envio de pulsos. O conteúdo do tanque se torna o isolamento dielétrico da linha de transmissão. Em cada interface entre fluidos, uma mudança na constante dielétrica do líquido em torno da sonda resulta em uma mudança na impedância que reflete uma 
parte do pulso para o receptor do TDR. A amplitude e o tempo de propagação do pulso podem ser utilizados para se determinar precisamente o nível do fluído e a localização da interface de cada fluído dentro do tanque. A verificação é feita da seguinte maneira: Para sondas coaxiais, a impedância característica pode ser calculada pela Equação 13 Nemarich (2001):

$$
Z_{0}=\frac{138 \log \left(\frac{b}{a}\right)}{\sqrt{\frac{\epsilon_{r}}{\mu_{r}}}}
$$

sendo:

$a=$ diâmetro do condutor central (Figura 4);

$b=$ diâmetro interno do condutor externo (Figura 4);

$\epsilon_{r}=$ permissividade relativa (dielétrico) do material de isolamento que separa os condutores;

$\mu_{r}=$ permeabilidade relativa do material que separa os condutores.

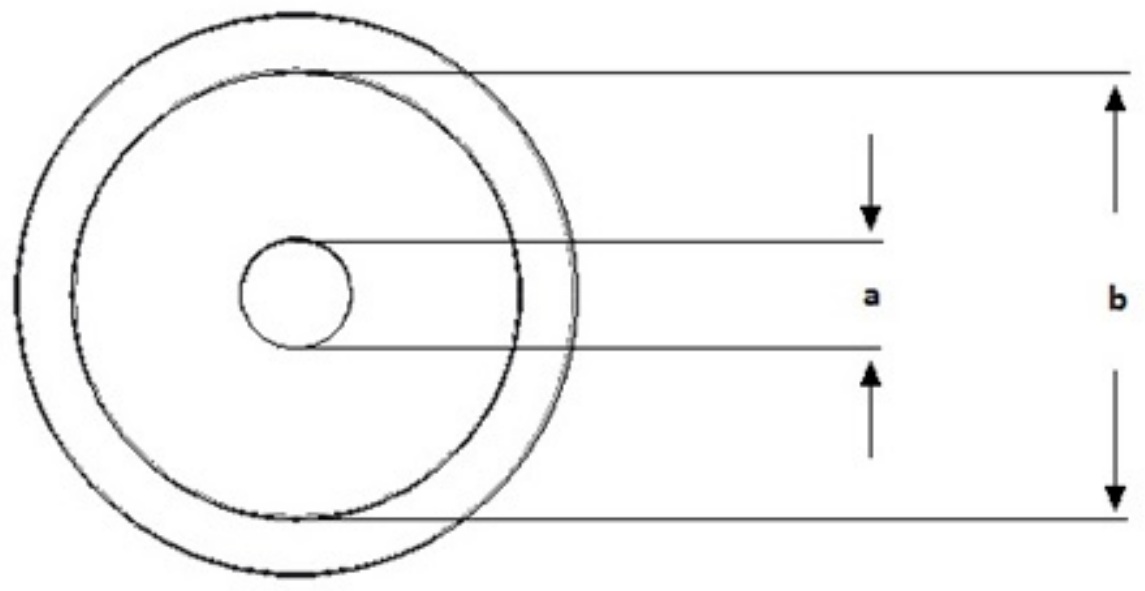

Figura 4 - Seção coaxial de uma antena. Fonte: Baseado em Nemarich (2001).

A capacitância e a indutância por unidade de comprimento são dadas pela Equação 14 e Equação 15 Nemarich (2001):

$$
\begin{aligned}
& C=\frac{2 \pi \epsilon}{\ln \left(\frac{b}{a}\right)} \\
& L=\frac{\frac{\mu}{2 \pi}}{\ln \left(\frac{b}{a}\right)}
\end{aligned}
$$

Ao substituir os termos das equações e fatorar $\mu$, a impedância característica da sonda pode ser expressa em termos da constante dielétrica do meio no qual se encontra a sonda. Isso está explicitado na Equação 16 com $\alpha$ indicando proporcionalidade:

$$
Z_{f} \alpha \frac{1}{\sqrt{\epsilon_{f}}}
$$


Esta expressão para impedância pode ser substituída no coeficiente de pulso de reflexão, $\rho$, e relacionar com a amplitude do pulso refletido. É importante ressaltar que a velocidade de propagação do pulso é inversamente proporcional à capacitância e também pode ser expressa em termos da constante dielétrica. A equação para o sincronismo entre os pulsos refletidos pode ser simplificada como indicado na Equação 17:

$$
\rho_{t} \alpha L_{f} \sqrt{\epsilon_{f}}
$$

onde $\rho_{t}$ é o tempo entre os pulsos refletidos nas interfaces do fluido e $L_{f}$ é o comprimento do fluido ao longo da sonda.

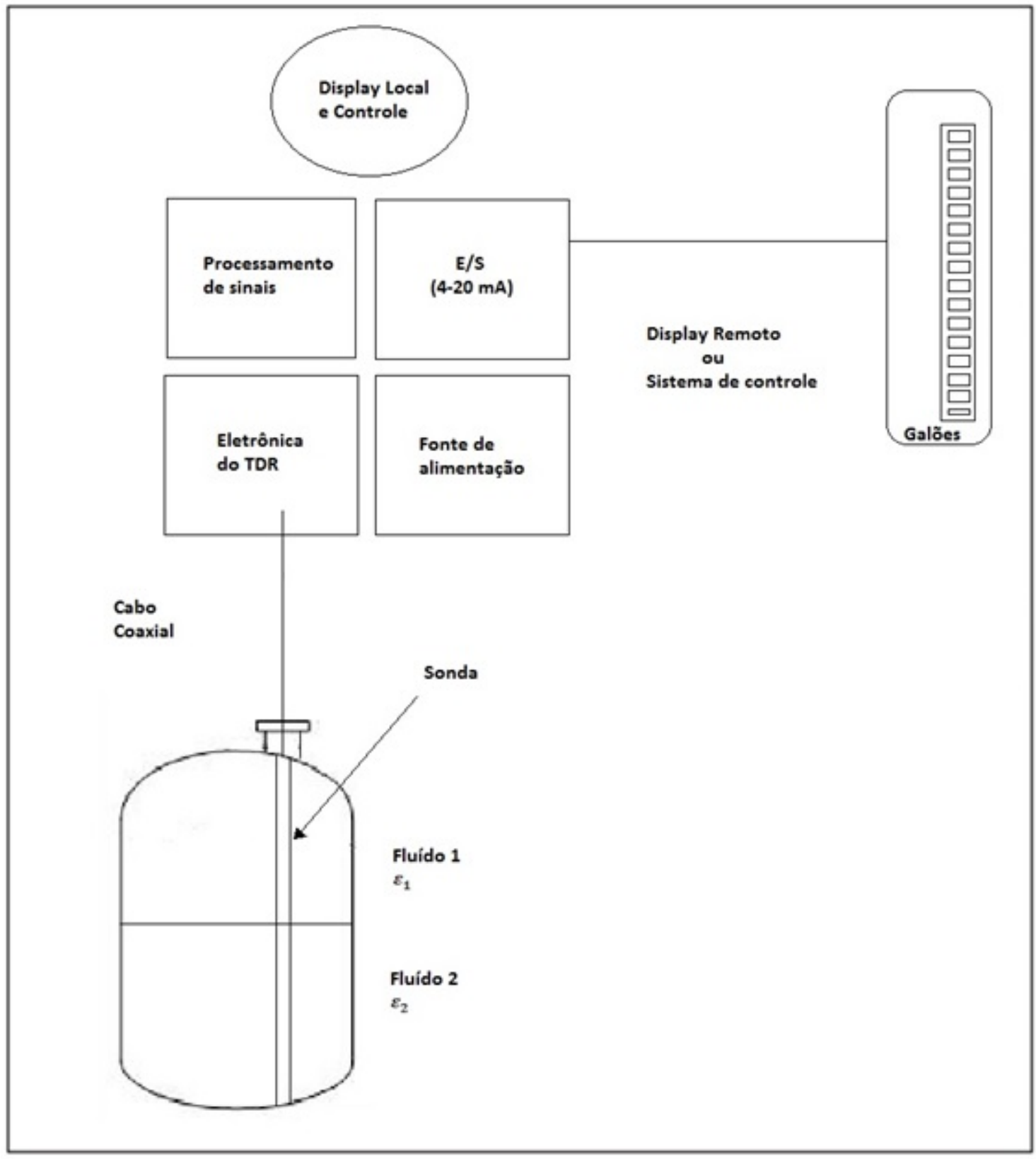

Figura 5 - Sensor TDR de nível de fluido. Fonte: Baseado em Nemarich (2001). 
Algumas vantagens do sensor de nível TDR incluem:

- Montagem simples;

- Sem partes móveis, com a antena no tanque livre de manutenção;

- Alta resolução;

- Capacidade de medir interface de múltiplos fluidos;

- Facilidade de reparação;

- Habilidade para lidar com tanques que possuem geometrias complexas;

- Intrinsecamente seguro;

Além disso, sensores de nível TDR possuem um material da antena que pode ser selecionado para resistir à corrosão ou esta pode ser revestida para evitar os problemas de corrosão.

\subsection{Exemplos das principais aplicações com radares sem contato}

As principais aplicações dos radares sem contato são tanques com superfície calma, detecção de transbordo, fluidos corrosivos, pegajosos ou cristalizantes, fluidos com lama ou lodo e reatores. Os próximos parágrafos ilustram algumas dessas aplicações.

Os radares sem contato podem ser utilizados em aplicações menos exigentes, tais como tanques de armazenamento ou tanques pulmão. Eles são fáceis de montar devido à sua instalação na parte superior do tanque, são livres de manutenção e apresentam alta precisão na medição de nível. São muito utilizados em monitoramentos precisos e no controle de processos.

Os radares podem ser empregados em aplicações para redução de risco dos sistemas. A medição contínua pode reduzir ou simplificar os testes (proof-tests). Além disso, múltiplos radares podem ser utilizados no mesmo tanque.

A medição por radar é ideal para a maioria dos produtos corrosivos, tais como cáusticos e ácidos, solventes, e muitos outros produtos químicos. O instrumento não entra em contato com o produto do processo. Existe uma ampla oferta de materiais da antena ou revestimentos como PTFE, alloy C-276 e alloy 400. Além disso, os radares sem contato funcionam bem em aplicações com tanques não-metálicos.

Os intrumentos sem contato são os melhores para esse tipo de aplicação fornecendo uma leitura confiável com produtos difíceis de medir como resinas e adesivos. Há antenas especialmente projetadas para evitar condensação de vapores e deposição de materiais.

Aplicações como lama, polpas e as lamas de cal podem ser trabalhadas com radares sem contato por serem praticamente imunes à respingos e conteúdo de sólidos. Também 
não são afetados por mudanças na densidade do fluido, não requerem recalibração e necessitam de pouca ou nenhuma manutenção. Rosemount (2014).

O projeto do radar sem contato, o torna uma escolha para as aplicações mais difíceis, tais como os reatores, como indicado na Figura 6, devido à utilização da polarização circular que proporciona maior flexibilidade na montagem, ou seja, não é necessária uma distância mínima da parede do tanque. Outra vantagem é a medição direta que torna a medição independente da maioria das variações na condições do processo, tais como densidade, constante dielétrica, vapor, temperatura e pressão. E ainda, pode lidar com condições turbulentas criadas por agitação, enchimento do fluido na parte superior do tanque, ou reação do processo.

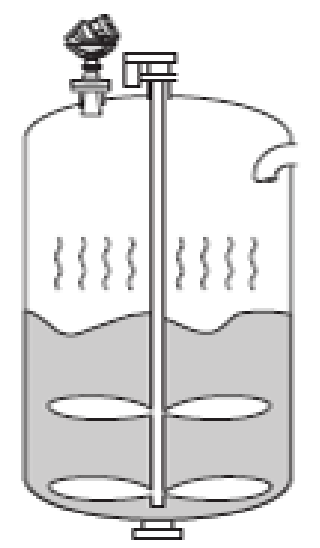

Figura 6 - Aplicações de radares sem contato em reatores. Fonte: Rosemount (2014).

A montagem do radar pode ser utilizada não somente em flanges padronizados. Ele se encaixa na maioria dos tubos existentes de 2 a 8 polegadas (50 a $200 \mathrm{~mm}$ ) de diâmetro. Pode ser facilmente isolado do processo usando-se uma válvula isoladora conforme ilustrado na Figura 7. Tubos acalmadores reduzem a influência da espuma, turbulência e obstruções internas do tanque.

A montagem na parte superior do tanque, a facilidade de montagem em flanges com diâmetros estreitos de até $2 \mathrm{~m}$ de comprimento, desde que estejam limpos e lisos. O fato de não ser afetado por produtos sujos com resíduos sólidos, tornam o radar sem contato um dos instrumentos ideais para aplicaçoes em tanques subterrâneos como ilustrado na Figura 8.

Algumas formas de interface com o radar utilizado são o uso de um indicador de campo, um comunicador de campo ou um computador com o software RRM. O radar ainda pode ser configurado com o software de gerenciamento de ativos como ilustrado na Figura 9. 


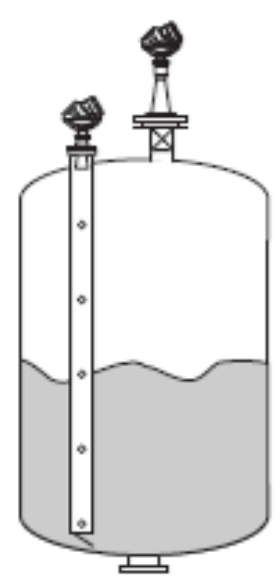

Figura 7 - Flexibilidade de instalação em flanges de 2 a 8 polegadas ou em válvulas isoladoras. Fonte: Rosemount (2014).

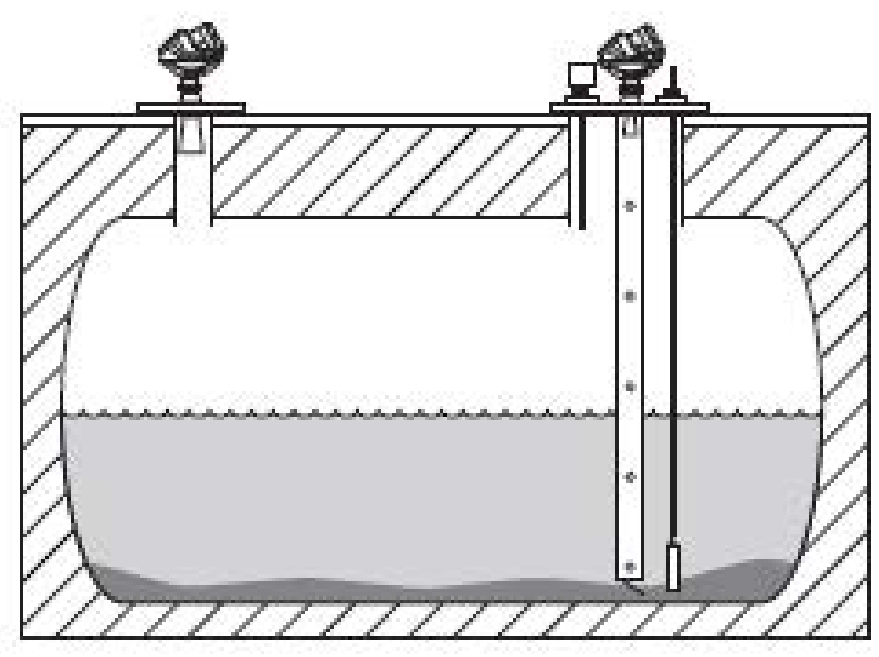

Figura 8 - Tanques subterrâneos. Fonte: Rosemount (2014).

\subsection{Características do processo}

Algumas características do processo como presença de espuma, turbulência, condensação do fluido na antena, e medição de sólidos podem trazer desafios à medição de nível enquanto outras características como variação de temperatura, pressão e de densidade do fluido do processo não apresentam impactos negativos para medições que empregam os radares sem contato. A seguir algumas recomendações são feitas quanto às características que podem provocar algum problema na medição.

Um parâmetro chave para o desempenho de medição é reflectividade. Uma elevada constante dielétrica do meio proporciona uma melhor reflexão e permite um maior alcance de medição de nível.

O radar pode ser utilizado em aplicações com espuma dependendo das propriedades 


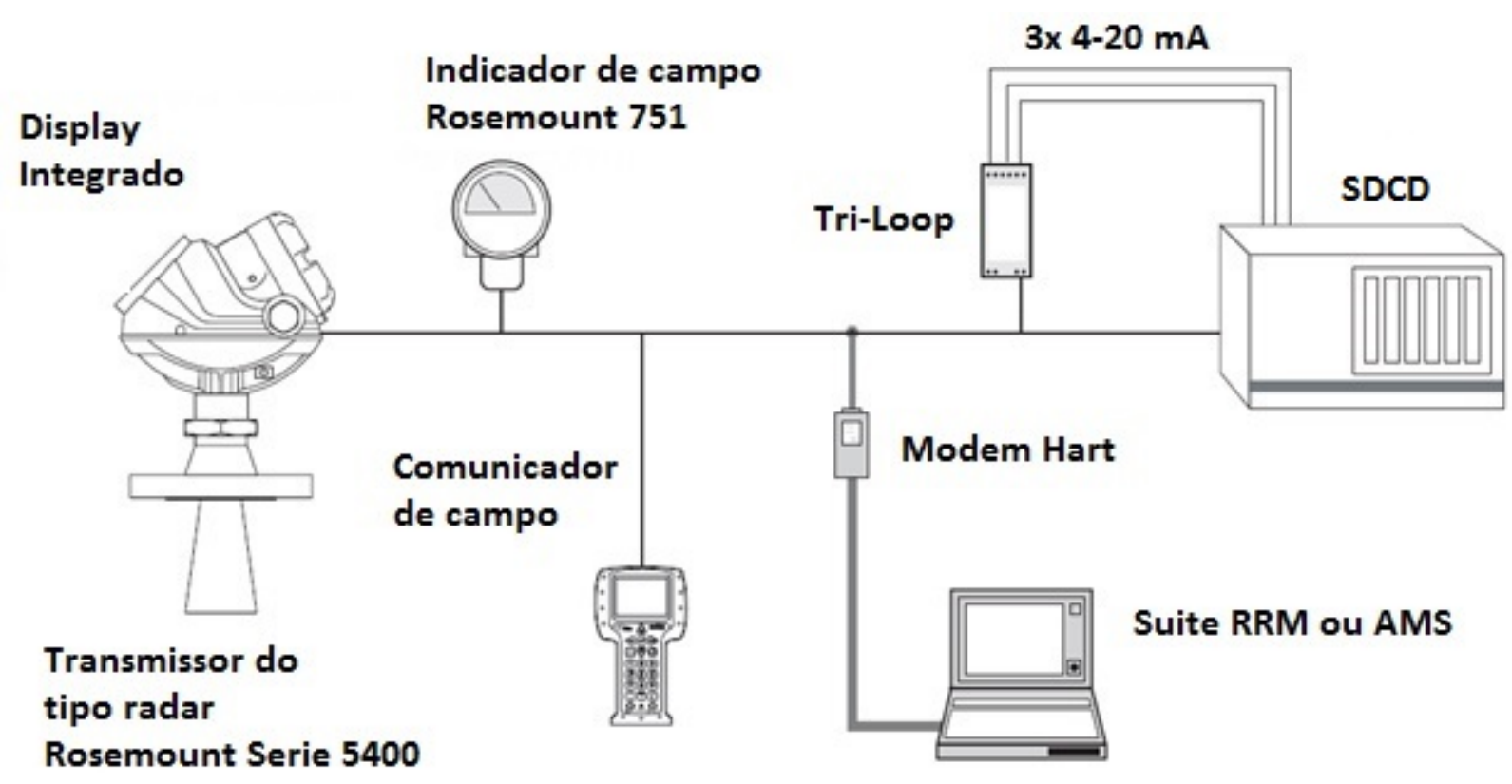

Figura 9 - Esquema de interligação do radar. Fonte: Baseado em Rosemount (2014).

da espuma; leves e aeradas ou densas e compactas, com constantes dielétricas altas ou baixas. Se a espuma é condutora, o transmissor tende a medir a superfície da espuma. Se a espuma for menos condutora, as micro-ondas podem penetrar na espuma e medir a superfície do líquido.

Uma superfície calma dá uma melhor reflexão do que uma superfície turbulenta. Para aplicações com turbulência, o alcance máximo do radar é reduzido. A faixa de medição depende principalmente da freqüência, do tamanho da antena, do dielétrico do material, e do grau de turbulência.

A superfície de materiais sólidos é raramente plana ou horizontal. O ângulo de repouso, ou superfície de inclinação, vai mudar conforme o enchimento ou esvaziamento do tanque. Muitas vezes existe uma grande quantidade de poeira durante o ciclo de enchimento. O valor da constante dielétrica de muitos sólidos é bastante baixa. Na sequência, os principais componentes do radar são ilustrados Rosemount (2014).

\subsection{Dimensionamento do radar}

Durante a fase de dimensionamento do radar, algumas características como a frequência de operação das micro-ondas, o tamanho da antena, a constante dielétrica $\varepsilon_{r}$ do líquido e as condições do processo devem ser levadas em conta para avaliar se a altura total desejada pelo usuário é possível de ser alcançada. Nessa seção são mostradas algumas dessas condições e direcionamentos para esse dimensionamento. No Apêndice A, um passo a passo do software Toolkit, um dos softwares utilizados na montagem do modelo 
de radares, está disponível.

Um valor maior da constante dielétrica do fluido produz uma reflexão mais forte do sinal do eco para o radar. Os números nas tabelas abaixo são uma diretriz para um bom desempenho do instrumento de medição de nível.

Valores típicos de constantes dielétricas:

a) Fluidos como óleo, gasolina ou outros hidrocarbonetos $\left(\varepsilon_{r}=1,9-4,0\right)$. Alguns gases liquefeitos $\left(\varepsilon_{r}=1,4-4,0\right)$;

b) Os álcoois, ácidos concentrados, solventes orgânicos, misturas de óleo / água, e acetona $\left(\varepsilon_{r}=4,0-10,0\right)$;

c) líquidos condutores, por exemplo soluções à base de água, ácidos diluídos e álcalis $\left(\varepsilon_{r}>10,0\right)$.

Na Tabela 3 e na Tabela 4 é possível observar um guia para os limites de medição dos radares de baixa $(6 \mathrm{GHz})$ e alta frequência $(26 \mathrm{GHz})$.

Tabela 3 - Faixa máxima de medição para o radar de alta frequência em pés (metros). Fonte: Baseado em Rosemount (2014).

\begin{tabular}{|c|c|c|c|c|c|c|c|c|c|}
\hline \multirow{2}{*}{$\begin{array}{l}\text { Antenas para } \\
\text { radares de alta } \\
\text { frequência }\end{array}$} & & & & & \\
\hline & & & & & & & & & \\
\hline \multicolumn{10}{|c|}{ Constante dielétrica } \\
\hline & $\mathrm{A}$ & $\mathrm{B}$ & $\mathrm{C}$ & $\mathrm{A}$ & $\mathrm{B}$ & $\mathrm{C}$ & $\mathrm{A}$ & B & $\mathrm{C}$ \\
\hline $\begin{array}{lr}\text { Antena } & \text { tipo } \\
\text { Cone / selo do } \\
\text { processo de } 2 \\
\text { polegadas }\end{array}$ & $33(10)$ & $49(15)$ & $66(20)$ & $82(25)$ & $115(35)$ & $115(35)$ & $9.8(3)$ & $20(6)$ & $33(10)$ \\
\hline $\begin{array}{lr}\text { Antena } & \text { tipo } \\
\text { Cone / selo do } \\
\text { processo de } 3 \\
\text { polegadas }\end{array}$ & $49(15)$ & $65(20)$ & $98(30)$ & $82(25)$ & $115(35)$ & $115(35)$ & $13(4)$ & $30(9)$ & $39(12)$ \\
\hline $\begin{array}{ll}\text { Antena } & \text { tipo } \\
\text { Cone / selo do } \\
\text { processo de } 4 \\
\text { polegadas }\end{array}$ & $65(20)$ & $82(25)$ & $115(35)$ & $82(25)$ & $115(35)$ & $115(35)$ & $23(7)$ & $39(12)$ & $49(15)$ \\
\hline
\end{tabular}

No Apêndice B há uma tabela que serve como guia para a seleção de modelos e antenas de radares.

É recomendado que o radar seja montado com o mínimo de estruturas internas quanto possível dentro do ângulo do feixe. Na Figura 10 é ilustrada a diferença de abertura dos feixes das micro-ondas.

A resistência máxima de carga $(R)$ é determinada pelo nível de tensão da fonte de alimentação externa $\left(U_{E}\right)$. O gráfico da Figura 11 ilustra o limite de carga para aplicações em áreas não classificadas Rosemount (2014). 
Tabela 4 - Faixa máxima de medição para o radar de baixa frequência em pés (metros). Fonte: Baseado em Rosemount (2014).

\begin{tabular}{|c|c|c|c|c|c|c|c|c|c|}
\hline \multirow{2}{*}{$\begin{array}{l} \\
\text { Antenas para } \\
\text { radares de baixa } \\
\text { frequência. }\end{array}$} & & & \\
\hline & & & & & & & & & \\
\hline \multicolumn{10}{|c|}{ Constante dielétrica } \\
\hline & $\mathrm{A}$ & $\mathrm{B}$ & $\mathrm{C}$ & $\mathrm{A}$ & $\mathrm{B}$ & $\mathrm{C}$ & $\mathrm{A}$ & $\mathrm{B}$ & $\mathrm{C}$ \\
\hline $\begin{array}{lr}\text { Antena } & \text { tipo } \\
\text { Cone de } & 3 \\
\text { polegadas } & \\
\end{array}$ & $\mathrm{NA}$ & NA & NA & $82(25)$ & $115(35)$ & $115(35)$ & NA & NA & NA \\
\hline $\begin{array}{lr}\text { Antena } & \text { tipo } \\
\text { Cone de } & 4 \\
\text { polegadas } & \\
\end{array}$ & $23(7)$ & $39(12)$ & $49(15)$ & $82(25)$ & $115(35)$ & $115(35)$ & $13(4)$ & $26(8)$ & $39(12)$ \\
\hline $\begin{array}{lr}\text { Antena } & \text { tipo } \\
\text { Cone de } & 6 \\
\text { polegadas } & \\
\end{array}$ & $43(13)$ & $66(20)$ & $82(25)$ & $82(25)$ & $115(35)$ & $115(35)$ & $20(6)$ & $33(10)$ & $46(14)$ \\
\hline $\begin{array}{ll}\text { Antena } & \text { tipo } \\
\text { Cone de } 8 & \\
\end{array}$ & $66(20)$ & $82(25)$ & $115(35)$ & $82(25)$ & $115(35)$ & $115(35)$ & $26(8)$ & $39(12)$ & $52(16)$ \\
\hline
\end{tabular}

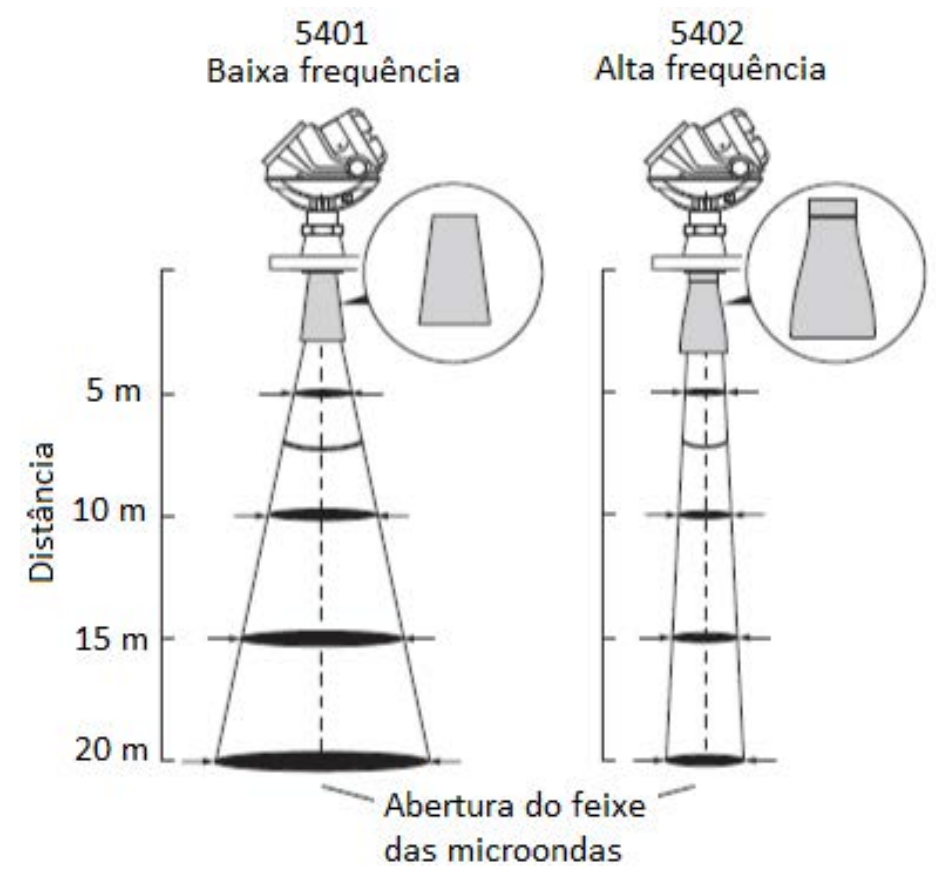

Figura 10 - Diferença de abertura do feixe de micro-ondas. Fonte: Baseado em Rosemount (2014).

\subsubsection{Configuração do radar e ajustes avançados}

Além do dimensionamento e instalação corretos do radar, a sua configuração é importante para que se tenha uma medição de nível otimizada. Para tanto é necessário que se conheça as condições de processo na qual a medição de nível será empregada.

As realimentações sobre o desempenho dos radares por parte dos usuários, levaram 
$\mathrm{R}(\Omega)$ Máxima resistência de carga

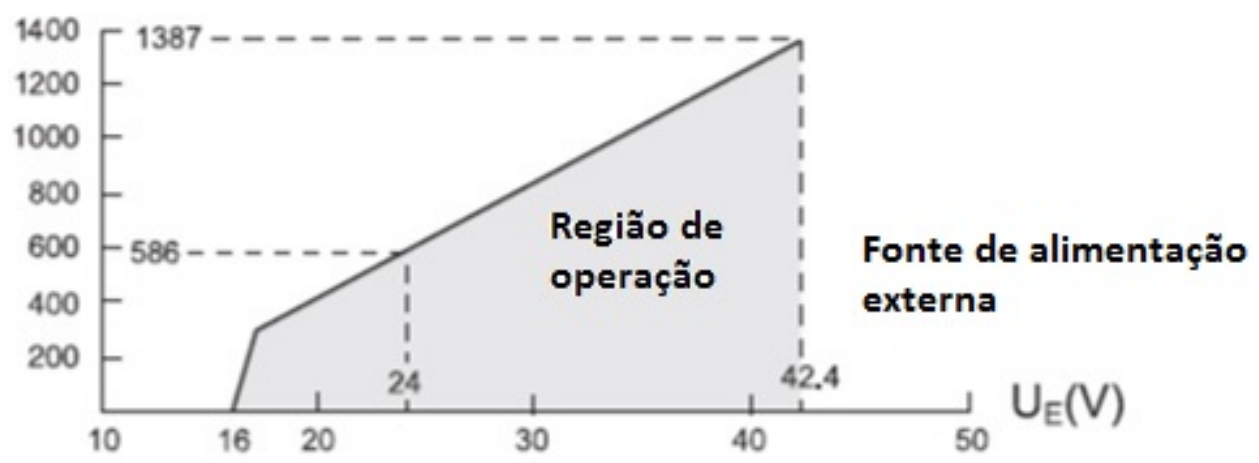

Figura 11 - Exemplo de curva de carga do radar. Fonte: Baseado em Rosemount (2014).

os desenvolvedores a criar quatro parâmetros na configuração dos radares relacionados às condições do processo para otimizar a medição de nível. Esses parâmetros são Espuma, superfície turbulenta, mudanças rápidas de nível e aplicação para sólidos.

Como padrão, o radar é capaz de acompanhar as mudanças de nível em até 1,5 pol. / s (40 mm / s). Quando o radar é configurado para isso, ou seja, a opção para rápidas variações de nível está selecionada, o radar pode acompanhar as mudanças de nível em até 8 in. / s (200 mm / s).

A superfície turbulenta pode ser originada por efeito dos esguichos no carregamento, misturadores, ou ainda, ebulição do produto. Normalmente, as ondas em um tanque são bastante pequenas e causam mudanças rápidas de nível localmente. Ao se configurar essa opção, o desempenho do transmissor irá melhorar quando existirem rápidas alterações no nível.

Outra opção que pode ser selecionada é a presença de espuma na superfície de medição. A definição deste parâmetro otimiza o indicador para condições com variações na amplitude dos ecos como ocorre quando há espuma. Quando a espuma é leve e arejada, o nível real do produto é medido. Para espuma densa, o transmissor mede o nível da superfície superior da espuma.

Como ilustrado na Figura 12, é possível escolher uma ou duas das opções entre as quatro possíveis:

Essas opções selecionadas, ajustam os parâmetros Echo timeout, close distance, search speed e FFT match threshold. Na Tabela 5 esses termos foram mantidos em inglês por serem os nomes dos registros empregados no software do radar.

Esses parâmetros foram levantados em testes de laboratório na fábrica e ajustados empiricamente escolhendo-se os valores que melhor se adequavam para as condições indicadas de processo. A Tabela 5 foi obtida escolhendo-se uma ou duas entre as quatro opções possíveis. Para a última linha da tabela foram escolhidas 3 opções, o que não é recomendado pelo manual. 
O parâmetro Echo timeout define o tempo em segundos, depois que o eco é perdido para o software do radar começar a procurar por um novo eco de superfície. O software não dispara a procura por um eco novo nem indica uma condição de alarme até que se finalize esse tempo.

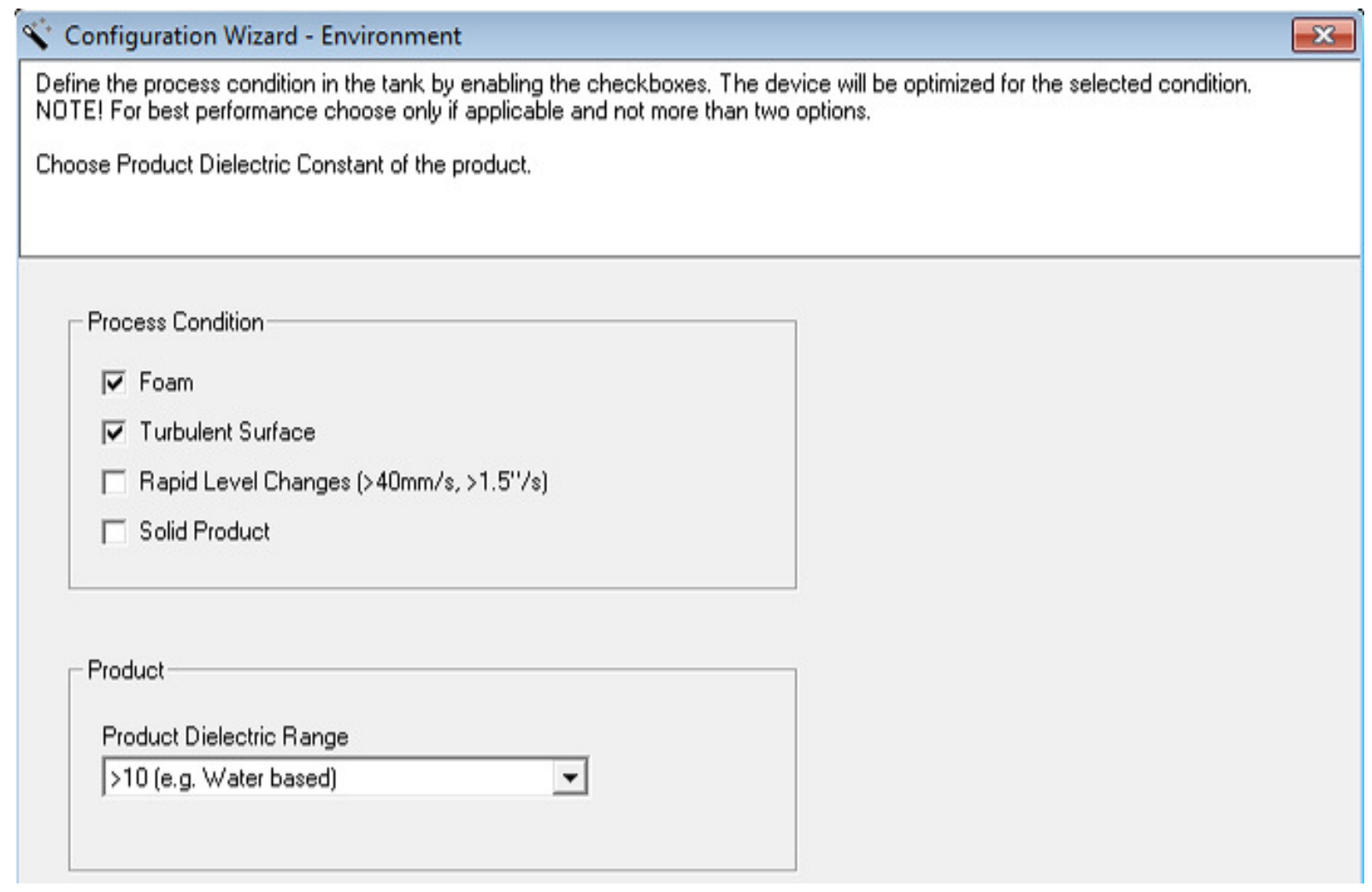

Figura 12 - Ajustes avançados.

O parâmetro close distance define uma janela centrada na posição da superfície atual, onde novos candidatos a ecos de superfície podem ser selecionados. O tamanho dessa janela será \pm o valor da close distance. Os ecos fora dessa janela não serão considerados e o software do radar escolherá o pico que tiver o sinal mais forte. Se há mudanças rápidas de nível no tanque, o valor do close distance pode ser aumentado para evitar que o transmissor perca o sinal do nível. Por outro lado, um valor elevado pode fazer com que o software selecione um eco inválido da superfície.

O registro search speed indica a velocidade de procura em que a janela é expandida quando o eco é perdido. Com isso, o radar começa a procurar a superfície no último valor de nível conhecido e aumenta gradualmente a região de pesquisa até que a superfície seja encontrada. Se esta variável não for definida, o radar procura em todo o tanque. Este parâmetro é normalmente usado para tanques com condições de processo turbulentas.

O registro FFT match threshold informa quanto o eco pode se mover entre duas medições consecutivas. 
Tabela 5 - Ajustes avançados.

\begin{tabular}{lcccc}
\hline \multicolumn{1}{c}{ Opções selecionadas } & $\begin{array}{c}\text { Echo } \\
\text { timeout } \\
(\mathrm{s})\end{array}$ & $\begin{array}{c}\text { Close } \\
\text { distance } \\
(\mathrm{mm})\end{array}$ & $\begin{array}{c}\text { Search } \\
\text { speed } \\
(\mathrm{m} / \mathrm{s})\end{array}$ & $\begin{array}{c}\text { FFT match } \\
\text { threshold } \\
(\mathrm{mm})\end{array}$ \\
\hline Nenhuma opção configurada & 60 & 400 & 0,05 & 240 \\
\hline Espuma & 180 & 400 & 0,02 & 240 \\
\hline Superfície turbulenta & 90 & 400 & 0,05 & 240 \\
\hline Variações rápidas do nível & 20 & 1000 & 0,50 & 600 \\
\hline Sólidos & 180 & 400 & 0,10 & 240 \\
\hline $\begin{array}{l}\text { Espuma + } \\
\text { Superfície turbulenta }\end{array}$ & 180 & 400 & 0,05 & 240 \\
\hline $\begin{array}{l}\text { Superfície turbulenta }+ \\
\text { variações rápidas do nível }\end{array}$ & 40 & 1000 & 0,10 & 600 \\
\hline $\begin{array}{l}\text { Variações rápidas do } \\
\text { nível + sólidos }\end{array}$ & 40 & 1000 & 0,50 & 600 \\
\hline $\begin{array}{l}\text { Espuma + variações } \\
\text { rápidas do nível }\end{array}$ & 40 & 400 & 0,10 & 240 \\
\hline Espuma + sólidos & 180 & 400 & 0,10 & 240 \\
\hline $\begin{array}{l}\text { Superfície turbulenta }+ \\
\text { sólidos }\end{array}$ & 180 & 400 & 0,10 & 240 \\
\hline $\begin{array}{l}\text { Espuma }+ \\
\text { superfície turbulenta }+ \\
\text { variações rápidas do nível }\end{array}$ & 60 & 400 & 0,10 & 240 \\
\hline
\end{tabular}

A Tabela 5 foi construída para se ter uma noção desses valores de registros citados acima dependendo das escolhas configuradas de espuma, superfície turbulenta, mudança rápida do nível e utilização com sólidos. A escolha de combinações dessas opções também estão ilustradas, embora, na prática, a seleção de espuma com sólidos não faça sentido na maioria das aplicações. É possível entender que, embora a escolha desses parâmetros sejam por tentativa e erro, existe uma lógica indicando que para o Echo timeout é maior quando se trabalha com espuma ou sólidos pois nessas aplicações é comum uma grande redução da amplitude do eco e um tempo maior para a captura dos ecos, proporciona uma medição mais confiável. O parâmetro close distance é maior para variações rápidas do nível porque é interessante manter uma janela maior de procura devido à rápida alteração do nível que ocorre com maior frequência para tanques de pequenos diâmetros. O registro search speed é maior para variações rápidas de nível e menor para espuma, porque geralmente quando se tem espuma, ela torna mais lenta a variação da superfície por sua própria viscosidade mais elevada do que a dos líquidos em geral.

Os testes para o primeiro cenário utilizam os filtros avançados de espuma e turbulência.

Além dos ajustes avançados, a configuração do radar permite o ajuste da curva de limiar (threshold); O software tem um algoritmo interno que permite um primeiro ajuste automático da curva de limiares conhecido como ATC - automatic threshold curve, baseado 
nos valores das amplitudes do que o software julga, de acordo com a sua configuração, ser o valor correto do nível em relação aos falsos ecos. Os pontos abaixo da curva do limiar são ignorados quando da escolha do próximo valor do nível como ilustrado na Figura 13. Esses pontos devem ser reajustados quando alterações no fluido do processo, ou condição de limpeza da antena forem alterados.

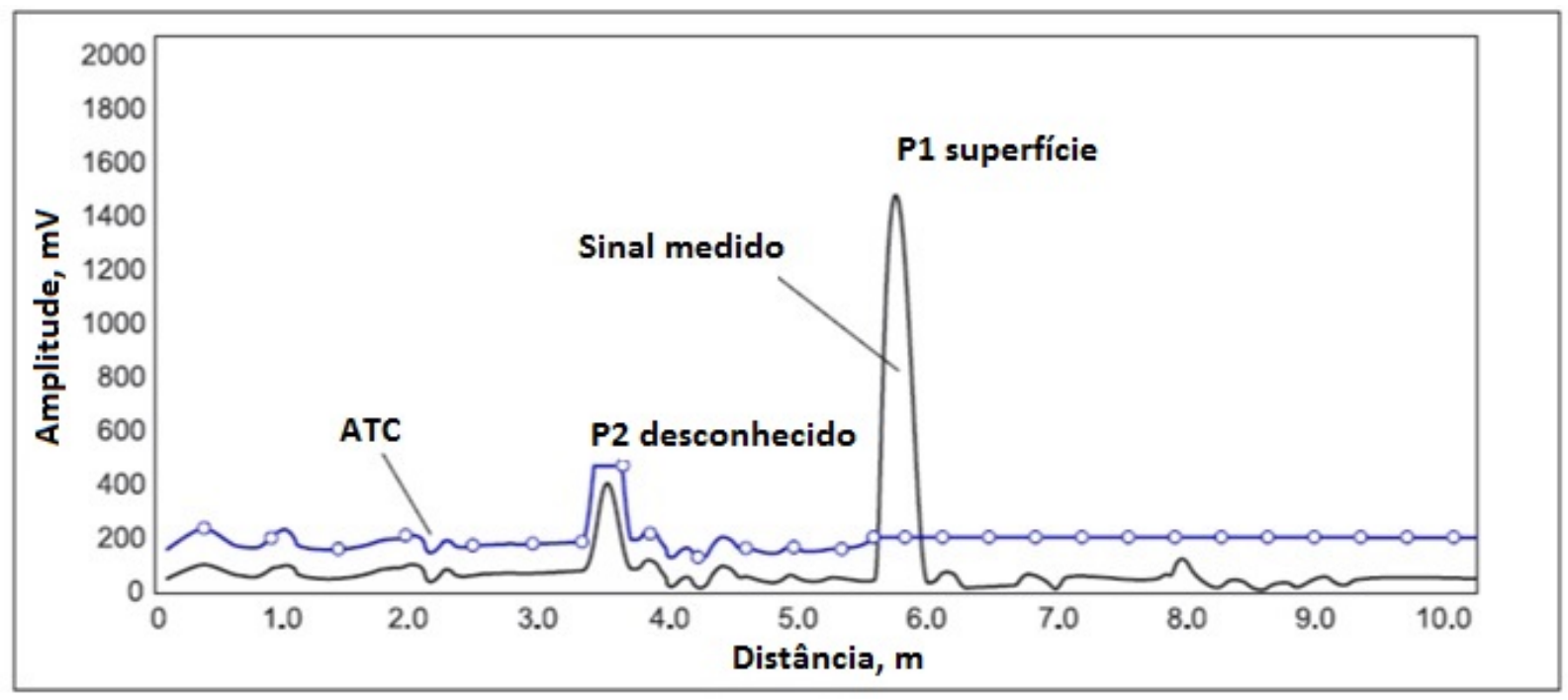

Figura 13 - Ajustes de limiares de amplitude da curva do eco. Fonte: Baseado em Rosemount (2014).

\subsection{Adequação da indicação e reporte de diagnósticos de nível conforme NAMUR NE107}

Essa seção de texto trata da padronização de diagnósticos desenvolvida pela norma NAMUR NE107. Basicamente, ela relata forma de categorizar os diagnósticos e alertas provenientes da instrumentação de campo para diferentes grupos dentro da planta industrial. Essas são adotadas por vários grupos ao informar os alarmes em softwares de gerenciamento de ativos como o AMS da empresa Emerson. Os diagnósticos detectados pela RNA ou SVM podem utilizar essa diretriz, reportando as classificações de forma mais rápida e resumida aos operadores e entregando mais detalhes do problema e de como resolvê-lo para o grupo de manutenção. NAMUR é uma associação internacional de usuários de indústrias de automação de processos e os objetivos principais da seção NE107 é a padronização da informação dos diagnósticos dos instrumentos de campo para melhorar a eficiência da operação da planta, aumentar a produtividade, reduzir custos e tornar a manutenção mais eficiente Endress\&Hauser (2011).

O operador precisa imediatamente ser informado sobre um mal funcionamento de um dispositivo crítico na planta para que ele possa tomar as medidas adequadas Berge (2014). Isso pode incluir a adoção de medidas de segurança, como colocar a malha em manual 
ou parar a unidade. O operador pode então decidir continuar com segurança até que a manutenção substitua o dispositivo, ou até mesmo esperar a próxima parada geral de manutenção na planta. Outros problemas de instrumentos que não requerem ação do operador, não são informados ao operador, somente ao pessoal da manutenção. Em situações críticas, os operadores precisam de informações para tomar decisões. As primeiras informações associadas com transmissores e válvulas são as variáveis de processo e variáveis manipuladas. O grupo de trabalho NAMUR 3, em conjunto com outros grupos, identificaram que para ajudar os operadores, o estado dos instrumentos também é uma informação importante. As indicações consistentes do estado do dispositivo para os operadores são definidas nas recomendações da norma NAMUR NE107. Os diagnósticos detalhados do dispositivo são utilizados pelo grupo de manutenção na planta para solução de problemas e planejamento de manutenção diária e de paradas gerais. A linguagem eletrônica de descrição do dispositivo (Electronic Device Description Language - EDDL) desempenha um papel importante na configuração e categorização dos diagnósticos dos instrumentos permitindo a filtragem e roteamento baseado nos estados de sinais da norma NAMUR NE107, bem como na exibição desses estados nos faceplates dos dispositivos.

Qualquer planta pode ter uma mistura de dispositivos de vários fornecedores e de diferentes tipos. Os tipos de autodiagnósticos de cada dispositivo são diferentes. Ou seja, cada tipo de dispositivo e fornecedor é único em relação a qual problema de dispositivo terá a sua saída analógica sinalizada como uma falha ou não. Além disso, o sistema de controle, o historiador da planta, parte do Intelligent Device Management software (IDM) do Sistema de Gestão de Ativos, e outros sistemas exibem a falha do dispositivo com ícones, cores e mensagens diferentes. Inconsistências como estas tornam difícil a interpretação do estado do dispositivo; não é fácil de determinar o que cada alarme de diagnóstico do instrumento significa, e quão grave e urgente ele é.

A recomendação NE107 define como os diagnósticos de dispositivos inteligentes com comunicação digital estão resumidos antes de ser comunicada, de preferência em tempo real, a partir do dispositivo para o sistema para permitir aos operadores tomar medidas apropriadas.

Os diagnósticos também são úteis como informação para a manutenção diária e planejamento de paradas (turnarounds). Por exemplo, os dispositivos podem ser capazes de prever a vida restante dos componentes que se desgastam, tal como uma vedação da haste, ou uma incrustação pode ser detectada previamente, antes de gerar um problema na operação da planta. É importante que o operador da planta não seja inundado com códigos de erros enigmáticos e detalhes de resolução de problemas de dispositivos. Isso poderia distraí-lo e fazê-lo perder o foco, não tomando as medidas mais adequadas. De qualquer forma, a solução de problemas dos dispositivos não é realizada pelo operador. Ela será realizada pelo técnico de manutenção. Portanto, a recomendação NE107 define quatro sinais de estados simples em que os diagnósticos de detalhes específicos do disposi- 
Tabela 6 - Categorização de problemas em instrumentos de campo. Fonte: Baseado em Berge (2014).

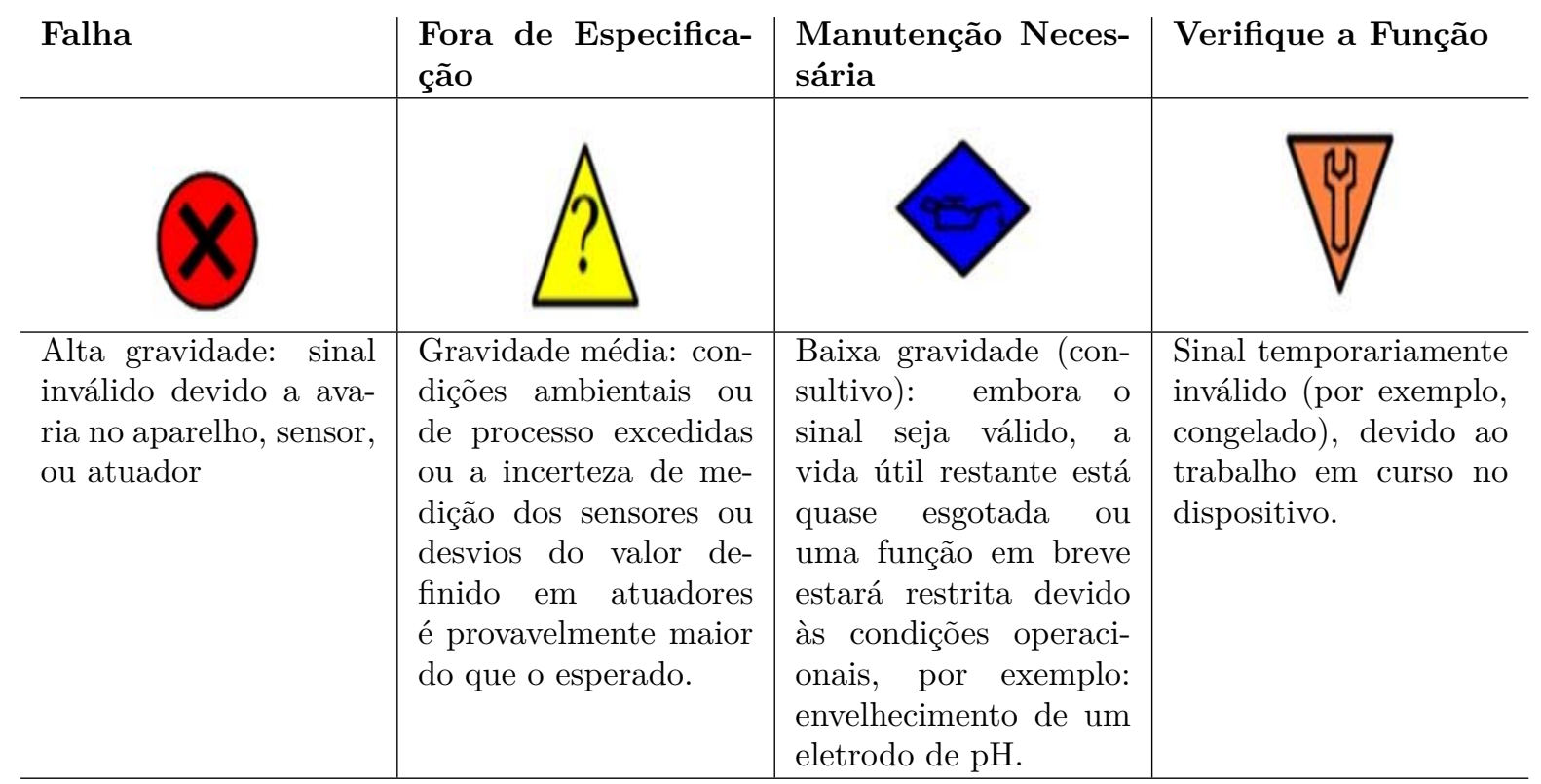

tivo são categorizados antes de serem comunicados ao sistema. É importante que apenas os sinais de estado NE107 simples sejam apresentados nos gráficos da operação. Essa categorização está indicada na Tabela 6 .

Os instrumentos comunicam alarmes de diagnóstico quando o auto-diagnóstico interno detectar problemas. Por exemplo, isso inclui a monitorização contínua de variáveis internas num posicionador de válvula pelo próprio dispositivo. Além disso, para monitorar as variáveis internas em transmissores e válvulas críticas para o processo pode-se se realizar o diagnóstico a partir do sistema se não forem suportados no próprio dispositivo. Problemas detectados podem ainda não identificar uma falha total, mas fornecer um aviso antecipadamente. O instrumento pode detectar a degradação, como resultado do desgaste ao longo do tempo em operação normal, o que tem um impacto sobre o desempenho e, portanto, para o processo. Os resultados de diagnósticos específicos do instrumento são resumidos em quatro sinais de estados NE107 no próprio dispositivo. Cada diagnóstico pode ser mapeado em uma das quatro categorias.

Os quatro códigos "Alta", "Média", "Baixa", "Não importante" indicados na Tabela 7 para automonitorização e diagnósticos em instrumentação de campo são baseados na prioridade do ponto de vista do usuário.

Fechando essa seção, é importante informar que os primeiros diagnósticos dos instrumentos de campo, em geral, visavam apenas o instrumento em si, indicando falhas em sua CPU, ou memória ou algum hardware, como um sensor interligado diretamente ao transmissor. Existe uma tendência de ampliação desses diagnósticos onde podem ser reportados não apenas esses diagnósticos mais básicos, mas também os relacionados ao processo nas vizinhanças do instrumento. Como exemplo, em Borg et al. (2009) foi de- 
Tabela 7 - Exemplos de diagnósticos para radares. Fonte: Baseado em NAMUR (2006).

\begin{tabular}{|c|c|}
\hline \multicolumn{2}{|r|}{ Radares de onda livre. } \\
\hline Prioridade & Falha \\
\hline Alta & $\begin{array}{l}\text { Atenuação devido a depósitos, incrustações ou condensado no interior ou sobre a } \\
\text { antena; }\end{array}$ \\
\hline Alta & Ecos falsos devido a depósitos locais ou incrustação; \\
\hline Alta & Algum produto ou umidade na área de acoplação da micro-ondas; \\
\hline Alta & $\begin{array}{l}\text { Uma forte atenuação do sinal (devido à mudança de produto, gás de absorção, } \\
\text { espuma, superfície com ondulações, distância muito grande, final de medição ou } \\
\text { baixa reflexão); }\end{array}$ \\
\hline Alta & $\begin{array}{l}\text { Mudança de velocidade do sinal de radar: pode ser devido a alta pressão na fase } \\
\text { gasosa; Uma falsa interpretação do sinal de superfície devido à ecos interferentes } \\
\text { (mutáveis ao longo do tempo ou de alta amplitude) a partir de estruturas internas } \\
\text { dos tanques como agitadores, tubulações para trocadores de calor, fundo do tanque } \\
\text { ou depósitos de material na parede do tanque; }\end{array}$ \\
\hline Alta & Bocal de instalação muito longo para a antena; \\
\hline Alta & Radar montado muito próximo à parede do tanque, bocais não verticais; \\
\hline Média & Corrosão em antena, desprendimento de revestimentos; \\
\hline Média & Forte atenuação do sinal devido à vapores ou poeira; \\
\hline Média & $\begin{array}{l}\text { Sinal de antena bloqueado (má instalação), por exemplo, diretamente acima bocal } \\
\text { de entrada do produto; }\end{array}$ \\
\hline Baixa & Eco muito forte (supermodulação); \\
\hline \multicolumn{2}{|r|}{ Radares de onda guiada: Medição de nível. } \\
\hline Prioridade & Falha \\
\hline Alta & $\begin{array}{l}\text { Ecos falsos devido à incrustação local ou "pontes", especialmente em antenas } \\
\text { coaxiais ou guia de onda duplos, ou curto-circuito em guia de onda duplos; }\end{array}$ \\
\hline Alta & Indicação errada ou sem indicação devido à espuma; \\
\hline Alta & Reflexão pobre (constante dielétrica, mudança do produto); \\
\hline Alta & $\begin{array}{l}\text { Localização muito perto da parede do tanque, internos, serpentinas de refrigera- } \\
\text { ção, depósitos na parede, antena entrando em contato com a parede do tanque } \\
\text { devido ao movimento da antena; }\end{array}$ \\
\hline Alta & Bocal de instalação muito longo com antenas simples ou com guia de onda duplo; \\
\hline Alta & $\begin{array}{l}\text { Ausência de uma superfície metálica para a reflexão do sinal de acoplamento } \\
\text { (antenas simples apenas); }\end{array}$ \\
\hline Média & Sobrecarga mecânica da sonda (tração); \\
\hline Média & Algum produto ou umidade no acoplador das micro-ondas; \\
\hline Média & Mudança de velocidade das micro-ondas devido à alta pressão na fase gasosa; \\
\hline \multicolumn{2}{|r|}{ Radares de onda guiada: Medição de interface. } \\
\hline Prioridade & Falha \\
\hline Alta & Sem interface clara, por exemplo, emulsão, separação incompleta; \\
\hline Alta & $\begin{array}{l}\text { Indicação errada devido a parametrização errada da constante dielétrica do pri- } \\
\text { meiro produto (camada superior); }\end{array}$ \\
\hline Alta & $\begin{array}{l}\text { Diferença muito pequena entre as constantes dielétricas das respectivas fases } \\
\text { (troca de fases); }\end{array}$ \\
\hline Alta & Existência de mais de uma interface; \\
\hline Alta & Primeira fase com espessura muito pequena ou constante dielétrica muito alta. \\
\hline
\end{tabular}


senvolvido um estudo onde se monitora o diagnóstico de linha de impulso ${ }^{1}$ obstruída em medições de vazão por princípio de pressão diferencial.

\subsection{Revisão bibliográfica}

Durante o processo de pesquisa nas bases científicas como a Scopus, IEEE e Periódicos CAPES, as combinações de palavras chave como level measurement, diagnosis, pressure transmitter, Neural Network, Industrial measurement, soft sensor, ultrasonic e svm foram utilizadas. Não foram encontrados todavia, trabalhos que diretamente referenciassem diagnósticos em radares utilizando redes neurais ou svm, o que torna esse trabalho inédito.

O artigo Carullo et al. (1996) trata de uma discussão de melhoria de desempenho que uma rede neural permite realizar para um medidor de distância ultrassônico baseado no tempo de deslocamento (TOF - time of flight) de um pulso ultrassônico. Para se atingir uma exatidão maior na medição da distância há uma correção de temperatura que não é necessária quando se trata de medidores por micro-ondas. Outra diferença é a faixa de medição do ultrassônico que atinge até aproximadamente $12 \mathrm{~m}$ e o medidor por micro-ondas pode trabalhar com faixas de $30 \mathrm{~m}$.

Em Dalci, Gulez e Mumcu (2004) o volume de um tanque de combustível de um automóvel é modelado de acordo com as dimensões que são armazenadas durante a fase de treinamento da rede neural. Qualquer alteração na estrutura do tanque é reconhecida e reportada ao usuário. Algumas diferenças que podem ser ressaltadas dessa referência para a tese atual são o tipo do sensor ultrassônico em vez do de micro-ondas, o ambiente do medidor que trata de um tanque de combustível e na tese o foco são tanques industriais e a finalidade de reconhecimento de alterações na estrutura do tanque enquanto na tese foram classificados problemas de medição.

Em Terzic, Nagarajah e Alamgir (2011) um estudo foi realizado para determinação da quantidade de fluido em tanques de dispositivos móveis como automóveis, aviões que apresentam uma condição de movimento do fluido. Para tanto um medidor capacitivo e uma técnica baseada em RNA faz a predição da quantidade atual do volume do fluido mesmo nas condições do tanque em movimento. Esse artigo é similar ao anteriormente descrito e à tese pela utilização de RNA e por utilizar um medidor de nível embora seja de outro princípio de funcionamento.

O artigo Kim e Lee (2011) trata do radar com tecnologia FMCW Frequency Modulated Continuous wave, informando que esse medidor tem recebido recentemente muita atenção como um sensor de medição de nível para reservatórios de óleo. Devido à característica de ter um sensor de micro-ondas sem contato, o radar não é afetado pelas mudanças na temperatura do processo, na pressão, ou pelo gás dentro do reservatório. Além disso, a

\footnotetext{
${ }^{1}$ tubulações de diâmetros pequenos, geralmente de $1 / 4$ ou $1 / 2$ polegadas e quase sempre feitas em aço inox que interligam as tomadas de processo ao instrumento de campo.
} 
precisão da medição não é afetada pela variação da densidade, condutividade ou constante dielétrica do objeto medido ou pela movimentação de ar acima da superfície do óleo. Estes benefícios desempenham um papel essencial na indústria de medição, devido à necessidade de um radar com alto desempenho. Na tese, o radar utilizado foi de tecnologia pulsada, que é diferente do FMCW embora apresente características similares como não ser afetados pelas alterações nas condições de processo como as de pressão, temperatura, viscosidade, densidade. O princípio de funcionamento do FMCW é diferente do pulsado porque as micro-ondas são enviadas continuamente com uma variação periódica da frequência, normalmente obedecendo o padrão de variação de uma onda dente-de-serra Rosemount (2013). A distância medida é avaliada através da diferença de frequência enviada e a recebida. O objetivo de análise de desempenho da medição também é diferente do foco da tese que é relativa à classificação dos padrões de problemas de medição do nível.

No artigo Faldella e Tucci (2009) é relatado que, independentemente das finalidades específicas e características intrínsecas, os dispositivos normalmente utilizados são abstratamente modelados em termos dos serviços que fornecem e dos sinais de saída ou realimentação que eles entregam ao sistema. Neste sentido, tais modelos proveem indicações precisas sobre os dispositivos que não se comportam como esperado, prontamente relatando a(s) causa(s) de cada falha e sugerindo possíveis soluções para a recuperação da falha. A validade da abordagem foi experimentalmente determinada pela realização de testes em máquinas automatizadas com uma ferramenta de diagnóstico múltipla desenvolvida com suporte a fieldbus. A ferramenta foi utilizada para a configuração preliminar de uma IMA (Industria Macchine Automatiche, Bologna, Italy) C24 empacotadora de saches de chá, caracterizada por uma taxa de produção de 350 sacos por minuto e um sofisticado equipamento de sensoreamento / atuação envolvendo cerca de setecentas linhas de entradas e saídas digitais. A verificação elétrica manual feita anteriormente demorava normalmente cerca de 8 dias, com uma média de 5 horas de trabalho por dia. Aplicando essa abordagem de modelagem, foi possível automatizar o diagnóstico de cerca de $70 \%$ das linhas de E/S com uma economia total de 4 dias. Em particular, o modelo tem demonstrado os seus melhores méritos na detecção de cruzamento de fios e fios faltantes. A abordagem manual exigiria, em tal ocorrência, a inspeção manual de todas as entradas para se detectar conexões faltantes. Usando a ferramenta as conexões defeituosas são imediatamente detectadas e enviados ao operador.

O artigo Zhang e Lin (2011) apresenta um sistema de controle distribuído baseado em fieldbus CAN, que monitora remotamente um sistema inteligente e gera diagnósticos de falhas na linha de produção de um triturador que utiliza o PLC MITSUBISHI e o protocolo CAN. O mostrador sensível ao toque do MITSUBISHI GT1575-VNBA foi escolhido para monitorar a linha de produção. Vários sinais medidos são transmitidos ao PLC através do CAN e módulos de entrada e saída distribuídos. A linha é de produção contínua. Seus 
dispositivos estão espalhados, e o ambiente de trabalho é ruidoso. A rede CAN é utilizada para monitorar remotamente a linha de produção. A aplicação mostra que o sistema de controle distribuído é simples, confiável e em tempo real.

O sistema inteligente de diagnóstico de falhas monitora a implementação de todos os equipamentos, incluindo as unidades eletrônicas que determinam o estado do barramento, unidades existentes e sensores para monitorar o estado operacional do equipamento de modo que uma falha do sistema é diagnosticada e rapidamente reparada. O sistema permite reduzir a necessidade de intervenção humana e aumentar a segurança e produtividade.

O computador host na sala de controle central monitora todas as variáveis como temperatura, pressão, velocidade, vazão, frequência e comutação de estado como início e parada do controle de vários tipos de atuadores elétricos de acordo com o processo de vazão. De forma similar ao artigo anterior, esse foca em diagnósticos mais gerais do sistema enquanto a tese é dirigida para problemas na medição do nível.

No artigo Prakash, Patwardhan e Shah (2010) um método para diagnósticos em um sistema não linear composto de três tanques foi apresentado.

Em Upadhyaya, Mathai e Eryurek (1990) é proposto que as redes neurais podem ser usadas para monitorizar o padrão de sinais em diferentes condições de funcionamento de uma planta geradora de energia. Para esta aplicação, os padrões de entrada e saída são os mesmos. A rede é treinada utilizando " $n$ " números de sinais, cada padrão correspondendo a um determinado instante de tempo. Uma vez que a rede seja determinada, ela pode ser usada para estimar o padrão do sinal de teste. Os desvios entre as variáveis de entrada e saída indicam uma possível falha na instrumentação ou um novo estado de operação. Esta técnica foi aplicada à dez sinais retirados do Experimental Breeder Reactor-I1 (EBR-11), que foram adquiridas durante a partida da planta. O desvio padrão do erro de predição da rede e também o erro percentual são mostrados individualmente para os dez sinais. Este estudo indica a eficácia de uma rede neural para a predição de variáveis em toda a planta. Os valores normalizados dos sinais podem ser exibido para o operador, juntamente com a tolerância permitida entre os valores previstos e medidos.

Em Reyes, Vellasco e Tanscheit (2012) é informado que as manutenções preventivas de sensores asseguram o seu funcionamento correto durante um certo período de tempo, mas não garantem que eles permaneçam sem defeito por outros períodos. Em plantas industriais, a análise dos sinais fornecidos pelos sensores que monitoram os processos de produção é uma tarefa difícil em virtude da grande dimensão dos dados. Portanto, uma estratégia de monitoramento e correção on-line para múltiplos sensores é necessária. Este trabalho propõe a utilização de Redes Neurais Auto-Associativas com Treinamento Robusto Modificado e do Teste Sequencial da Razão de Probabilidade (SPRT) em um sistema de monitoramento para auto-correção on-line e detecção de anomalias nas medidas geradas por um grande número de sensores. Diferentemente de modelos existentes, o 
sistema proposto visa a utilização somente de uma RNA para reconstruir os sinais dos sensores com falha. O modelo é aliado com uma base de dados que contém as medidas de sensores industriais que controlam e realizam o monitoramento de um motor de combustão interna, instalado em um caminhão de mineração. Os resultados obtidos mostram a capacidade do modelo proposto de mapear e corrigir, com um baixo nível de erro, os sinais dos sensores que apresentam falhas.

Em Gonzaga et al. (2009) são apresentados o desenvolvimento e a implementação industrial de um sensor virtual (soft-sensor) no processo de produção do PET (polyethylene terephthalate). Este sensor, baseado em uma rede neural artificial (RNA) feed-forward, foi usado para fornecer estimativas on-line da viscosidade do PET, necessárias para o controle do processo. O sensor também foi utilizado para o fornecimento de medições redundantes da viscosidade que podem ser comparadas com os resultados obtidos a partir do viscosímetro instalado no processo. Foi demonstrado que a RNA foi capaz de adequadamente inferir a viscosidade do polímero, de um modo que o sensor pode ser utilizado em um controle de processo em tempo real.

Embora os viscosímetros relacionados a este trabalho normalmente fornecem uma medição de viscosidade confiável, um cuidado especial deve ser tomado para se assegurar a perfeita operação dos sensores, como adequada temperatura e regulação da velocidade da bomba durante a operação do processo. Apesar de todos os esforços para evitar problemas operacionais, a obstrução dos capilares e a subsequente falha na bomba ocorrem frequentemente. Nesses casos, os viscosímetros terão valores incorretos da viscosidade do PET e esse problema é somente detectável através de análise laboratorial, causando um atraso de tempo considerável. Esse atraso resulta em problemas como a produção de um polímero fora da especificação e intervenções nos viscosímetros para realizar limpeza nos capilares, troca da bomba, calibração do transmissor de pressão, etc. Para eliminar as dificuldades técnicas associadas com a medição em tempo real da viscosidade do PET, os autores propuseram o desenvolvimento de um sensor baseado em redes neurais artificiais (RNA) para prover estimações confiáveis desta propriedade. A estimação da viscosidade foi utilizada na estratégia de controle no processo industrial de polimerização. Desde que o sensor baseado em software demonstrou ser capaz de inferir valores corretos de viscosidade, ele foi utilizado na malha de controle principal enquanto o viscosímetro foi mantido operando em paralelo, para que fosse mantida a segurança. Para garantia da qualidade das predições do sensor, um procedimento de segurança operacional da planta foi implementada para detecção de qualquer erro em ambos sensores, tanto no viscosímetro quanto no sensor baseado em RNA: quando o erro absoluto entre a viscosidade medida e a estimada for maior que 50 poise, uma amostra do polímero é analisada em laboratório para verificar qual valor está mais preciso. Esse procedimento de segurança será importante para identificar se a RNA precisará ser retreinada, através da atualização do banco de dados ou se o viscosímetro precisa passar por manutenção. Outro procedi- 
mento foi implementado para evitar possíveis erros que possam ocorrer quando o erro é baseado em apenas uma única amostra. Essa estratégia considera a média dos erros ao longo do tempo.

No artigo Souzat, Hossrit e Hossrit (2000), uma abordagem neural foi desenvolvida para calcular o grau de envelhecimento relativo entre vários tipos de transformadores pertencentes a um determinado grupo. O treinamento da rede neural é baseado na avaliação dos níveis de contaminação do óleo em relação à características de degradação do papel de isolamento obtida a partir de testes de laboratório. As RNAs também são utilizadas para classificar o envelhecimento de transformadores com base na análise de contaminantes do óleo a partir de testes laboratoriais.

Na referência Iliyas et al. (2013) é informado que a detecção inferencial, ou detecção através de software, ganhou popularidade nos últimos anos como uma alternativa aos sistemas de monitoramento contínuo de emissões devido à sua simplicidade, confiabilidade e relação custo-benefício, em comparação com sensores de hardware similares. Neste trabalho foi abordado o problema de emissão de NOx utilizando um modelo de fornalha de uma caldeira industrial e uma estrutura de rede neural de alta performance foi proposta para uma previsão de $\mathrm{NOx}$ assim como de $\mathrm{O}_{2}$. A caldeira estudada possui $160 \mathrm{MW}$, a gás natural, utilizando água para geração de vapor, com dois queimadores alinhados verticalmente. O modelo da caldeira é um problema 3D que envolve turbulência, combustão, radiação, além de modelagem de NOx. O modelo computacional 3D da dinâmica dos fluidos é desenvolvido utilizando o pacote de simulação Fluent. O modelo proporciona cálculos da distribuição de temperatura 3D, assim como a taxa de formação do poluente NOx, permitindo uma melhor compreensão de como e onde as moléculas de NOx são produzidas. A caldeira foi simulada sob várias condições de operação. Os dados gerados são então utilizados para o desenvolvimento inicial e avaliação de sensores baseados em software utilizando redes neurais para a predição de emissão com base na medição do desempenho do processo convencional. A performance do sensor proposto foi avaliada utilizando dados reais de uma caldeira industrial. O sensor desenvolvido obtém uma precisão comparável ao analisador contínuo de emissão, no entanto, com substancial redução dos custos de equipamento e de manutenção.

Outra aplicação de RNAs em diagnósticos para indicação de falhas pode ser encontrado em Najafi, Culp e Langari (2004) no qual a RNA é utilizada para localizar o sensor defeituoso e também estimar o valor real da sua saída. A entrada para a RNA é o dado medido no sistema real (ambas as variáveis de entrada e de saída) e a saída para a RNA é o dado reconstruído por ela. Se os dados de entrada são livres de falha, então a saída da RNA será igual a entrada e a diferença entre a saída e a entrada será zero. Quando uma das entradas está contaminada, a saída correspondente não irá seguir a entrada e a diferença entre elas será diferente de zero. Uma situação similar ocorre quando as leituras dos sensores são contaminadas por ruído. Nessa situação, as leituras do sensor são 
afetadas por ruídos comuns em muitas aplicações industriais. A RNA é capaz de corrigir a leitura deste sensor, apesar da presença do ruído.

Um artigo semelhante ao citado anteriormente é o Paviglianiti e Pierri (2006) onde um esquema para a detecção e isolamento das falhas de sensores em reatores químicos é proposto. O esquema é baseado em um banco de dois observadores para geração residual que garante a detecção da falha do sensor e isolamento na presença de distúrbios externos e incertezas do modelo. As estimativas fornecidas pelos observadores e as medidas adquiridas pelo sensor são processados por um sistema de tomada de decisão (DMS) que fornece informações sobre o sensor defeituoso e um valor medido confiável. A fim de testar a eficácia da abordagem proposta, um estudo de caso baseado nas simulações foi desenvolvido.

Em uma fábrica de produtos químicos, um sensor defeituoso pode causar degradação no desempenho do processo como a redução da qualidade do produto ou acidentes fatais por exemplo, causado pela perda do controle da temperatura. Técnicas de detecção de falhas podem prevenir essas consequências indesejadas. A maioria das abordagens de diagnósticos de falhas (FD) foram propostas para processos com curso estável (por exemplo, reatores CSTR), mas a aplicação dessas técnicas em processos de fornos químicos são normalmente difíceis, pois a dinâmica deles não é linear e as condições de operação intrinsecamente instáveis.

O ponto fundamental para a detecção e isolamento de falhas é o desenvolvimento de um sistema adequado de tomadas de decisão (DMS) que, baseado nas medições disponíveis (sensores físicos) e as estimações realizadas (sensores virtuais), decide se e onde a falha ocorreu, isola o possível sinal que possui falha e envia como saída, um sinal correto, substituindo o sinal que foi isolado. A lógica do Eleitor/Monitor (o sub-sistema da DMS que determina o sinal correto) implementado é baseado na suposição de que não ocorram falhas simultâneas nos sensores.

Em Manders e Barford (2000), um software para realizar diagnósticos foi desenvolvido para um sistema de três tanques acoplados. O sistema é equipado com um sistema de medição e controle distribuído baseado em transdutores inteligentes com computação embarcada e recursos de rede que usam o modelo determinado na IEEE 1451.1. O sistema de diagnósticos opera on-line em uma estação de trabalho, que aparece na rede como outro nó transdutor. A técnica de diagnósticos tem vários aspectos que permitem a distribuição da funcionalidade de diagnóstico e monitoramento em uma rede de processadores embarcados. Além disso, como sistemas distribuídos de controle e medição crescem em tamanho e complexidade, se tornará cada vez mais importante a detecção e isolamento de falhas tanto no sistema em observação, como no sistema de medição e controle, além de possibilitar a análise e diagnósticos do transdutor.

O artigo Suna e Berns (1996) elucida que as tubulações de óleo e gás devem ser examinadas em intervalos regulares para análise de defeitos como perda de metal. Para 
tanto, se utiliza um pig instrumentado, que é um elemento móvel contendo vários sensores e registradores. Este aparelho é colocado dentro da tubulação e ao percorrê-la, registra milhares de dados da espessura da parede ao longo do comprimento da tubulação. Esses dados são analisados posteriormente para análise de falhas. A rede neural é treinada com os dados provenientes do pig e informações de especialistas em alguns trechos para poder generalizar e analisar outros trechos da tubulação.

Outras aplicações industriais utilizando redes neurais estão presentes em Paviglianiti e Pierri (2006) e em Bloch et al. (1997). Na primeira, a detecção e isolamento da falha de sensores é feitas para reatores químicos. Para isso, uma rede RBF é usada para estimar a reação cinética do reator e indicar falhas. Na segunda referência (Bloch et al. (1997)) é relatado que a melhoria do desempenho de um processo de produção complexo, como a linha de galvanização por imersão a quente na Sollac de Florange (França) precisa integrar várias abordagens, incluindo o monitoramento da qualidade, diagnósticos, controle e métodos de otimização. Estas técnicas podem ser agrupadas sob o termo de controle inteligente e tem como objetivo melhorar o funcionamento do processo, bem como a qualidade dos produtos entregues. O controle do processo de revestimento, altamente não-linear, é dividido em duas partes. O ciclo térmico ideal da liga é determinado utilizando-se uma rede neural de função de base radial, a partir de um banco de dados construído a partir de medições registradas. O controle do forno de recozimento, que é considerado como o equipamento mais importante, é realizado através da mistura de um modelo inverso do forno estático baseado em uma rede perceptron feedforward com multicamadas e uma malha de controle. Critérios robustos de aprendizagem são utilizados para eliminar possíveis valores discrepantes na base de dados. No fim desse processo, a rede neural é configurada para a melhoria da capacidade de generalização. O processo é muito complexo para a modelagem direta com base em leis físicas, e por isso, é inicialmente controlado por operadores humanos. O operador da planta é capaz de lidar com não-linearidades na planta, e, lentamente, variar os parâmetros. Assim, uma das idéias básicas do estudo apresentado, o qual pode ser chamado de uma aplicação de controle inteligente, é incorporar os atributos criativos e flexíveis de controladores humanos, evitando ao mesmo tempo as suas características associadas de insegurança.

Em D’Emilia, Marra e Natale (2007) é informado que o controlador PID (proporcional, integrativo, derivativo) está entre as soluções mais difundidas nas aplicações de automação industrial, principalmente devido à sua estrutura simples e também por ser robusto para a maioria das situações comuns de controle de processos. Em vários processos industriais, muitas centenas deste tipo de controlador podem ser instalados e cada um deles deve ser submetido a um ajuste (tuning) específico, de modo a individualizar a dinâmica do processo para uma estratégia de controle adequada e eficaz. Na maior parte dos casos, a sintonia dos parâmetros característicos de um controlador PID é um procedimento fortemente dependente do conhecimento pessoal e da habilidade do operador 
da planta, embora existam guias teóricos para a realização desse ajuste. Portanto, um tempo considerável deve ser gasto para a sintonização dos PIDs. O desvio-padrão dos coeficientes do PID é influenciado por muitos aspectos, dependendo do modelo de aproximação, da incerteza dos instrumentos de medição, efeitos ambientais e da necessidade da utilização de técnicas de processamento de dados capazes de encurtar o tempo de duração do auto-ajuste. Melhorar esses aspectos sem afetar a precisão da sintonia, é muito útil para a prática em plantas industriais. Na verdade, a utilização de um método para o auto-ajuste do controlador PID com base em uma abordagem da rede neural permite reduzir o tempo necessário para o auto-ajuste com relação aos métodos tradicionais, sem afetar o desvio padrão estimado e, consequentemente, a adequação do auto-ajuste.

O artigo Simon e Hungerbuhler (2010) descreve a análise de dados com base no reconhecimento de padrões de um forno secador industrial e na comparação de três técnicas de inteligência artificial desenvolvidas para executar tarefas de classificação: redes neurais treinadas utilizando o método Levenberg-Marquardt com regularização Bayesiana, o modelo neuro-fuzzy e o modelo em fuzzy Takagi-Sugeno. Os classificadores são utilizados para quantificar o tempo do forno secador e sua variação durante um certo período de produção. O método de reconhecimento de padrão apresentado implementa uma abordagem de aprendizagem supervisionada e baseia-se nos perfis de medição de pressões registrados pelo software de gerenciamento de dados da planta: PI System da OSIsoft. Verifica-se que as redes neurais treinadas com a regularização Bayesiana mostraram o desempenho mais robusto na classificação em relação à seleção do limiar de separação. Além disso, conclui-se que a aplicação de técnicas de inteligência artificial em fábricas de produção química é viável e fornece informações úteis para fins de monitoramento de desempenho do processo. Os resultados de reconhecimento de padrões apresentados neste documento não são para um caso específico e podem ser utilizados para o acompanhamento de uma grande variedade de processos de secagem, desde que as características do perfil de pressão - verificação de vácuo, diminuição da pressão, quebra de vácuo - não dependam dos produtos químicos que estão em processo de secagem.

Enquanto as redes neurais e modelos neuro-fuzzy são técnicas para aplicativos de reconhecimento de padrões estabelecidos, os modelos fuzzy Takagi-Sugeno também foram utilizados com sucesso. Além disso, verificou-se que, ao selecionar corretamente o limiar de separação dos modelos, todos podem executar igualmente bem. Além disso, a suposição de que qualquer um destes modelos iria servir para o reconhecimento de padrões foi confirmada. Neste estudo as redes neurais treinadas com a regularização Bayesiana mostraram o mais robusto desempenho de classificação. O desempenho dessas redes neurais foi marginalmente influenciado pelo tamanho da rede e limiar de classificação dos dados. Além disso, estas redes exibem características semelhantes de interpolação, embora o número de neurônios possa ser significativamente diferente.

Sensores baseados em software desempenham um papel importante na previsão dos 
valores das variáveis de processo a partir do conhecimento de medições realizadas no processo Pani e Mohanta (2012). A estimativa do tamanho das partículas é essencial para um controle eficiente de um sistema de moagem. Devido ao alto consumo de energia nos processos de moagem de cimento e da indisponibilidade de sensores confiáveis para um monitoramento contínuo, sensores baseados em software possuem um amplo range de aplicação em moinhos de cimento. Cimenteiras modernas estão utilizando cada vez mais moinhos de rolos verticais para a moagem. Nesse artigo, um modelo de rede neural baseado em PCA (pincipal component analisys) do moinho de cimento foi desenvolvido baseado nos dados obtidos da planta para a realização da estimação da granulometria do cimento. As variáveis do processo de moagem foram coletadas de uma cimenteira com uma capacidade de moagem de $235 \mathrm{TPH}$ (toneladas por hora). Os dados adquiridos são pre-processados para a remoção de valores duplicados e inserção de valores faltantes. A análise dos principais componentes de entrada foi realizada para transformar as variáveis originais para um número menor de componentes principais não inter-relacionados. Os principais valores foram divididos em dois grupos, sendo um de treinamento e outro de validação. O conjunto de treinamento foi utilizado para o desenvolvimento de uma rede neural backpropagation que foi testada com o conjunto de validação. Os resultados da simulação demonstraram uma satisfatória capacidade de predição do modelo desenvolvido em relação aos modelos de regressão linear e regressão dos principais componentes.

Esses trabalhos citados Faldella e Tucci (2009), Zhang e Lin (2011), Prakash, Patwardhan e Shah (2010), Upadhyaya, Mathai e Eryurek (1990), (REYES; VELLASCO; TANSCHEIT, 2012), Gonzaga et al. (2009), Iliyas et al. (2013), Najafi, Culp e Langari (2004). Manders e Barford (2000), Suna e Berns (1996), Paviglianiti e Pierri (2006), Bloch et al. (1997), D’Emilia, Marra e Natale (2007), Simon e Hungerbuhler (2010), Pani e Mohanta (2012) informam sobre diagnósticos, classificações e estimações utilizando sistemas inteligentes aplicados a ambientes industriais. A tese também é focada nesses assuntos, porém ela é voltada para a classificação de problemas pontuais da medição de nível, sem envolver todo o sistema.

Em Mirabella e Raucea (2006) um software para fins educacionais emula um gerador de energia a partir de combustíveis fósseis. Vários tipos de sensores e atuadores podem ser escolhidos bem como vários tipos de redes de comunicação. É possível ainda se estimar o grau de degradação das válvulas e analisar como isso afeta o sistema. O software produz gráficos que permitem aos alunos monitorar e avaliar o comportamento e desempenho de sistemas de controle. Esses elementos gráficos são também indicados nas diretivas da norma NAMUR e, pretende-se que esse trabalho dessa tese possa ser utilizado dentro de um ambiente de software de gerenciamento de ativos como em Mitchem (2004), no qual é abordado o tema de gerenciamento dos transmissores inteligentes. Esses instrumentos são amplamente utilizados nas indústrias de processo para medir alguns aspectos de um processo automatizado de produção e transmitir essas informações para o computador. 
Eles estão em refinarias, indústrias químicas, papeleiras e centrais geradoras de energia para medir e relatar vazão de fluidos, temperaturas, pressões, bem como níveis de tanques e posições de válvulas em pontos específicos do processo. O computador de controle usa as entradas provenientes destes instrumentos, comumente chamados transmissores, para determinar quando deve-se realizar mudanças, sob a forma de sinais de saída, para se manter as tarefas da planta industrial em funcionamento. Os transmissores inteligentes atuais vão além de reportar uma única variável. Eles usam microprocessadores para salvar uma variedade de informações, incluindo configurações de calibração, condições operacionais e outros dados de diagnóstico. Esta informação adicional pode ser acessada diretamente a partir de um instrumento utilizando um dispositivo portátil ou a partir da rede do sistema de controle através do protocolo de comunicação HART utilizando software escrito especificamente para este propósito. Uma grande família de transmissores inteligentes e posicionadores de válvula digitais está atualmente em uso no mundo a partir de uma ampla gama de fabricantes. No entanto, antes de serem instalados e colocados em operação, estes transmissores devem ser verificados e calibrados para garantir o correto funcionamento. Isto pode ser uma tarefa demorada e dispendiosa para quem contrata serviços de elétrica e instrumentação. Nesse contexto, o software de gerenciamento de ativos permitiria reportar graficamente ao usuário as classificações dos problemas obtidos desenvolvidos na tese.

As referências apresentadas envolvem técnicas diferentes de sensoreamento e medição, classificações utilizando sistemas inteligente, diagnósticos de sensores e, por último, formas de se reportar os resultados através dos gráficos de softwares de gerenciamento de ativos. Outras referências estão presentes no próximo capítulo da tese com relação às RNAs e SVMs. Essas referências não foram inseridas nessa seção pelo entendimento de que são específicas dos classificadores e que estariam melhor localizadas num capítulo sobre esse tema.

\subsection{Procura por patentes}

As bases INPI (Brasil), USPTO (USA) e ESPACENET (Europa) foram consultadas para verificar se já existe alguma patente que trate de uma aplicação semelhante ao que está em desenvolvimento nessa tese.

Procurando por radar diagnosis na ESPACENET um total de 25 referências apareceram. Entre essas, 4 referências estão relacionadas a radares para processo, mas todas voltadas para os testes de circuitos internos, ou de acoplamento entre a placa eletrônica e a antena.

Na base USPTO, procurando por radar diagnosis, apareceu uma referência, porém relacionada a uso de radar para checar estrutura (rachaduras) de pontes ou outras construções civis. 
Procurando na base INPI, por diagnóstico de radar, nenhuma referência foi encontrada. Fazendo a busca somente por radar, 114 referências foram encontradas. As relacionadas à medição de nível são poucas e se referem à desenvolvimento de medidores de nível por radar de empresas como a MAGNETROL. Não foi encontrado nada semelhante ao que se propõe no desenvolvimento da tese. 


\section{Classificadores: SVM e RNA}

Dentre os classificadores encontrados em pesquisa bilbiográfica nas bases científicas como Bayes, ANFIS (Adaptive Neuro-Fuzzy Inference Systems), RNA e SVM, os dois últimos apareceram com uma frequência da ordem de mais de $90 \%$ em relação aos dois primeiros com as palavras-chave citadas no início da seção 2.9 da tese. Portanto, os classificadores com base em redes neurais e support vector machines foram utilizados. Essa seção contem informações sobre esses classificadores iniciando por um breve histórico das máquinas de aprendizagens.

O problema do aprendizado a partir dos dados tem sido investigado por filósofos ao longo da história sob o nome de inferência indutiva. Até o século 20 não era reconhecido que a indução pura era impossível a menos que se concebesse um conhecimento anterior, esse conhecimento essencial foi publicado por Popper (1959). Esse assunto foi muito estudade dentro da estatística. Gauss propôs a idéia da regressão dos mínimos quadrados no século 18 enquanto a abordagem de Fisher (1988), em 1930, para classificação, ainda provê a base para métodos e análises atuais. Em 1950, Turing (1950) propôs a idéia de máquinas de aprendizagem contestando a crença comum de que as máquinas podem fazer somente aquilo que os seres humanos sabem ordená-las a fazer. Alguns anos depois, sugiram exemplos de máquinas de aprendizagem como o de Samuel (1959) que aplicava o conceito de aprendizado por reforço. Na mesma época, Frank Rosenblatt desenvolvia o conceito do perceptron. O desenvolvimento de algoritmos de aprendizagem se tornaram um importante campo dentro da inteligência artificial, possibilitando o surgimento das máquinas de aprendizagem. O support vector machines foi introduzido por Vapnik e seus colegas no artigo COLT Boser, Guyon e Vapnik (1992), descrito mais detalhadamente em seu livro Vapnik (1998).

O primeiro algoritmo para aprendizado de classificação linear é o procedimento proposto por Frank Rosenblatt em 1956 denominado perceptron. Trata-se de um procedimento que se inicia com os vetores de pesos aleatórios e se atualizam em cada iteração de forma a reduzir o erro com relação às saídas desejadas. Esse prodedimento tem garantia de convergência desde que exista um hiperplano que corretamente classifique os dados de 
treinamento. Nesses casos é dito que os dados são linearmente separáveis.

Support vector machines são sistemas de aprendizagem que utilizam um espaço de hipótese de funções lineares num espaço de características com dimensão alta, treinado com um algoritmo de aprendizagem da teoria de otimização e da estatística. Essa estratégia de aprendizado foi introduzida por Vapnik e seus colegas onde o uso das funções de kernel é a chave da eficiência para a implementação do espaço de características.

A disponibilidade dos sistemas de aprendizado é de fundamental importância porque há várias tarefas que não podem ser resolvidas por técnicas clássicas de programação, por exemplo por não existir modelos matemáticos para essas aplicações.

Algumas que podem ser citadas são busca de genes na sequência de DNAs, implementação de filtros de emails e a detecção e reconhecimento de objetos em visão computacional. O aprendizado de máquinas pode prover soluções para cada um desses problemas.

Um problema de aprendizado com saídas binárias é classificado como um problema de aprendizado binário, um problema com um número finito de categorias é conhecido como classificação multiclasse. Para saídas reais, ele é conhecido como regressão.

A habilidade de classificar corretamente os dados que não fazem parte do grupo de treinamento é a generalização; e essa é a propriedade que deve ser otimizada.

O algoritmo perceptron pode gerar várias soluções diferentes dependendo da ordem que as entradas são processadas. Isso implica em que algumas dessas soluções podem não ser igualmente úteis. A Figura 14 ilustra a separação de grupos pelos hiperplanos h1, h2, h3 e h4.

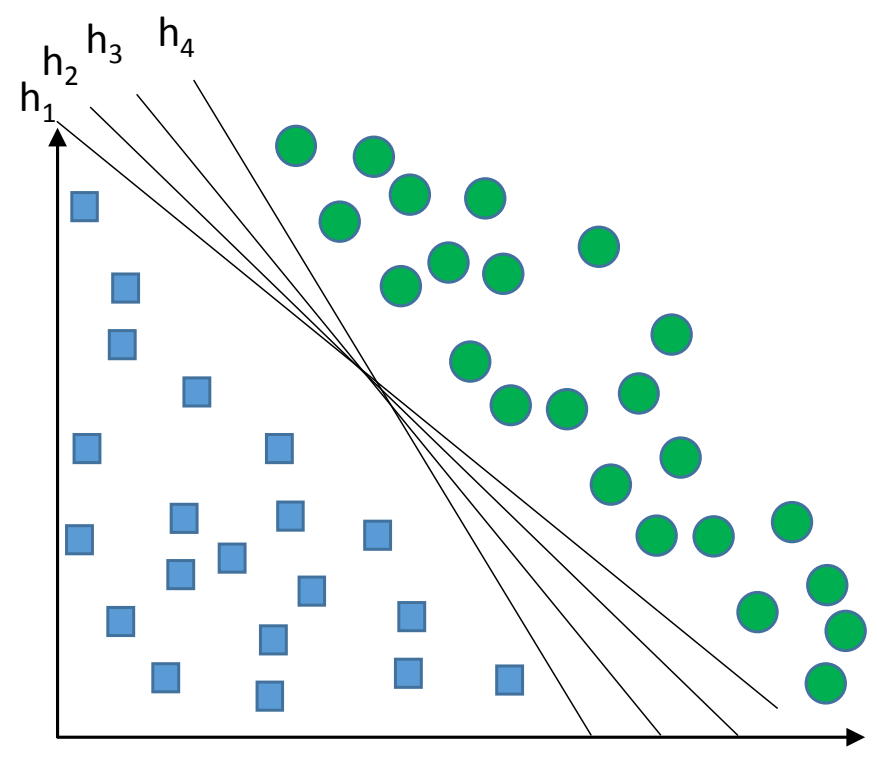

Figura 14 - Hiperplanos da RNA.

Uma forma de se aperfeiçoar esse algoritmo é tentar otimizar uma função de custo diferente que assegure que a solução exista e seja única. Por exemplo, pode-se escolher 
um hiperplano que tenha máxima distância dos pontos de separação entre os grupos classificados. Essa solução garante a convergência com a máxima margem de distância entre os pontos, também conhecida como máxima estabilidade. A Figura 15 ilustra a separação de grupos pelo hiperplano otimizado do SVM em relação aos da RNA.

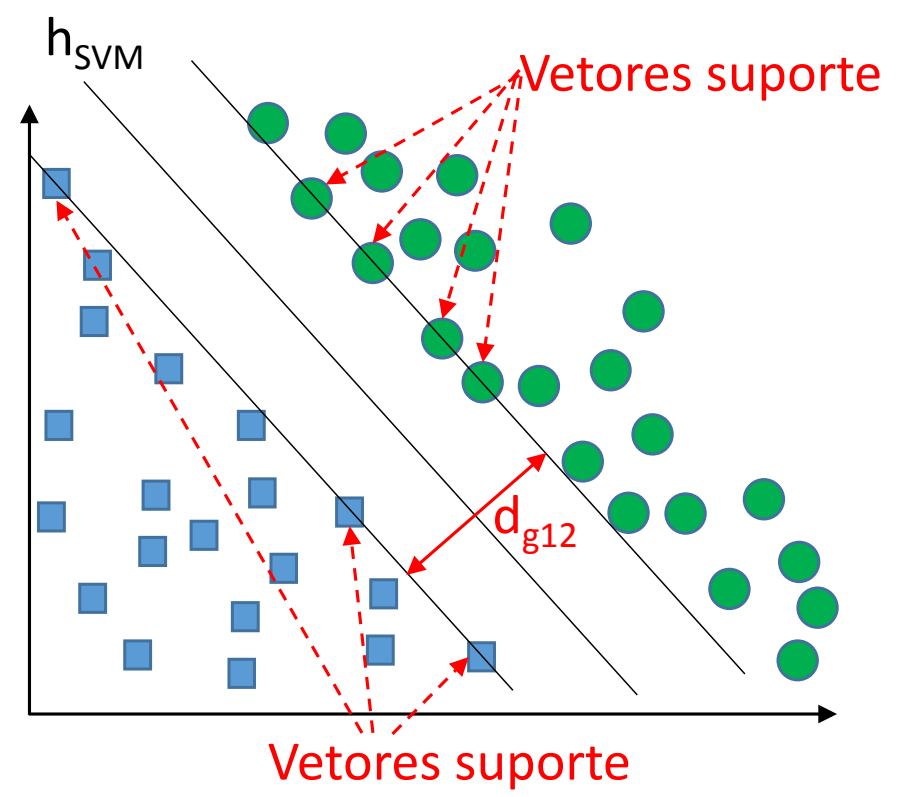

Figura 15 - Hiperplano do SVM.

O algoritmo perceptron tem a garantia de convergir apenas se os dados são linearmente separáveis. Um procedimento que não tem essa limitação é o discriminante de Fisher cujo objetivo é encontrar um hiperplano no qual a projeção dos dados é separada ao máximo. Sua função de custo otimizada está ilustrada na Equação 18.

$$
F=\frac{\left(m 1-m_{-1}\right)^{2}}{\sigma_{1}^{2}+\sigma_{-1}^{2}}
$$

Onde $m_{i}$ e $\sigma_{i}$ são respectivamente a média e o desvio padrão da função de saida indicada na Equação 19.

$$
\left(w \cdot x_{j}\right)+b: y_{j}=i
$$

Para as duas classes, $\mathrm{i}=1$ e -1 e $w$ é o vetor unitário perpendicular ao vetor suporte.

O poder computacional limitado de máquinas de aprendizagem lineares foi destaque na década de 1960 por Minsky e Papert. Em geral, aplicações complexas do mundo real exigem espaços de hipótese mais expressivas do que as funções lineares. Outra maneira de ver este problema é que frequentemente o conceito objetivo não pode ser expresso como uma combinação linear simples dos atributos dados, mas em geral requer que mais 
recursos abstratos dos dados sejam explorados. Várias camadas de funções lineares limitadas foram propostos como uma solução para este problema, e esta abordagem levou ao desenvolvimento de redes neurais multicamadas e algoritmos de aprendizagem como o back-propagation para treinamento desses tipos de sistemas. Um modelo de RNA multiperceptron pode ser visualizado na Figura 16.

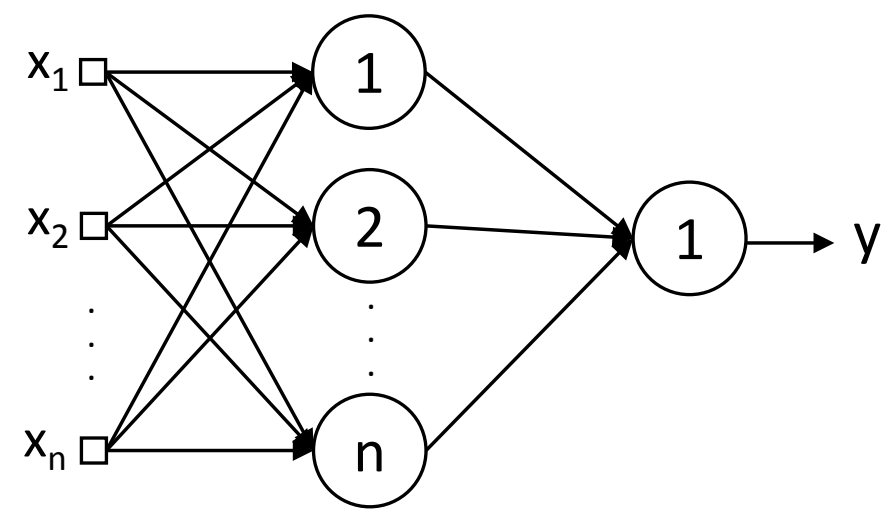

Figura 16 - Esquema de uma rede neural multicamadas perceptron. Fonte: Baseado em Silva, Spatti e Flauzino (2010).

As representações do kernel oferecem uma solução alternativa, projetando os dados em um espaço de alta funcionalidade dimensional para aumentar o poder computacional das máquinas de aprendizagem lineares. Outra característica do método do kernel é que os algoritmos de aprendizagem e teoria, em grande parte, podem ser dissociados dos aspectos específicos da área de aplicação, que devem simplesmente ser codificados para o projeto de uma função de kernel apropriado. Assim, o problema de escolher uma arquitetura para um aplicativo de rede neural é substituído pelo problema da escolha de um kernel adequado para o support vector machine. Modelos de kernels mais complicados podem ser construídos através da combinação de outros mais simples. O fato de que simplesmente mapear os dados para um outro espaço pode simplificar a tarefa é conhecida há muito tempo na aprendizagem de máquina, e tem originado uma série de técnicas para a seleção da melhor representação dos dados. As quantidades introduzidas para descrever os dados são geralmente chamadas de características, enquanto as quantidades originais, às vezes, são chamadas de atributos. A tarefa de escolher a representação mais adequada é conhecida como seleção de características. O espaço X é referido como o espaço de entrada, enquanto que $F=\{\phi(x): x \in X\}$ é chamado o espaço de características. 


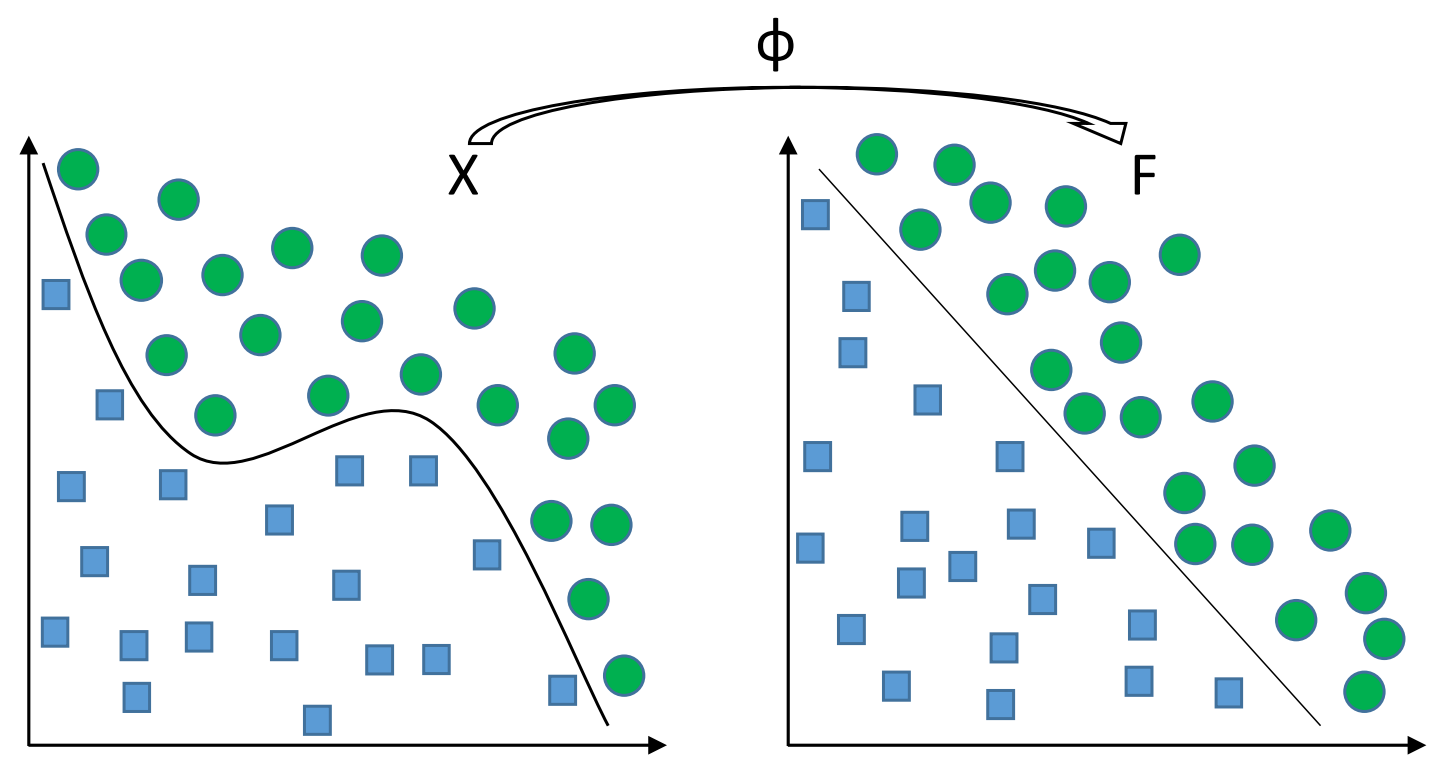

Figura 17 - Mapeamento de espaço X para F. Fonte: Baseado em Cristianini e Shawe-Taylor (2002).

A Figura 17 mostra um exemplo de uma característica de um mapeamento de espaço de entrada para um espaço característica bidimensional, onde os dados não podem ser separados por uma função linear no espaço de entrada, mas o podem no espaço de características.

Uma definição mais formal para o kernel seria que ele é uma função K, de tal forma que para todos os x e z, pertencentes a X como ilustrado na Equação 20.

$$
K(x, z)=\{\phi(x) \cdot \phi(z)\}
$$

onde $\phi$ é um mapeamento de X para um espaço de características F com a utilização do produto interno.

Uma consequência importante é que a dimensão do espaço de características não necessariamente afeta a computação. O número de operações necessárias para se calcular o produto interno através da avaliação da função de kernel não é, na maioria das vezes, proporcional ao número de características. A utilização de kernels torna possível mapear os dados implicitamente num espaço de características e formar uma máquina linear de tal espaço, potencialmente contornando os problemas inerentes computacionais para se avaliar o mapa de características Cristianini e Shawe-Taylor (2002).

Nos próximos parágrafos são apresentados alguns artigos que utilizam a técnica do support vector machine.

O artigo Cateni, Colla e Vannucci (2014) apresenta um método de reamostragem para problemas de classificação binárias em conjuntos de dados desbalanceados . Esses são frequentemente encontrados em muitas aplicações industriais: por exemplo, a ocorrência de um determinado defeito no produto, o diagnóstico de doenças graves em uma série de 
pacientes ou falhas em máquinas são eventos raros cuja detecção é de extrema importância. Neste trabalho um novo método de reamostragem é proposto combinando técnicas de sobre amostragem e subamostragem. Vários testes foram desenvolvidos com o objetivo de avaliar a eficiência do método proposto. Quatro classificadores baseados respectivamente em Support Vector Machine, Tree Decision, Self-Organizing Map e Classificadores Bayesianos foram desenvolvidos e aplicados para a classificação binária dos dados.

O SVM foi originalmente desenvolvido para trabalhar com classificação binária. O artigo Hsu e Lin (2008) mostra comparações entre métodos desenvolvidos para multiclasses.

Em Hsu, Chang e Lin (2010) é informado que a tarefa de classificação geralmente envolve separar os dados em conjuntos de treinamento e teste. Cada instância no conjunto de treinamento contém um valor-alvo (rótulo) e vários atributos ou características. O objectivo do SVM é produzir um modelo com base nos dados de treino que prevê os valores-alvo dos dados de teste.

Os SVMs fornecem uma nova abordagem para o problema de reconhecimento de padrões. Eles diferem radicalmente de abordagens comparáveis tais como as redes neurais. O algoritmo do SVM encontra sempre um mínimo global e sua interpretação geométrica simples proporciona um terreno fértil para uma investigação mais aprofundada. Um SVM é largamente caracterizado pela escolha do seu kernel BURGES (1998).

Em Lv Baoping Tang e Zhou (2016) um método de diagnóstico de falhas mecânicas utiliza o svm otimizado por um algoritmo genético.

Este artigo descreve um novo algoritmo chamado de SMO Platt (2000). A formação de um (SVM) requer a solução de um grande programação quadrática. O SMO quebra esse problema em uma série de menores problemas. A partir disso, a quantidade de memória necessária para SMO é linear relativamente ao tamanho do conjunto de treinamento, o que permite ao SMO lidar com grandes conjuntos de treinamento.

Este artigo combina técnicas de SVM com Hidden Markov Models Altun e Hofmann (2003). O maior benefício é a capacidade para lidar com características de sobreposição.

Em Cotter Shai Shalev-Shwartz (2013) é discutido como treinar SVMs com uma garantia ótima sobre o número de vetores de suporte.

LIBSVM é uma biblioteca para support vector machines (SVMs) desenvolvida desde 2000 Chang e Lin (2013). O objetivo é ajudar os usuários a aplicar facilmente SVM para suas aplicações. O LIBSVM ganhou grande popularidade em várias áreas que utilizam o SVM como classicação, regressão, e estimativa de distribuição.

Em Xu, Caramanis e Mannor (2009) é tratado sobre a robustez como que SVMs generalizam o aprendizado .

Vishwanathan e Murty (2002) apresenta um novo algoritmo eficiente e rápido que otimiza o número de cálculos do kernel devido à sua abordagem utilizada para construir os vetores-suporte.

Geralmente, se aplica o SVM usando aleatoriamente um conjunto de treinamento 
classificado com antecedência Tong e Koller (1998). Nesse artigo, um algoritmo foi desenvolvido para se escolher em quais casos as entradas devem ser classificadas. Esse método pode reduzir significativamente a necessidade de instâncias rotuladas.

Sen et al. (2008) trata de separação de superfícies em imagens médicas.

O artigo Tsochantaridis Thomas Hofmann e Altun (2004) trabalha com métodos para aprendizado de gramática supervisionado e reconhecimento de textos.

Em Bottou (2007) é explicado o funcionamento do algoritmo do SVM.

O artigo Bernardinisyx M. I. Jordany (2003) trabalha com desempenho de circuitos analógicos.

Andrews e Hofmann (2003) ilustra o estado da arte em técnicas de generalização de SVMs incluindo classificação não-linear através de kernels. Os experimentos foram realizados com dados da indústria farmacêutica e aplicações em imagens.

A função principal de um sistema de detecção de intrusão é analisar e predizer o comportamento de usuários Chen e Hsieh (2009). Esse comportamento é classificado como normal ou um ataque. Nesse artigo o SVM é utilizado para perfazer a classificação.

O artigo Sachdeva et al. (2016) tem por objetivo desenvolver um sistema interativo para ajudar os radiologistas na classificação de tumor cerebral multiclasse. Os resultados dos testes do primeiro conjunto de dados mostrou que a técnica de otimização de algoritmo genético aumentou a precisão global do SVM de 79,3\% para 91,7\% e da ANN de 75,6\% para 94,9\%. Resultados semelhantes são obtidos para o segundo conjunto de dados. A precisão global de SVM aumentou de $80,8 \%$ para $89 \%$ e a do ANN aumentou de $77,5 \%$ para 94,1\%. Dadas as características de classificação, que permitiram ao SVM, em alguns casos, apresentar resultados superiores à RNA, ele será considerado nessa tese. 


\section{Desenvolvimento da técnica para aplicação dos classificadores tipo RNA e SVM}

O objetivo desse capítulo é apresentar como foi desenvolvida a técnica para permitir a aplicação dos classificadores RNA e SVM aos dados de medição de nível e sua posterior recomendação de melhoria. Também informa como foram adquiridos os dados para os quatro cenários diferentes aos quais a técnica foi aplicada. Um teste preliminar era necessário para saber se a rede neural conseguiria ser treinada e depois generalizar o aprendizado, fazendo a detecção e classificação correta das fases diferentes do processo. Para tanto, foi preparado um ambiente controlado para esse aprendizado. Os dados também foram submetidos à classificação pelo SVM. Após o desenvolvimento da técnica a partir desse cenário preliminar, os procedimentos foram aplicados a um segundo cenário com os dados de uma aplicação real de uma usina de açúcar e etanol onde os dados foram colhidos pessoalmente pelo autor da tese e, na sequência, mais dois cenários reais de uma empresa no Japão e de uma outra do setor de óleo e gás foram ensaiados. Os arquivos .dat exportados pelo Radar Master dessas duas últimas corporações foram gentilmente cedidos pela Rosemount da Suécia, à qual o autor agradece.

Antes da explanação desses quatro cenários, alguns detalhes sobre o dimensionamento e instalação dos radares serão discutidos a seguir.

Se o radar foi instalado, ligado e não funciona corretamente, o primeiro passo é verificar se o modelo do radar está dimensionado adequadamente para os dados da aplicação. Neste âmbito, uma das informações mais importantes é verificar através do software Toolkit ${ }^{1}$ se o tamanho da antena é suficiente para se medir a faixa total da altura de medição que está relacionada também à constante dielétrica do fluido. Outras características importantes são o tipo e tamanho da conexão ao processo, faixas de operação de pressão e de temperatura, formato do tanque e o padrão de saída (protocolo 4-20 mA com HART,

\footnotetext{
${ }^{1}$ software indicado para o dimensionamento de radares, ilustrado e comentado no Apêndice A.
} 
Foundation Fieldbus, Profibus ou WirelessHart).

Caso o modelo não atenda, deve-se proceder a troca do radar ou da antena do mesmo. No caso do modelo do radar estar dimensionado corretamente, deve-se empreender a verificação da instalação conforme indicado no manual do instrumento. Por exemplo, deve-se checar se o radar está montado com antena colocada na posição vertical. Quando é utilizada a montagem em bocais, é uma boa prática que a boca da antena não fique dentro do bocal, isso pode gerar ecos dentro do bocal e atrapalhar a medição por perda de intensidade devido à reflexões internas no bocal. A antena deve estar bem fixada ao tanque e à eletrônica do radar. Os cabos de interligação do radar devem ter blindagem para evitar problemas de interferências. O invólucro do radar, caixas de junção e eletrodutos devem estar sem umidade e sem sinais de oxidação. A tensão elétrica também deve estar dentro dos padrões de funcionamento do radar segundo as exigências da aplicação quando em áreas classificadas e certificadas para prova à explosão ou com segurança intrínseca, que utilizam níveis diferentes de tensão de alimentação. O próximo passo é verificação da configuração. Deve se ter certeza de que o tag, a faixa da altura a ser medida, a geometria do tanque (cilindro vertical, horizontal, esférico...), a altura de referência (altura de onde o flange do radar está instalado), a constante dielétrica do fluido e se a aplicação tiver espuma, superfície turbulenta, variação rápida do nível, medição de sólidos ou alguma combinação desses características, os filtros descritos na seção denominada "Ajustes avançados" devem ser utilizados.

O ajuste da curva de limiar (threshold) é muito importante também. Os ecos com amplitudes abaixo desse limiar serão ignorados pelo software do radar. Normalmente, os radares vem de fábrica configurados. Mas nem sempre as condições descritas pelo usuário são exatamente as configuradas. Algumas vezes, isso ocorre porque entre o processo de compra e a instalação podem ocorrer alterações mecânicas no tanque como soldagens, instalação de aparatos como serpentinas para trocadores de calor (ou resfriadores), pás de agitadores, entre outros. Existe a possibilidade, também, de que o radar tenha sido comprado como sobressalente e fique no almoxarifado do usuário para substituição de algum ponto de aplicação de medição e é comum que os pontos de medição tenham características diferentes como outros formatos de tanque, outras alturas a medir, outros fluidos e condições de processo. Nesses casos, os radares devem ser reconfigurados.

Outra possibilidade é que depois do radar ter sido corretamente instalado e configurado, as condições de processo como pressão, temperatura, fluido do processo, sejam alteradas. Com isso, pode ser que a antena do radar fique contaminada por algum produto, vapor ou sólidos em suspensão passam a atenuar a amplitude do sinal recebida pela antena do radar. Nesse caso, o reajuste do threshold será necessário. Para esses casos, a análise dos plots registrados pelo Radar Master é fundamental para ajudar a descobrir os problemas e é a base desse trabalho para a recomendação de como se pode otimizar a medição de nível. 
A Figura 18 ilustra os procedimentos realizados para o teste da RNA.

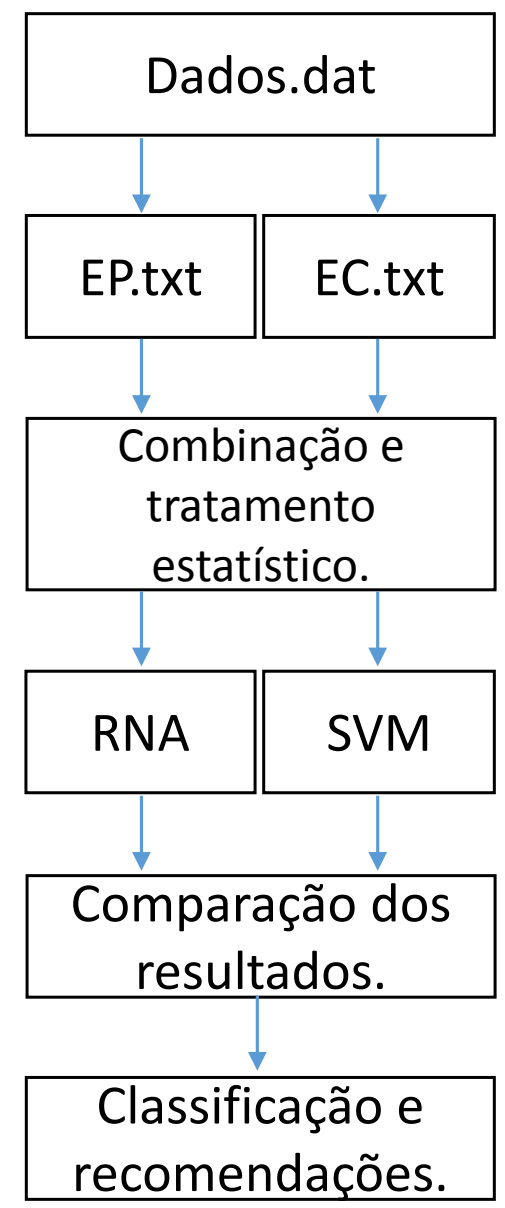

Figura 18 - Plano de trabalho.

Com o radar instalado, um HART modem é interligado à sua borneira e a um computador com o software do radar. Após esse procedimento, o software é iniciado e os dados de nível são adquiridos e mostrados em forma gráfica com informações sobre a amplitude e distância dos ecos. Ou seja é como o radar detecta o valor do nível da superfície do fluido e de outras estruturas internas ao tanque analisando os ecos que retornam a partir do envio das micro-ondas com frequência de $26 \mathrm{GHz}$. O tempo de registro de cada frame é variável porque depende da altura a ser medida. Normalmente varia de 5 a 35 segundos. Para a medição preliminar citada neste trabalho, o tempo entre cada frame foi da ordem de 15 segundos. Depois de alguns deles amostrados, é possível acompanhar a passagem de frame a frame para se analisar o comportamento das mudanças de amplitude e distância com relação ao tempo. Após exportar o arquivo "nome.dat" pelo Radar Master, os dados devem ser importados pelo PlotViewer que é um software integrante no pacote do Radar Master e permite salvar os dados em formato de texto. A partir desse arquivo texto, os dados são trabalhados pelo Matlab com análises estatísticas e treinamentos supervisionados de redes neurais para a detecção dos diversos tipos de problemas da medição. Os 


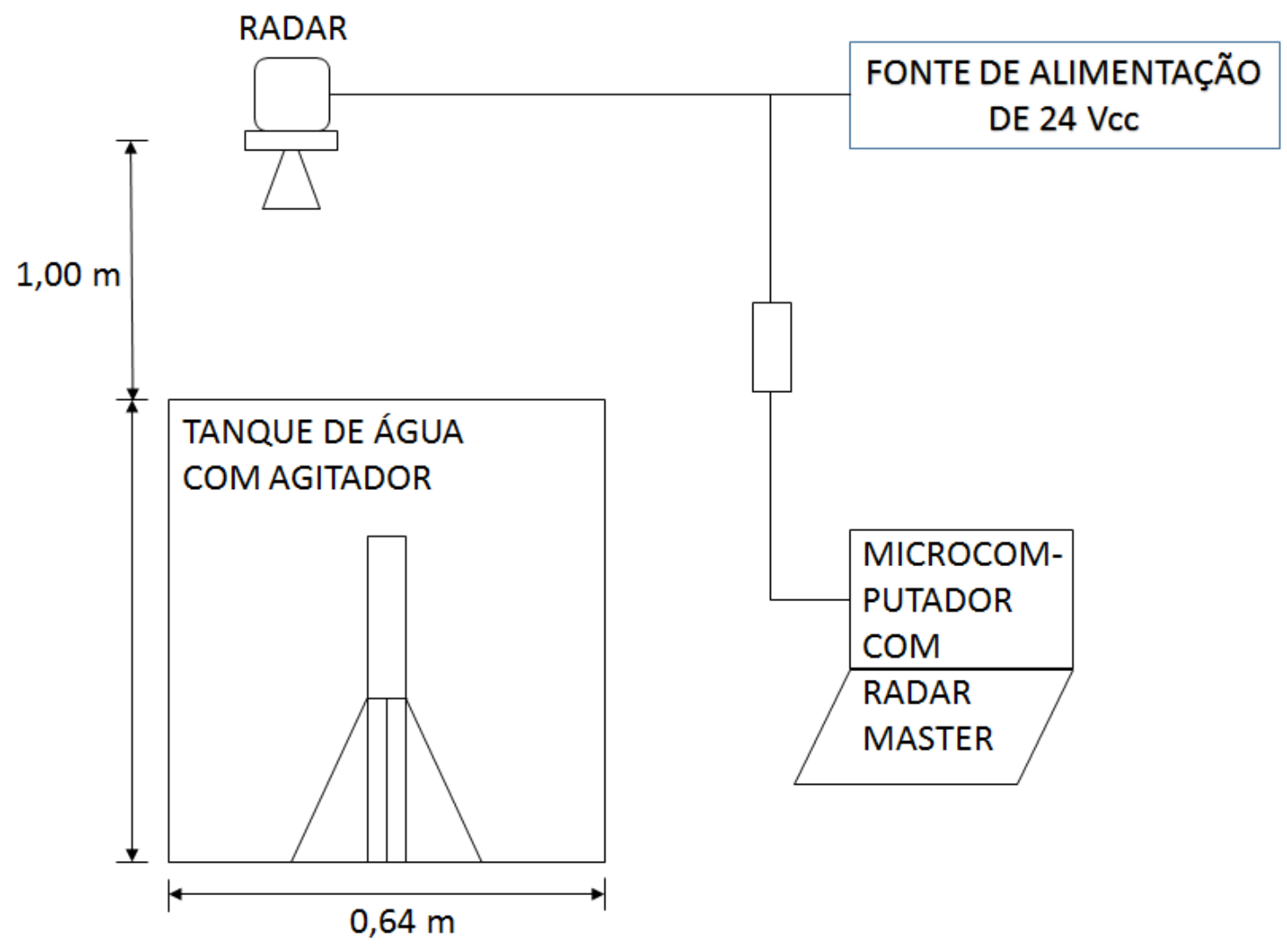

Figura 19 - Montagem da bancada de aquisição de dados.

mesmos dados pré-processados foram aplicados ao Weka WITTEN (2014) para verificação se a RNA ou o SVM fariam uma melhor classificação. O melhor resultado, seja o proveniente da RNA ou do SVM, é tomado e combinado com os dados de processo e da instalação. Partindo-se desse cruzamento de informações é possível fazer recomendações para a otimização do desempenho da medição de nível com o radar.

\subsection{Primeiro cenário}

Na Figura 19 é ilustrada a montagem da bancada experimental de aquisição de dados.

Como informado no início desse capítulo, foi necessário uma aplicação em um ambiente controlado para se desenvolver a técnica. Para esse fim, um radar foi instalado em um tanque de água com um agitador no qual tinha se conhecimento passo a passo das simulações de enchimento do tanque, período de superfície calma durante os molhos e período de agitação quando as pás se movimentavam e produziam uma superfície turbulenta. Foi simulado, também, a colocação de espuma densa na água para simular uma produção de espuma que ocorre em vários processos industriais e, por fim, o processo de esvaziamento do tanque quando o conteúdo da água dentro do tanque é expelida via uma bomba de água. 
Em outra fase de aquisição de informações, foi simulada a contaminação de espuma na antena do radar. Foi colocada, aproximadamente $2 \mathrm{~cm}$ de espuma densa na antena. Isso ocorre anormalmente em algumas aplicações quando a espuma sobe até onde se encontra a antena do radar.

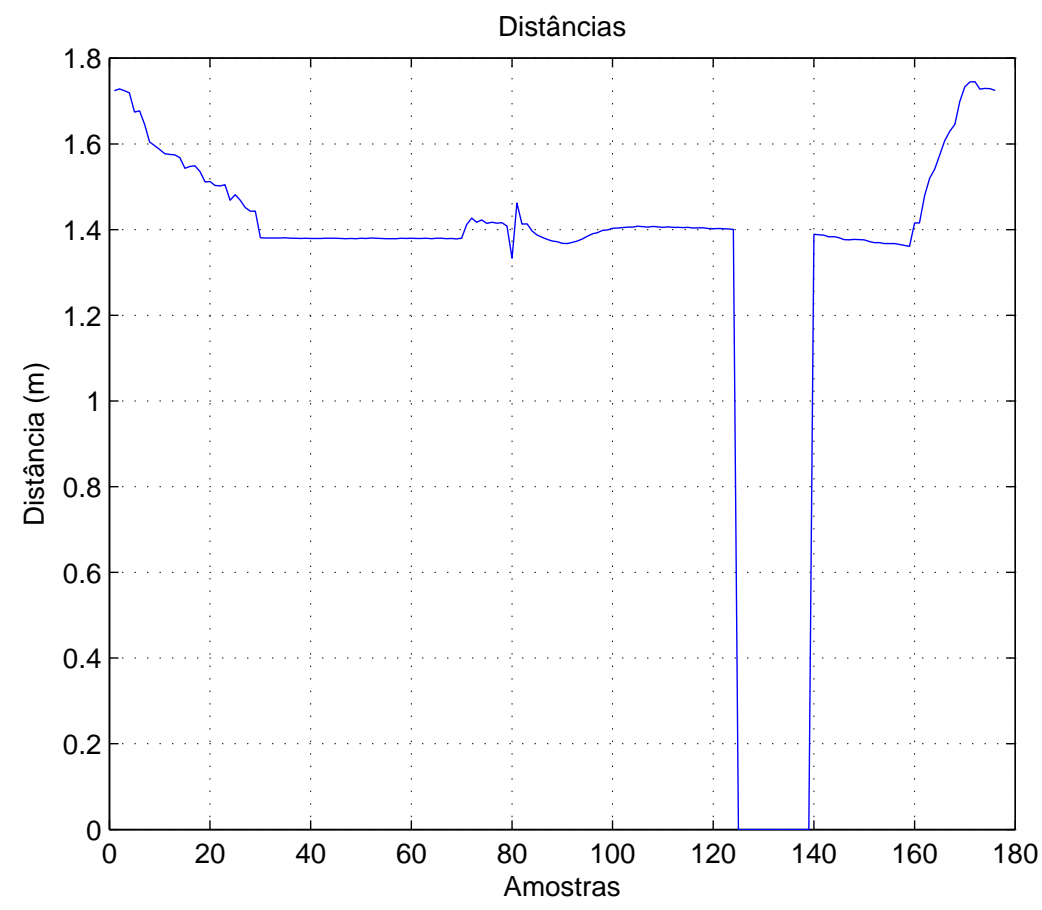

Figura 20 - Gráfico da distância pelas amostras.

Após armazenar os gráficos para a situação exposta, uma quantidade menor de espuma, que recobria por volta de uns $30 \%$ da área de saída da antena foi introduzida para uma outra condição de aquisição de dados.

Na Figura 20 é ilustrado o gráfico da distância ao longo das amostras. Para o primeiro cenário, os frames de 1 a 29 representam dados adquiridos durante o enchimento do tanque. Esses frames estão representados nos gráficos como as amostras de número 1 até 29. As amostras de 30 até 69 representam a superfície calma, de 70 a 79, os dados são relacionados à fase de turbulência devido à agitação das pás da máquina. A faixa das amostras de 80 até 124 retratam a fase onde foi colocada espuma na água. Depois, essa espuma foi retirada e parte dela foi adicionada na antena. Essa fase está representada entre as amostras 125 até a 139. A partir da amostra 140 até a 159, parte da espuma foi retirada. As amostras 160 até a 176 são dados representativos do esvaziamento do tanque.

É possível verificar que a distância diminui de 1,72 m para 1,38 m até o frame 30 (fase de enchimento) permanecendo nesse patamar, sem alterações significativas até o frame 69 (fase de superfície calma). A amplitude do sinal na Figura 21, começa em torno de 1600 $\mathrm{mV}$, depois cai para próximo dos $500 \mathrm{mV}$ devido à turbulência da superfície por efeito do 


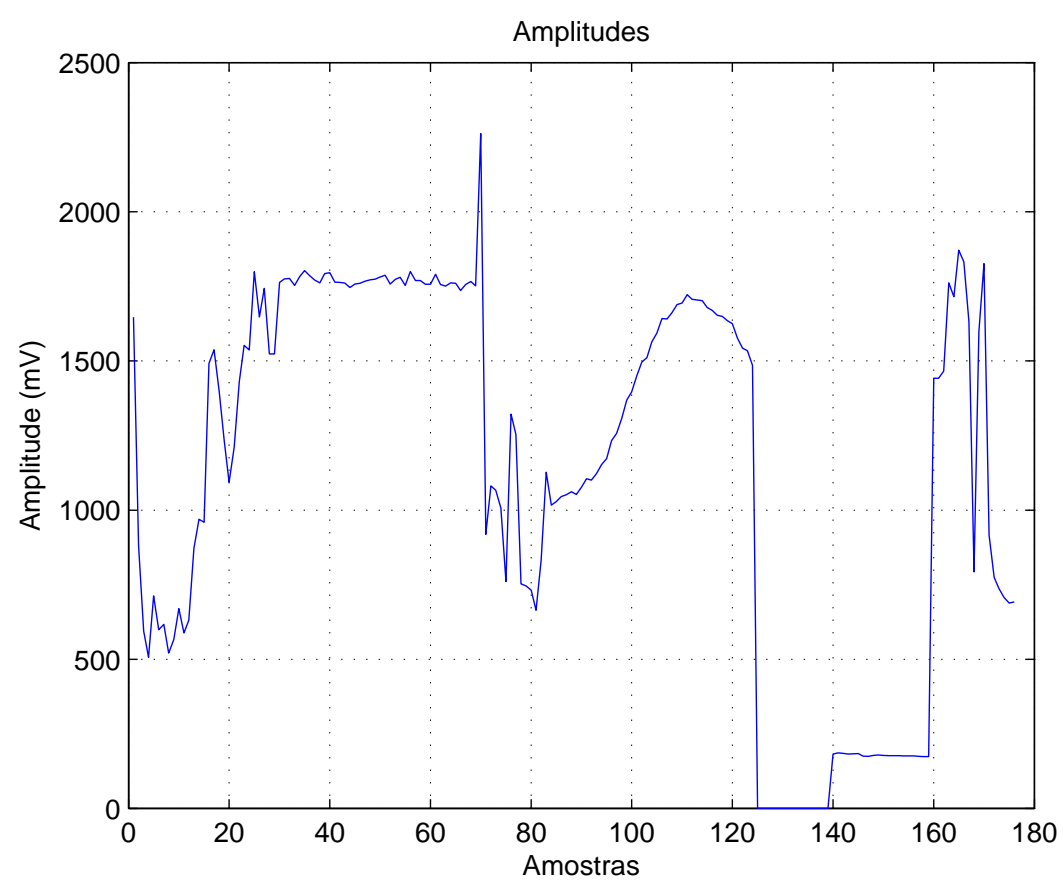

Figura 21 - Gráfico da amplitude pelas amostras.

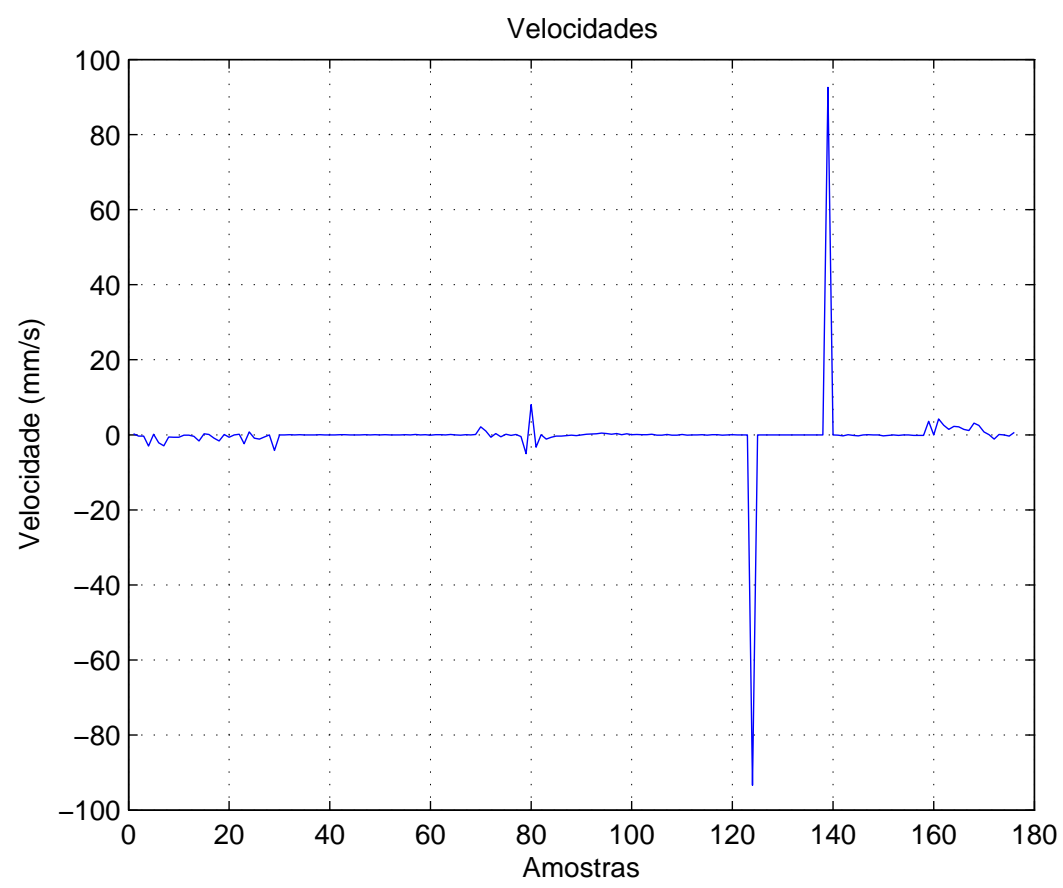

Figura 22 - Gráfico da velocidade pelas amostras.

esguicho da entrada da água. Então, vai aumentando até uns $1500 \mathrm{mV}$ próximo à amostra 17. Essa subida se deve à uma combinação da diminuição da distância entre a antena do radar e o liquido, o que aumenta a força do sinal do eco, mas com uma grande variação de 
amplitude entre as amostras devido à superfície continuar turbulenta. Entre as amostras 30 e 69, a amplitude permaneceu com poucas alterações devido à superfície calma.

A partir do frame 70 há uma variação da superfície que está turbulenta até o frame 79 (fase de agitação) quando há adição de espuma na superfície. Esse aumento de aproximadamente $3 \mathrm{~cm}$ na superfície é detectado pelo radar quando se trata de espumas densas. Quando há espuma muito aerada como as que são feitas por bolhas de sabão, elas são praticamente invisíveis pelas micro-ondas que a atravessam e medem o nível do liquido abaixo da espuma. Nessa fase de agitação, a amplitude cai e fica muito variável e quando é colocada a espuma, com o passar do tempo, devido à tendência da espuma formar uma superfície horizontal e calma, a amplitude vai aumentando até $1831 \mathrm{mV}$ na amostra 124.

No frame 125, tem-se a retirada da espuma do liquido e parte dessa espuma foi aplicada diretamente na antena com cerca de $2 \mathrm{~cm}$ de espessura. Isso formou uma barreira para as micro-ondas e o radar não consegue fazer a medição até o frame 139 (fase de espuma intensa na antena). Nessa fase citada, a distância e a amplitude do sinal permanecem zeradas. A partir do frame 140 até o 158, boa parte da espuma é retirada, permitindo-se o funcionamento do radar (fase com pouca espuma na antena). Nessa fase, a distância fica próximo dos 1,37 $\mathrm{m}$ diminuindo uns $2 \mathrm{~cm}$, provavelmente devido à algum pequeno vazamento do tanque. A amplitude fica baixa entre 173 e $180 \mathrm{mV}$ nessa fase, indicando que grande parte do sinal é absorvido pela espuma na antena. Entre as amostras 160 e 176, o nível baixa, a distância aumenta de 1,41 para 1,72 cm enquanto a amplitude varia bastante devido à turbulência causada pela bomba de água, com tendência a reduzir o seu valor devido ao aumento da distância entre a antena e o fluido. O gráfico da velocidade, na Figura 22, tem pouca variação até próximo da amostra 80, onde devido à turbulência maior da agitação apresenta um pico de $8,1 \mathrm{~mm} / \mathrm{s}$. Depois na amostra 124 apresenta um vale de $93,4 \mathrm{~mm} / \mathrm{s}$ e na amostra 139, um pico de 92,6 mm/s. Esses últimos valores altos ocorreram devido à colocação da espuma e sua retirada em um intervalo de uma amostra.

Entre o último valor da amostra $124(1,40 \mathrm{~m})$, quando o tanque foi desligado para se retirar a espuma da superfície do liquido e colocada na antena, e na próxima amostra 125, o valor registrado de nível foi zero porque o radar estava impedido de fazer a medição devido à obstrução das micro-ondas pela espuma. Essa diferença toda de -1400 mm num tempo do frame de aproximadamente 15 segundos, que não é real para o processo, fez com que o valor da velocidade fosse tão baixa de quase $-100 \mathrm{~mm} / \mathrm{s}$. O mesmo se dá para a transição da amostra $139(0 \mathrm{~m})$ para a $140(1,39 \mathrm{~m})$ no mesmo tempo de $15 \mathrm{~s}$, que gerou uma velocidade de quase $100 \mathrm{~mm} / \mathrm{s}$, também não realística.

As Figuras 20, 21 e 22 da distância, amplitude do sinal do eco e da velocidade, que foram mostradas em relação às amostras, estão representadas em relação ao tempo no Apêndice C. Essas figuras foram desenvolvidas em relação ao tempo para uniformizar os gráficos visto que os outros 3 cenários utilizam os gráficos nesse padrão. As figuras a seguir sobre os pré-processamentos estatísticos também estão graficadas em relação às 

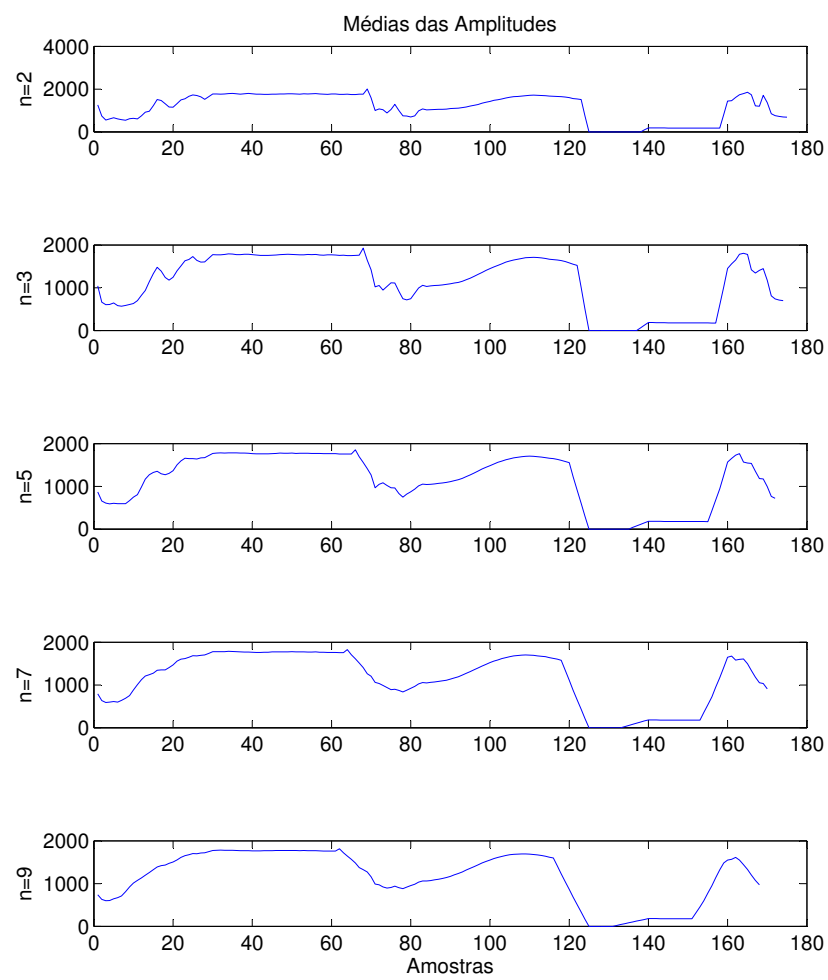

Figura 23 - Média das amplitudes.
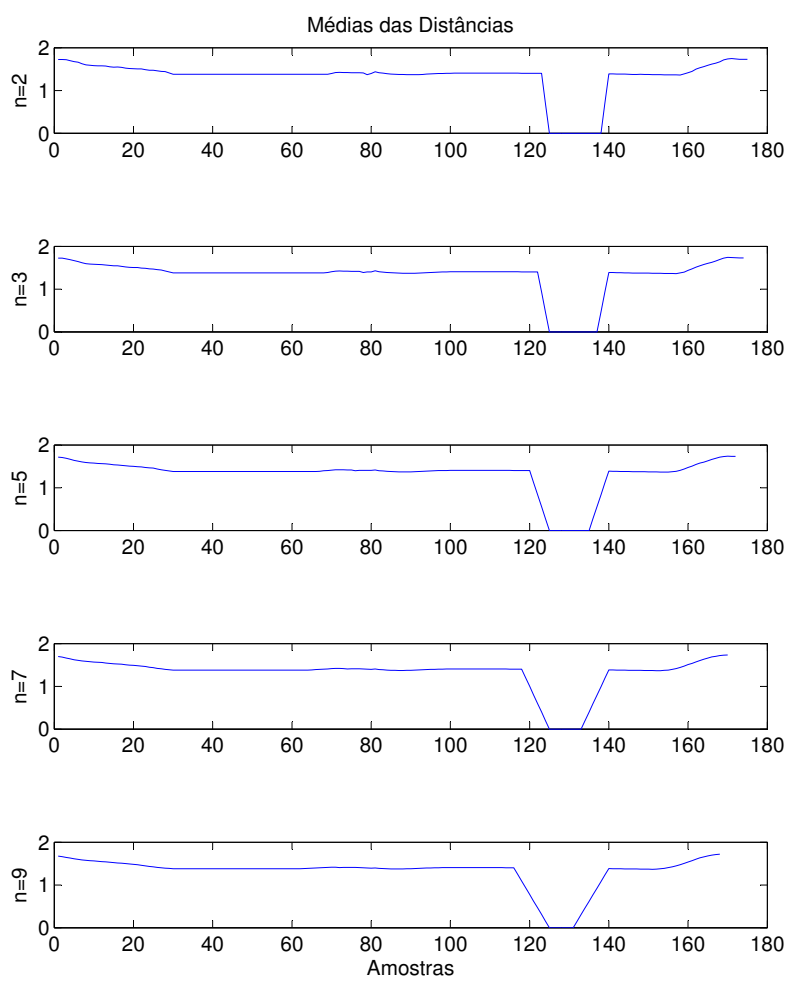

Figura 24 - Média das distâncias. 

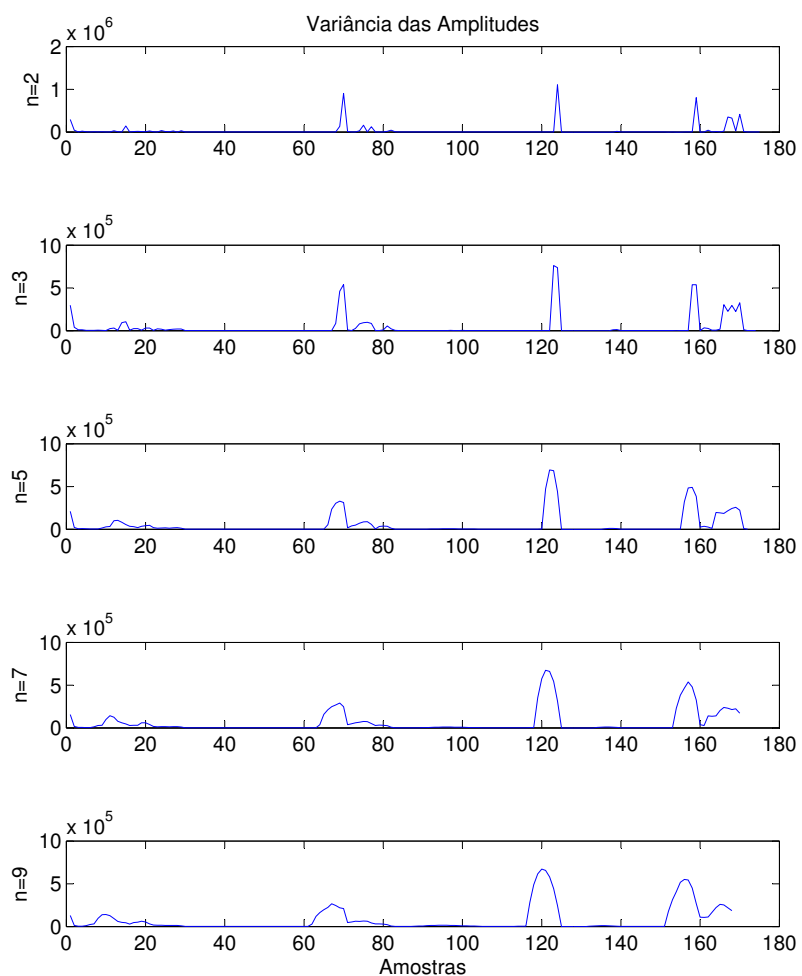

Figura 25 - Variância das amplitudes.
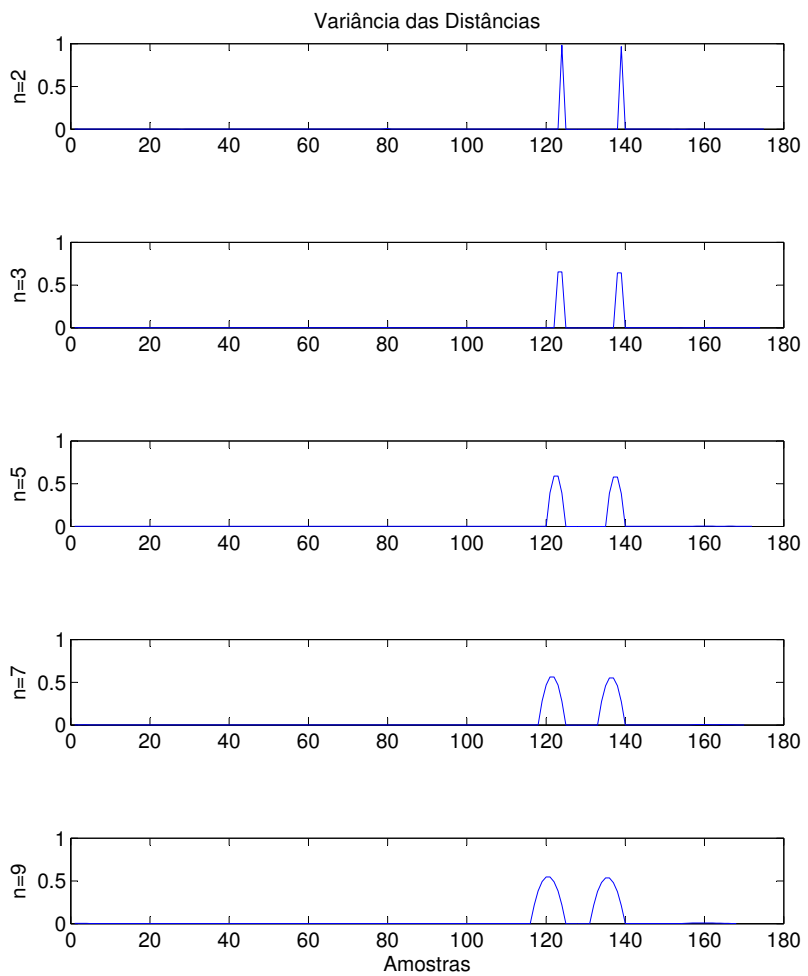

Figura 26 - Variância das distâncias. 

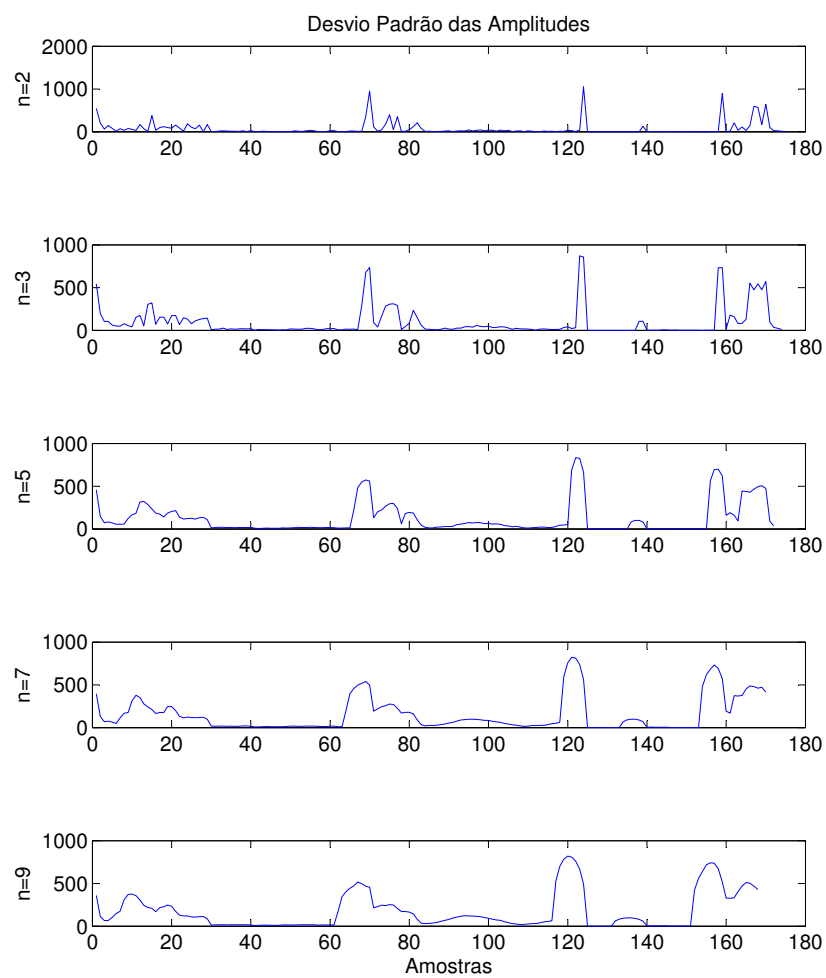

Figura 27 - Desvio padrão das amplitudes.
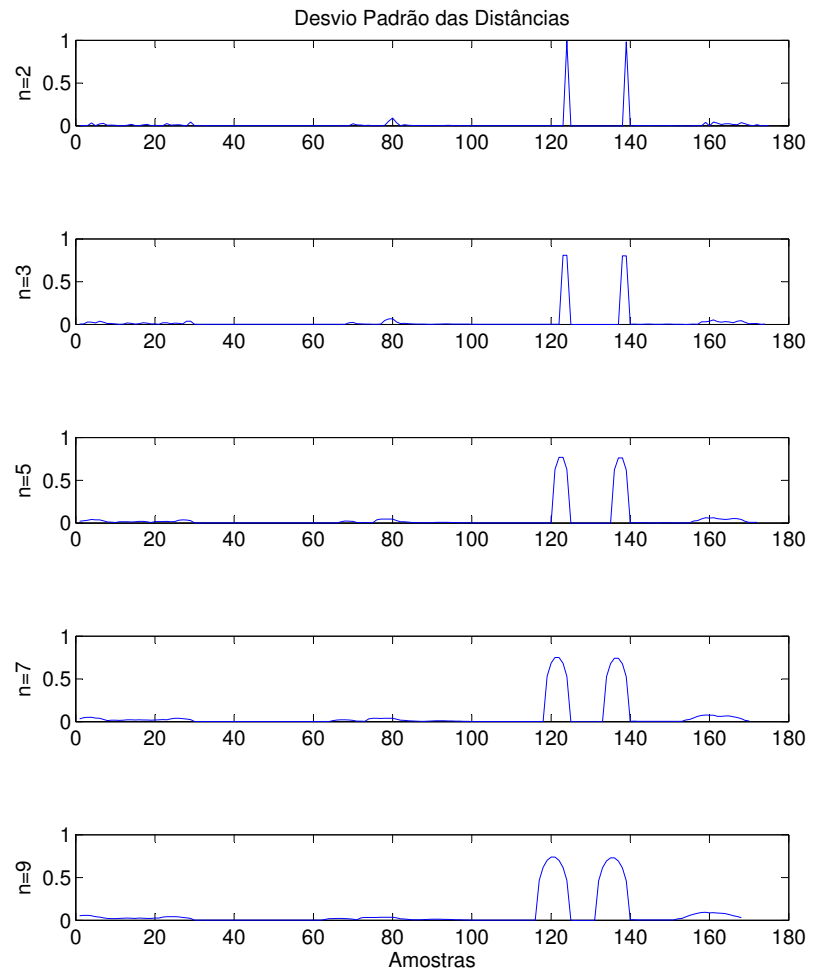

Figura 28 - Desvio padrão das distâncias. 

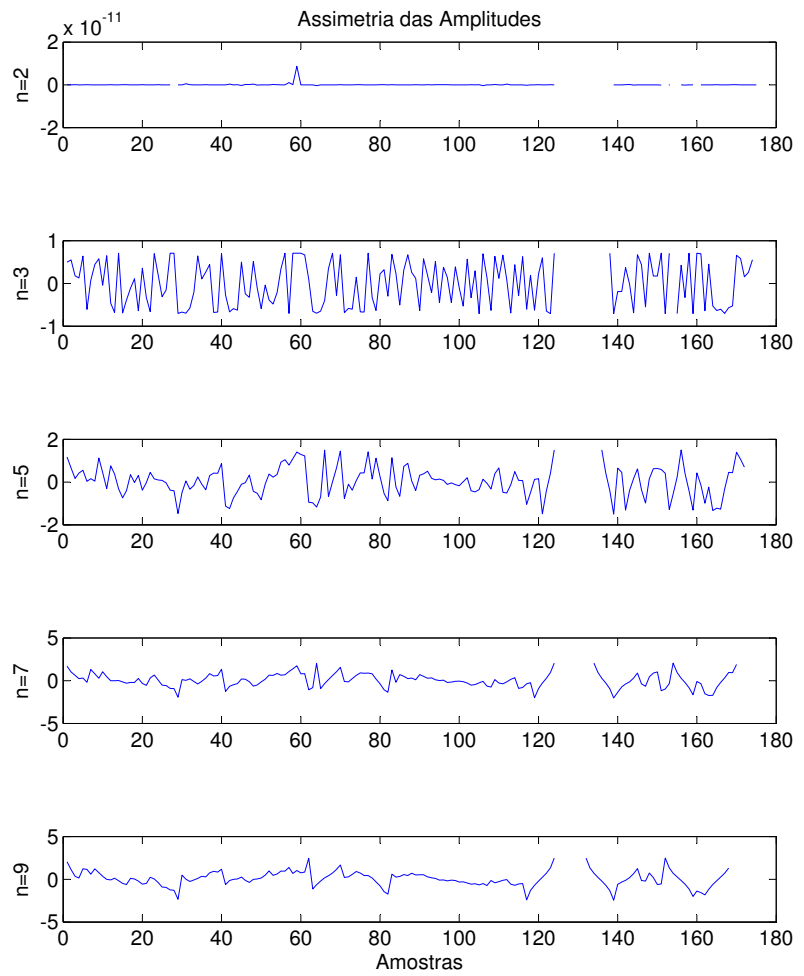

Figura 29 - Assimetria das amplitudes.
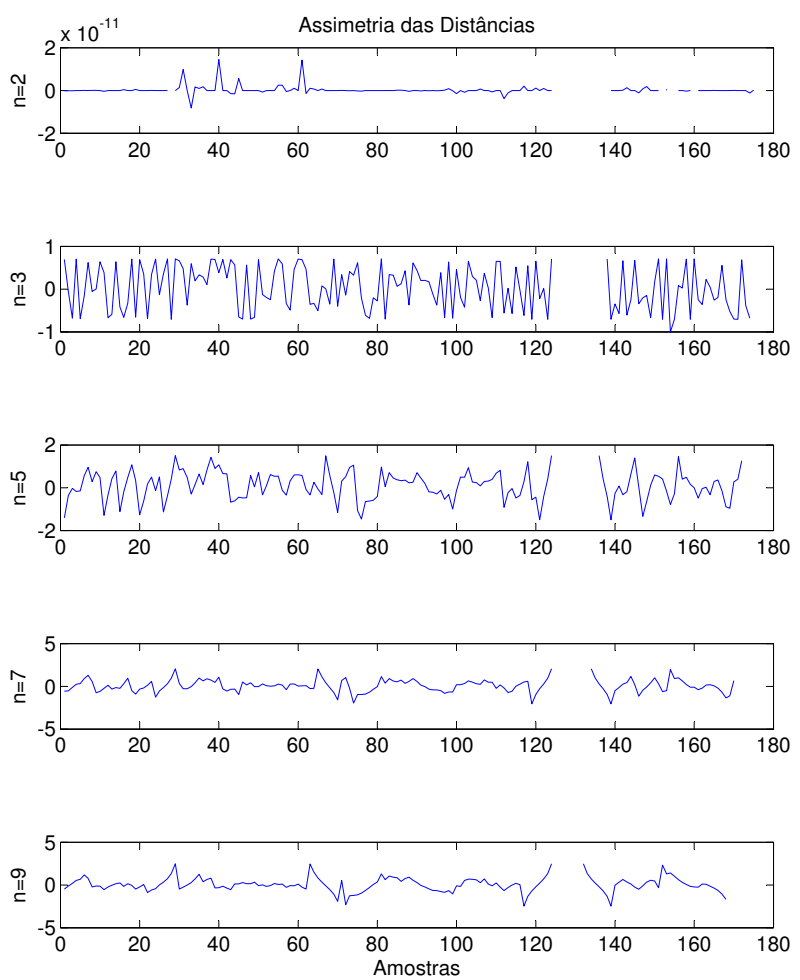

Figura 30 - Assimetria das distâncias. 

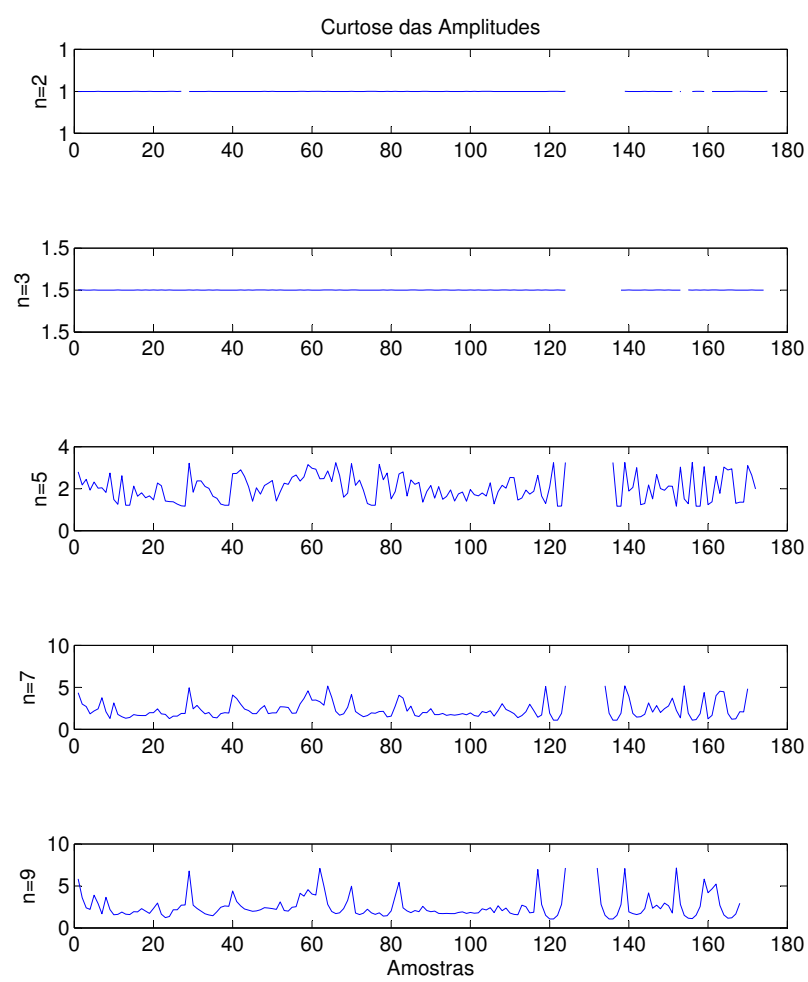

Figura 31 - Curtose das amplitudes.
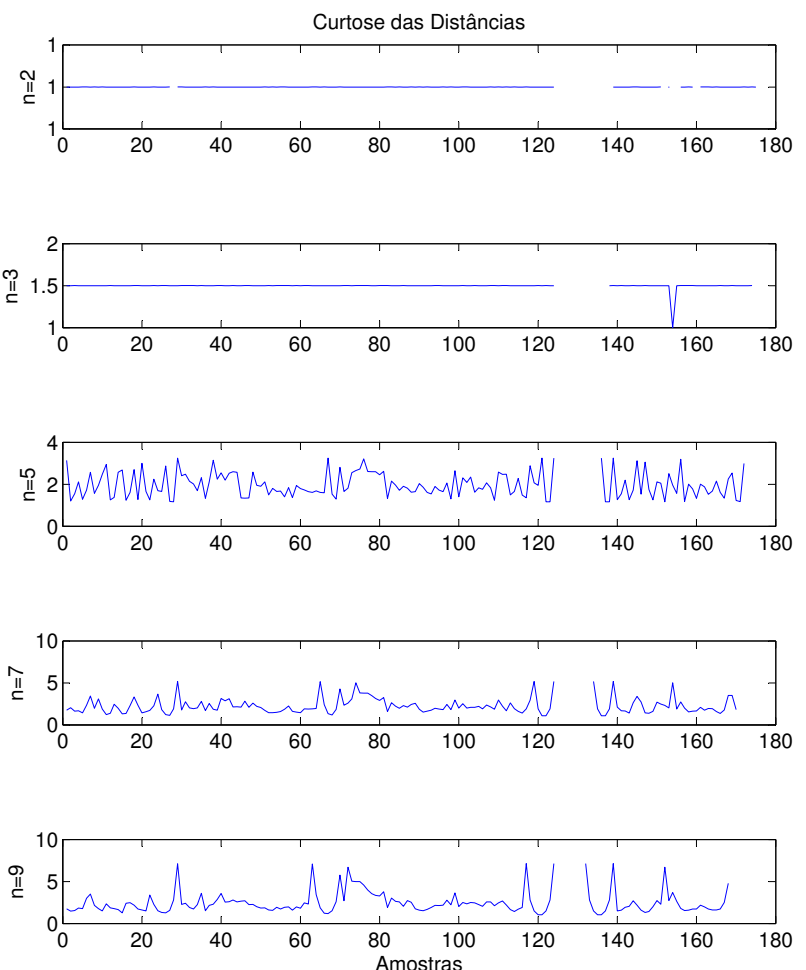

Figura 32 - Curtose das distâncias. 
amostras, razão pela qual foi mantido esse padrão para as figuras anteriores.

A Figura 23 até a Figura 32 representam as análises estatísticas principais dos dados analisados com janelas de 2, 3, 5, 7 e 9 elementos. A letra $\mathrm{n}$ ao lado esquerdo dos gráficos se refere ao número dessas amostras por janela.

Analisando os gráficos da Figura 23 e da Figura 24 é possível observar que os gráficos tem um comportamento muito semelhante aos gráficos de amplitude e distância ao longo das amostras com a diferença de que aparecem mais atenuados, sem tantos picos como os originais devido ao efeito da média. Esse amortecimento dos picos é mais pronunciado com o número maior de elementos da janela.

Os gráficos da variância e do desvio padrão apresentaram, como era de se esperar, valores de pico quando houve maior turbulência e quando houve a adição e a retirada da espuma na antena.

Os gráficos de assimetria e curtose apresentaram valores maiores para as janelas com um maior número de elementos, mas não foi possível uma analogia direta com o processo, excetuando-se o trecho em que tanto a amplitude quanto a distância permaneceram nulas.

Embora não tenha sido possível essa interpretação visual de associação com os dados de processo e os valores de assimetria e curtose, esses últimos foram guardados temporariamente para se checar se seria possível treinar a rede com os outros valores, sejam eles diretos da aquisição dos plots ou do processamento estatísticos dos dados. Caso não se obtivesse êxito com os valores de média e desvio padrão, esses valores de assimetria e curtose seriam reconsiderados porque talvez exista alguma característica importante que possa ser utilizada no treinamento da RNA ou do SVM.

O total de 176 amostras foram aleatoriamente divididas entre 158 para o treinamento e 18 para os testes.

A partir da técnica trabalhada no primeiro cenário, sua base foi desenvolvida para três outros cenários nos quais os dados são provenientes de aplicações reais na indústria.

\subsection{Segundo cenário}

Para esse segundo cenário os dados do radar foram adquiridos em uma visita à usina de etanol e açúcar. Esse usuário tem alguns radares instalados no campo e um deles, instalado no tanque de estágio de evaporadores, tinha apresentado problemas de medição devido à uma concentração intensa de vapor e espuma em certos períodos. Esse radar foi realocado para uma garrafa, que é o nome conhecido para um tubo de quatro polegadas de diâmetro posicionado ao lado do tanque principal e interligado à este. Pelo princípio dos vasos comunicantes, o nível é o mesmo em ambos os tanques sendo que o radar dentro dessa garrafa fica menos suscetível à vapores e turbulência. Dessa forma, o nível do liquido dentro da garrafa é medido e se infere o nível dentro do tanque principal. A aquisição de dados durou aproximadamente 7 horas. O mesmo laptop do primeiro cenário 
foi utilizado com o Radar Master instalado e interligado ao painel através de um HART modem diretamente conectado na borneira de onde partia o par de cabos que sobe para a interligação do radar no topo da garrafa.

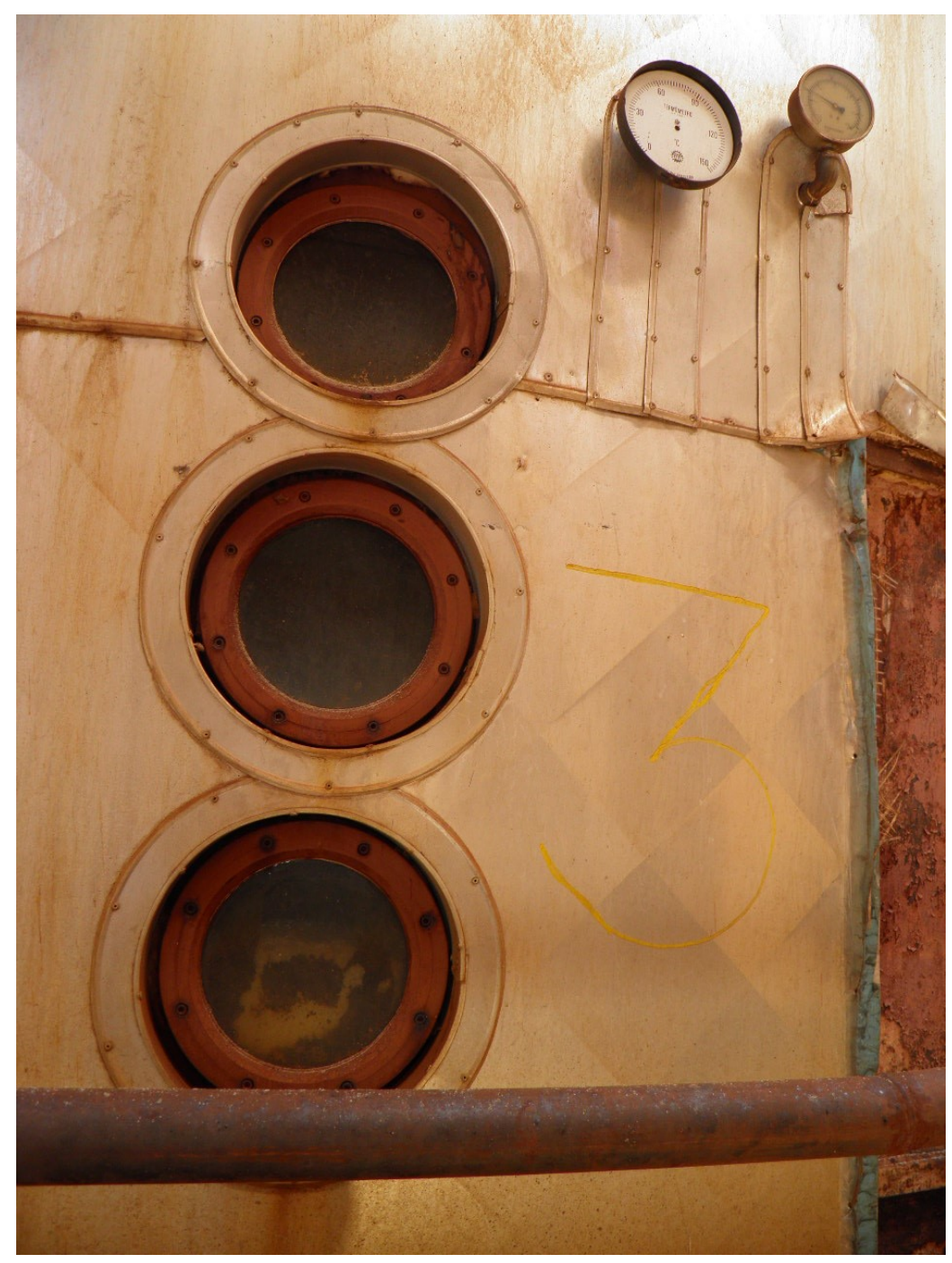

Figura 33 - Tanque da seção do evaporador da usina.

Durante o tempo em que os dados eram adquiridos, as ocorrências de volumes maiores de espuma ou vapores mais intensos observados no processo foram acompanhadas e anotadas através dos visores do tanque.

Na Figura 33 é ilustrado o tanque que foi monitorado no setor de evaporadores da usina do segundo cenário.

Os gráficos da distância, amplitude do sinal recebido pelo radar e a velocidade de variação da distância foram trabalhados no Matlab e estão disponíveis nas próximas figuras.

Na Figura 34 é ilustrado o gráfico da distância medida versus tempo. O valor inicial da distância é de $6,06 \mathrm{~m}$, apresenta pequenas alterações chegando a um pico de 6,07 m 


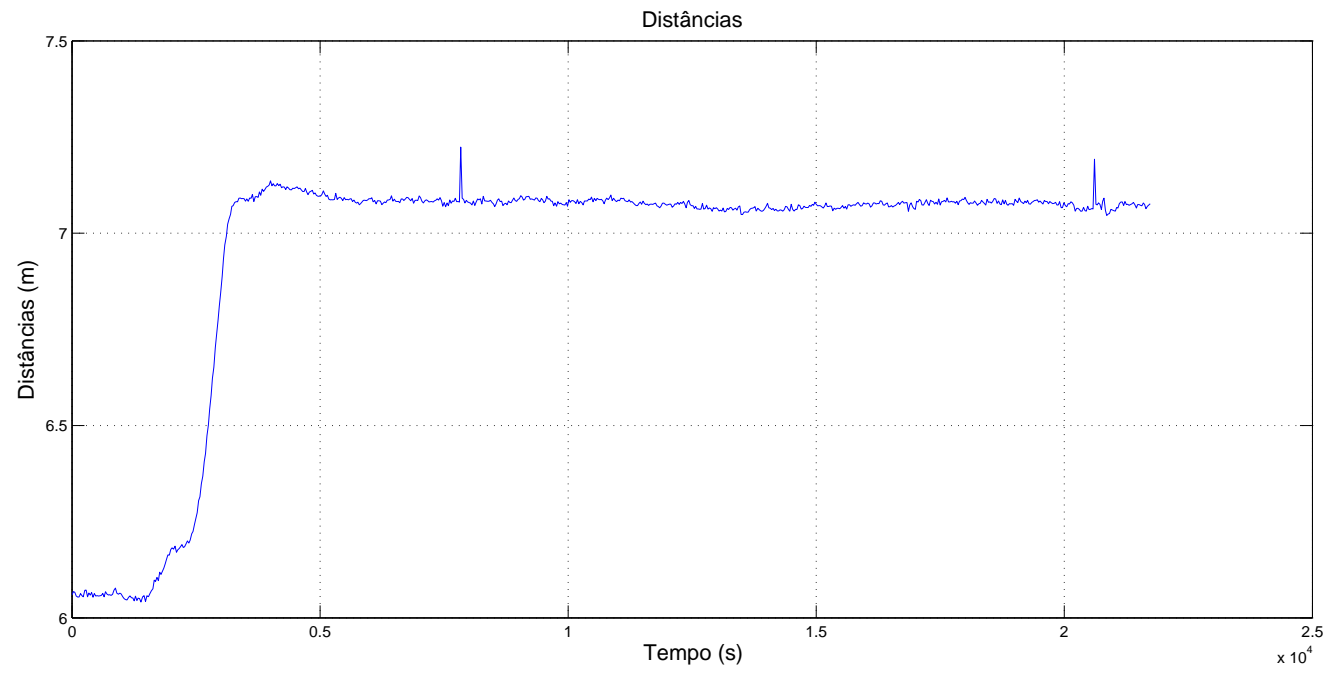

Figura 34 - Gráfico da distância pelo tempo.

depois de $876 \mathrm{~s}$, depois apresenta uma queda até o valor de 6,04 m em $1481 \mathrm{~s}$. A partir desse ponto inicia uma ascensão acentuada até 7,14 m em 4002 s. Depois disso apresenta uma queda com um pouco de oscilação da distância e tem um pico de 7,22 m no tempo de $7836 \mathrm{~s}$. Na sequência, há várias pequenas alterações até outro pico de 7,19 m no tempo de 20610 s. Então, a curva cai para um patamar de 7,06 m e no tempo de 21730 s é encerrado com o valor de 7,07 $\mathrm{m}$.

A Figura 35 retrata a informação gráfica da amplitude do eco recebida pelo radar ao longo do tempo. O valor de início da amplitude é de $1078 \mathrm{mV}$. Esse valor sobre rapidamente para $1516 \mathrm{mV}$ depois de $57 \mathrm{~s}$. Apresenta fortes oscilações com valores mínimos próximos a $1712 \mathrm{mV}$ em $1104 \mathrm{~s}$ chegando a $2270 \mathrm{mV}$ em 1895 s. Continua com fortes oscilações com o valor de vale em $818,3 \mathrm{mV}$ no tempo de 3722 s. Apresenta tendência de subida até o ponto de $1692 \mathrm{mV}$ em $4871 \mathrm{~s}$. Depois disso continua com um padrão de alta oscilação passando pelos pontos de $552,3 \mathrm{mV}$ em 5122 s, $1735 \mathrm{mV}$ em 8176 s, $1057 \mathrm{mV}$ em 10670 s, 1678 mV em 12180 s, 768,3 mV em 13600 s, 1841 mV em 16100 s, 448 mV em $20610 \mathrm{~s}$ e finaliza com o valor de $1302 \mathrm{mV}$ no tempo de $21730 \mathrm{~s}$.

Na Figura 36 é ilustrado o gráfico da velocidade da distância contra o tempo. O primeiro valor de velocidade do gráfico é de $0,32 \mathrm{~mm} / \mathrm{s}$. Apresenta uma oscilação até o valor de $-0,54 \mathrm{~mm} / \mathrm{s}$ em $2077 \mathrm{~s}$ e então apresenta uma tendência de subida até o valor de $1801 \mathrm{~mm} / \mathrm{s}$ em $2859 \mathrm{~s}$. Após esse trecho cai até o valor de $-0,59 \mathrm{~mm} / \mathrm{s}$ em $3635 \mathrm{~s}$, segue com poucas alterações de valores até um pico e um vale repentinos de $5502 \mathrm{~mm} / \mathrm{s}$ em 7810 s e $-4921 \mathrm{~mm} / \mathrm{s}$ em $7836 \mathrm{~s}$. Na sequência, apresenta pequenas alterações até um novo pico/vale de menores proporções que o anterior indicando 4,47 mm/s em $20580 \mathrm{~s}$ e $-4,19 \mathrm{~mm} / \mathrm{s}$ em $20610 \mathrm{~s}$, retornando às oscilações mais baixas até o valor final de 0,33 $\mathrm{mm} / \mathrm{s}$ em $21730 \mathrm{~s}$. 


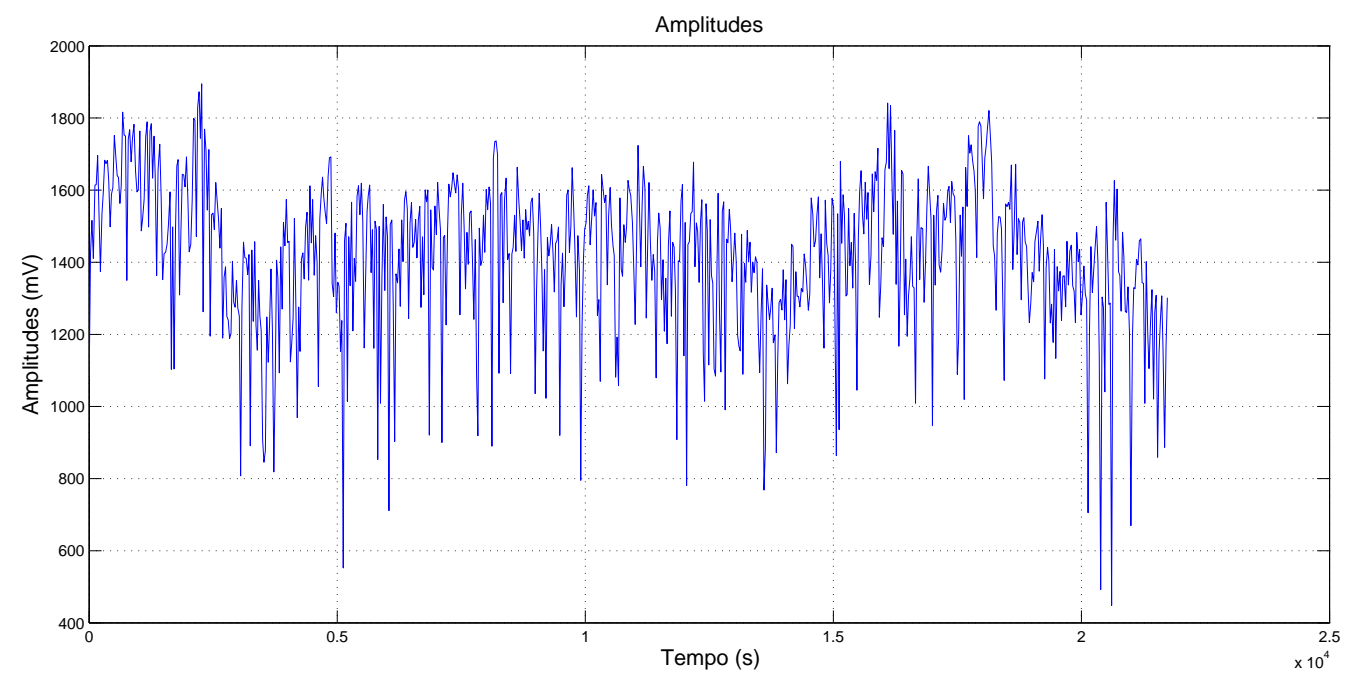

Figura 35 - Gráfico da amplitude pelo tempo.

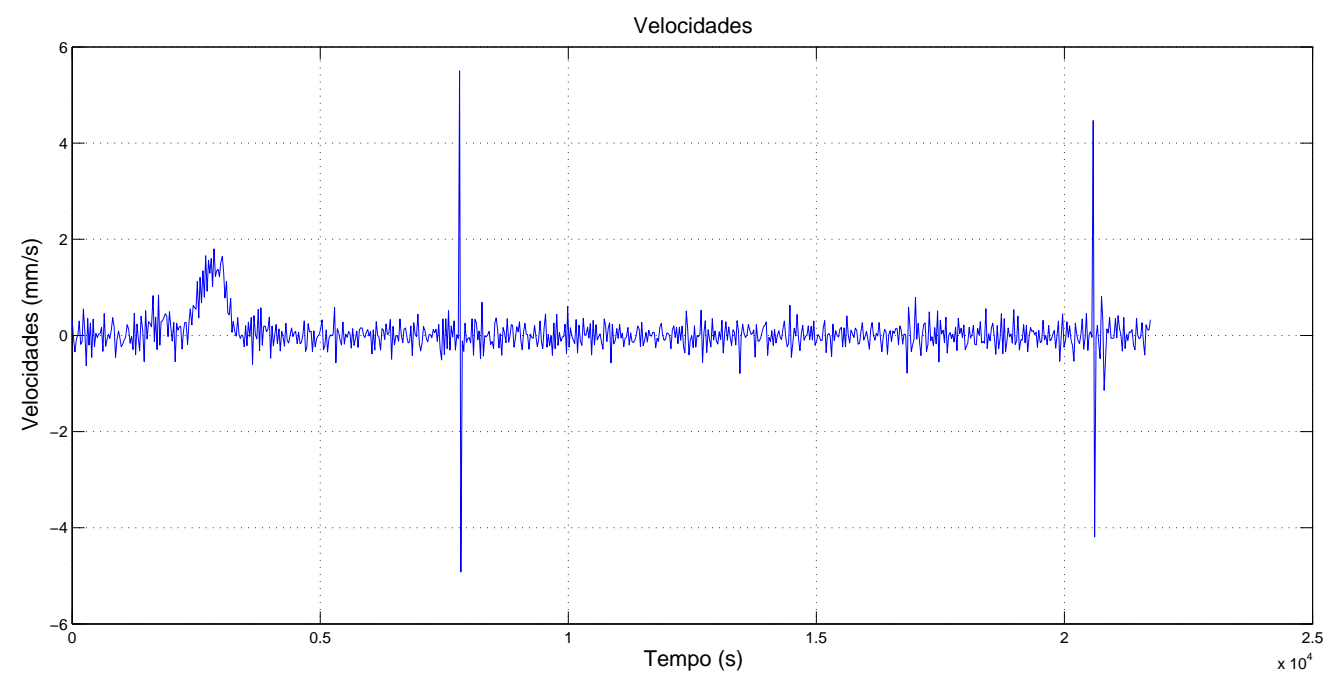

Figura 36 - Gráfico da velocidade pelo tempo.

Os dados dos plots são convertidos por uma rotina programada no PlotViewer em dois arquivos tipo texto. Um deles cria um arquivo com sufixo "EP" e o outro com sufixo "EC". O segundo contém valores de distância e amplitude de vários pontos dentro de cada frame. São dados crus, ou seja, são relatados da forma como o radar os recebe e servem de base para formar os dados do arquivo com sufixo EP que são trabalhados pelo radar de acordo com as configurações inseridas e revelam os valores eleitos da distância e amplitude para cada frame.

As configurações realizadas no Matlab com os dados dos arquivos EP e EC do segundo cenário foram realizadas de três formas diferentes: A primeira delas leva em conta a aplicação dos dados diretos de distância e amplitude do sinal do arquivo EP mais o 
tempo. Ou seja, a RNA foi treinada com essas três entradas, com um número total de 776 padrões de entradas sendo 699 usados para o treinamento e 77 para os testes. Quanto ao treinamento no toolbox do Matlab, as redes executaram o treinamento com 10, 20 e 50 neurônios na camada escondida.

\subsection{Terceiro cenário}

Os dados dessa indústria no Japão foram enviados pela empresa Rosemount da Suécia onde se localiza a fábrica de radares. Poucas informações estão disponíveis sobre essa aplicação. Basicamente, tem-se os gráficos do Radar Master, uma foto do radar instalado e uma informação de que o sinal do eco tem apresentado muitas quedas de amplitude do sinal do eco. A Figura 37 ilustra a instalação do radar para esse cenário.

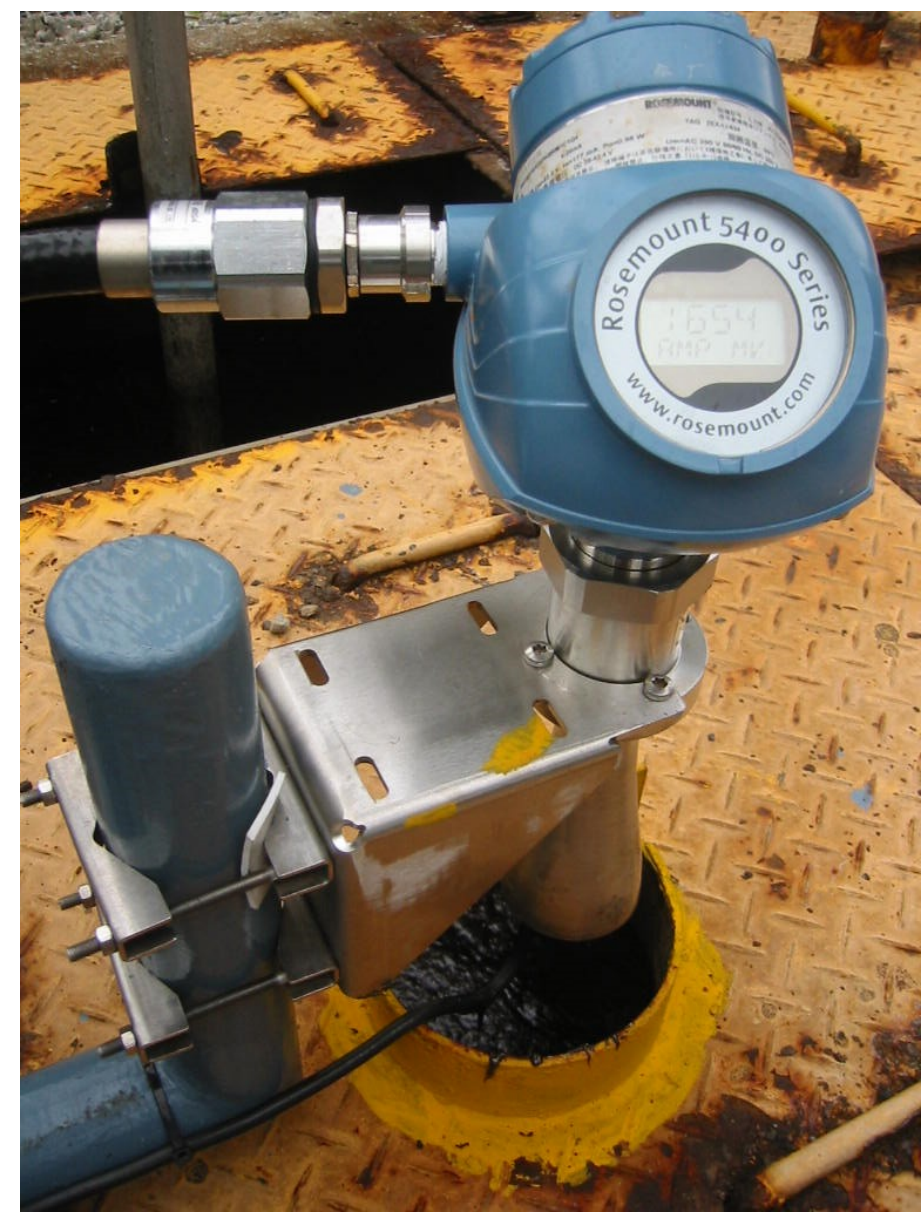

Figura 37 - Foto da instalação do radar no topo do tanque.

A classificação desse problema específico é relativamente fácil. É necessário apenas fazer um filtro de limite inferior da amplitude para se encontrar os pontos em que esse 
problema ocorre. Para essa aplicação, um filtro na amplitude para valores abaixo do limite de $200 \mathrm{mV}$ produziram um número de 1960 problemas ao qual se atribuiu o rótulo de "problema 2". Outro problema importante e mais complexo para se estabelecer um tipo de filtro nos dados que foi observado nesse e em outros gráficos, está relacionado à alta variação na amplitude que pode acontecer devido à uma severa agitação do fluido, ou pode ser que o feixe de micro-ondas esteja numa área próxima à esguichos ou de uma tubulação de entrada ou saída de fluido. Uma forma de se medir essa flutuação na amplitude é utilizar a ferramenta estatística do desvio padrão. Para ter um valor mais significativo dessa variação em relação à amplitude pode se levar em conta o valor da média. Dessa forma, o valor do desvio padrão dividido pela média é um bom indicador da magnitude da variação da amplitude.

Além disso, quando há uma alteração da distância no tempo (velocidade) é necessário que se atenue em um certo grau a classificação do problema porque é comum que no deslocamento do nível a superfície do fluido se torne mais agitada forçando uma variação da amplitude do sinal. A partir dessas considerações foi possível se escrever a Equação 21 empírica para a determinação desse problema na medição de nível nessa aplicação.

$$
\alpha \times \frac{\sigma(\text { amplitude })}{\mu(\text { amplitude })}-\beta \times(\text { velocidade }) \geq \gamma
$$

Os valores de $\alpha$ e $\beta$ foram escolhidos os menores possíveis, mas que tivessem alguma significância no resultado. Alterando-se o valor de $\beta$, por exemplo, de um ou dois décimos, é possível verificar a mudança no resultado de algumas dezenas de valores classificados em comparação com a utilização desse coeficiente como um valor nulo. A equação empírica ficou como mostrado na Equação 22 depois de vários testes para a escolha dos coeficientes.

$$
16,2 \times \frac{\sigma(\text { amplitude })}{\mu(\text { amplitude })}-0,3 \times(\text { velocidade }) \geq 1,1
$$

O valor $\gamma$ de 1,1 foi utilizado de forma a se ter um número de 1513 para se estabelecer como problemas classificados como "problema 1", que é um número correspondente a 6,57 $\%$ num universo de 23031 valores. Durante o desenvolvimento da programação das RNAs foi possível verificar que esse número de 1513 é suficiente para o treinamento e teste da rede.

A Figura 38 indica a distribuição temporal do resultado da Equação 22 relativa ao "problema 1" e o limite de amplitude relativo ao "problema 2" aplicados ao conjunto de dados da usina.

Na Figura 39 é ilustrado o gráfico da distância do sinal. O valor inicial de 1,07 m sobe rapidamente para 1,24 m em $2136 \mathrm{~s}$, apresenta uma queda para 1,08 m em 2937 $\mathrm{s}$, sobe para 1,45 m em $7475 \mathrm{~s}$, desce para 1,38 em $8052 \mathrm{~s}$, apresenta mais uma subida e uma descida com valores próximos aos imediatamente anteriores e cai para 0,66 m em 13010 s. A partir de 19200 s com o valor de 1,11 m há quase que uma repetição 


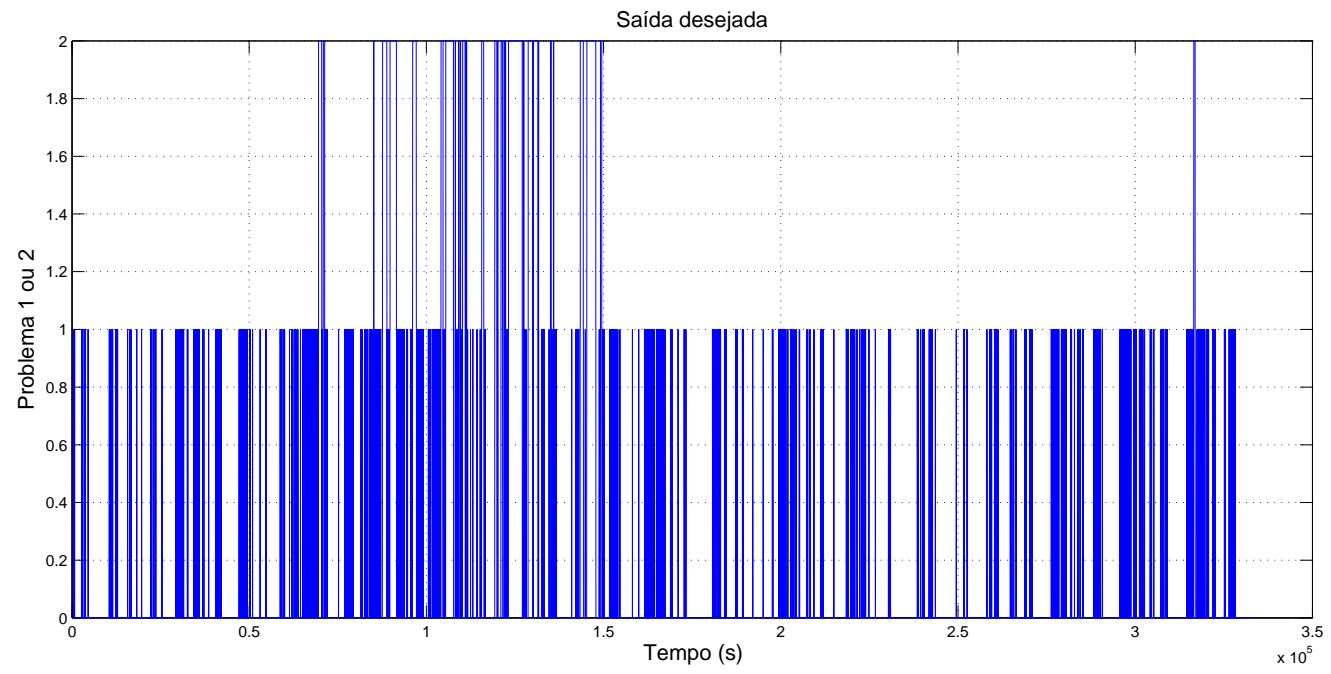

Figura 38 - Gráfico dos problemas para treinamento da RNA.

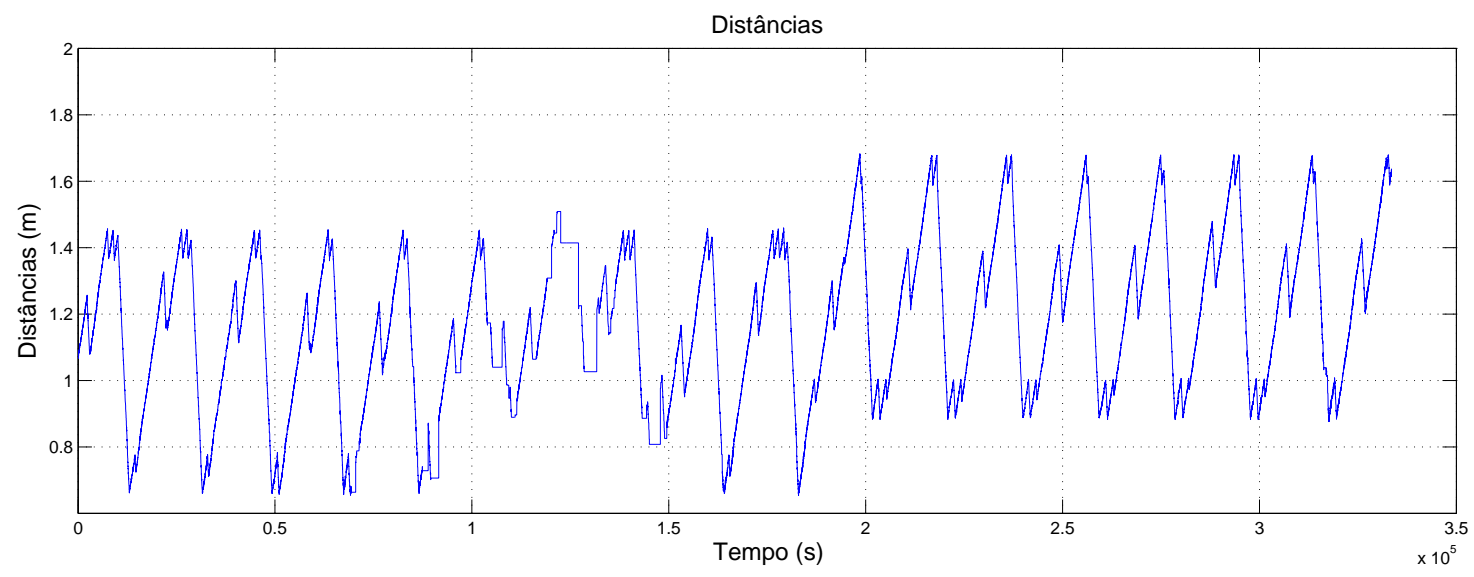

Figura 39 - Gráfico da distância pelo tempo.

do comportamento inicial da curva até esse ponto (19200 s) no tempo que se repete por mais cinco ciclos. O que seria o equivalente aos sexto e sétimo ciclos apresentam valores próximos aos anteriores, mas não atingem os valores mínimos da distância como os anteriores. Os ciclos oito e nove voltam a apresentar uma forma similar aos do início do gráfico. Após o tempo de 192600 s, um comportamento parecido da forma de onda volta a ocorrer por quase oito ciclos completos, embora estejam mais elevados que os anteriores oscilando entre máximos próximos de 1,68 m e mínimos de 0,88 m. O gráfico finaliza em 1,636 no tempo de $333600 \mathrm{~s}$.

Na Figura 40 é mostrado o gráfico da amplitude do sinal que apresenta um comportamento com um alto grau de variação. O valor inicial de $8692 \mathrm{mV}$ apresenta uma queda para o valor de $2149 \mathrm{mV}$ em $2923 \mathrm{~s}$, atinge um pico de $9735 \mathrm{mV}$ em $6829 \mathrm{~s}$, cai para 1578 mV em 12530 s, sobe para 8237 em 17480 s, continua com uma alta oscilação de valores 


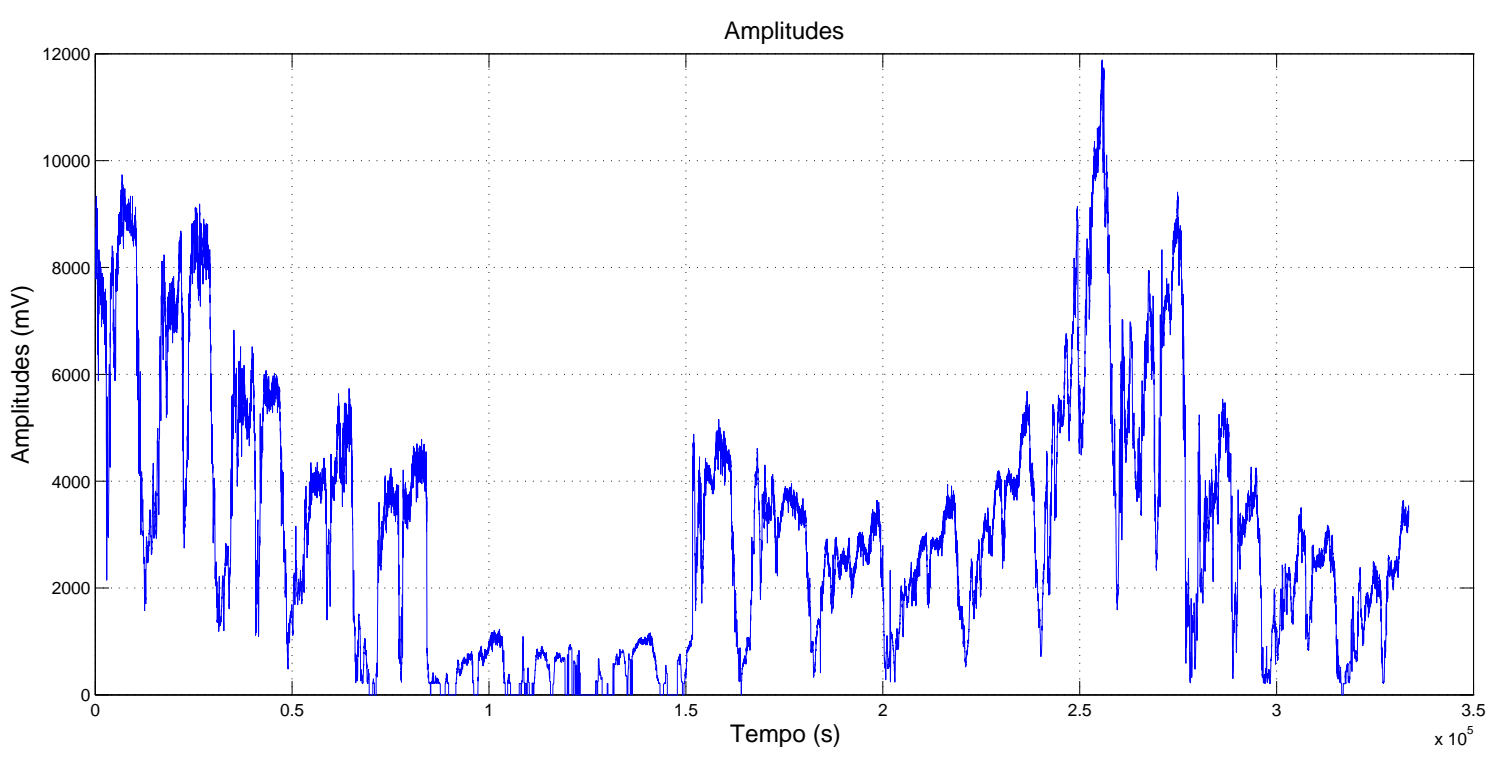

Figura 40 - Gráfico da amplitude pelo tempo.

e entre 84620 e 150000 s apresenta oscilações com amplitudes menores entre 0 e 1200 $\mathrm{mV}$. Os próximos valores apresentam oscilações de amplitude entre zero e $5606 \mathrm{mV}$ até o tempo de 245400 s. Na continuação há o valor de 11890 mV em 255700s. A amplitude cai para $1591 \mathrm{mV}$ em $259500 \mathrm{~s}$, sobre para $9302 \mathrm{mV}$ em $274900 \mathrm{~s}$, atinge $5536 \mathrm{mV}$ em 286300 s, 232,9 mV em 297700 s, $3127 \mathrm{mV}$ em $313200 \mathrm{~s}$ terminando em $333600 \mathrm{~s}$ com o valor de $3444 \mathrm{mV}$.

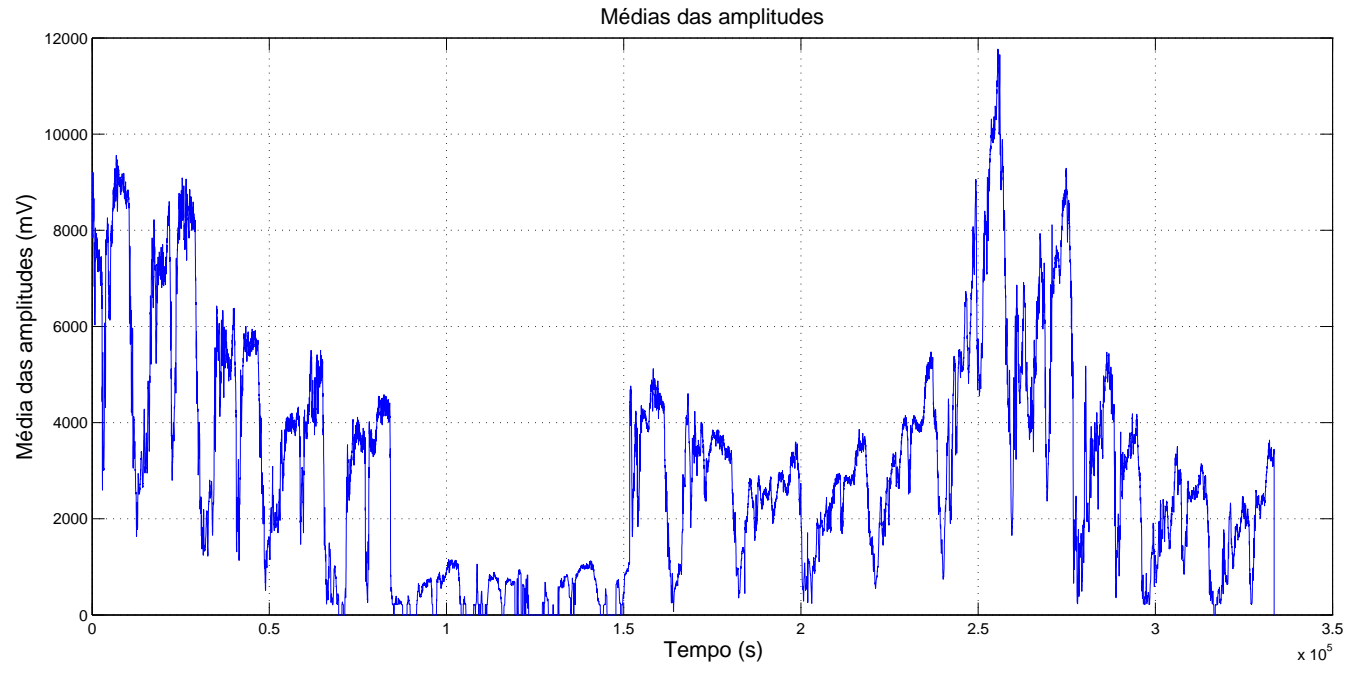

Figura 41 - Gráfico da média das amplitudes pelo tempo.

A ilustração da Figura 41 relativa à média das amplitudes tomadas com janelamento de 2 em 2 elementos é, como pode-se esperar, muito semelhante ao gráfico das amplitudes 
pelo tempo.

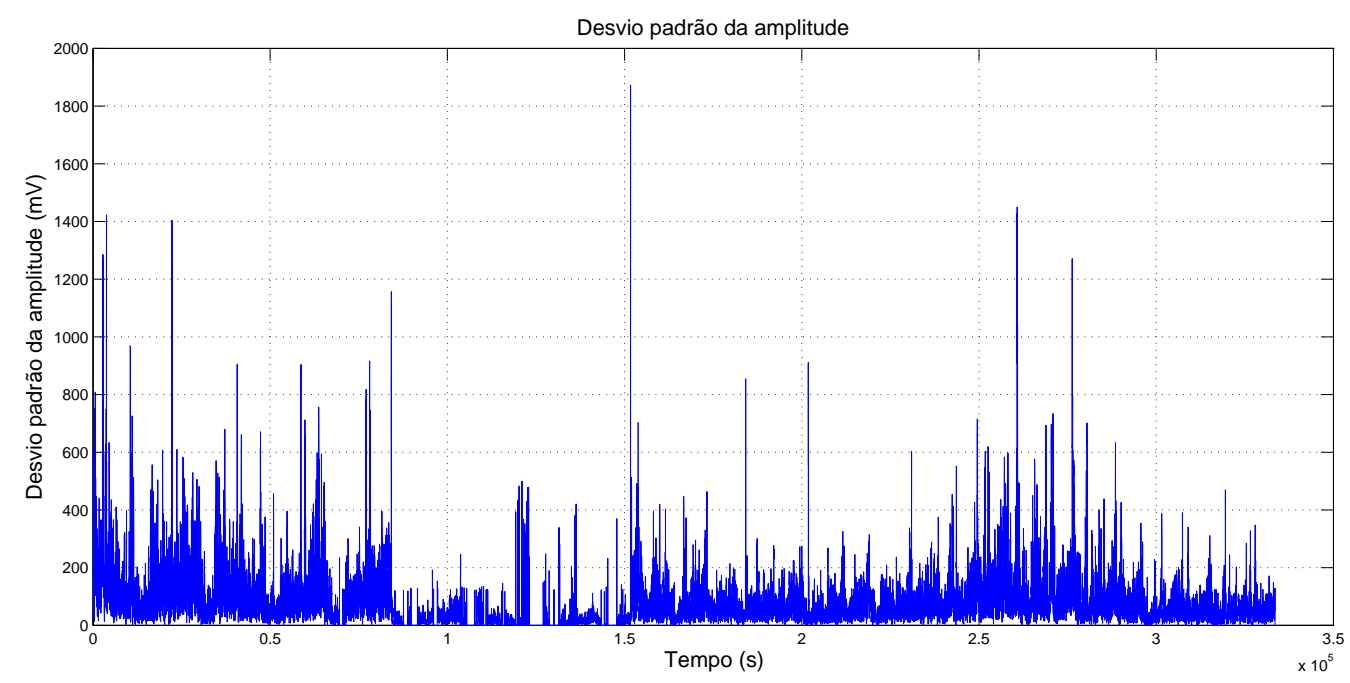

Figura 42 - Gráfico do desvio padrão pelo tempo.

Na Figura 42 é mostrado o gráfico do desvio padrão das amplitudes pelo tempo. Os picos, que chegam a $1873 \mathrm{mV}$, traduzem uma alta oscilação nos valores da amplitude do sinal do eco recebido pelo radar.

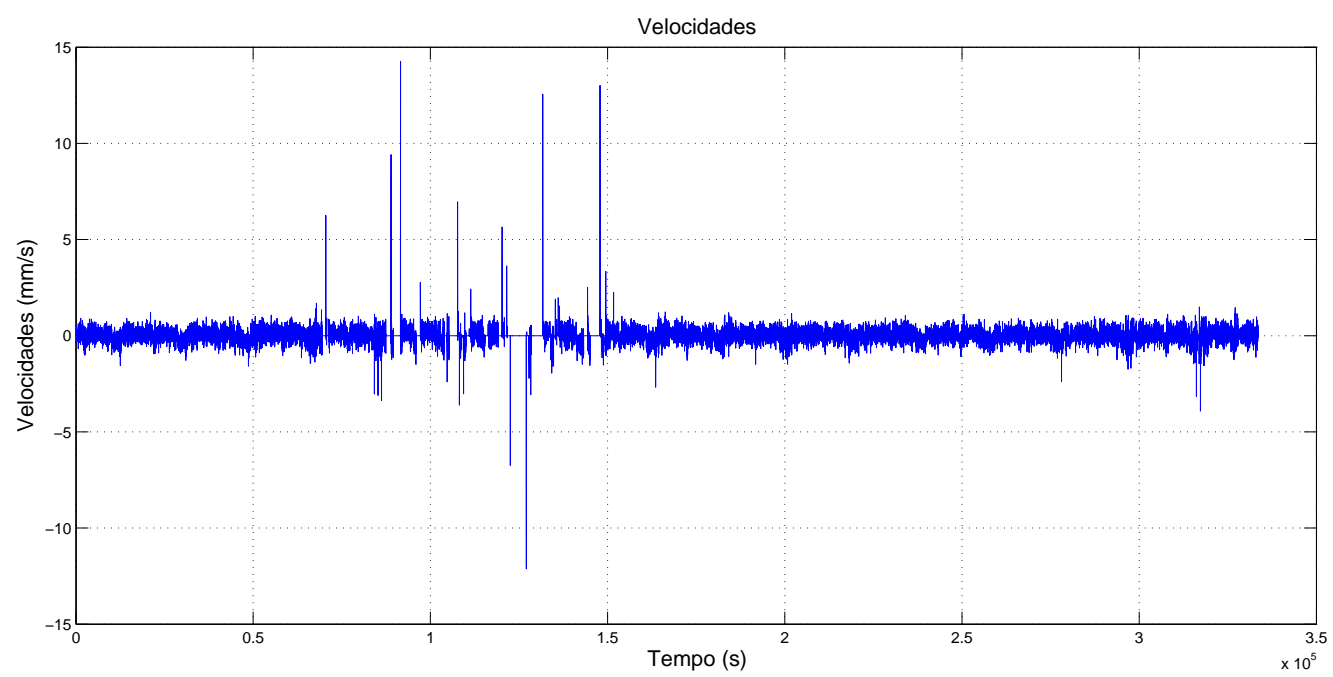

Figura 43 - Gráfico da velocidade pelo tempo.

Na Figura 43 é ilustrado o gráfico da velocidade da distância pelo tempo. A maioria das variações da distância no tempo estão concentradas entre os valores de $-1,4$ a $+1,4$ $\mathrm{mm} / \mathrm{s}$. Alguns valores que extrapolam esses limites podem ser ressaltados como o valor de $6,25 \mathrm{~mm} / \mathrm{s}$ no tempo de $70490 \mathrm{~s}$, o de $-3,36 \mathrm{~mm} / \mathrm{s}$ em $86200 \mathrm{~s}, 9,41 \mathrm{~mm} / \mathrm{s}$ em 88890 s, $14,25 \mathrm{~mm} / \mathrm{s}$ em $91560 \mathrm{~s}, 6,96 \mathrm{~mm} / \mathrm{s}$ em $10770 \mathrm{~s},-3,60$ em $108200 \mathrm{~s},-6,74 \mathrm{em} 122500$ 
s, $-12,13 \mathrm{~mm} / \mathrm{s}$ em $127100 \mathrm{~s}, 12,56 \mathrm{~mm} / \mathrm{s}$ em $131700 \mathrm{~s}, 13,01 \mathrm{~mm} / \mathrm{s}$ em $147900 \mathrm{~s}$ e $-3,92$ $\mathrm{mm} / \mathrm{s}$ em $317300 \mathrm{~s}$.

\subsection{Quarto cenário}

O último cenário vem de uma aplicação na área de óleo e gás. Esses dados foram enviados também pela fábrica de radares da Suécia e a linha do threshold que é a linha hachurada azul que está acima de quase toda a curva de eco, exceto pela área que mostra a medição do nível indicada pela seta na posição superior da tela, na Figura 44. Pressupõese que há muitos obstáculos no espaço entre a antena do radar e a superfície do fluido pela quantidade de ecos falsos nessa área do gráfico. Observando-se as variações da amplitude e da distância, os mesmos problemas indicados para a aplicação da fábrica no terceiro cenário foram identificados.

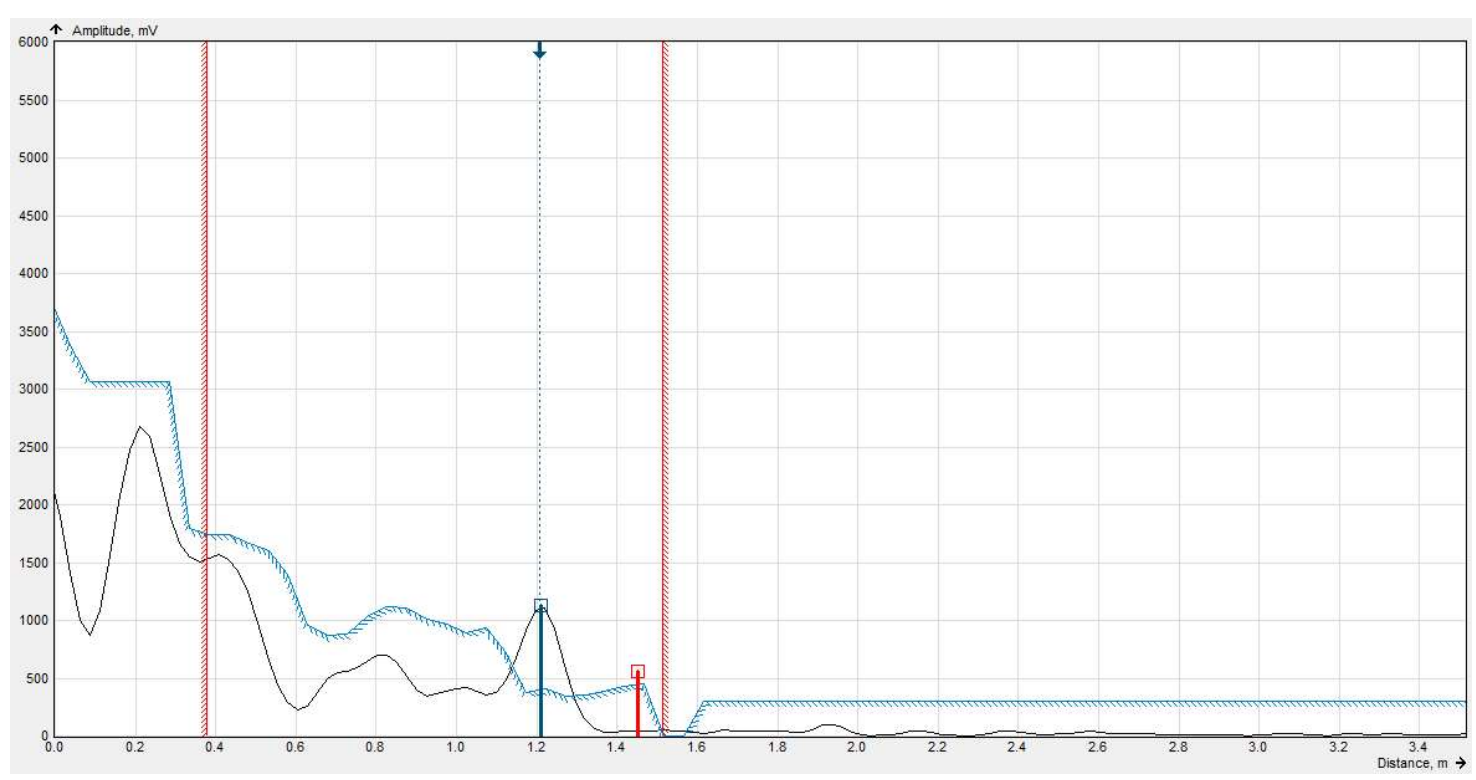

Figura 44 - Gráfico da amplitude pela distância.

O número total de frames utilizados foi de 85368 sendo que 76769 foram utilizados para treinamento e 8599 para testes.

Analogamente o que foi feito no estudo anterior da usina do terceiro cenário, empiricamente foram escolhidos os coeficientes indicados na Equação 23 a seguir:

$$
11,2 \times \frac{\sigma(\text { amplitude })}{\mu(\text { amplitude })}-0,4 \times(\text { velocidade }) \geq 2,15
$$

O número de "problemas 1" determinados pela Equação 23 foi de 14686 pontos num universo de 85369 que representa 17,20 \% do total. Quanto ao "problema 2" representado pela amplitude baixa, considerando-se o limite de $90 \mathrm{mV}$ e valores inferiores, 11123 pontos foram identificados dentro dos 85369, o que corresponde a 13,03\% dos dados. 


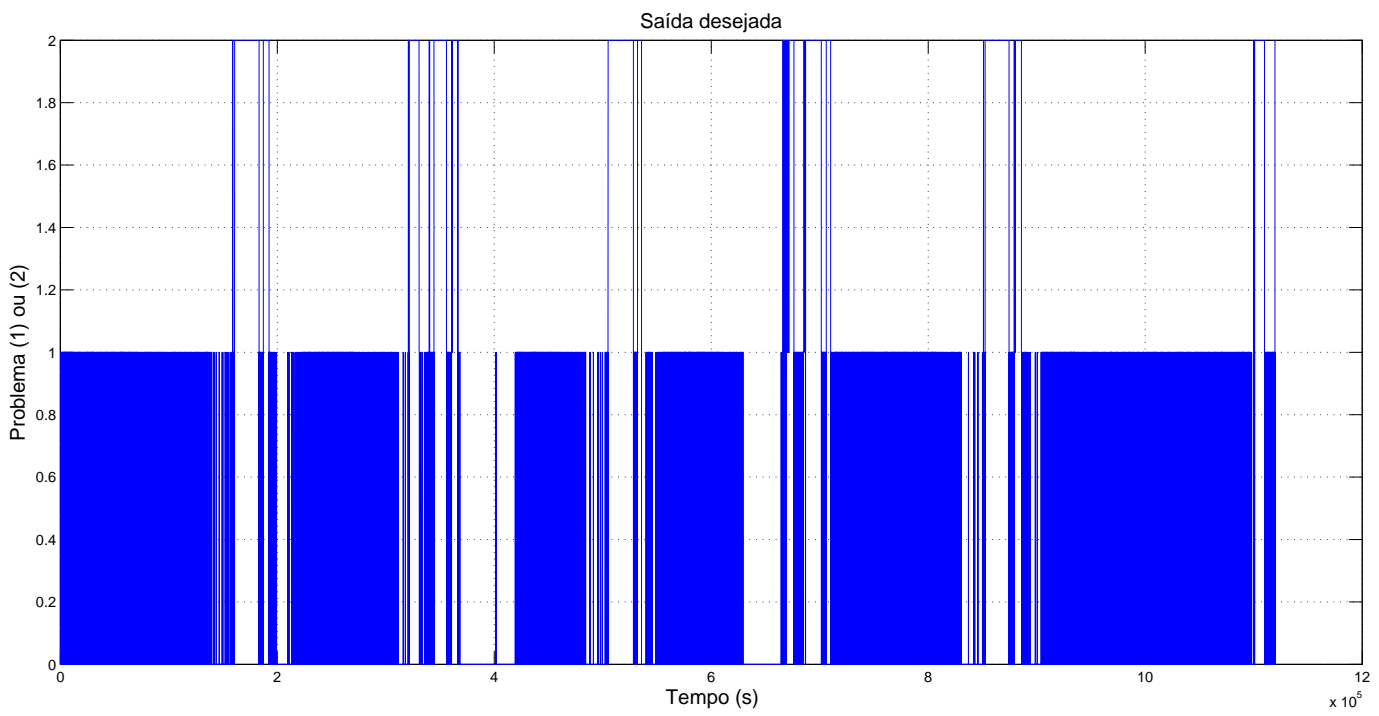

Figura 45 - Gráfico dos problemas para treinamento da RNA.

Na Figura 45 é ilustrado o gráfico dos problemas para o treinamento da RNA e do SVM conforme a Equação 23 relativo ao "problema 1" e o valor do limite da amplitude que gerou os pontos do "problema 2 ".

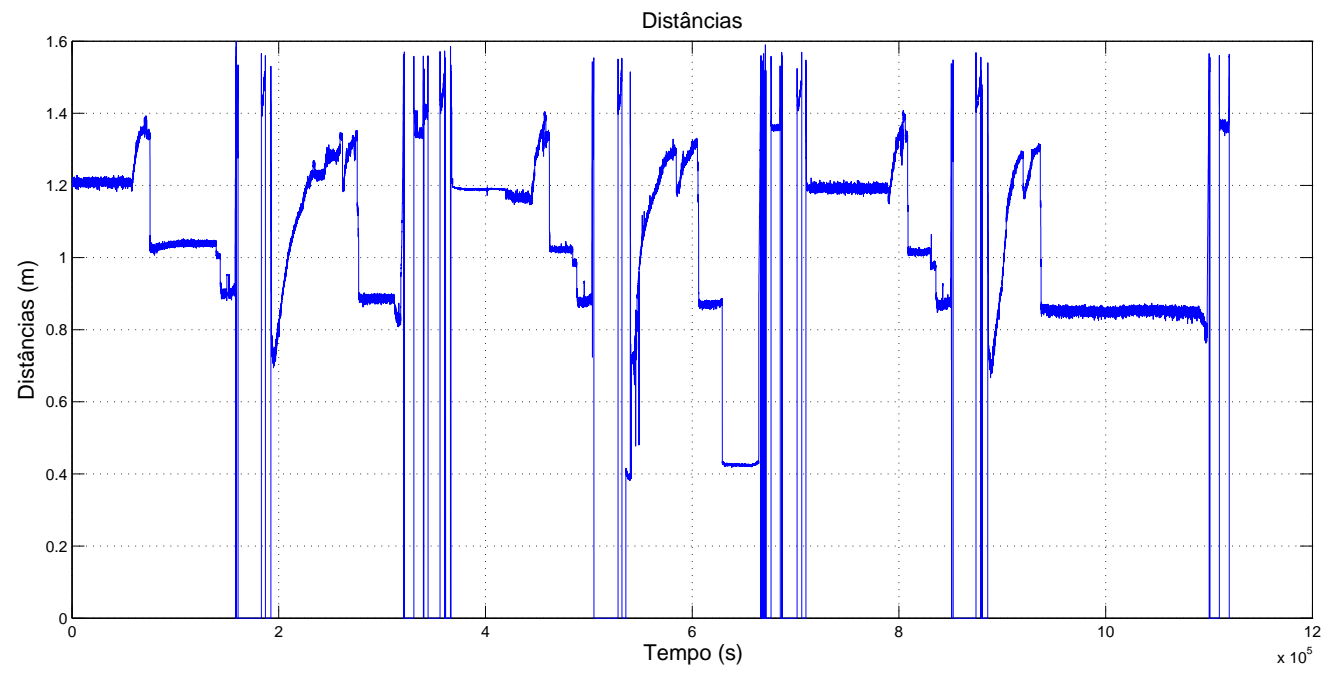

Figura 46 - Gráfico da distância pelo tempo.

A Figura 46 indica o comportamento temporal da distância cujo valor inicial de 1,21 m sofre pequenas alterações até o tempo de $57780 \mathrm{~s}$. A partir desse momento, a distância se eleva até $1382 \mathrm{~m}$ em $72280 \mathrm{~s}$, cai para 1,02 m em $75610 \mathrm{~s}$ ficando próximo à esse patamar até o 139500 s. Depois sofre uma queda para o valor de 0,89 m em 145300 s ficando próximo à esse limite até o tempo de $157700 \mathrm{~s}$. A distância vai para zero em $158800 \mathrm{~s}$, sobe 1,60 entre 158000 e 159400 s e volta a cair para zero em 160648 s permanecendo 
nesse valor até 183193 s. A distância começa a aumentar atingindo os 1,56 m em 183206 s. O gráfico apresenta mais duas repetições de valores altos como 1,56 m e baixos como zero chegando a $0,70 \mathrm{~m}$ em 1,95100 s. No tempo de $272100 \mathrm{~s}$ atinge o valor de 1,34 m caindo para $0,88 \mathrm{~m}$ em $277500 \mathrm{~s}$ e permanece aproximadamente nesse valor até 31200 s. Após esse instante, começa a cair até $0,82 \mathrm{~m}$ em $316900 \mathrm{~s}$. Na sequência apresenta um pico de 1,56 m em $320700 \mathrm{~s}$, vai para zero em $321000 \mathrm{~s}$. A distância apresenta mais algumas alterações entre o valor próximo a 1,57 m e zero. Em 368900 s, o valor da distância está em 1,19 m e mantém próximo à esse valor até o tempo de 417100. Existe uma similaridade do comprotamento temporal da distância considerada do tempo zero até 417100 s com outros dois ciclos consecutivos até o tempo final de 1120000 s. Uma excessão é que entre 937600 e 109500 s, a amplitude permanece entre 0,82 e 0,87. Esse trecho de valor é visivelmente mais longo no gráfico que os outros ciclos anteriores.

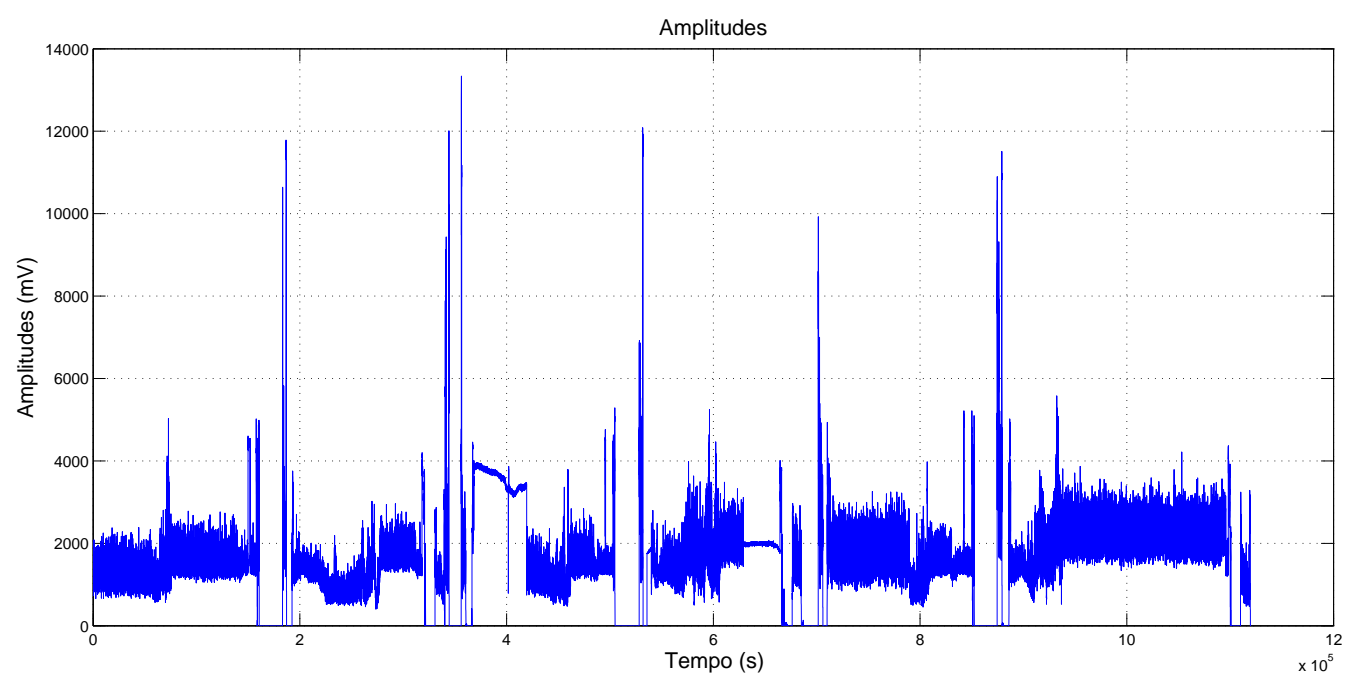

Figura 47 - Gráfico da amplitude pelo tempo.

A Figura 47 ilustra a variação da amplitude no tempo iniciando com o valor de 1131 $\mathrm{mV}$ e varia numa faixa de 589 a $2300 \mathrm{mV}$ até o tempo de $72890 \mathrm{~s}$ quando chega a um pico de $5025 \mathrm{mV}$. Depois volta a excursionar entre 1066 e $2737 \mathrm{mV}$ até o tempo de 149200 s. Após esse tempo, o gráfico apresenta alguns picos de próximos a $5016 \mathrm{mV}$, permanece em zero entre 16060 e $18320 \mathrm{~s}$, volta a subir atingindo o valor de $11750 \mathrm{mV}$ em $186700 \mathrm{~s}$ Oscila entre 522 e $2950 \mathrm{mV}$ até $321300 \mathrm{~s}$. Fica em zero entre $321600 \mathrm{~s} 330700 \mathrm{~s}$. Apresenta um pico de $13340 \mathrm{mV}$ em $356200 \mathrm{~s}$, apresenta variações entre 476 e $4000 \mathrm{mV}$ até $504900 \mathrm{~s}$ onde fica em zero até $528300 \mathrm{~s}$. Volta a subir e atinge um pico de $1193 \mathrm{mV}$ em $531900 \mathrm{~s}$. Apresenta valores que variam de 575 até $4000 \mathrm{mV}$ aproximadamente até $668700 \mathrm{~s}$ quando volta a ficar em zero até $67630 \mathrm{~s}$ com excessão do pico de $5246 \mathrm{mV}$ em $596300 \mathrm{~s}$. Apresenta um pico de 9902 mV em 701700 s, mantém uma faixa de variação entre 520 e 3200 mV, depois volta a permanecer em zero entre 852500 e 87450 s. Na sequência sobe para 11480 
mV em 879100 s permanece em zero entre 879300 e 886000 s. Após volta a excursionar entre valores de 568 a $4300 \mathrm{mV}$ até o tempo de 1100000 . Entre esse último e $1110000 \mathrm{~s}$ a amplitude permanece em zero. O valor final do tempo para o gráfico é $1120000 \mathrm{~s}$.

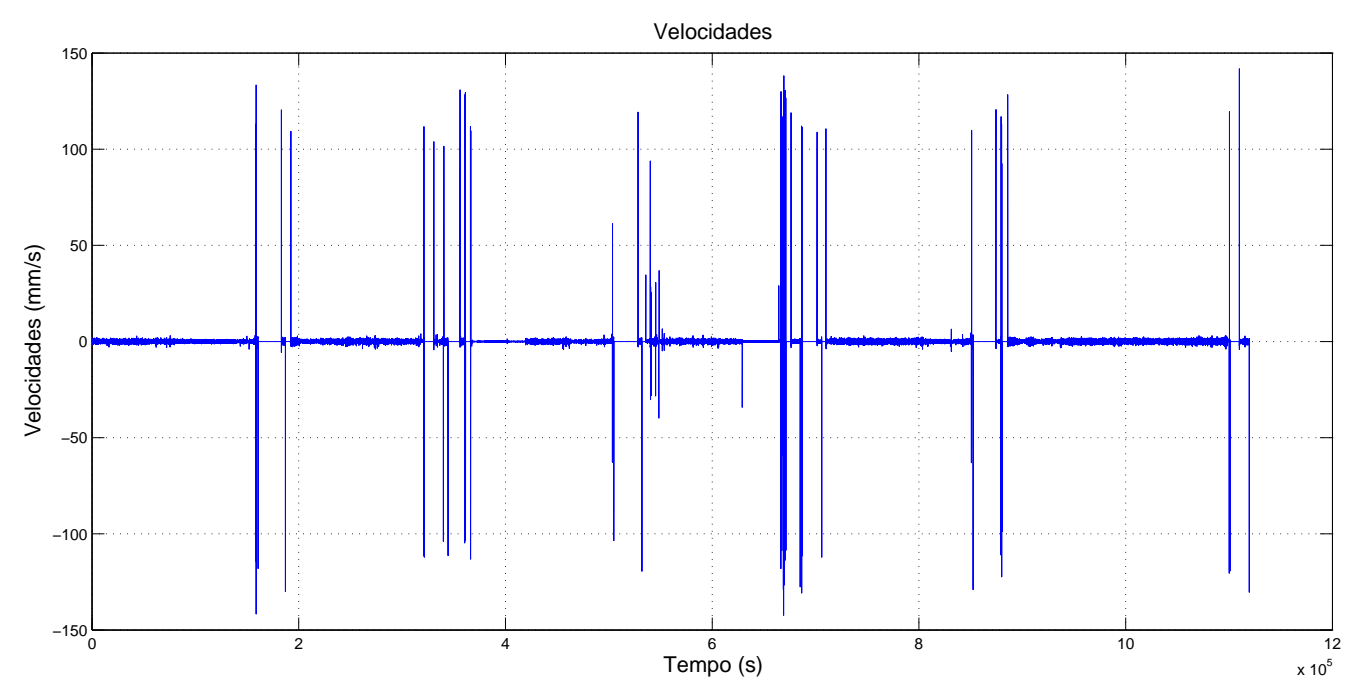

Figura 48 - Gráfico da velocidade pelo tempo.

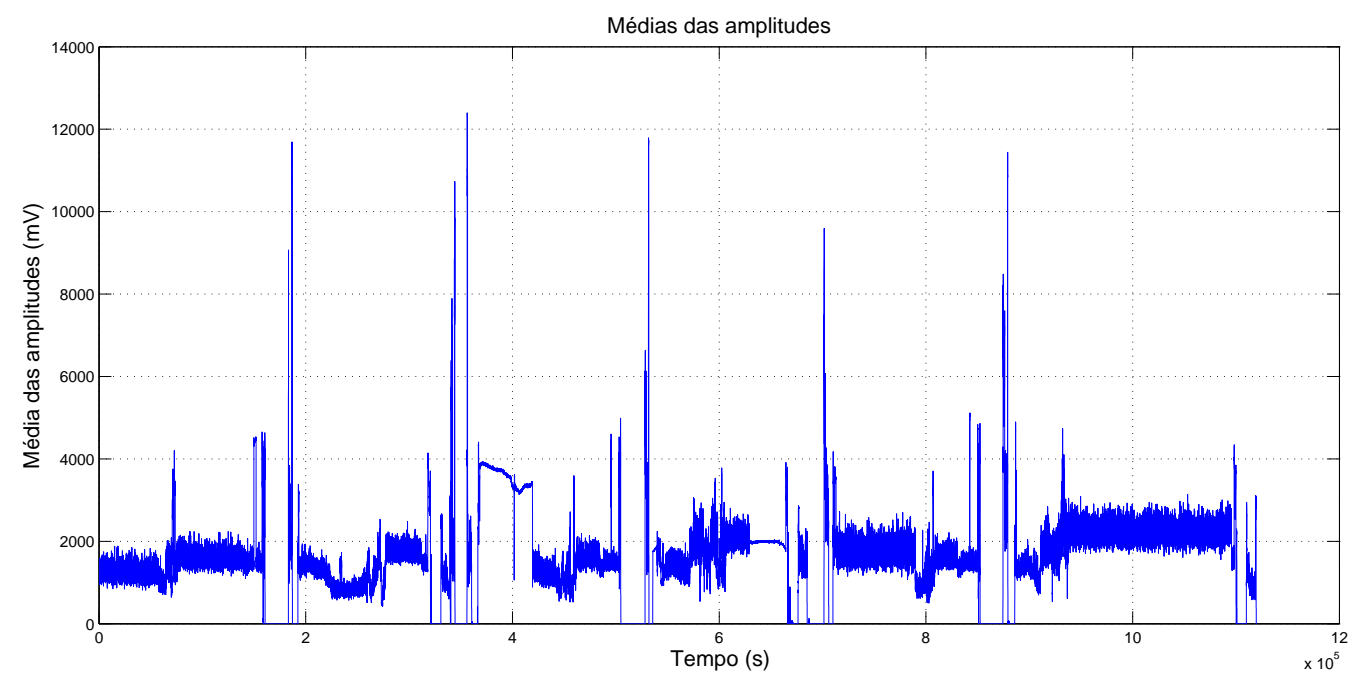

Figura 49 - Gráfico da média das amplitudes pelo tempo.

A velocidade versus o tempo aparece na Figura 48. Ao se comparar o gráfico da velocidade com o da distância é possível se observar que as maiores taxas de variação da distância estão representadas nos picos e vales do gráfico da velocidade. Os valores máximos e mínimos são de $141,8 \mathrm{~mm} / \mathrm{s}$ que ocorre mais ao final do gráfico, mais precisamente em $1110000 \mathrm{~s}$ e de $-141,6 \mathrm{~mm} / \mathrm{s}$ que ocorre em $158700 \mathrm{~s}$ mais no início do gráfico. A maioria dos dados de velocidade se concentram entre $-4,60$ e $5,50 \mathrm{~mm} / \mathrm{s}$. 
Os valores da média das amplitudes podem ser observados na Figura 49. Para esse gráfico, a janela dos dados da amplitude foram tomados de 2 em 2 elementos. Como esperado, esse gráfico é muito próximo do gráfico da amplitude.

Além da média da amplitude, na Figura 50 pode se observar outro tratamento estatístico dos dados do processo. O desvio padrão das amplitudes que apresenta a maioria dos valores abaixo de $1000 \mathrm{mV}$, mas também são observáveis alguns picos como o de 4518 mV em 183300 s, 4425 mV em 356600 s 4395 mV em 5316 s e 4450 mV em 874600 s. O janelamento dos dados para o cálculo do desvio padrão foi de 2 elementos como no caso do gráfico da média.

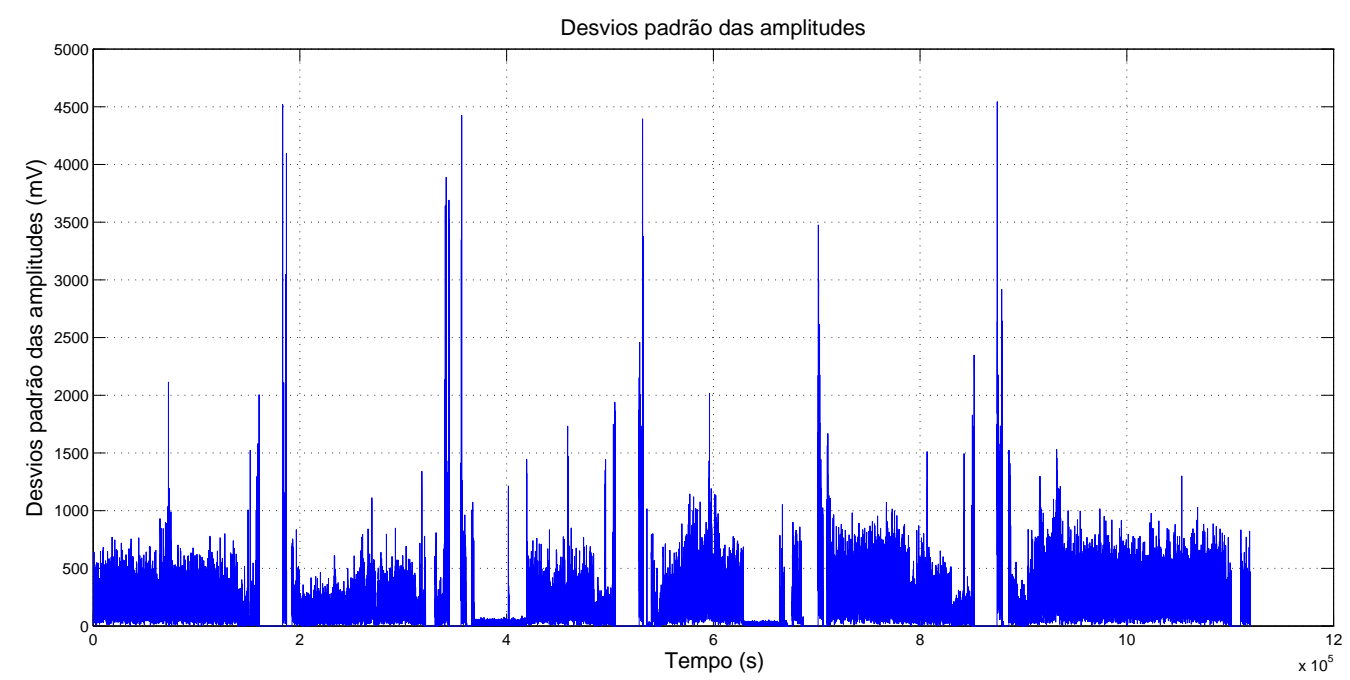

Figura 50 - Gráfico do desvio padrão das amplitudes pelo tempo. 


\section{Resultados e discussões}

Esse capítulo trata dos resultados obtidos pela análise estatistica e treinamento da RNA e do SVM com base nos dados adquiridos do radar explanados no capítulo anterior. As redes trabalhadas foram do tipo multiperceptron Silva, Spatti e Flauzino (2010) e HAYKIN (2008). Os resultados do SVM foram computados pelo software Weka.

\subsection{Configurações utilizadas do SVM e RNA}

O support vector machine foi utilizado com a biblioteca LIBSVM dentro do frame Weka WITTEN (2014). Esse frame permite a chamada de arquivos estruturados em formato arff. A partir do Matlab, os mesmos arquivos de treinamento e de teste para cada uma das aplicações da RNA foram exportados em arquivos no formato texto (.txt) e depois disso foram trabalhados no Notepad ++ para acrescentar os cabeçalhos e converter os aquivos para arff. Na interface do frame Weka, os arquivos foram importados e foi escolhido a classificação por funções chamando a biblioteca do LIBSVM. Os kernels disponíveis como o RBF (radial basis functio), linear, sigmodal e polinomial foram utilizados.

Para todos os kernels, o valor de eps, que é a tolerância do critério de término, foi utilizado de 0,001. O valor de loss $(\epsilon)$ foi de 0,1. Existe uma nota no Weka sobre o valor de Gamma $(\gamma)$ utilizado por padrão como valor nulo, que informa que nesse caso, 1/(índice máximo) é utilizado para a configuração interna do frame. Para o kernel polinomial, o coef0 usado foi zero e grau do polinômio foi 3. Alguns graus diferentes como 4 e 5 foram testados, mas não apresentaram resultados superiores ao grau 3, motivo pelo qual manteve-se esse valor.

A Equação 24 ilustra a fórmula utilizada para o kernel polinomial mostrada na interface do frame.

$$
K(u, v)=\left(\gamma * u^{\prime} * v+\text { coef } 0\right)^{\text {degree }}
$$

A Equação 25 ilustra a fórmula utilizada para o kernel RBF. 


$$
K(u, v)=e^{\left(-\gamma *|u-v|^{2}\right)}
$$

A Equação 26 mostra a fórmula para o kernel sigmoidal.

$$
K(u, v)=\tanh \left(\gamma * u^{\prime} * v+\operatorname{coe} f 0\right)
$$

Na Equação 27 é ilustrada a fórmula para o kernel linear.

$$
K(u, v)=\left(u^{\prime} * v\right)
$$

Para o desenvolvimentos das programações das RNAs no Matlab, as saídas desejadas foram utilizadas como valores inteiros. Para o frame Weka, esses valores mais conhecidos por "labels" na terminologia do SVM foram transformados para valores tipo texto.

Na Tabela 8 estão indicadas as correlações entre as saída da RNA e do SVM:

Tabela 8 - Labels de correspondência entre RNA e SVM.

\begin{tabular}{ccl}
\hline & & \multicolumn{1}{c}{ Primeiro cenário } \\
\hline RNA & SVM & Explicação \\
\hline 1 & ENCHENDO & Fase de enchimento do tanque \\
2 & CALMA & Fase de molho com superfície calma \\
3 & AGITACAO & Fase do agitador ligado com superfície turbulenta \\
4 & ESPUMA & Adição de espuma na superfície do fluido \\
5 & MUITAESPANT & Adição de espuma na antena \\
6 & MENOSESPANT & Redução de espuma na antena \\
7 & ESVAZIANDO & Fase de esvaziamento do tanque \\
\hline & & Segundo cenário \\
\hline RNA & SVM & Explicação \\
\hline 1 & SEMPROBL & Sem problemas de medição \\
2 & VAPeAGIT & Vapor e agitação do fluido \\
\hline & & Terceiro cenário \\
\hline RNA & SVM & Explicação \\
\hline 1 & SEMPROBL & Sem problemas de medição \\
2 & HIVARAMPL & Alta variação na amplitude do eco \\
3 & LOAMPL & Baixa amplitude do eco \\
\hline & & Quarto cenário \\
\hline RNA & SVM & Explicação \\
\hline 1 & SEMPROBL & Sem problemas de medição \\
2 & HIVARAMPL & Alta variação na amplitude do eco \\
3 & LOAMPL & Baixa amplitude do eco \\
\hline
\end{tabular}

O próximo capítulo irá mostrar os resultados obtidos em forma de tabelas indicativas dos acertos dos treinamentos das RNAs e das classificações dos SVMs. 


\subsubsection{Resultados do primeiro cenário}

A Tabela 9 mostra os resultados referentes ao treinamento da RNA com 5, 10 e 20 neurônios com 3 entradas: distância, amplitude e tempo advindas do arquivo EP, ou seja, os valores de distância e amplitude eleitos pelo radar para cada frame.

Tabela 9 - Resultados do treinamento apenas com os dados do arquivo EP.

\begin{tabular}{rrrc}
\hline & \multicolumn{1}{c}{ 5n } & \multicolumn{1}{c}{$10 \mathrm{n}$} & $20 \mathrm{n}$ \\
\hline Teste1 & $100,00 \%$ & $100,00 \%$ & $100,00 \%$ \\
Teste2 & $100,00 \%$ & $100,00 \%$ & $100,00 \%$ \\
Teste3 & $100,00 \%$ & $100,00 \%$ & $100,00 \%$ \\
Teste4 & $100,00 \%$ & $94,44 \%$ & $100,00 \%$ \\
Teste5 & $94,44 \%$ & $100,00 \%$ & $100,00 \%$ \\
\hline
\end{tabular}

A Tabela 10 ilustra os resultados obtidos a partir da utilização de 7 entradas: $\mathrm{D}(\mathrm{t}$ 2), $\mathrm{D}(\mathrm{t}-1), \mathrm{D}(\mathrm{t}), \mathrm{A}(\mathrm{t}-2), \mathrm{A}(\mathrm{t}-1), \mathrm{A}(\mathrm{t})$ e o tempo onde o valor de $\mathrm{D}(\mathrm{t}-2)$ e $\mathrm{A}(\mathrm{t}-2)$ são os valores de distância e amplitude de 2 frames anteriores, $\mathrm{D}(\mathrm{t}-1)$ e $\mathrm{A}(\mathrm{t}-1)$ são os valores de distância e amplitude de 1 frame anterior e $\mathrm{D}(\mathrm{t})$ e $\mathrm{A}(\mathrm{t})$ são os valores de distância e amplitude atuais. Essa tentativa foi realizada para se verificar se a consideração desses valores defasados no tempo trariam alguma vantagem em relação à melhor desempenho da RNA.

\begin{tabular}{rrrr} 
Tabela & \multicolumn{4}{c}{ Resultados das entradas defasadas no t } \\
\cline { 2 - 4 } & $5 \mathrm{n}$ & $10 \mathrm{n}$ & $20 \mathrm{n}$ \\
\hline Teste1 & $77,78 \%$ & $83,33 \%$ & $83,33 \%$ \\
Teste2 & $83,33 \%$ & $88,89 \%$ & $77,78 \%$ \\
Teste3 & $83,33 \%$ & $83,33 \%$ & $88,89 \%$ \\
Teste4 & $33,33 \%$ & $72,22 \%$ & $83,33 \%$ \\
Teste5 & $88,89 \%$ & $77,78 \%$ & $77,78 \%$ \\
\hline
\end{tabular}

A Tabela 11 mostra os resultados referentes ao treinamento da RNA com 5, 10 e 20 neurônios com 29 entradas: Valores de média e de desvio-padrão para cada entrada D1, D2, D3, D4, D5, D6, D7, A1, A2, A3, A4, A5, A6, A7 que somam 28 entradas mais o valor do tempo. Para essa alternativa de treinamento das redes neurais utilizou-se os dados do arquivo EP somados aos do arquivo EC. A finalidade desse procedimento foi ter uma representatividade maior da curva de eco. Um programa feito no Matlab tomou para cada frame o valor da distância do arquivo EP e procurou o valor mais próximo deste no arquivo EC. Uma vez encontrado esse valor de distância mais próximo, três valores imediatamente inferiores e três valores imediatamente superiores de distância e seus correspondentes valores de amplitude foram tomados do arquivo EC. Dessa forma, os valores D4 e A4 são os valores da distância e amplitude provenientes do arquivo EP. As amplitudes A1 até A3 e A5 até A7 que estão associadas às distâncias D1 até D3 e D5 
até D7 são provenientes do arquivo EC. O pré-processamento utilizou o conceito da janela deslizante contendo 2, 3, 5, 7 e 9 elementos para os cálculos da média e do desvio-padrão dos dados D1 a D7 e A1 a A7. Dessa forma as entradas seguiram a estrutura de dados de entrada da rede neural: $\mu \mathrm{D} 1, \mu \mathrm{D} 2, \mu \mathrm{D} 3, \mu \mathrm{D} 4, \mu \mathrm{D} 5, \mu \mathrm{D} 6, \mu \mathrm{D} 7, \sigma \mathrm{D} 1, \sigma \mathrm{D} 2, \sigma \mathrm{D} 3, \sigma \mathrm{D} 4$, $\sigma \mathrm{D} 5, \sigma \mathrm{D} 6, \sigma \mathrm{D} 7, \mu \mathrm{A} 1, \mu \mathrm{A} 2, \mu \mathrm{A} 3, \mu \mathrm{A} 4, \mu \mathrm{A} 5, \mu \mathrm{A} 6, \mu \mathrm{A} 7, \sigma \mathrm{A} 1, \sigma \mathrm{A} 2, \sigma \mathrm{A} 3, \sigma \mathrm{A} 4, \sigma \mathrm{A} 5, \sigma \mathrm{A} 6$, $\sigma \mathrm{A} 7$, e o tempo onde $\mu$ representa o valor da média e $\sigma$ o valor do desvio-padrão.

Para o critério de parada do treinamento da RNA foi considerado o valor de 1e-6 de mse (mean squared error) ou 1000 épocas para todos os cenários.

A Tabela 11 ilustra os resultados da RNA com pré-processamento estatístico de janelas de 2 elementos.

Tabela 11 - Resultados do pré-processamento estatístico com $\mathrm{j}=2$.

\begin{tabular}{lrrr}
\hline & \multicolumn{1}{c}{$5 \mathrm{n}$} & \multicolumn{1}{c}{$10 \mathrm{n}$} & \multicolumn{1}{c}{$20 \mathrm{n}$} \\
\hline Teste1 & $100,00 \%$ & $100,00 \%$ & $100,00 \%$ \\
Teste2 & $94,44 \%$ & $94,44 \%$ & $88,89 \%$ \\
Teste3 & $88,89 \%$ & $100,00 \%$ & $94,44 \%$ \\
Teste4 & $94,44 \%$ & $88,89 \%$ & $100,00 \%$ \\
Teste5 & $100,00 \%$ & $100,00 \%$ & $94,44 \%$ \\
\hline
\end{tabular}

A Tabela 12 mostra os resultados da RNA com janelas de 3 elementos.

Tabela 12 - Resultados do pré-processamento estatístico com $\mathrm{j}=3$.

\begin{tabular}{cccc}
\hline & $5 \mathrm{n}$ & $10 \mathrm{n}$ & $20 \mathrm{n}$ \\
\hline Teste1 & $94,44 \%$ & $94,44 \%$ & $88,89 \%$ \\
Teste2 & $94,44 \%$ & $83,33 \%$ & $88,89 \%$ \\
Teste3 & $50,00 \%$ & $72,22 \%$ & $94,44 \%$ \\
Teste4 & $94,44 \%$ & $88,89 \%$ & $88,89 \%$ \\
Teste5 & $88,89 \%$ & $88,89 \%$ & $88,89 \%$ \\
\hline
\end{tabular}

A Tabela 13 mostra os resultados da RNA com janelamento de 5 elementos.

Tabela 13 - Resultados do pré-processamento estatístico com $\mathrm{j}=5$.

\begin{tabular}{lrrr}
\hline & $5 \mathrm{n}$ & $10 \mathrm{n}$ & $20 \mathrm{n}$ \\
\hline Teste1 & $33,33 \%$ & $11,11 \%$ & $5,56 \%$ \\
Teste2 & $11,11 \%$ & $5,56 \%$ & $5,56 \%$ \\
Teste3 & $11,11 \%$ & $5,56 \%$ & $16,67 \%$ \\
Teste4 & $38,89 \%$ & $5,56 \%$ & $5,56 \%$ \\
Teste5 & $27,78 \%$ & $27,78 \%$ & $16,67 \%$ \\
\hline
\end{tabular}

Na Tabela 14 são ilustrados os resultados da RNA com 7 elementos na janela de dados.

A Tabela 15 ilustra os resultados da RNA com 9 elementos na janela. 
Tabela 14 - Resultados do pré-processamento estatístico com $\mathrm{j}=7$.

\begin{tabular}{lrrr}
\hline & $5 \mathrm{n}$ & $10 \mathrm{n}$ & $20 \mathrm{n}$ \\
\hline Teste1 & $94,44 \%$ & $77,78 \%$ & $88,89 \%$ \\
Teste2 & $83,33 \%$ & $94,44 \%$ & $88,89 \%$ \\
Teste3 & $72,22 \%$ & $88,89 \%$ & $88,89 \%$ \\
Teste4 & $83,33 \%$ & $61,11 \%$ & $88,89 \%$ \\
Teste5 & $94,44 \%$ & $94,44 \%$ & $94,44 \%$ \\
\hline
\end{tabular}

Tabela 15 - Resultados do pré-processamento estatístico com j=9.

\begin{tabular}{rrrr}
\hline & $5 \mathrm{n}$ & $10 \mathrm{n}$ & $20 \mathrm{n}$ \\
\hline Teste1 & $88,89 \%$ & $83,33 \%$ & $83,33 \%$ \\
Teste2 & $77,78 \%$ & $88,89 \%$ & $83,33 \%$ \\
Teste3 & $94,44 \%$ & $88,89 \%$ & $77,78 \%$ \\
Teste4 & $77,78 \%$ & $100,00 \%$ & $77,78 \%$ \\
Teste5 & $83,33 \%$ & $88,89 \%$ & $94,44 \%$ \\
\hline
\end{tabular}

\subsubsection{Resultados do SVM para o primeiro cenário}

Os melhores resultados para o teste do cenário preliminar foram obtidos com as entradas diretas de distância, amplitude e tempo. Essas mesmas entradas foram utilizadas para o classificador SVM. As configurações desse classificador estão de acordo com o que foi exposto no capítulo anterior. Os resultados do SVM podem ser vistos na Tabela 16.

Tabela 16 - SVM: Resultados do primeiro cenário.

\begin{tabular}{ccccc}
\hline kernel & RBF & sigmóide & Polinomial & linear \\
\hline Acertos (\%) & $83,33 \%$ & $44,44 \%$ & $33,33 \%$ & $100,00 \%$ \\
\hline
\end{tabular}

\subsection{Reconhecimento da fase do processo industrial}

As redes neurais se mostram excelentes para trabalhar em soft-sensors e classificação de eventos. Em Borg (2011) uma RNA foi treinada como um soft sensor para inferir o valor da vazão de fluidos compressíveis a partir das entradas de pressão diferencial, pressão estática e da temperatura. Se a rede neural estiver trabalhando inserida em um ambiente de frame de gerenciamento de ativos, ela pode mapear fases diferentes do processo. Isso é importante para o usuário confirmar informações do processo com outros sensores. Por exemplo, para assegurar que o processo está na fase com agitação, ou com formação de espuma. Com base nesse reconhecimento/mapeamento, pode se aumentar a confiabilidade do processo e também se tem um aumento da segurança do mesmo devido à confirmação do que está acontecendo naquele momento no processo. Essa informação pode ser usada, por exemplo, para assegurar que não haja transbordo nos tanques. 


\subsection{Resultados do segundo cenário}

Analogamente ao que foi realizado para o primeiro cenário, o primeiro teste realizado com os dados do segundo cenário levaram em conta as 3 entradas de distância, amplitude e tempo como entradas para a RNA. Este cenário, por vir de uma aplicação real, com mais ruído nos dados, é mais complexo em comparação com o primeiro cenário. Por isso, decidiu-se trabalhar com mais neurônios como 10, 20 e 50 em vez dos 5, 10 e 20 anteriores. O número de testes também sofreu um aumento de 5 para 10 para cada RNA. Esse novo padrão estabelecido de número de neurônios e de testes será mantido de agora em diante para os demais cenários presentes na tese.

A Tabela 17 ilustra os resultados para a RNA com três entradas mencionadas. Cada coluna abaixo ilustra o resultado da execução de um teste. O valor apresentado se refere à porcentagem de acertos com relação ao grupo de testes que não foi apresentado na fase de treinamento da RNA. As tabelas seguintes também seguem esse padrão.

Tabela 17 - Resultados do treinamento da rede com as entradas de EP.

\begin{tabular}{lllllllllll}
\hline & \multicolumn{8}{c}{10 neurônios } \\
76,62 & 83,12 & 76,62 & 79,22 & 79,22 & 76,62 & 77,92 & 77,92 & 77,92 & 79,22 \\
\hline \multicolumn{8}{c}{} & & \multicolumn{7}{c}{20 neurônios } \\
80,52 & 77,92 & 79,22 & 75,32 & 85,71 & 77,92 & 76,62 & 84,42 & 77,92 & 77,92 \\
\hline \multirow{8}{*}{84,42} & 84,42 & 87,01 & 77,92 & 80,52 & 76,62 & 81,82 & 79,22 & 77,92 & 83,12 \\
\hline
\end{tabular}

A Tabela 18 mostra os resultados com janelas de 2 elementos.

Tabela 18 - Resultados do treinamento com as entradas de $\mu$ e $\sigma$ com elementos tomados 2 a 2 .

\begin{tabular}{|c|c|c|c|c|c|c|c|c|c|}
\hline \multicolumn{10}{|c|}{10 neurônios } \\
\hline 77,92 & 79,22 & 79,22 & 77,92 & 79,22 & 83,12 & 76,62 & 74,03 & 77,92 & 77,92 \\
\hline \multicolumn{10}{|c|}{20 neurônios } \\
\hline 76,62 & 76,62 & 77,92 & 76,62 & 80,52 & 80,52 & 79,22 & 80,52 & 83,12 & 79,22 \\
\hline \multicolumn{10}{|c|}{50 neurônios } \\
\hline 80,52 & 79,22 & 80,52 & 76,62 & 77,92 & 83,12 & 76,62 & 77,92 & 84,42 & 80,52 \\
\hline
\end{tabular}

A Tabela 19 mostra os resultados da RNA para janela de dados de 3 elementos.

Tabela 19 - Resultados do treinamento com as entradas de $\mu$ e $\sigma$ com elementos tomados 3 a 3 .

\begin{tabular}{lllllllllll}
\hline \multicolumn{10}{c}{10 neurônios } \\
85,71 & 81,82 & 84,42 & 83,12 & 81,82 & 81,82 & 80,52 & 85,71 & 83,12 & 83,12 \\
\hline 81,82 & 83,12 & 81,82 & 77,92 & 81,82 & 84,42 & 84,42 & 83,12 & 84,42 & 84,42 \\
\hline 81,82 & 81,82 & 84,42 & 83,12 & 76,62 & 83,12 & 84,42 & 81,82 & 81,82 & 80,52 \\
\hline
\end{tabular}


Na sequência, a Tabela 20 relata os resultados para o tratamento estatístico com janelas de dados de 5 em 5 elementos.

Tabela 20 - Resultados do treinamento com as entradas de $\mu$ e $\sigma$ com elementos tomados 5 a 5 .

\begin{tabular}{lllllllllll}
\hline & \multicolumn{10}{c}{10 neurônios } \\
89,61 & 89,61 & 88,31 & 92,21 & 89,61 & 88,31 & 88,31 & 89,61 & 88,31 & 90,91 \\
\hline & & & & 20 neurônios \\
87,01 & 87,01 & 88,31 & 89,61 & 88,31 & 92,21 & 90,91 & 89,61 & 89,61 & 90,91 \\
\hline & & & \multicolumn{8}{c}{50 neurônios } \\
90,91 & 92,21 & 92,21 & 89,61 & 92,21 & 89,61 & 93,51 & 93,51 & 89,61 & 93,51 \\
\hline
\end{tabular}

O penúltimo procedimento levou em conta o agrupamento de dados de 7 em 7 como mostrado na Tabela 21.

Tabela 21 - Resultados do treinamento com as entradas de $\mu$ e $\sigma$ com elementos tomados 7 a 7 .

\begin{tabular}{|c|c|c|c|c|c|c|c|c|c|}
\hline \multicolumn{10}{|c|}{10 neurônios } \\
\hline 88,31 & 90,91 & 88,31 & 89,61 & 92,21 & 92,21 & 93,51 & 87,01 & 88,31 & 85,71 \\
\hline \multicolumn{10}{|c|}{20 neurônios } \\
\hline 89,61 & 90,91 & 87,01 & 93,51 & 92,21 & 88,31 & 89,61 & 92,21 & 88,31 & 93,51 \\
\hline \multicolumn{10}{|c|}{50 neurônios } \\
\hline 88,31 & 92,21 & 90,91 & 90,91 & 89,61 & 90,91 & 93,51 & 92,21 & 90,91 & 89,61 \\
\hline
\end{tabular}

A seguir está ilustrado na Tabela 22 os resultados para o tratamento estatístico com base em janelas de 9 em 9 elementos.

Tabela 22 - Resultados do treinamento com as entradas de $\mu$ e $\sigma$ com elementos tomados 9 a 9 .

\begin{tabular}{|c|c|c|c|c|c|c|c|c|c|}
\hline \multicolumn{10}{|c|}{10 neurônios } \\
\hline 89,61 & 88,31 & 92,21 & 85,71 & 85,71 & 88,31 & 87,01 & 85,71 & 87,01 & 85,71 \\
\hline \multicolumn{10}{|c|}{20 neurônios } \\
\hline 88,31 & 92,21 & 92,21 & 88,31 & 88,31 & 88,31 & 90,91 & 92,21 & 90,91 & 85,71 \\
\hline \multicolumn{10}{|c|}{50 neurônios } \\
\hline 89,61 & 90,91 & 90,91 & 90,91 & 89,61 & 89,61 & 89,61 & 88,31 & 90,91 & 88,31 \\
\hline
\end{tabular}

\subsubsection{Resultados do SVM para o segundo cenário.}

Na Tabela 23 podem ser vistos os resultados do SVM para o segundo cenário. Os melhores resultados da RNA foram os que utilizaram as 29 entradas com os pré-processamento de janelas de 2, 3, 5, 7 e 9 elementos. Esses mesmos dados foram utilizados para o classificador SVM. 
Tabela 23 - SVM: Resultados do segundo cenário.

\begin{tabular}{ccccc}
\hline kernel & RBF & sigmóide & Polinomial & linear \\
\hline \multicolumn{5}{c}{ janelas de 2 em 2 elementos } \\
Acertos (\%) & $75,32 \%$ & $75,32 \%$ & $75,32 \%$ & $75,32 \%$ \\
\hline \multicolumn{5}{c}{ janelas de 3 em 3 elementos } \\
Acertos (\%) & $75,32 \%$ & $81,82 \%$ & $75,32 \%$ & $75,32 \%$ \\
\hline \multicolumn{5}{c}{ janelas de 5 em 5 elementos } \\
Acertos (\%) & $75,32 \%$ & $84,41 \%$ & $75,32 \%$ & $75,32 \%$ \\
\hline \multicolumn{5}{c}{ janelas de 7 em 7 elementos } \\
Acertos (\%) & $75,32 \%$ & $84,41 \%$ & $75,32 \%$ & $75,32 \%$ \\
\hline \multicolumn{5}{c}{ janelas de 9 em 9 elementos } \\
Acertos (\%) & $75,32 \%$ & $81,82 \%$ & $75,32 \%$ & $75,32 \%$ \\
\hline \multicolumn{5}{c}{}
\end{tabular}

\subsection{Resultados do terceiro cenário}

Como informado anteriormente, os dados dessa indústria vieram da fábrica de radares. Os mesmos procedimentos do segundo cenário foram desenvolvidos com os dados do terceiro cenário que apresenta um número superior de dados em comparação com o segundo. Na Tabela 24 estão relatados os resultados para o tratamento estatístico seguindo-se janelas de 2 em 2 elementos e a Tabela 25 relata os resultados para o procedimento com janelas de 3 em 3 elementos.

Tabela 24 - Resultados do treinamento com as entradas de $\mu$ e $\sigma$ com elementos tomados 2 a 2 .

\begin{tabular}{|c|c|c|c|c|c|c|c|c|c|}
\hline \multicolumn{10}{|c|}{10 neurônios } \\
\hline 92,62 & 94,00 & 94,79 & 94,58 & 94,87 & 94,66 & 94,54 & 94,62 & 94,75 & 94,58 \\
\hline \multicolumn{10}{|c|}{20 neurônios } \\
\hline 94,50 & 94,50 & 94,37 & 94,54 & 94,54 & 94,79 & 94,79 & 94,62 & 94,41 & 94,00 \\
\hline \multicolumn{10}{|c|}{50 neurônios } \\
\hline 94,46 & 94,41 & 94,50 & 94,83 & 94,58 & 91,37 & 94,66 & 93,83 & 94,54 & 94,62 \\
\hline
\end{tabular}

Tabela 25 - Resultados do treinamento com as entradas de $\mu$ e $\sigma$ com elementos tomados 3 a 3 .

\begin{tabular}{|c|c|c|c|c|c|c|c|c|c|}
\hline \multicolumn{10}{|c|}{10 neurônios } \\
\hline 99,42 & 99,62 & 99,54 & 99,67 & 99,54 & 99,37 & 99,67 & 99,50 & 98,75 & 99,67 \\
\hline \multicolumn{10}{|c|}{20 neurônios } \\
\hline 99,58 & 99,50 & 99,54 & 99,54 & 99,58 & 99,33 & 99,75 & 99,58 & 99,54 & 99,12 \\
\hline \multicolumn{10}{|c|}{50 neurônios } \\
\hline 99,42 & 99,29 & 99,42 & 99,50 & 99,42 & 99,58 & 99,50 & 99,50 & 99,29 & 99,46 \\
\hline
\end{tabular}

Na Tabela 26 estão relatados os resultados para os procedimentos com base no janelamento de 5 elementos. A Tabela 27 ilustra os resultados para janelas de 7 elementos e a Tabela 28 relata os resultados para a programação realizada com dados em janelas de 9 em 9 elementos. 
Tabela 26 - Resultados do treinamento com as entradas de $\mu$ e $\sigma$ com elementos tomados 5 a 5 .

\begin{tabular}{|c|c|c|c|c|c|c|c|c|c|}
\hline \multicolumn{10}{|c|}{10 neurônios } \\
\hline 93,12 & 93,79 & 93,71 & 93,16 & 93,71 & 93,75 & 93,41 & 93,62 & 93,37 & 93,71 \\
\hline \multicolumn{10}{|c|}{20 neurônios } \\
\hline 93,66 & 93,62 & 93,41 & 93,54 & 93,37 & 93,50 & 93,46 & 81,20 & 93,41 & 93,83 \\
\hline \multicolumn{10}{|c|}{50 neurônios } \\
\hline 93,00 & 93,58 & 93,29 & 93,29 & 93,46 & 93,29 & 93,66 & 93,04 & 93,29 & 93,37 \\
\hline
\end{tabular}

Tabela 27 - Resultados do treinamento com as entradas de $\mu$ e $\sigma$ com elementos tomados 7 a 7 .

\begin{tabular}{|c|c|c|c|c|c|c|c|c|c|}
\hline \multicolumn{10}{|c|}{10 neurônios } \\
\hline 91,70 & 91,83 & 92,37 & 91,83 & 92,21 & 92,08 & 92,25 & 92,25 & 91,37 & 91,95 \\
\hline \multicolumn{10}{|c|}{20 neurônios } \\
\hline 92,08 & 91,45 & 92,29 & 92,21 & 92,16 & 91,91 & 91,79 & 92,08 & 91,83 & 91,87 \\
\hline \multicolumn{10}{|c|}{50 neurônios } \\
\hline 92,00 & 92,12 & 91,75 & 92,21 & 91,87 & 92,12 & 91,91 & 91,75 & 91,37 & 91,95 \\
\hline
\end{tabular}

Tabela 28 - Resultados do treinamento com as entradas de $\mu$ e $\sigma$ com elementos tomados 9 a 9 .

\begin{tabular}{|c|c|c|c|c|c|c|c|c|c|}
\hline \multicolumn{10}{|c|}{10 neurônios } \\
\hline 91,45 & 90,79 & 91,50 & 91,00 & 90,95 & 91,50 & 91,12 & 90,91 & 91,20 & 90,83 \\
\hline \multicolumn{10}{|c|}{20 neurônios } \\
\hline 91,20 & 91,08 & 91,29 & 90,83 & 91,41 & 91,50 & 91,33 & 90,95 & 91,16 & 91,41 \\
\hline \multicolumn{10}{|c|}{50 neurônios } \\
\hline 91,79 & 91,45 & 91,37 & 91,25 & 91,58 & 91,83 & 91,37 & 91,54 & 90,95 & 91,20 \\
\hline
\end{tabular}

\subsubsection{Resultados do SVM para o terceiro cenário}

Os melhores resultados da RNA do terceiro cenário foram os que tiveram como entrada os valores pré-processados de média e de desvio-padrão com a técnica de janelamento de 2, 3, 5, 7 e 9 elementos. Esses mesmos dados foram utilizados para o classificador SVM e os resultados desse estão expostos na Tabela 29 . 
Tabela 29 - SVM: Resultados do terceiro cenário.

\begin{tabular}{ccccc}
\hline kernel & RBF & sigmóide & Polinomial & linear \\
\hline \multicolumn{5}{c}{ janelas de 2 em 2 elementos } \\
Acertos (\%) & $84,49 \%$ & $89,78 \%$ & $84,49 \%$ & $84,49 \%$ \\
\hline \multicolumn{5}{c}{ janelas de 3 em 3 elementos } \\
Acertos (\%) & $85,99 \%$ & $93,74 \%$ & $84,49 \%$ & $84,49 \%$ \\
\hline \multicolumn{5}{c}{ janelas de 5 em 5 elementos } \\
Acertos (\%) & $85,70 \%$ & $90,87 \%$ & $84,49 \%$ & $84,83 \%$ \\
\hline \multicolumn{5}{c}{ janelas de 7 em 7 elementos } \\
Acertos (\%) & $88,70 \%$ & $89,45 \%$ & $84,49 \%$ & $84,45 \%$ \\
\hline \multicolumn{5}{c}{ janelas de 9 em 9 elementos } \\
Acertos (\%) & $89,12 \%$ & $88,91 \%$ & $84,49 \%$ & $84,57 \%$ \\
\hline
\end{tabular}

\subsection{Resultados do quarto cenário}

Os procedimentos utilizados nos dois cenários anteriores foram aplicados à esse último cenário cujos dados são oriundos da fábrica da Rosemount na Suécia. A quantidade de dados dessa aplicação real superam os das aplicações anteriores. Na Tabela 30 estão relatados os resultados para o tratamento estatístico com janelas de 2 em 2 elementos.

Tabela 30 - Resultados do treinamento com as entradas de $\mu$ e $\sigma$ com elementos tomados 2 a 2 .

\begin{tabular}{|c|c|c|c|c|c|c|c|c|c|}
\hline \multicolumn{10}{|c|}{10 neurônios } \\
\hline 89,14 & 89,35 & 89,34 & 89,34 & 89,37 & 89,45 & 89,46 & 89,34 & 89,45 & 89,35 \\
\hline \multicolumn{10}{|c|}{20 neurônios } \\
\hline 89,45 & 89,49 & 89,36 & 89,48 & 89,53 & 97,35 & 97,28 & 97,27 & 97,21 & 97,22 \\
\hline \multicolumn{10}{|c|}{50 neurônios } \\
\hline 13,25 & 13,25 & 13,25 & 13,25 & 13,25 & 89,20 & 89,48 & 89,34 & 89,46 & 89,42 \\
\hline
\end{tabular}

A Tabela 31 relata os resultados considerando-se janelas de 3 em 3 elementos.

Tabela 31 - Resultados do treinamento com as entradas de $\mu$ e $\sigma$ com elementos tomados 3 a 3 .

\begin{tabular}{|c|c|c|c|c|c|c|c|c|c|}
\hline \multicolumn{10}{|c|}{10 neurônios } \\
\hline 97,84 & 97,84 & 98,02 & 97,98 & 97,77 & 97,84 & 98,08 & 97,98 & 98,00 & 98,01 \\
\hline \multicolumn{10}{|c|}{20 neurônios } \\
\hline 65,73 & 65,80 & 65,81 & 65,83 & 65,78 & 92,20 & 92,25 & 92,15 & 92,16 & 92,23 \\
\hline \multicolumn{10}{|c|}{50 neurônios } \\
\hline 98,06 & 98,07 & 98,06 & 98,06 & 98,07 & 97,99 & 98,05 & 98,00 & 98,06 & 98,02 \\
\hline
\end{tabular}

Considerando-se janelas com 5 elementos, tem-se os resultados indicados na Tabela 32. 
Tabela 32 - Resultados do treinamento com as entradas de $\mu$ e $\sigma$ com elementos tomados 5 a 5 .

\begin{tabular}{lllllllllll}
\hline & \multicolumn{10}{c}{10 neurônios } \\
87,70 & 87,65 & 87,64 & 87,46 & 87,66 & 87,59 & 87,64 & 87,46 & 87,66 & 87,59 \\
\hline 99,92 & 99,90 & 99,85 & 99,91 & 99,90 & 99,85 & 99,91 & 99,93 & 99,94 & 70,23 \\
\hline \multirow{2}{*}{87,29} & 87,49 & 87,58 & 87,38 & 87,37 & 87,49 & 87,64 & 87,38 & 87,57 & 87,48 \\
\hline
\end{tabular}

Na Tabela 33 estão relatados os resultados para o tratamento estatístico com janelamento de dados de 7 em 7 elementos.

Tabela 33 - Resultados do treinamento com as entradas de $\mu$ e $\sigma$ com elementos tomados 7 a 7 .

\begin{tabular}{lllllllllll}
\hline & \multicolumn{10}{c}{10 neurônios } \\
84,72 & 84,75 & 84,74 & 84,67 & 84,75 & 84,78 & 84,88 & 84,97 & 84,78 & 84,66 \\
\hline 84,65 & 84,65 & 84,91 & 84,53 & 84,95 & 84,94 & 85,04 & 84,89 & 84,81 & 84,71 \\
\hline 84,72 & 84,73 & 85,13 & 84,78 & 84,73 & 84,67 & 84,45 & 84,71 & 84,71 & 84,73 \\
\hline
\end{tabular}

O procedimento de treinamento da rede utilizando-se agrupamentos de 9 elementos tem seus resultados indicados na Tabela 34 .

Tabela 34 - Resultados do treinamento com as entradas de $\mu$ e $\sigma$ com elementos tomados 9 a 9 .

\begin{tabular}{lllllllllll}
\hline & \multicolumn{8}{c}{10 neurônios } \\
84,20 & 84,22 & 84,42 & 84,42 & 84,39 & 83,91 & 84,21 & 84,41 & 84,18 & 84,08 \\
\hline 84,58 & 84,30 & 84,21 & 84,18 & 84,29 & 84,28 & 84,35 & 84,18 & 83,85 & 84,08 \\
\hline 83,78 & 84,15 & 84,09 & 84,22 & 84,23 & 84,03 & 84,14 & 84,09 & 84,22 & 84,09 \\
\hline
\end{tabular}

\subsubsection{Resultados do SVM para o quarto cenário}

A Tabela 35 apresenta os resultados da classificação do SVM aplicada aos dados da indústria do quarto cenário. 
Tabela 35 - SVM: Resultados do quarto cenário.

\begin{tabular}{ccccc}
\hline kernel & RBF & sigmóide & Polinomial & linear \\
\hline \multicolumn{5}{c}{ janelas de 2 em 2 elementos } \\
Acertos (\%) & $84,84 \%$ & $88,30 \%$ & $77,97 \%$ & $82,74 \%$ \\
\hline \multicolumn{5}{c}{ janelas de 3 em 3 elementos } \\
Acertos (\%) & $89,72 \%$ & $96,40 \%$ & $78,06 \%$ & $86,09 \%$ \\
\hline \multicolumn{5}{c}{ janelas de 5 em 5 elementos } \\
Acertos (\%) & $82,42 \%$ & $85,71 \%$ & $78,02 \%$ & $81,80 \%$ \\
\hline \multicolumn{5}{c}{ janelas de 7 em 7 elementos } \\
Acertos (\%) & $81,50 \%$ & $82,37 \%$ & $78,01 \%$ & $81,50 \%$ \\
\hline \multicolumn{5}{c}{ janelas de 9 em 9 elementos } \\
Acertos (\%) & $81,40 \%$ & $81,46 \%$ & $77,99 \%$ & $81,46 \%$ \\
\hline
\end{tabular}

\subsection{Comparação dos resultados dos classificadores}

Na Tabela 36 estão apresentadas as ocorrências dos melhores resultados da RNA e do SVM para os quatro cenários considerados.

Tabela 36 - Comparação do desempenho dos classificadores

\begin{tabular}{lccl}
\hline \multicolumn{1}{c}{ Cenário } & Classificador & $\begin{array}{c}\text { Melhor } \\
\text { resultado }\end{array}$ & \multicolumn{1}{c}{ Ocorrências } \\
\hline Primeiro & RNA & $100,00 \%$ & 3 oc. $5 \mathrm{n}, 7$ oc. 10n e 6 oc. 20n \\
Primeiro & SVM & $100,00 \%$ & 1 oc. linear \\
Segundo & RNA & $93,51 \%$ & 3 oc. J5/50n, 1 oc. j7/10n, \\
(continuação) & & & 2 oc. J7/20n e 1 oc. J7/50n \\
Segundo & SVM & $84,41 \%$ & 1 oc. J5/sigmóide e 1 oc. J7/ sigmóide \\
Terceiro & RNA & $99,75 \%$ & 1 oc. J3/20n \\
Terceiro & SVM & $93,74 \%$ & 1 oc. J3/sigmóide \\
Quarto & RNA & $99,94 \%$ & 1 oc. J5/20n \\
Quarto & SVM & $96,40 \%$ & 1 oc. J3/sigmóide \\
\hline
\end{tabular}

Para a Tabela 36, "J" resume o número de dados na janela e "n" é o número de neurônios. Por exemplo, "3 oc. 5n" para o teste preliminar informa que existem 3 ocorrências do valor máximo de $100 \%$ de acertos para a rede com 5 neurônios. Para esse cenário não foi realizado o tratamento estatístico devido ao fato dos melhores resultados da RNA não figurarem nesse teste, por isso não aparece a indicação do janelamento. Considerando outro exemplo, "1 oc. J3/20n" para o terceiro cenário significa que existe uma ocorrência do melhor resultado de 99,75\% no tratamento estatístico de 3 em 3 elementos nos dados que serviram de entrada para a RNA de 20 neurônios. 
Uma comparação de tempos de treinamento pode ser realizada entre a classificação da RNA e do SVM. Tanto o Weka como o Matlab mostram os tempos de treinamento resultantes. Para o SVM foi considerado o kernel RBF e para a RNA, a rede com 50 neurônios, que é a mais demorada para se treinar. Ambos os testes foram realizados num computador com processador i7 e 8 GB de memória RAM. Serão considerados os experimentos com os dados reais compreendendo os cenários 2, 3 e 4.

Para o segundo cenário os tempos foram da ordem de 0,03 segundos para o SVM e de 2 segundos e treze milissegundos para a RNA com 11 épocas. Para o terceiro cenário foram registrados 18 s e $50 \mathrm{~ms}$ para o SVM e 3 min e 23 segundos para a RNA com 141 épocas. No caso do quarto cenário, o tempo de execução do SVM foi de $33 \mathrm{~s}$ e da RNA foi de 30 minutos e 37 segundos com 182 épocas.

Como mostrado em Borg (2011), onde o aprendizado de uma rede neural foi distribuída num ambiente de cálculos do foundation fieldbus, depois do treinamento realizado, somente a fase forward é empregada para mostrar os resultados da rede. Os cálculos dessa fase são praticamente multiplicações matriciais que podem ser realizadas em poucos segundos ou até menos que isso. Somente se houver alterações das características classificadas, no caso de se adicionar, por exemplo, uma nova classificação ou se houver alterações significativas no tanque, reposicionamento do radar ou troca do fluido por outro de características diferentes, é que seria necessário se retreinar a RNA ou o SVM. Assim, mesmo o tempo de aproximadamente meia hora, que é o maior tempo gasto para a rede de 50 neurônios do quarto cenário, não é um impeditivo para a utilização da técnica em sistemas de gerenciamento de ativos.

Pelos testes realizados, é possível concluir-se que, principalmente, para grandes volumes de dados como os do cenário 3 e 4, o tempo de resposta de treinamento do SVM é significativamente menor que o da RNA.

\subsection{Aplicação da norma NAMUR NE107 às classifi- cações obtidas}

A partir das classificações obtidas é possível utilizar a técnica apresentada em conjunto com a simbologia padronizada pela norma NAMUR NE107 para mostrar um alerta para o grupo de operadores e de manutenção.

A Tabela 37 até a Tabela 40 ilustram uma sugestão de se mostrar os ícones recomendados pela NAMUR para reportar as diferentes classificações dos problemas. Para o primeiro cenário, o símbolo de falha associado ao tag do instrumento tipo radar na tela do sistema supervisório é indicado, uma vez que nessa condição, a espuma invalidará a medição e é necessário que o operador saiba que o valor da variável do processo nesse momento não estará condizente com o valor do nível no processo. Para o grupo de manutenção, será enviada uma mensagem emergencial para que seja feita a limpeza da antena. No caso 
Tabela 37 - Sugestão de implementação da NAMUR NE107 aplicada às classificações de problemas. Primeiro cenário.

\begin{tabular}{ccc}
\hline & Primeiro cenário & \\
\hline Classificação & $\begin{array}{c}\text { Mensagem } \\
\text { para } \\
\text { operação }\end{array}$ & $\begin{array}{c}\text { Mensagem } \\
\text { para } \\
\text { Manutenção }\end{array}$ \\
\hline Sem problemas & Nenhuma mensagem & Nenhuma mensagem \\
\hline Agitação & Fase de agitação & Nenhuma mensagem \\
\hline Espuma & Presença de espuma & Nenhuma mensagem \\
\hline Muita espuma & $\bigotimes$ & $\begin{array}{c}\text { Limpeza } \\
\text { na antena }\end{array}$ \\
Presença & da antena \\
de espuma & & Agendar \\
na antena & limpeza \\
\hline
\end{tabular}

Tabela 38 - Sugestão de implementação da NAMUR NE107 aplicada às classificações de problemas. Segundo cenário.

\begin{tabular}{ccc}
\hline & Segundo cenário & \\
\hline \multirow{2}{*}{ Classificação } & Mensagem & Mensagem \\
& para & para \\
& operação & Manutenção \\
\hline Sem problemas & Nenhuma mensagem & Nenhuma mensagem \\
\hline Vapor e agitação & Presença de Vapor e Agitação & Nenhuma mensagem \\
\hline
\end{tabular}

Tabela 39 - Sugestão de implementação da NAMUR NE107 aplicada às classificações de problemas. Terceiro cenário.

\begin{tabular}{ccc}
\hline & Terceiro cenário & \\
\hline Classificação & $\begin{array}{c}\text { Mensagem } \\
\text { para } \\
\text { operação }\end{array}$ & $\begin{array}{c}\text { Mensagem } \\
\text { para } \\
\text { Manutenção }\end{array}$ \\
\hline Sem problemas & Nenhuma mensagem & Nenhuma mensagem \\
\hline Alta variação na amplitude do eco & Alta variação do eco & Nenhuma mensagem \\
\hline $\begin{array}{c}\text { Baixa } \\
\text { do eco }\end{array}$ & $\begin{array}{c}\text { Verificar limpeza e } \\
\text { posicionamento da antena; } \\
\end{array}$ & $\begin{array}{c}\text { Verificar tensão de alimenta- } \\
\text { ção do radar; } \\
\text { Verificar se o fluido } \\
\text { do tanque foi alterado; }\end{array}$ \\
\hline
\end{tabular}

Tabela 40 - Sugestão de implementação da NAMUR NE107 aplicada às classificações de problemas. Quarto cenário.

\begin{tabular}{|c|c|c|}
\hline & Quarto cenário & \\
\hline \multirow{3}{*}{ Classificação } & Mensagem & Mensagem \\
\hline & para & para \\
\hline & operação & Manutenção \\
\hline Sem problemas & Nenhuma mensagem & Nenhuma mensagem \\
\hline Alta variação na amplitude do eco & Alta variação do eco & Nenhuma mensagem \\
\hline \multirow{6}{*}{$\begin{array}{c}\text { Baixa } \\
\text { amplitude } \\
\text { do eco }\end{array}$} & & Verificar limpeza e \\
\hline & & posicionamento da antena; \\
\hline & & Verificar tensão de alimenta- \\
\hline & & ção do radar; \\
\hline & & Verificar se o fluido \\
\hline & & do tanque foi alterado; \\
\hline
\end{tabular}


de se classificar espuma na antena, mas não tão severamente como no caso anteriormente citado, deve-se mostrar ao operador que há a necessidade de se fazer alguma manutenção no campo e, para o grupo de manutenção, será enviada a mensagem para um agendamento de limpeza da antena. Outras classificações como agitação e presença de espuma no processo que não causam nenhum problema na operação, podem ser informados ao operador, para que ele acompanhe e tenha como verificar a situação do processo. Não é necessário informar ao pessoal de manutenção. No segundo cenário, a informação de que há presença de vapor e de agitação é interessante ao operador para ele verificar se o processo deveria ter essas características naquele momento. No entanto, não é necessário o envio dessa informação ao grupo de manutenção. Para o terceiro e quarto cenários, quando uma alta variação da amplitude do eco ocorrer, é importante que essa informação chegue ao operador, porém, não necessita a entrega dela ao pessoal de manutenção. No caso de baixa amplitude do eco, isso pode causar perda da leitura do valor da distância medida. O valor medido da amplitude está abaixo do que é recomendado para uma boa medição. É importante informar ao operador e pedir à manutenção verificar se a antena não está suja ou obstruída, se a antena não foi reposicionada, se ao radar está fornecida uma faixa de tensão compatível e se o fluido não foi alterado por outro cuja constante dielétrica seja mais baixa. Essas verificações podem ajudar a se elevar o valor baixo de amplitude do sinal do eco. 


\section{Conclusão}

A técnica desenvolvida indica que a RNA e o SVM, aliados à pre-processamento estatístico dos dados, conseguem identificar e classificar corretamente os problemas em aplicações de medição de nível com o radar de propagação de onda livre nos quatro cenários apresentados.

Para o primeiro cenário, realizado em um ambiente controlado, onde todas as fases do processo eram bem conhecidas, e sem problemas de ruídos, foi possível se chegar a 100\% de acertos com a rede neural com 5, 10 e 20 neurônios com relação às saídas desejadas. O SVM também atingiu esse patamar com o kernel linear.

Para o segundo cenário, chegou-se a 93,51\% de acertos com a rede de 50 neurônios e técnicas de pré-processamento estatístico de janelas de dados de 5 elementos e de redes de 10, 20 e 50 neurônios com janelas de 7 elementos. O SVM para esse cenário atingiu seu melhor resultado de 84,41\% com o kernel sigmóide e janelas de 5 e 7 elementos.

Com relação ao terceiro cenário, os melhores resultados foram obtidos com a RNA de 20 neurônios atingindo a taxa de acertos de 99,75 \% e o SVM de 93,74 \% com o kernel sigmóide. Ambos resultados foram conseguidos com janelas de 3 elementos.

O quarto cenário teve acertos de 99,94 \% com 20 neurônios e janelas de 5 elementos e o SVM de 96,40 \% utilizando o kernel sigmóide e janela de 3 elementos.

Para o primeiro cenário foi possível demonstrar também o mapeamento das fases do processo como enchimento, agitação, espuma e outras. Essas confirmações podem ser empregadas como um soft-sensor indicando ao operador da planta industrial em que fase o processo está. Além de melhorar a confiabilidade da medição de nível, proporciona um aumento de segurança da planta, por exemplo, por ajudar a evitar transbordamento dos tanques. Para os demais cenários, também foi possível demonstrar o reconhecimento de que há um problema de medição como presença de vapor intenso e de agitação para o segundo cenário, valores de amplitude muito baixas e de uma variação alta do sinal do eco para os terceiro e quarto cenários. Embora esses três últimos cenários não tiveram toda a riqueza de detalhes das fases conseguida no primeiro cenário por não ter as informações detalhadas disponíveis das diferentes fases. 
Para o terceiro cenário foi realizada a reinstalação do radar em uma garrafa, o que viabilizou a utilização do radar nessa aplicação. Embora a concentração de vapor e a agitação sejam situações desafiadoras para a utilização do radar, seus níveis atuais não impedem o funcionamento do medidor. Caso haja um aumento da quantidade de vapor, uma tela de teflon poderia ser colocada na antena para diminuir a quantidade de vapor que chega à antena.

Para os dois últimos cenários, uma antena maior que poderia ser de 3 ou 4 polegadas de diâmetro para o terceiro cenário que utiliza uma de 2 polegadas e uma de 4 polegadas de diâmetro para o quarto cenário que atualmente usa uma de 3 polegadas, além de melhorar o ganho da antena e de diminuir o ângulo do feixe das micro-ondas, proporciona uma área maior de recepção dos ecos. Isso aumenta a amplitude dos sinais recebidos melhorando o problema de baixas amplitudes.

Embora o SVM tenha apresentado bons resultados e tempos de treinamento menores que o das RNAs, essas tiveram um desempenho melhor, atingindo taxas mais altas de acertos. A partir desses resultados, pode-se propor o uso dessa técnica para trabalhar embarcada em softwares de gerenciamento de ativos seguindo diretrizes de classificação de problemas de medição, como a sugerida pela Tabela 37. A implementação dessa técnica inserida em um software de gerenciamento de ativos seria um possível trabalho futuro para continuidade da Tese presente. 


\section{Referências}

ALTUN, I.; TSOCHANTARIDIS, I.; Y.; HOFMANN, T. Hidden markov support vector machines. In: INTERNATIONAL CONFERENCE ON MACHINE LEARNING, 20. 2003. Washington. Proceedings... Mento Park: AAAI, 2003. p. 3-10. 2003.

ANDREWS, I.; TSOCHANTARIDIS, I.; HOFMANN, T. Support vector machines for multiple-instance learning. In: BECKER, S.; THRUN, S.; OBERMAYER, K.(Ed.) Advances in neural information processing systems, 15. New York: MIT Press, 2003. (NIPS15). Disponível em: <www.robots.ox.ac.uk $/{ }^{\sim} \mathrm{vgg} / \mathrm{rg} /$ papers/andrews_etal_NIPS02.pdf>. Acesso em: 6 Apr. 2015.

BERGE, J. Increasing operator effectiveness. 2014. Disponível em: <http://www.ceasiamag.com/article/increasing-operator-effectiveness/10440>. Acesso em: 10 May 2015 .

BERNARDINISYX M. I. JORDANY, A. S. V. F. D. Support vector machines for analog circuit performance representation. 2003. Disponível em: < https://embedded.eecs.berkeley.edu/Respep/Research/asves/paper2003/Debernardinis_dac03.pdf > . Acesso em: 14 Feb. 2014.

BLOCH, G. et al. Neural intelligent control for a steel plant. IEEE Transactions on neural networks. v. 8, n. 4, p. 910-918. 1997.

BORG, D. Implementação de uma rede neural em ambiente Foundation Fieldbus para computação de vazão simulando um transmissor multivariável. 2011. 144p. Dissertação (Mestrado) — Escola de Engenharia de São Carlos, Universidade de São Paulo, São Carlos, 2011.

BORG, D. et al. Aplicação de redes neurais para detecção de linhas de impulso entupidas em medições de vazão. In: CONGRESSO INTERNACIONAL DE AUTOMAÇÃO, SISTEMAS E INSTRUMENTAÇÃO, 13. 2009, São Paulo Anais... 2009.

BOSER, B. E.; GUYON, I. M.; VAPNIK, V. N. A training algorithm for optimal margin classifiers. In: ACM WORKSHOP ON COMPUTATIONAL LEARNING THEORY, 5.,1992. Procedings... 1992. p. 144-152.

BOTTOU, C. J. L. L. Support vector machine solvers. 2007. Disponível em: <www.csie.ntu.edu.tw/ ${ }^{\sim}$ cjlin/papers/bottou_lin.pdf>. Acesso em: 14 Feb. 2014. 
BURGES, C. J. A tutorial on support vector machines for pattern recognition. Data mining and knowledge discovery 2. 1998. p. 121-167.

CARULLO, A. et al. Ultrasonic distance sensor improvement using a two-level neural-network. IEEE Transactions on Instrumentation and Measurement, 1996. v. 45, n. 2, p. 677-682, Apr. 1996.

CATENI, S.; COLLA, V.; VANNUCCI, M. A method for resampling imbalanced datasets in binary classification tasks for real-world problems. Neurocomputing, 2014. Elsevier, v. 135, p. 32-41, 2014. Disponível em: <http://dx.doi.org/10.1016/j.neucom$.2013 .05 .059>$.

CHANG, C. C.; LIN, C. J. LIBSVM: A library for support vector machines. 2013.

Disponível em: <www.csie.ntu.edu.tw/ ${ }^{\sim}$ cjlin/papers/libsvm.pdf.>.. Acesso em: 14 Feb. 2014.

CHEN, R. C. et al. Using rough set and support vector machine for network intrusion detection. In: International journal of network security \& its applications (IJNSA). v. 1, n. 1, Apr. 2009.

Disponível em: <http://www.utdallas.edu/ ${ }^{\sim}$ lkhan/papers/Effective\%20Intrusion\%20Detection\%20Using\%20Support\%20Vector\%20Machines.pdf $>$.

COTTER, A.; SHWARTZ, S. S.; SREBRO, N. Learning optimally sparse support vector machines. 2013.

CRISTIANINI, N.; SHAWE-TAYLOR, J. An introduction to support vector machines and other kernel-based learning methods. Cambridge university press, 2002.

DALCI, K. B.; GULEZ, K.; MUMCU, T. V. The design of the measurement circuit using ultrasonic sound waves for fuel level of automobile tanks and the detection of bad sectors of tank by neural networks. In: SICE ANNUAL CONFERENCE. 2004. v. 2, p. 1056-1060. Proceedings... 2004.

D'EMILIA, G.; MARRA, A.; NATALE, E. Use of neural networks for quick and accurate auto-tuning of PID controller. Robotics and computer-integrated manufacturing, 2007. v. 23, n. 2, p. 170-179, 2007.

ENDRESS\&HAUSER. NAMUR recomendations. 2011. 35 p. Disponível em: $<$ www.fieldbus.org/images/stories/international/asiapacific/India/presentations/a2011 \_7\ff \_devices \_\namur \_107.pdf>. Acesso em: 14 Feb. 2014.

FALDELLA, E.; TUCCI, P. A model-driven approach to automated diagnosis of industrial distributed I/O systems based on fieldbus technologies. ICAT INTERNATIONAL SYMPOSIUM ON INFORMATION, COMMUNICATION AND AUTOMATION TECHNOLOGIES, 22, 2009. Proceedings... 2009.

FISHER, R. Contributions to Mathematical Statistics. Wiley, 1988.

GONZAGA, J. C. B. et al. ANN-based soft-sensor for real-time process monitoring and control of an industrial polymerization process. Computers and chemical engineering, 2009. v. 33, n. 1, p. 43-49, 2009. 
HAYKIN, S. Neural networks and learning machines. 3. ed. Prentice Hall, 2008.

HAYT, W. H. J. Eletromagnetismo. 4a ed. Rio de Janeiro: LTC, 1995.

HSU, C. W.; CHANG, C. C.; LIN, C. J. A practical guide to support vector classification. 2010. Disponível em: <http://www.csie.ntu.edu.tw/ ${ }^{\sim}$ cjlin>. Acesso em: 14 Feb. 2014.

HSU, C. W.; LIN, C. J. A comparison of methods for multi-class support vector machines. 2008. Disponível em: <csie.ntu.edu.tw>. Acesso em: 14 Feb. 2014.

ILIYAS, S. et al. RBF neural network inferential sensor for process emission monitoring. Control engineering practice, 2013. Elsevier, v. 21, n. 7, p. 962-970, 2013. Disponível em: <http://dx.doi.org/10.1016/j.conengprac.2013.01.007>.

KIELB, J. Application of a $25 \mathrm{GHz}$ FMCW radar for industrial control and process level measurement. MICROWAVE SYMPOSIUM DIGEST, IEEE MTT-S INTERNATIONAL, v. 1, 1999. Proceedings... 1999.

KIM, S. D.; LEE, J. H. Performance analysis of FMCW-UWB radar for oil tank level gauge. In: ACIS/JNU INTERNATIONAL CONFERENCE ON COMPUTERS, NETWORKS, SYSTEMS AND INDUSTRIAL ENGINEERING. CNSI. p. 129-132, 2001. Proceedings... 2011.

KRAUS, J. D. Antenas. Rio de Janeiro: Editora guanabara dois, 1983.

LV BAOPING TANG, Y. Z. Z.; ZHOU, C. A novel method for mechanical fault diagnosis based on variational mode decomposition and multikernel support Vector Machine. In: HINDAWI PUBLISHING CORPORATION SHOCK AND VIBRATION. 2016. Disponível em: <http://dx.doi.org/10.1155/2016/3196465>.

MANDERS, E.; BARFORD, L. Diagnosis of a continuous dynamic system from distributed measurements. In: IEEE INSTRUMENTATION AND MEASUREMENT TECHNOLOGY CONFERENCE, 17, v. 2, p. 546-551, 2000. Proceedings... 2000.

MIRABELLA, O.; RAUCEA, A. An interactive tool for the study of the fieldbus impact on a steam turbine-based current generator. IEEE International conference on e-learning in industrial electronics, 1. ICELIE, 2006. p. 119-124.

MITCHEM, J. Automated calibration aids smoth turnover of new plants. IEEE Instrumentation \& measurement magazine. Dec. 2004, p. 26-29.

NAJAFI, M.; CULP, C.; LANGARI, R. Enhanced auto-associative neural networks for sensor diagnostics (E-AANN). IEEE INTERNATIONAL CONFERENCE ON FUZZY SYSTEMS, v. 1, p. 453-456, 2004. Proceedings... 2004

NAMUR EMPFEHLUNG = NAMUR RECOMENDATION. NE 107: Selbstüberwachung und diagnose von Feldgeräten $=$ Self-monitoring and diagnosis of field devices. Namur, 2006.

NEMARICH, C. P. Time domain reflectometry liquid level sensors. IEEE Instrumentation \& measurement magazine. Dec. 2001. p. 40-44. 
PANI, A. K.; MOHANTA, H. K. A hybrid soft sensing approach of a cement mill using principal component analysis and artificial neural networks. ADVANCE COMPUTING CONFERENCE (IACC), IEEE INTERNATIONAL, 3. p. 713-718, 2012. Proceedings... 2012.

PAVIGLIANITI, G.; PIERRI, F. Sensor fault detection and isolation for chemical batch reactors. CONFERENCE ON COMPUTER AIDED CONTROL SYSTEM DESIGN, IEEE INTERNATIONAL CONFERENCE ON CONTROL APPLICATIONS, IEEE INTERNATIONAL SYMPOSIUM ON INTELLIGENT CONTROL, 1, p. 0-5, 2006. Proceedings... 2006.

PLATT, J. C. Fast training of support vector machines using sequential minimal optimization. 2000. Disponível em: <http://www.research.microsoft.com/_jplatt>. Acesso em: 12 Feb. 2014.

POPPER, K. The Logic of Scientific Discovery. Springer, 1959.

PRAKASH, J.; PATWARDHAN, S. C.; SHAH, S. L. Design and implementation fault tolerant model predictive control scheme on a simulated model of a three-tank hybrid system. CONFERENCE ON CONTROL AND FAULT-TOLERANT SYSTEMS, SYSTOL, 10 - FINAL PROGRAM AND BOOK OF ABSTRACTS, p. 173-178, 2010.. Proceedings... 2010.

REYES, J.; VELLASCO, M.; TANSCHEIT, R. Monitoramento e diagnóstico de múltiplos sensores por redes neurais auto-associativas.

Sba: CONTROLE \& AUTOMAÇÃO SOCIEDADE BRASILEIRA DE AUTOMÁTICA, v. 23, n. 2, p. 121-137, Apr. 2012. Proceedings... 2012.

ROSEMOUNT. The Engineer's Guide to Level Measurement.

2013. 314 p. Disponível em: <http://mydigimag.rrd.com/publication$/ ? \mathrm{i}=182123 \backslash$ \&elqaid $=1044 \backslash$ \&elqat $=2 \backslash$ \&elqTrackId=8582c7202bbd4e2d8603fa222a9a8ba1 $>$. Acesso em: 10 Jan. 2014.

Manual do radar Rosemount modelo 5400. 2014. 296 p. Disponível em: <http://www2.emersonprocess.com/siteadmincenter/pm rosemount documents/008090100-4026.pdf>. Acesso em: 12 Mar. 2014.

SACHDEVA, J. et al. A package SFERCB - Segmentation, feature extraction, reduction and classification analysis by both SVM and ANN for brain tumors. Applied Soft Computing, n. 47, p. 151-167, 2016.

SAMUEL, A. L. Some studies in machine learning using the game of checkers. IBM Journal of Research and Development, n. 49, p. 210-229, 1959.

SARTORI, J. C. Linhas de transmissão e carta de Smith: projeto assistido por computador. 1. ed. São Carlos: EESC USP, 1999.

SEN, S. K. et al. Support vector machine for data on manifolds: An application to image analysis. ISBI, 2008. Disponível em: <midag.cs.unc.edu/pubs/papers/isbi_SVMonManifoldData_v3-1.pdf>. Acesso em: 10 Mar. 2014.

SILVA, I. N.; SPATTI, D. H.; FLAUZINO, R. A. Redes neurais artificiais para engenharia e ciências aplicadas - curso prático. Artliber editora, 2010. 
SIMON, L. L.; HUNGERBUHLER, K. Industrial batch dryer data mining using intelligent pattern classifiers: Neural network, neuro-fuzzy and Takagi-Sugeno fuzzy models. Chemical engineering journal, v. 157, n. 2-3, p. 568-578, 2010.

SOUZAT, A. N. D.; HOSSRIT, R. M. C.; HOSSRIT, J. H. C. Intelligent system applied in diagnosis of transformer oil. DIELECTRIC MATERIALS, MEASUREMENTS AND APPLICATIONS CONFERENCE PUBLICATION, p. 330-334, 2000. Proceedings... 2000.

SUNA, R.; BERNS, K. Neuropipe neural network-based automatic pipeline inspection system. SPIE, v. 2911, p. 24-33, 1996.

TERZIC, E.; NAGARAJAH, R.; ALAMGIR, M. A neural network approach to fluid quantity measurement in dynamic environments. Mechatronics. Elsevier Ltd, v. 21, n. 1, p. 145-155, 2011.

TONG, S.; KOLLER, D. Support Vector Machine Active Learning with Applications to Text Classification. INTERNATIONAL CONFERENCE ON MACHINE LEARNING (ICML), 17, pages 287-295, Stanford, California, Jun. 1998. Proceedings... 1998.

TSOCHANTARIDIS THOMAS HOFMANN, T. J. I.; ALTUN, Y. Support vector machine learning for interdependent and structured output spaces. INTERNATIONAL CONFERENCE ON MACHINE LEARNING, 21. Banff, Canada, 2004.

Proceedings.... 2004. Disponível em: <www.cs.cornell.edu/People/tj/publications/tsochantaridis_etal_04a.pdf $>$.

TURING, A. M. Computing machinery and Intelligence. Mind, 1950. n. 49, p. 433-460.

UPADHYAYA, B.; MATHAI, G.; ERYUREK, E. Development and application of neural network algorithms for process diagnostics. IEEE CONFERENCE ON DECISION AND CONTROL, 29. Dec., 1990. p. 3277-3282. Proceedings... 1990.

VAPNIK, V. Statistical Learning Theory. Wiley, 1998.

VISHWANATHAN, S.; MURTY, M. N. SSVM: A simple SVM algorithm. 2002.

Disponível em: <www.stat.purdue.edu/ ${ }^{\sim}$ vishy/papers/VisMur02b.pdf >. Acesso em: 18 Mar. 2014.

WITTEN, I. W. The WEKA Data Mining Software. Disponível em: http://www.cs.waikato.ac.nz/ml/weka/. Acesso em: 12 Mar. 2014.

XU, H.; CARAMANIS, C.; MANNOR, S. Robustness and regularization of support vector machines. Journal of machine learning research, 10, p. 1485-1510. 2009.

ZHANG, H.; LIN, G. Remote intelligent monitoring system based on CAN fieldbus. INTERNATIONAL CONFERENCE ON ELECTRONICS, COMMUNICATIONS AND CONTROL, ICECC, 17, p. 384-387, 2011. Proceedings... 2011. 
Apêndices 


\section{APÊNDICE}

\section{Software de dimensionamento de instrumentos}

Esse apêndice apresenta uma visão geral do software TOOLKIT da Emerson Process Management direcionada à um dimensionamento de medidores de nível tipo radar.

O toolkit é um software gratuito que pode ser baixado pelo site abaixo:

http://www2.emersonprocess.com/pt-br/brands/rosemount/accessories/toolkit/pages /index.aspx

Esse software pode ser utilizado para:

- Registrar informações de aplicação e condições do processo;

- Executar cálculos necessários para a seleção de instrumentos;

- Criar e imprimir relatórios.

São possíveis os dimensionamentos das linhas de produtos para a medição de:

Pressão:

- Transmissores de Pressão;

- Selos Remotos com Transmissor;

- Transmissor de Painel para Óleo e Gás (linhas específicas para alguns tipos de indústria);

Nível:

- Selos Remotos com Transmissor;

- Transmissor de Nível por Radar;

- Transmissor Ultrassônico;

- Chave de Nível;

Vazão:

- Medidores de vazão por princípio de pressão diferencial;

- Medidores de vazão tipo Vortex;

- Medidor de Vazão Magnéticos;

- Medidor de Vazão Coriolis;

Temperatura: 
- Transmissores de Temperatura;

- Sensores de temperatura;

- Poços Termométricos.

\section{Exemplo de dimensionamento de um radar pelo toolkit:}

Após abrir o software e selecionar Level (nível) no menu à esquerda, pode se escolher o tipo de instrumento entre os indicados para medição de nível. Entre os instrumentos disponíveis estão os transmissores de pressão, transmissores de pressão com selos remotos, radares, ultrassônicos e as chaves de nivel como ilustrado na Figura 51.

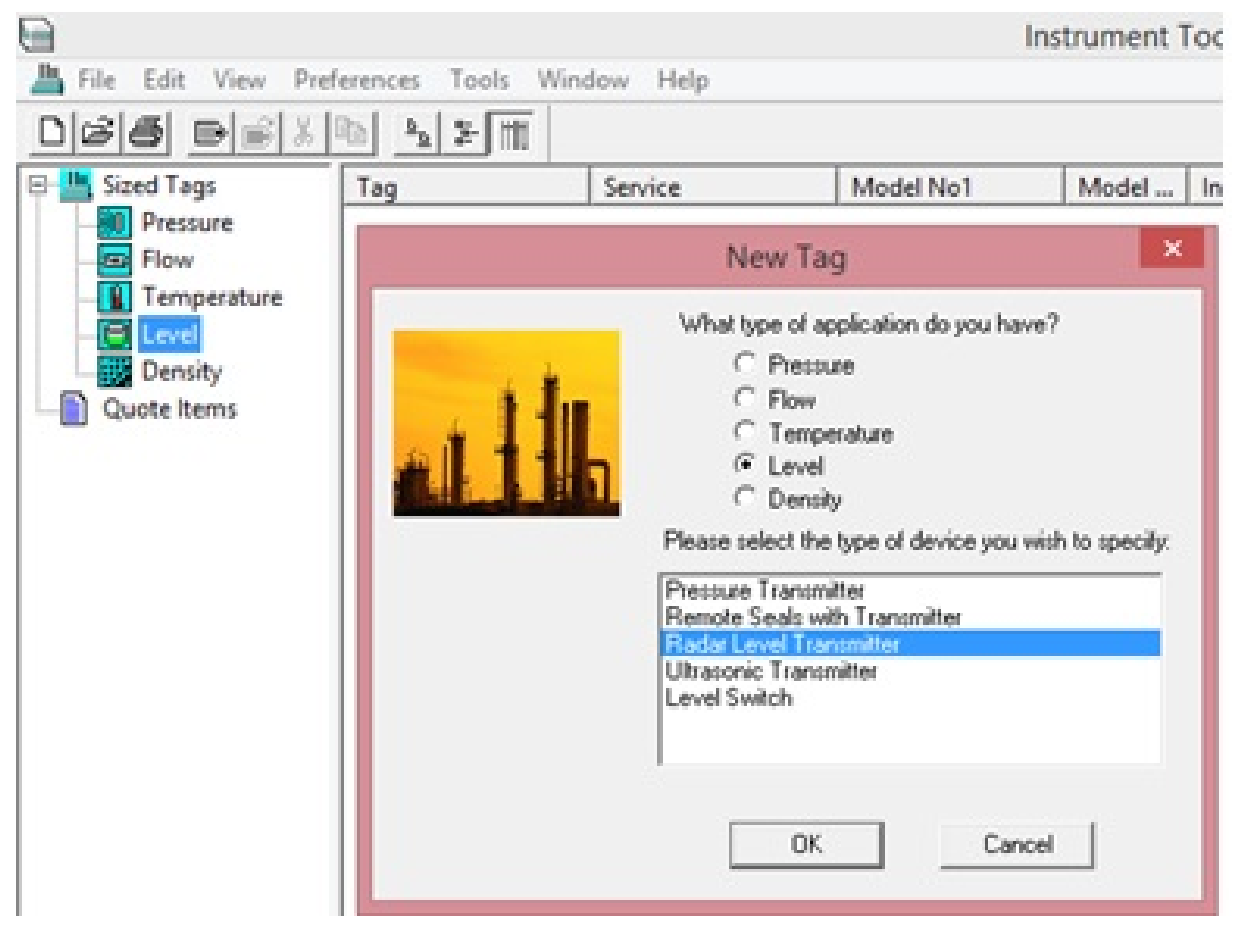

Figura 51 - Escolha da variável e do tipo de medidor.

Na tela seguinte, Figura 52, são solicitadas informações sobre o tag do medidor, normalmente seguindo-se os padrões de nomenclatura da ISA - Instrument Society Of America, a família do radar como os radares 5301 ou 5302 com onda guiada, ou os radares 5401 ou 5402 para aplicações sem o guia de onda. Além disso, são adicionados os valores mínimos e máximos de pressão e de temperatura e o tipo de fluido.

Ao se clicar em avançar, a página a seguir, Figura 53, solicita informações sobre as condições da superfície do liquido a ser medido, se há formação de espuma, vapores ou variações rápidas do nível. A informação do nome do fluido do processo é solicitada. A partir dessa informação, o software procura qual é a contante dielétrica associada à esse fluido em uma tabela interna. Se o fluido for desconhecido ou se for uma mistura de fluidos, o usuário deverá informar qual a constante dielétrica desse fluido.

Na próxima tela, Figura 54, informações sobre o formato do tanque, tipo do fundo do tanque, altura do tanque e da referência (altura em que o radar será instalado) são 


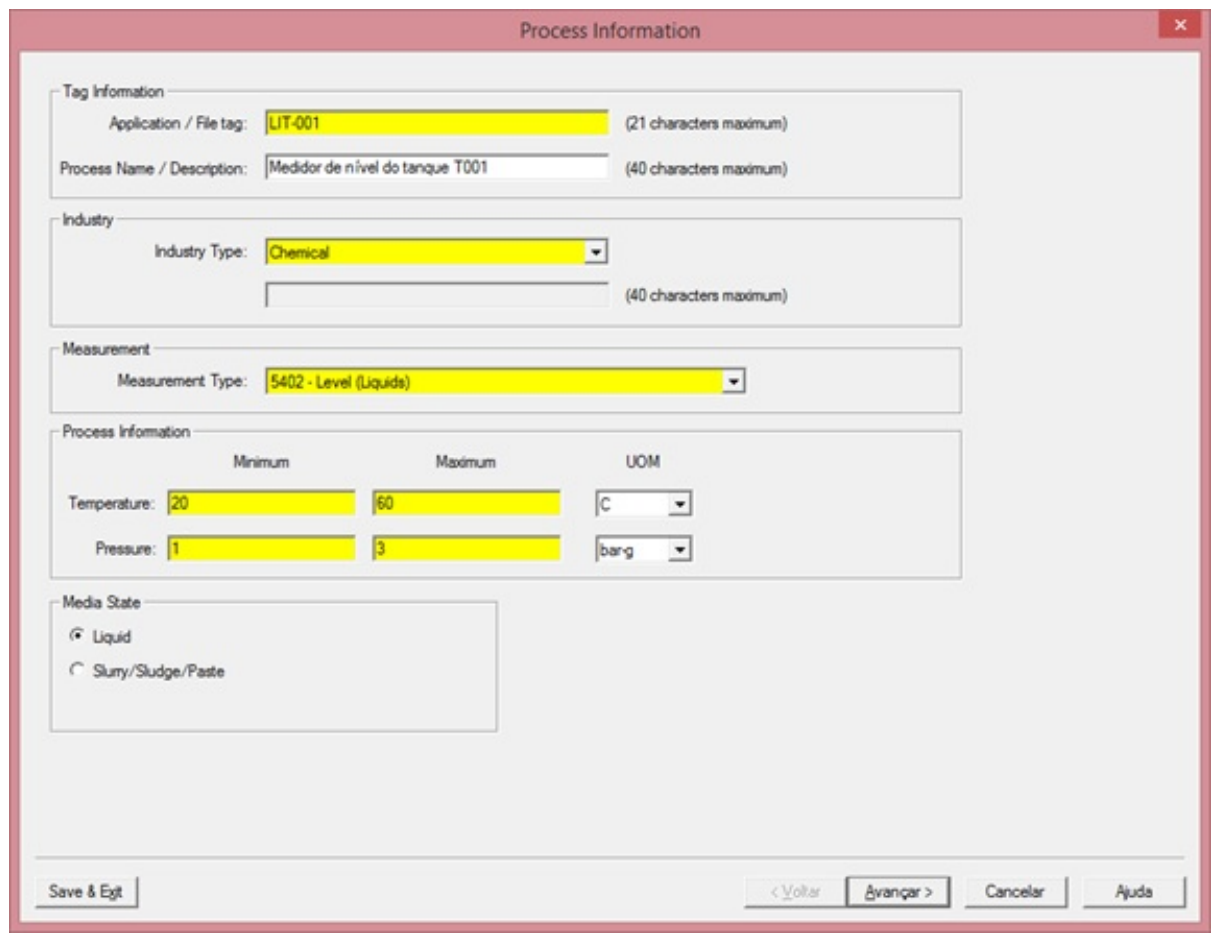

Figura 52 - Inserção do tag e dados do processo.

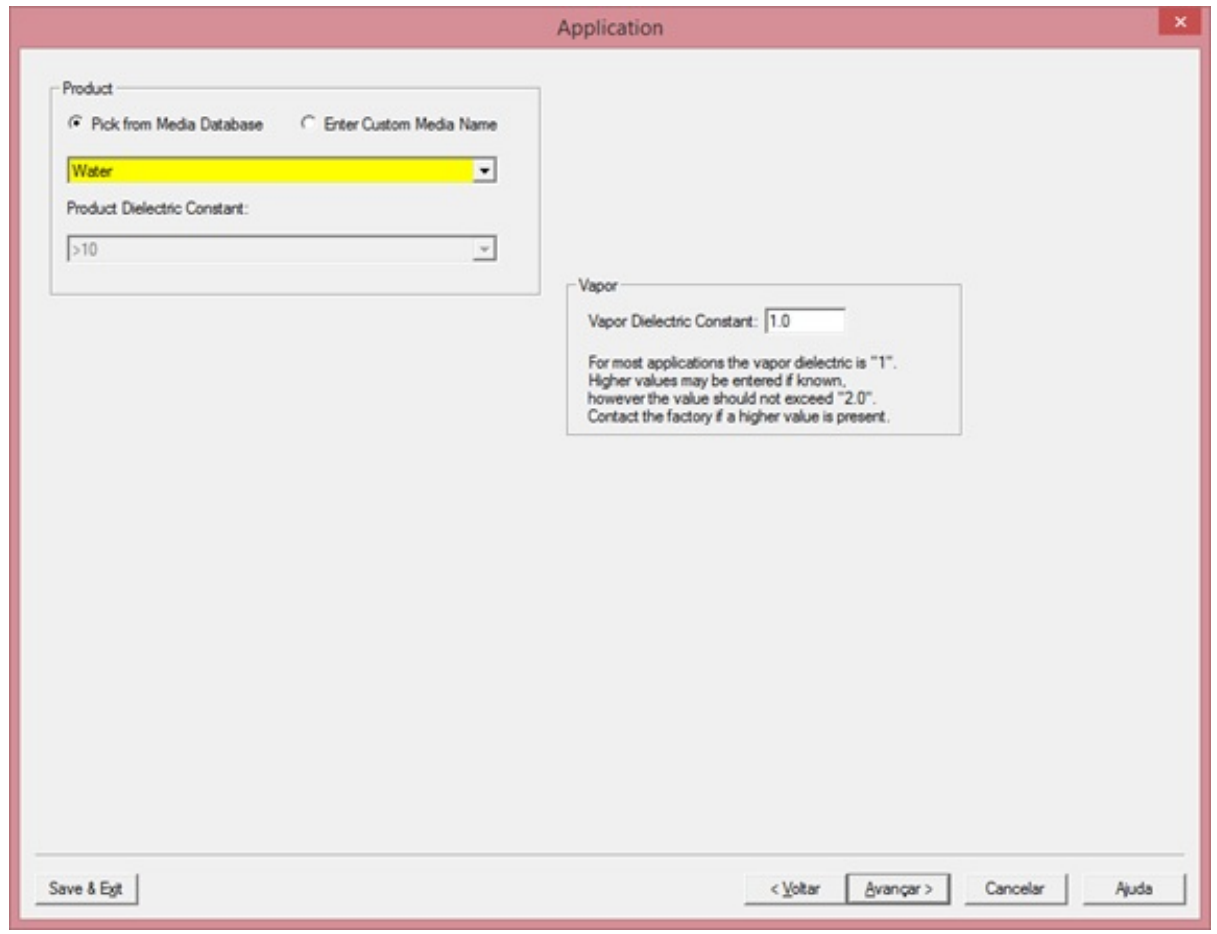

Figura 53 - Configuração do fluido e constante dielétrica.

pedidas.

Na próxima tela, Figura 55, os valores sobre a conexão do radar ao tanque são solicitados. 


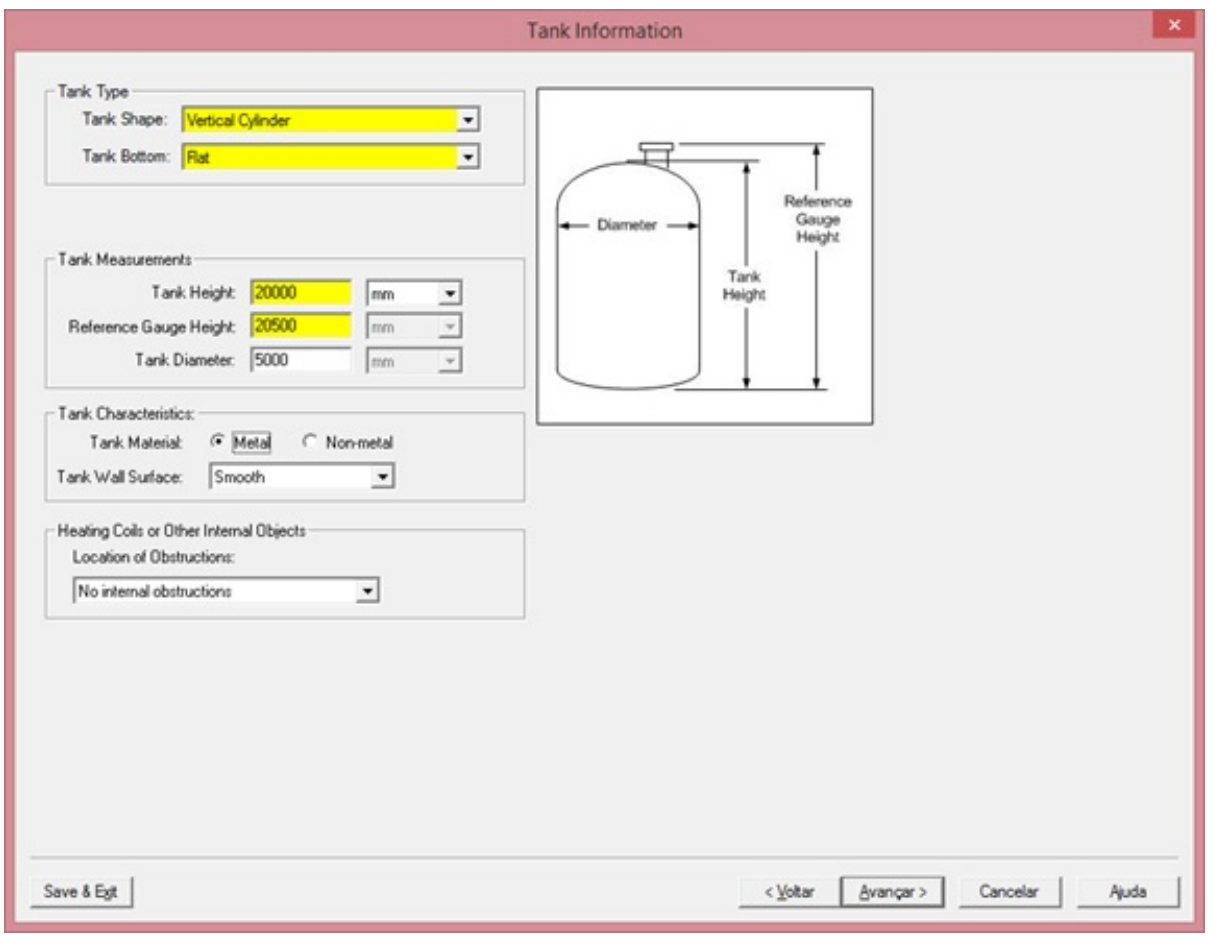

Figura 54 - Configuração da geometria do tanque

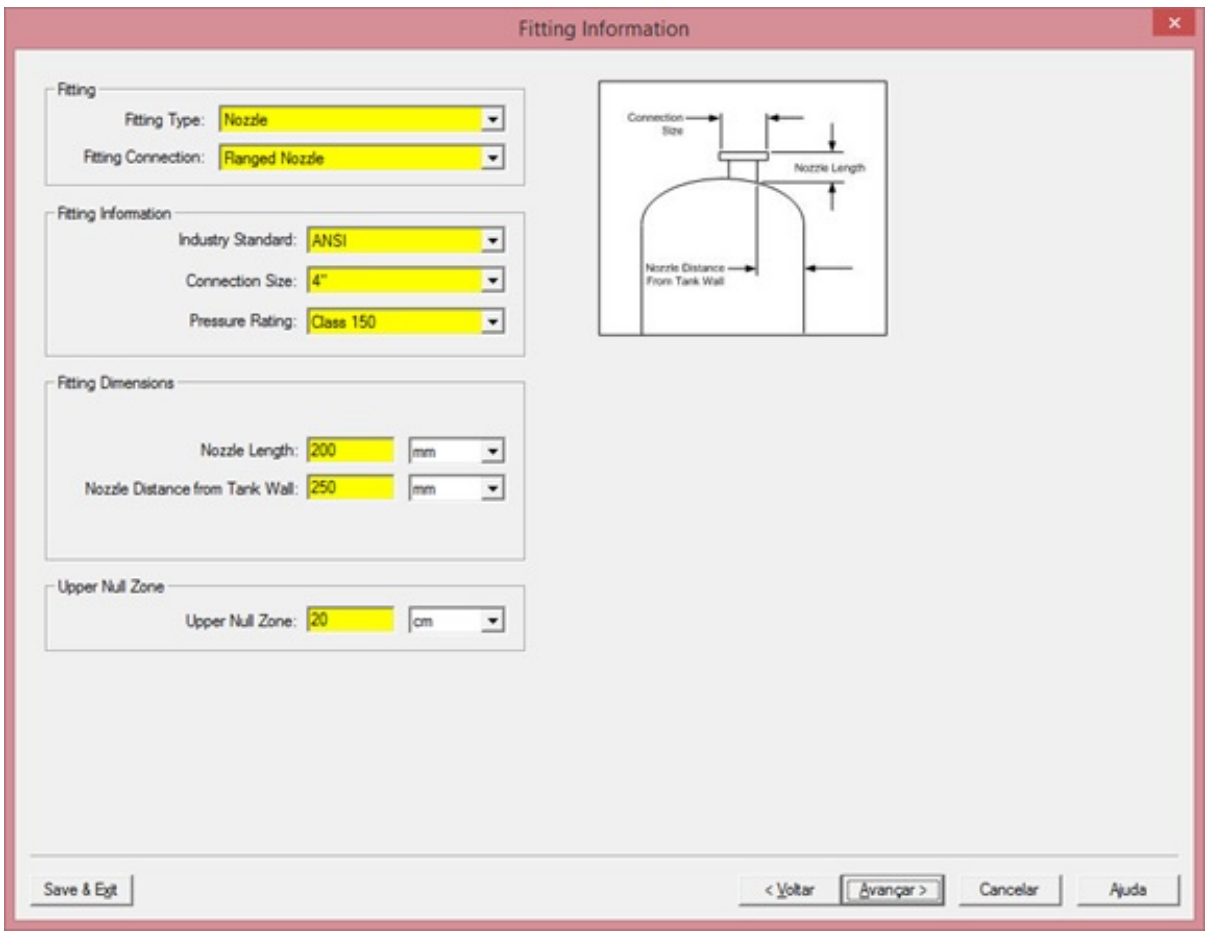

Figura 55 - Configuração dos detalhes da montagem.

A Figura 56 solicita os valores mínimo e máximo da variável que o radar entregará (variável de saída) são solicitados.

A importância da próxima tela, Figura 57, é mostrar graficamente uma estimativa de 


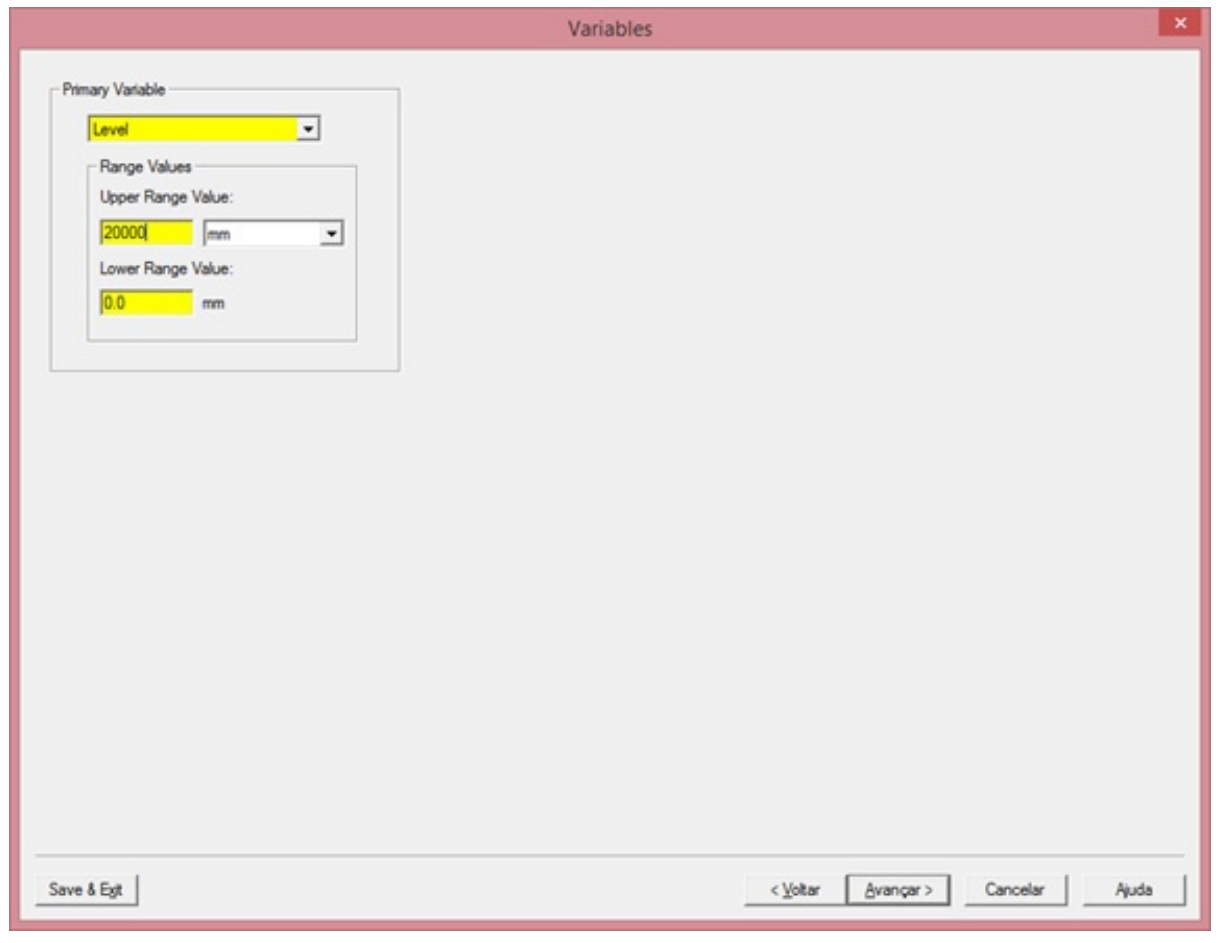

Figura 56 - Configuração da altura do flange do radar.

qual será o alcance máximo de medição de nível do radar baseado na constante dielétrica informada, nas condições de agitação, vapores e formação de espuma aplicadas aos diferentes tamanhos de antenas disponíveis.

Nas telas seguintes ilustradas como Figura 58, Figura 59 e Figura 60, as selecões realizadas permitem a escolha das opções que formarão o modelo completo do transmissor. Entre essas informações estão o tamanho da antena, o material do invólucro, o protocolo de comunicação, se o instrumento terá mostrador, quais as certificações (exemplo, certificado intrinsecamente seguro ou à prova de explosão, certificado de origem de material, certificado de calibração, etc).

Depois de se concluir a montagem do modelo do radar, é possível imprimir em formato de planilha excel, os dados de configuração do radar e a folha de especificação.

Ao final ficam registrados no software os dados de configuração e as opções do modelo do medidor montado que já está pronto para ser enviado à fábrica para se efetuar a importação do mesmo. 


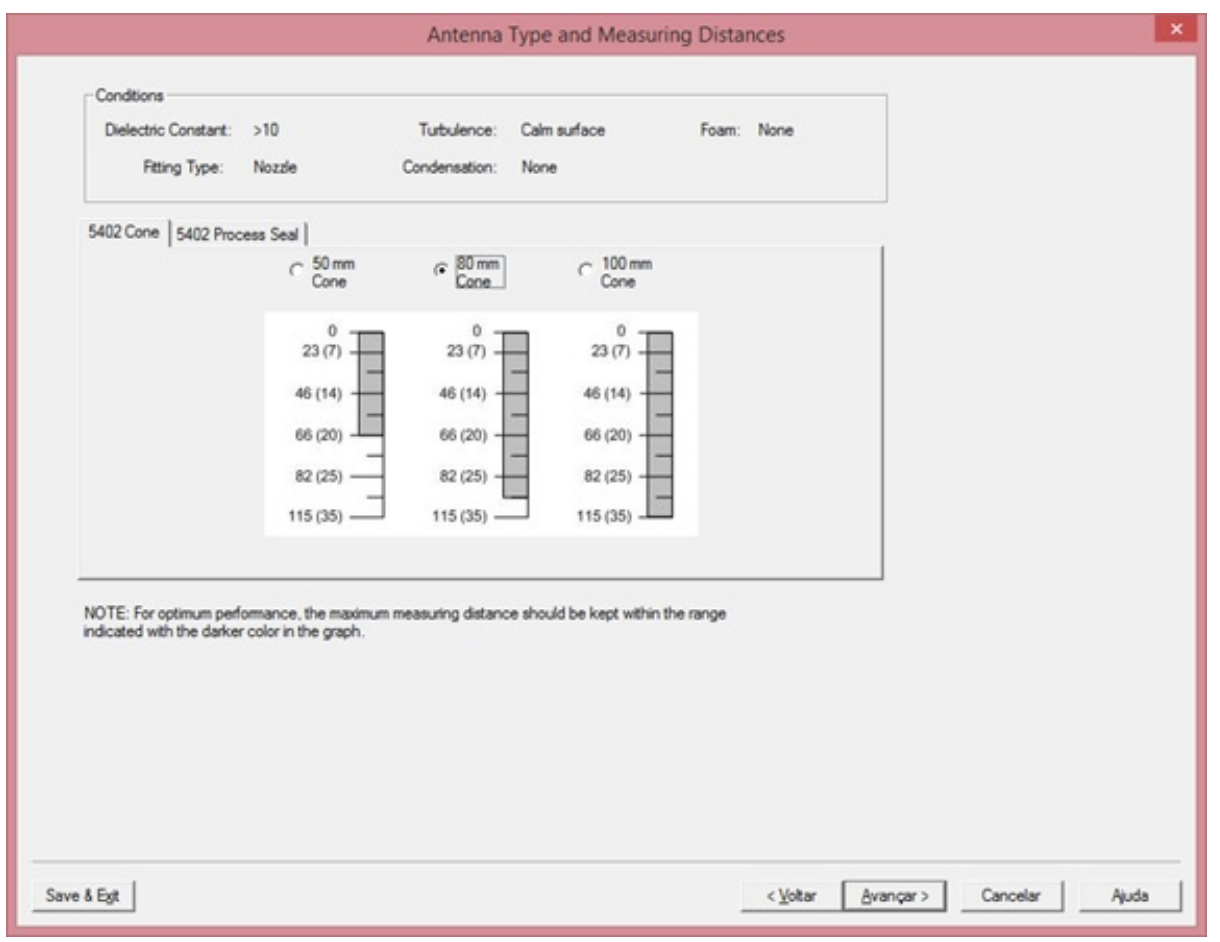

Figura 57 - Análise da altura medida dependendo do tamanho da antena e da constante dielétrica do fluido do processo.

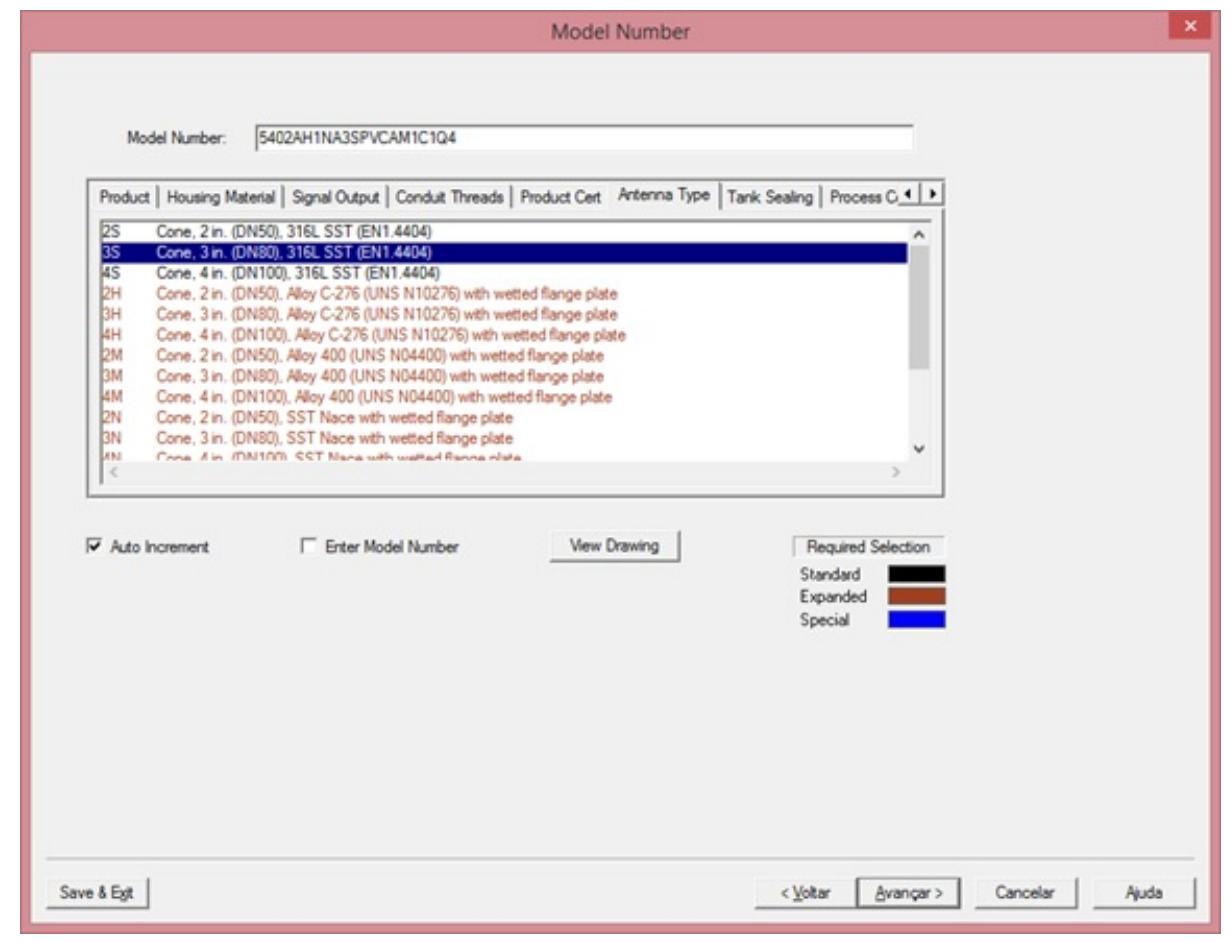

Figura 58 - Configuração da antena do radar 


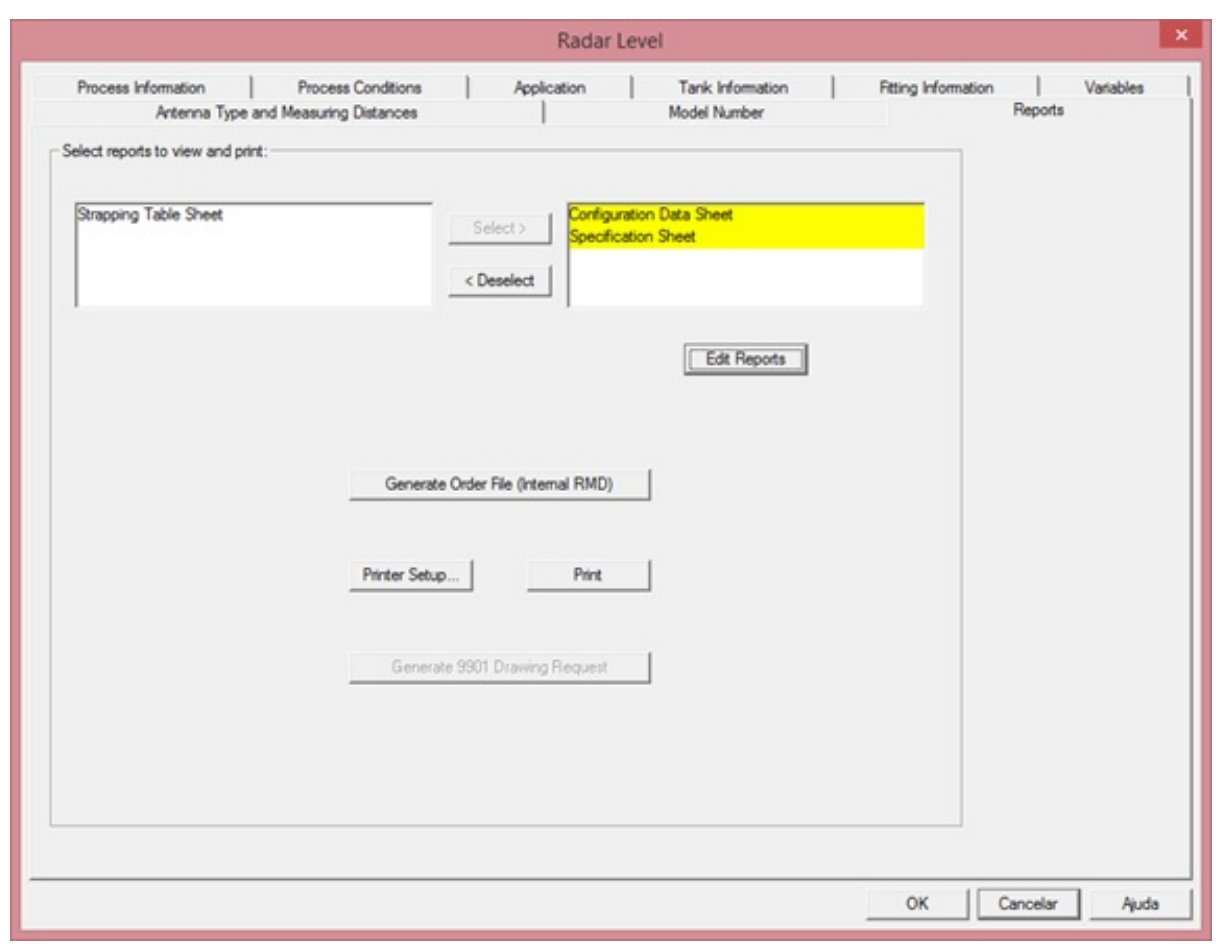

Figura 59 - Escolha do relatório para visualização ou impressão.

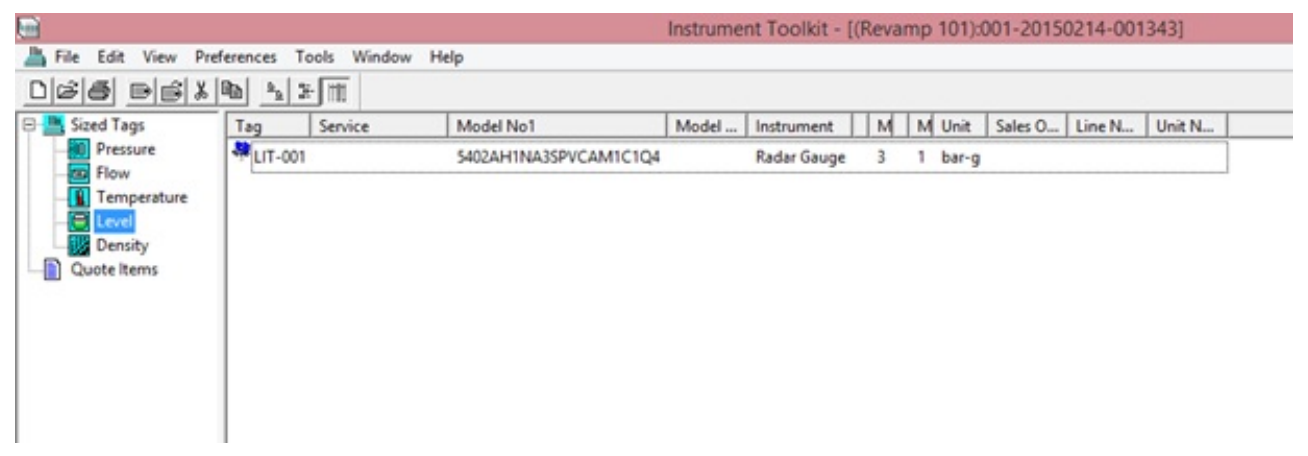

Figura 60 - Modelo completo e validado pelo toolkit. 


\section{APÊNDICE $\mathbf{B}$}

\section{Guia de seleção de modelo do radar e antena}

A Tabela 41 informa sobre algumas diretrizes da seleção dos modelos do radar e da antena dependendo das condições do processo. Nas colunas estão representados os radares modelo 5402 e o 5401. 
Tabela 41 - Guia de modelo e antena. Fonte: Baseado em Rosemount (2014).

Guia de modelo e antena

Essa tabela informa sobre algumas diretrizes da seleção dos modelos do radar e da antena dependendo das condições do processo.

G: bom; AD: dependente da aplicação; NR: não recomendado.

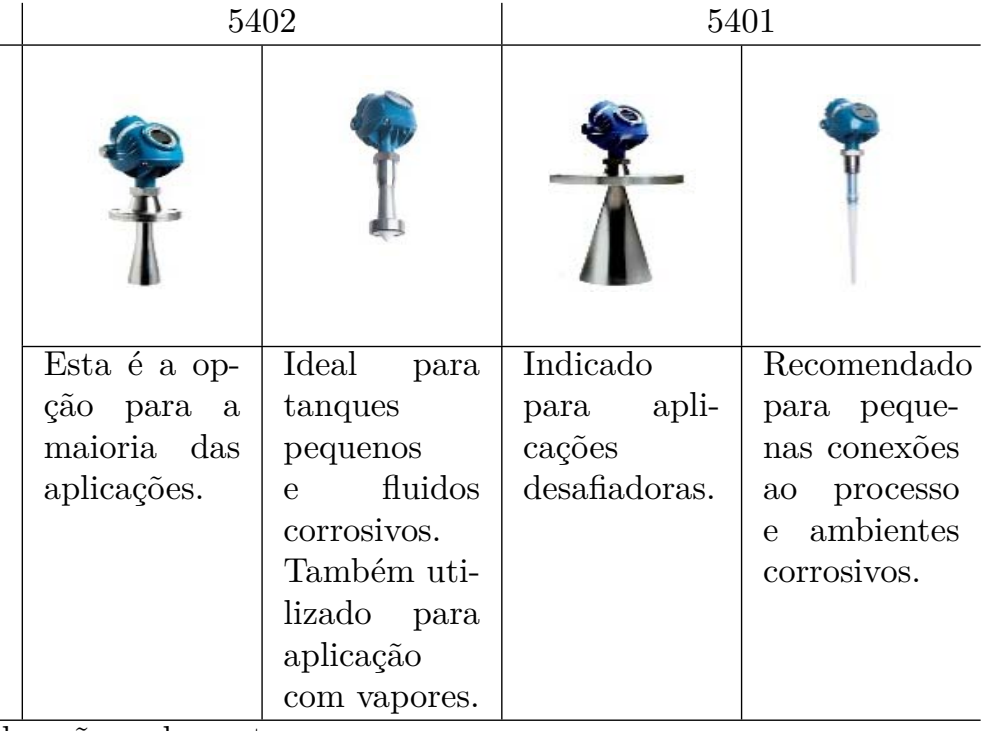

Considerações sobre o tanque.

\begin{tabular}{|c|c|c|c|c|}
\hline Instalação próxima da parede lisa do tanque. & $\mathrm{G}$ & G & $\mathrm{G}$ & $\mathrm{G}$ \\
\hline Multiplas unidades no mesmo tanque. & G & G & G & G \\
\hline $\begin{array}{c}\text { Obstruções internas (no caminho da } \\
\text { micro-onda) }\end{array}$ & NR & NR & $\mathrm{AD}$ & $\mathrm{AD}$ \\
\hline $\begin{array}{c}\text { Obstruções internas (fora do caminho da } \\
\text { micro-onda) }\end{array}$ & $\mathrm{G}$ & G & $\mathrm{NR}$ & NR \\
\hline Ângulo do beam. & $\begin{array}{c}2^{\prime \prime} 19^{\mathrm{o}} \\
3^{\prime \prime} 14^{\mathrm{O}} \\
4^{\prime \prime} 9^{\mathrm{o}}\end{array}$ & $\begin{array}{c}2^{\prime \prime} 19^{\mathrm{o}} \\
3^{\prime \prime} 14^{\mathrm{o}} \\
4^{\prime \prime} 9^{\mathrm{o}}\end{array}$ & $\begin{array}{l}4^{\prime \prime} 37^{\mathrm{o}} \\
6^{\prime \prime} 23^{\mathrm{o}} \\
8^{\prime \prime} 17^{\mathrm{O}}\end{array}$ & $37^{\circ}$ \\
\hline Antena se estende para baixo do bocal. & $\mathrm{G}$ & $\mathrm{G}$ & $\mathrm{G}$ & G \\
\hline $\begin{array}{l}\text { Antena com recesso em bocal liso até } 6 \text { pés } \\
\qquad(2 \mathrm{~m})\end{array}$ & G & $\mathrm{G}$ & $\mathrm{AD}(2)$ & $\mathrm{NR}(3)$ \\
\hline $\begin{array}{c}\text { Antena com recesso em bocal com } \\
\text { irregularidades (como rebarbas de soldas). }\end{array}$ & $\mathrm{AD}(2)$ & $\mathrm{AD}$ & $\mathrm{AD}(2)$ & $\mathrm{NR}(3)$ \\
\hline Montagem em tubo acalmador. & G 2- 4"pipe & G 2-4"pipe & G 3- 8"pipe & NR \\
\hline Válvulas. & $\mathrm{G}$ & $\mathrm{G}$ & NR & NR \\
\hline Grandes alturas ( $>115$ polegadas $/ 35 \mathrm{~m}$ ). & NR & NR & NR & NR \\
\hline Facilidade de limpeza da antena. & $\mathrm{AD}$ & $\mathrm{G}$ & $\mathrm{AD}$ & G \\
\hline \multicolumn{5}{|c|}{ Características do ambiente do processo. } \\
\hline Vapor (pouco, médio). & $\mathrm{G}$ & $\mathrm{G}$ & G & G \\
\hline Vapor (muito). & NR & $\mathrm{AD}$ & G & $\mathrm{G}$ \\
\hline Vapor condensante / produto que se aglutina. & $\mathrm{AD}$ & $\mathrm{G}$ & G & $\mathrm{AD}$ \\
\hline $\begin{array}{l}\text { Superfície borbulhante / turbulenta (pouco / } \\
\text { media) }\end{array}$ & G & G & G & $\mathrm{G}$ \\
\hline Superfície borbulhante / turbulenta (muito) & $\mathrm{AD}$ & $\mathrm{AD}$ & $\mathrm{G}(6)$ & NR \\
\hline $\begin{array}{c}\text { Superfície borbulhante / turbulenta (com } \\
\text { tubo acalmador) }\end{array}$ & $\mathrm{G}$ & $\mathrm{G}$ & $\mathrm{G}$ & NR \\
\hline Espuma. & NR & NR & $\mathrm{AD}$ & $\mathrm{AD}$ \\
\hline Espuma ( com tubo acalmador) & $\mathrm{G}$ & $\mathrm{G}$ & $\mathrm{G}$ & NR \\
\hline Produtos corrosivos. & $\mathrm{G}(8)$ & $\mathrm{G}(8)$ & $\mathrm{G}(8)$ & $\mathrm{G}$ \\
\hline Fluidos com dielétricos muito baixos. & $\mathrm{G}$ & $\mathrm{G}$ & $\mathrm{G}$ & $\mathrm{AD}$ \\
\hline $\begin{array}{l}\text { Alterações de densidade, dielétricos, pH, } \\
\text { pressão ou temperatura. }\end{array}$ & G & G & G & G \\
\hline Líquidos viscosos, aderentes ou cristalizantes. & G & G & $\mathrm{G}$ & G \\
\hline Sólidos, grãos, pós & $\mathrm{G}$ & NR & NR & NR \\
\hline
\end{tabular}




\section{Gráficos da distância, amplitude e velocidade em relação ao tempo}

Os gráficos a seguir se referem ao cenário preliminar apresentado nessa tese. A Figura 61 ilustra a distância pelo tempo.

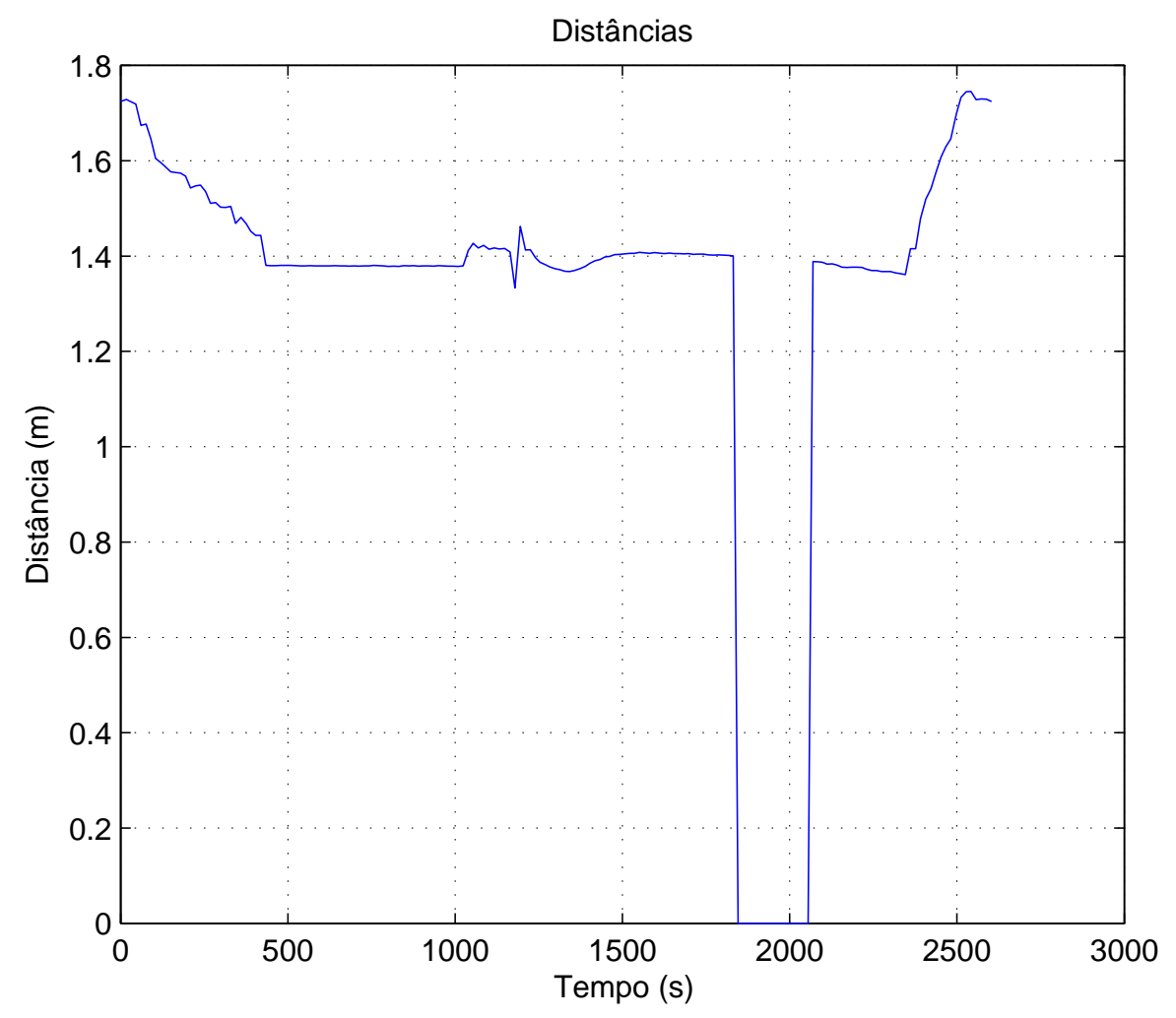

Figura 61 - Gráfico da distância pelo tempo.

Na Figura 62 é ilustrado o gráfico da amplitude do sinal.

Na Figura 63 é mostrado o gráfico da velocidade de variação da distância no tempo. 


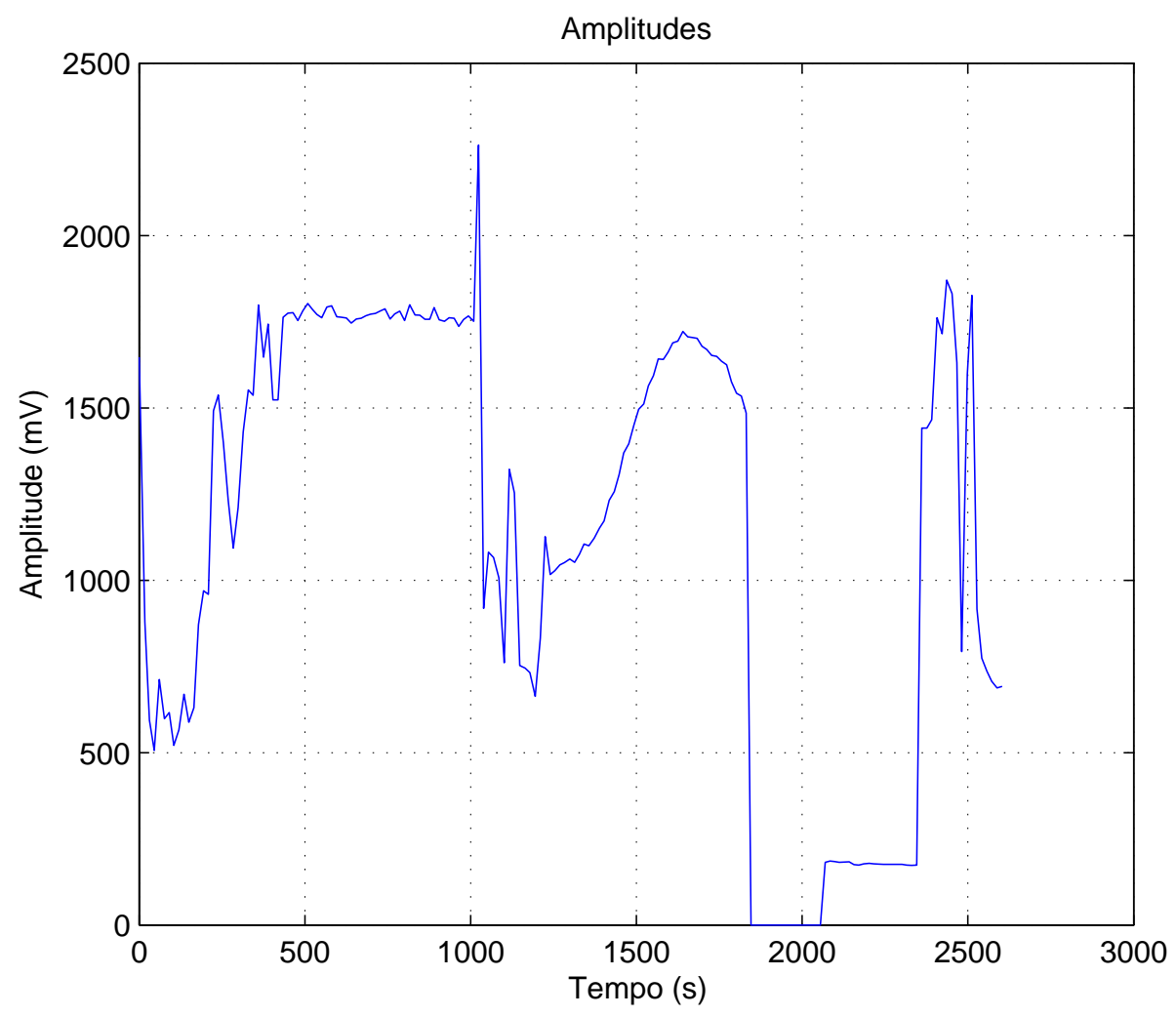

Figura 62 - Gráfico da amplitude pelo tempo.

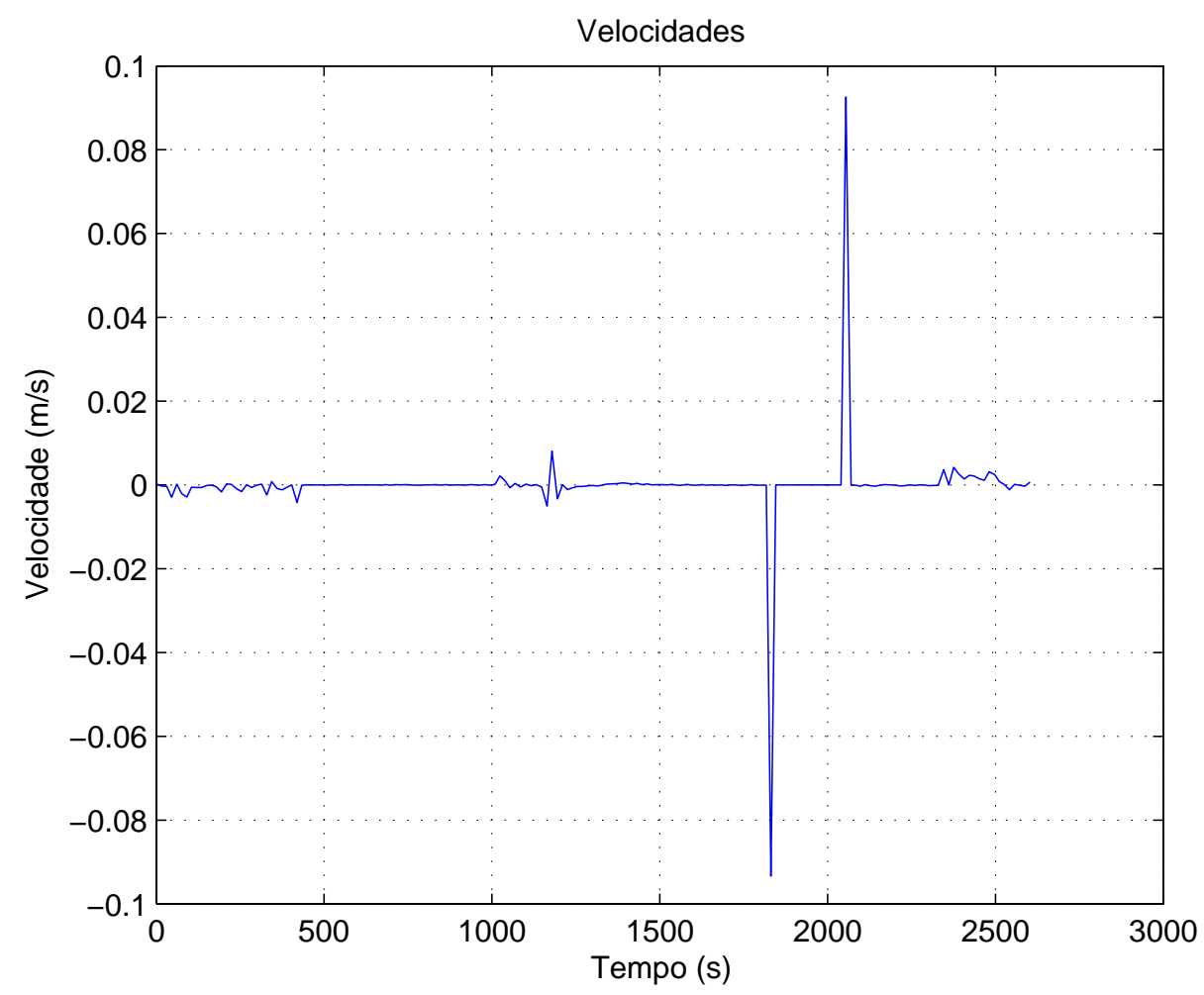

Figura 63 - Gráfico da velocidade pelo tempo. 


\section{Programação no Matlab (RNA) e no Weka (SVM)}

Esse apêndice mostra os códigos utilizados no Matlab para os procedimentos de recebimento das informações no ambiente Matlab, os janelamentos para aplicação dos tratamentos estatísticos e o treinamento da rede neural para o quarto cenário. As telas de configuração do software Weka para aplicação do classificador SVM tabém estão presentes.

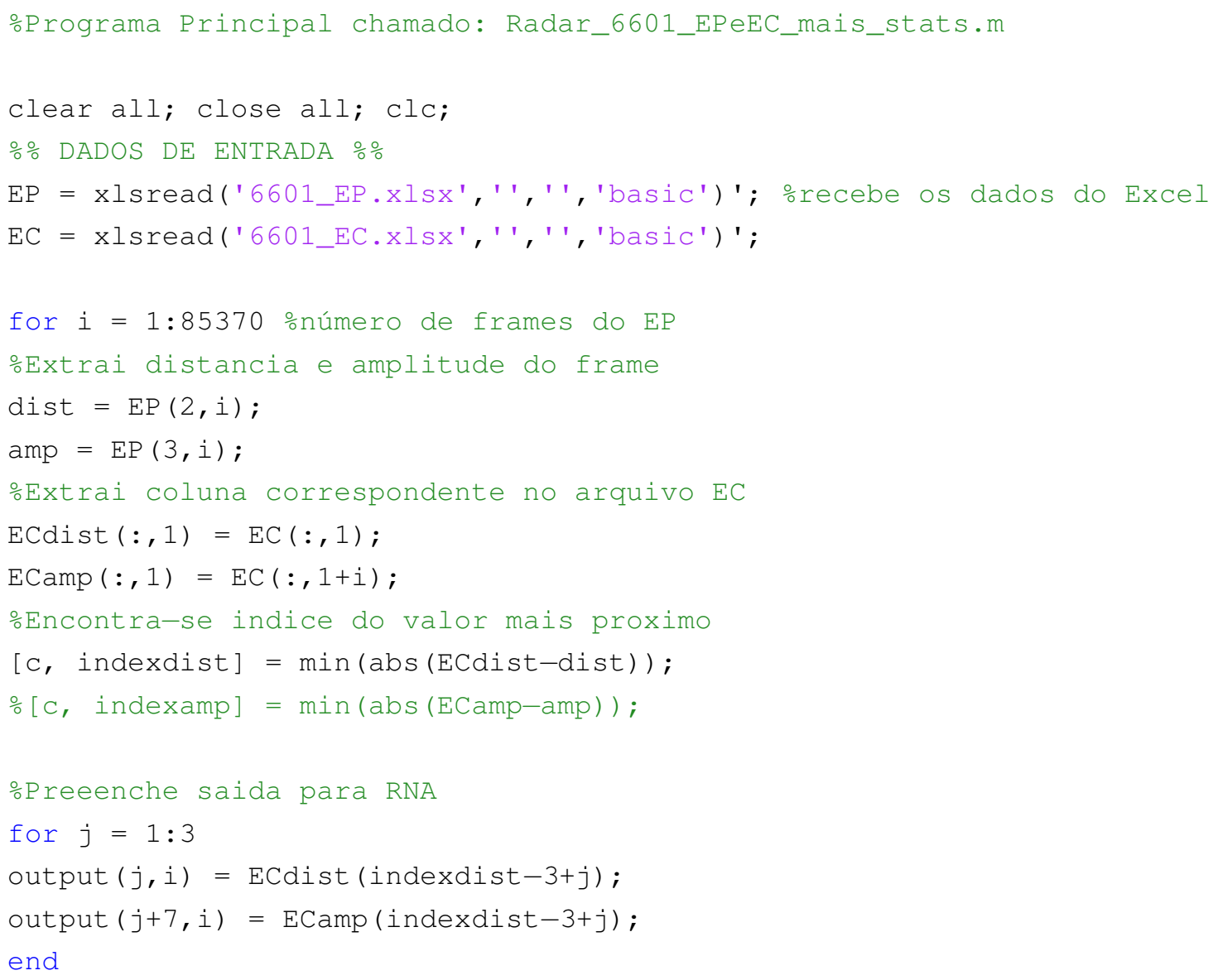




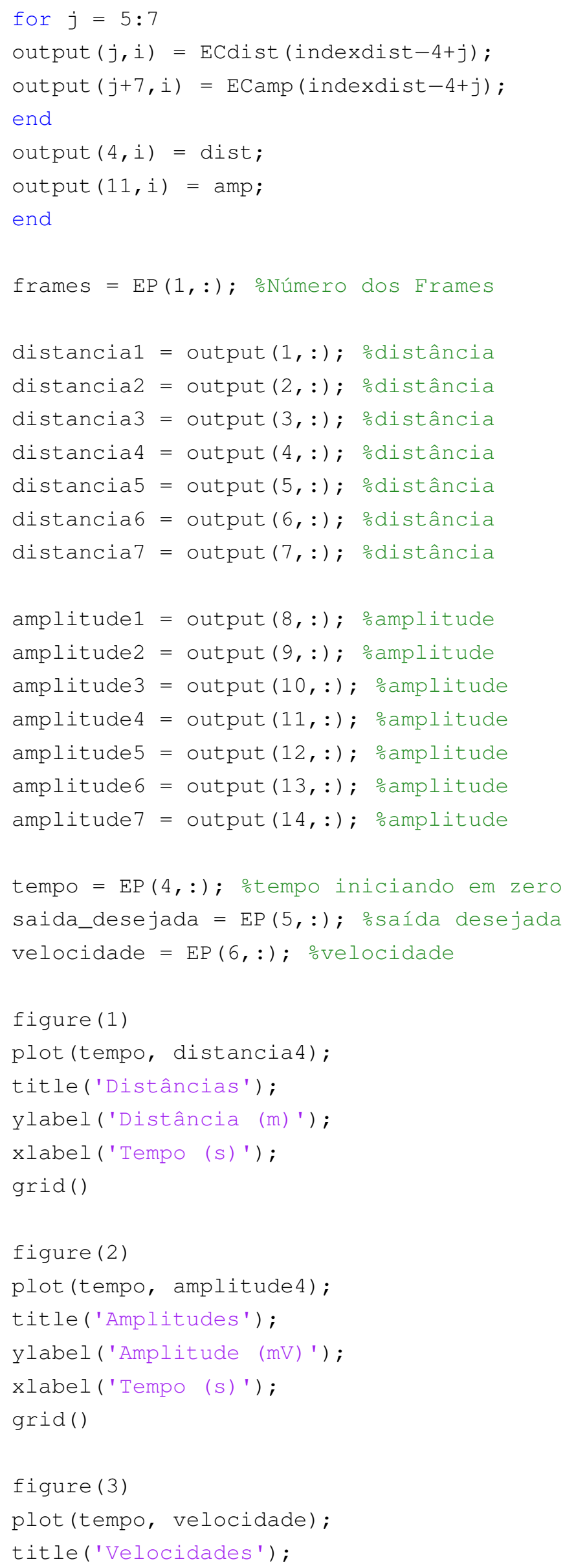




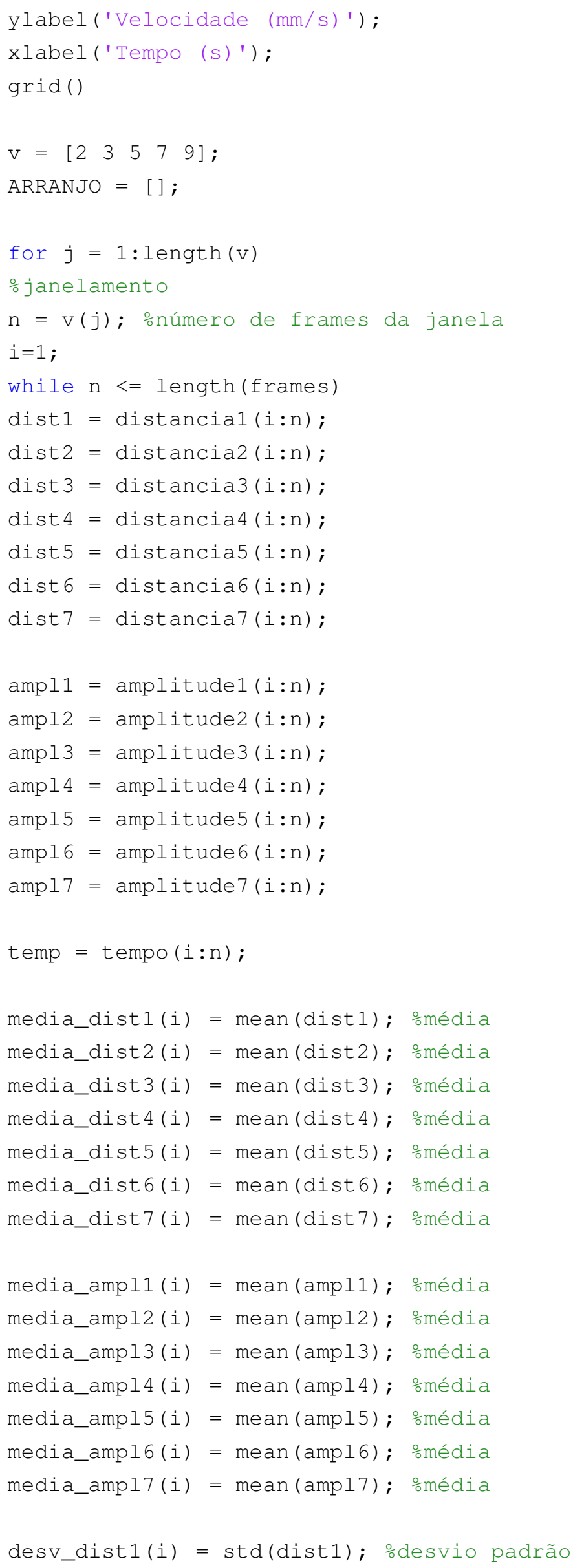




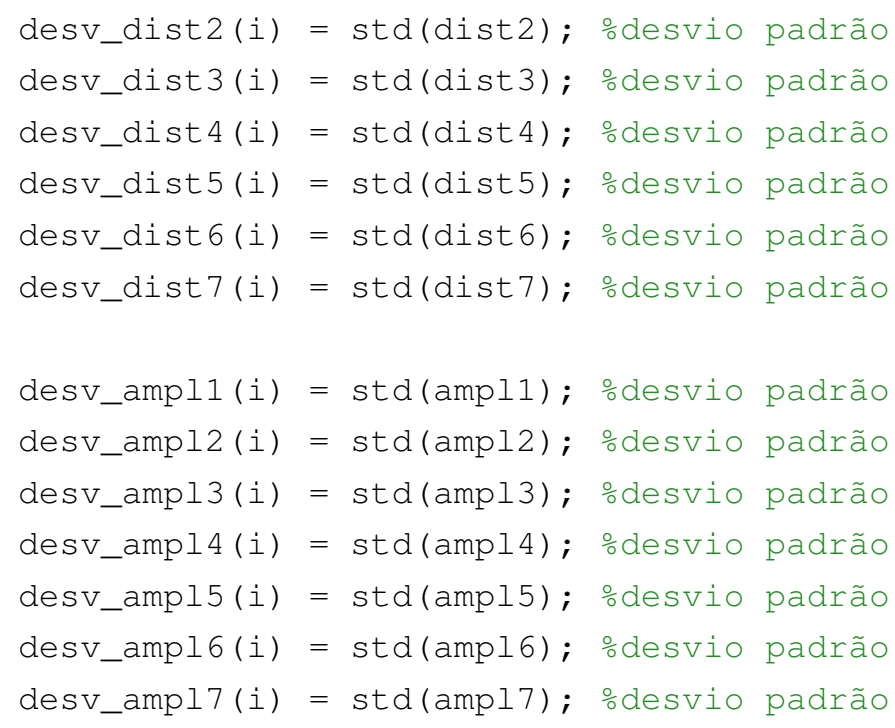




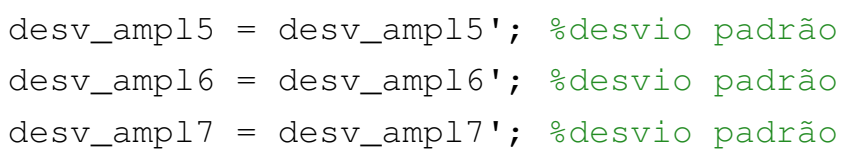




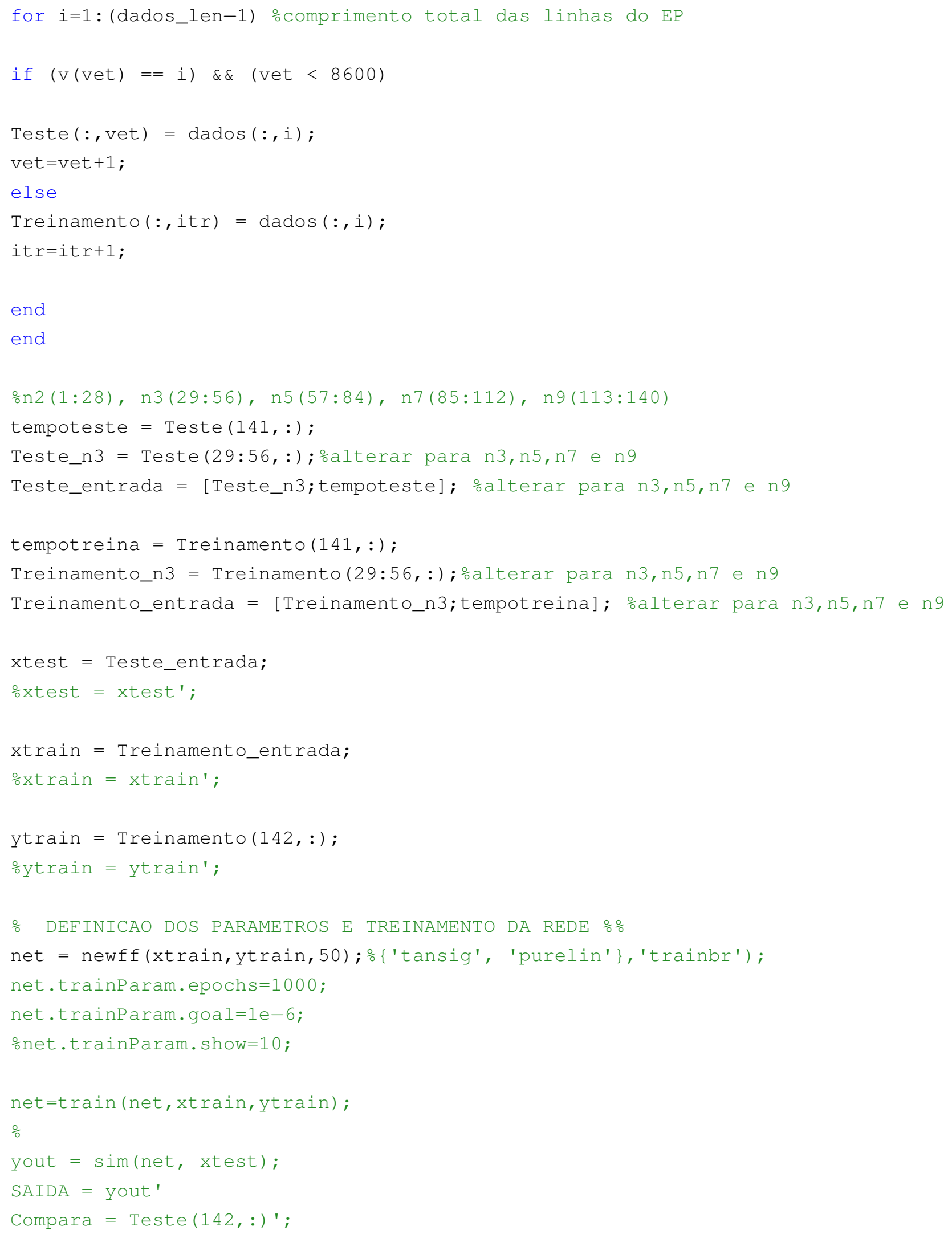


\% Esse programa foi utilizado para a geração das saídas desejadas (problema 1 \% e problema 2) Esse programa tem que ser rodado previamente ao principal.

clear all; close all; clc;

응 DADOS DE ENTRADA 응

$\mathrm{EP}=$ xlsread('6601_EP.xlsx',' ','','basic')'; orecebe os dados do Excel

\% EC = xlsread('289_japan_EC.xlsx',' ',' ',' 'basic')';

frames $=\operatorname{EP}(1,:) ;$ Número dos Frames

distancia $=\operatorname{EP}(2,:)$; odistância

amplitude $=\operatorname{EP}(3,:)$; $\frac{\circ}{\text { omplitude }}$

tempo $=\operatorname{EP}(4,:)$; otempo iniciando em zero

velocidade $=\operatorname{EP}(5,:) ;$ ovelocidade

$\mathrm{V}=\left[\begin{array}{lllll}2 & 3 & 5 & 7 & 9\end{array}\right] ;$

ARRANJO = [];

for $j=1$ : length $(\mathrm{v})$

\%janelamento

$\mathrm{n}=\mathrm{v}(j) ;$ onúmero de frames da janela

$i=1$;

while $\mathrm{n}<=$ length (frames)

dist $=$ distancia $(i: n)$;

ampl = amplitude (i:n);

temp $=$ tempo $(i: n)$;

media_dist $(i)=\operatorname{mean}($ dist $) ;$ omédia

media_ampl $(i)=\operatorname{mean}(\operatorname{ampl}) ;$ omédia

desv_dist(i) = std(dist); \%desvio padrão

desv_ampl(i) = std(ampl); \%desvio padrão

$i=i+1 ;$

$\mathrm{n}=\mathrm{n}+1$;

end

media_dist $=$ media_dist' $;$ omédia

media_ampl = media_ampl'; \%média

desv_dist $=$ desv_dist'; \%desvio padrão

desv_ampl = desv_ampl'; \%desvio padrão

ARRANJOn = [media_dist media_ampl desv_dist desv_ampl];

$\mathrm{x}=\operatorname{size}($ ARRANJOn);

$y=\operatorname{size}($ ARRANJO);

while $(x(1)<y(1))$

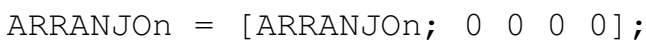




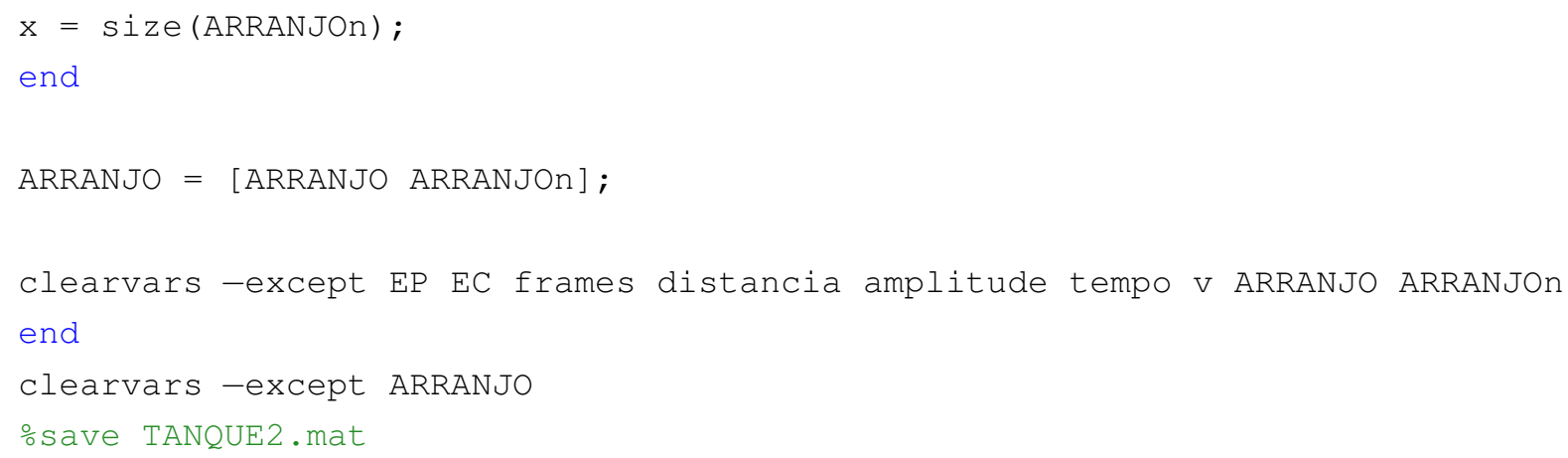




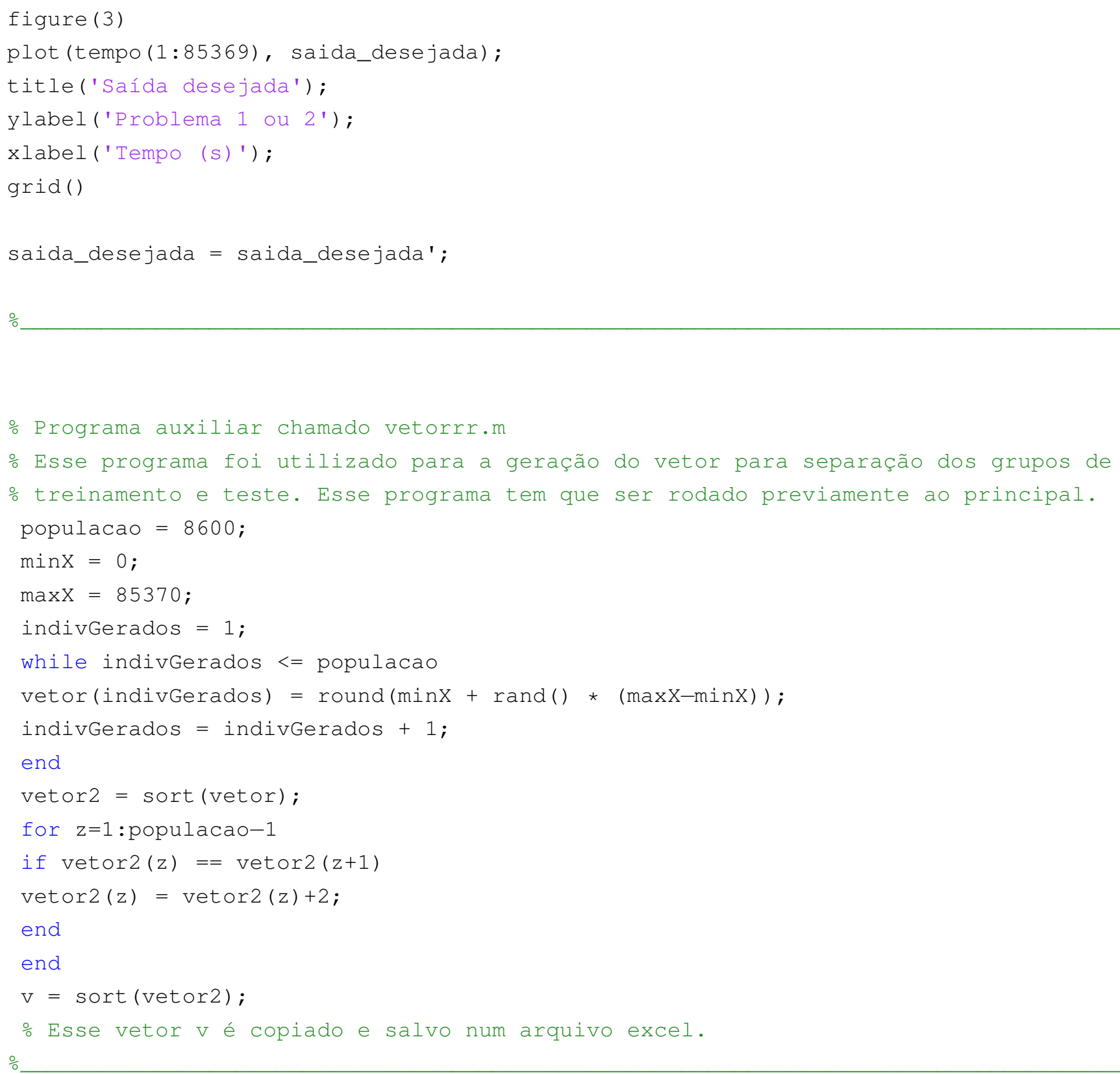

Os mesmos arquivos de treinamento e de testes das redes neurais foram utilizados para o SVM. Foram montados os arquivos .arff com seus cabeçalhos que informam as categorias (atributos) dos dados de entrada definidas como mostrado na Figura 64. Para as classificações do quarto cenário foram montados os arquivos: OG6601_treinamento_n2.arff, OG6601_teste_n2.arff, OG6601_treinamento_n3.arff, OG6601_teste_n3.arff, OG6601_treinamento_n5.arff, OG6601_teste_n5.arff, OG6601_treinamento_n7.arff, OG6601_teste_n7.arff, OG6601_treinamento_n9.arff, e OG6601_teste_n9.arff, onde n se refere ao número de elementos utilizados no janelamento dos dados para o tratamento estatístico.

Esses arquivos foram selecionados aos pares para informar o conjunto de treinamento/teste ao software Weka como ilustrado na Figura 65. O tipo do classificador e suas propriedades estão mostrados na Figura 66. 


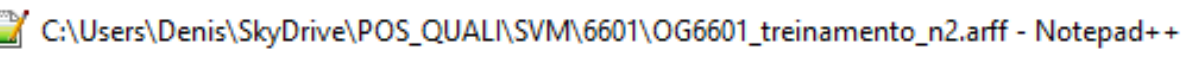

Arquivo Editar Localizar Visualizar Formatar Linguagem Configurações Macro Executar Plugins

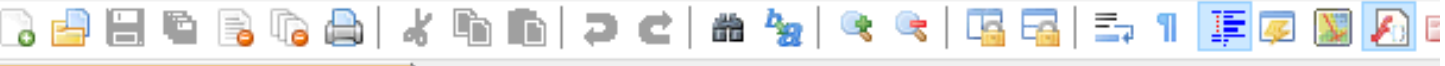
目OG6601_treinamento_n2.arf $\mathrm{X}$

1 @relation OG6601n2

2

3 Qattribute mediadist1 numeric

4 Qattribute mediadist2 numeric

5 dattribute mediadist 3 numeric

6 dattribute mediadist 4 numeric

7 Qattribute mediadist 5 numeric

8 dattribute mediadist 6 numeric

9 Qattribute mediadist 7 numeric

10 dattribute mediaampl1 numeric

11 eattribute mediaampl2 numeric

12 dattribute mediaampl3 numeric

13 @attribute mediaampl4 numeric

14 dattribute mediaampl5 numeric

15 dattribute mediaampl6 numeric

16 @attribute mediaampl7 numeric

17 eattribute desvpdrdist1 numeric

18 eattribute desvpdrdist2 numeric

19 dattribute desvpdrdist 3 numeric

20 eattribute desvpdrdist 4 numeric

21 Qattribute desvpdrdist5 numeric

22 dattribute desvpdrdist 6 numeric

23 @attribute desvpdrdist7 numeric

24 @attribute desvpdrampl1 numeric

25 eattribute desvpdrampl2 numeric

26 dattribute desvpdrampl3 numeric

27 eattribute desvpdrampl4 numeric

28 eattribute desvpdramp15 numeric

29 dattribute desvpdrampl6 numeric

30 eattribute desvpdrampl7 numeric

31 eattribute tempo numeric

32 eattribute problema \{SEMPROBL, HIVARAMPL, LOAMPL\}

33

34 @data

$\begin{array}{llllll}35 & 1.15929 & 1.18395 & 1.20862 & 1.20819 & 1.23328\end{array}$

Figura 64 - Estrutura do cabeçalho do arquivo ".arff". 
2 Weka Explorer

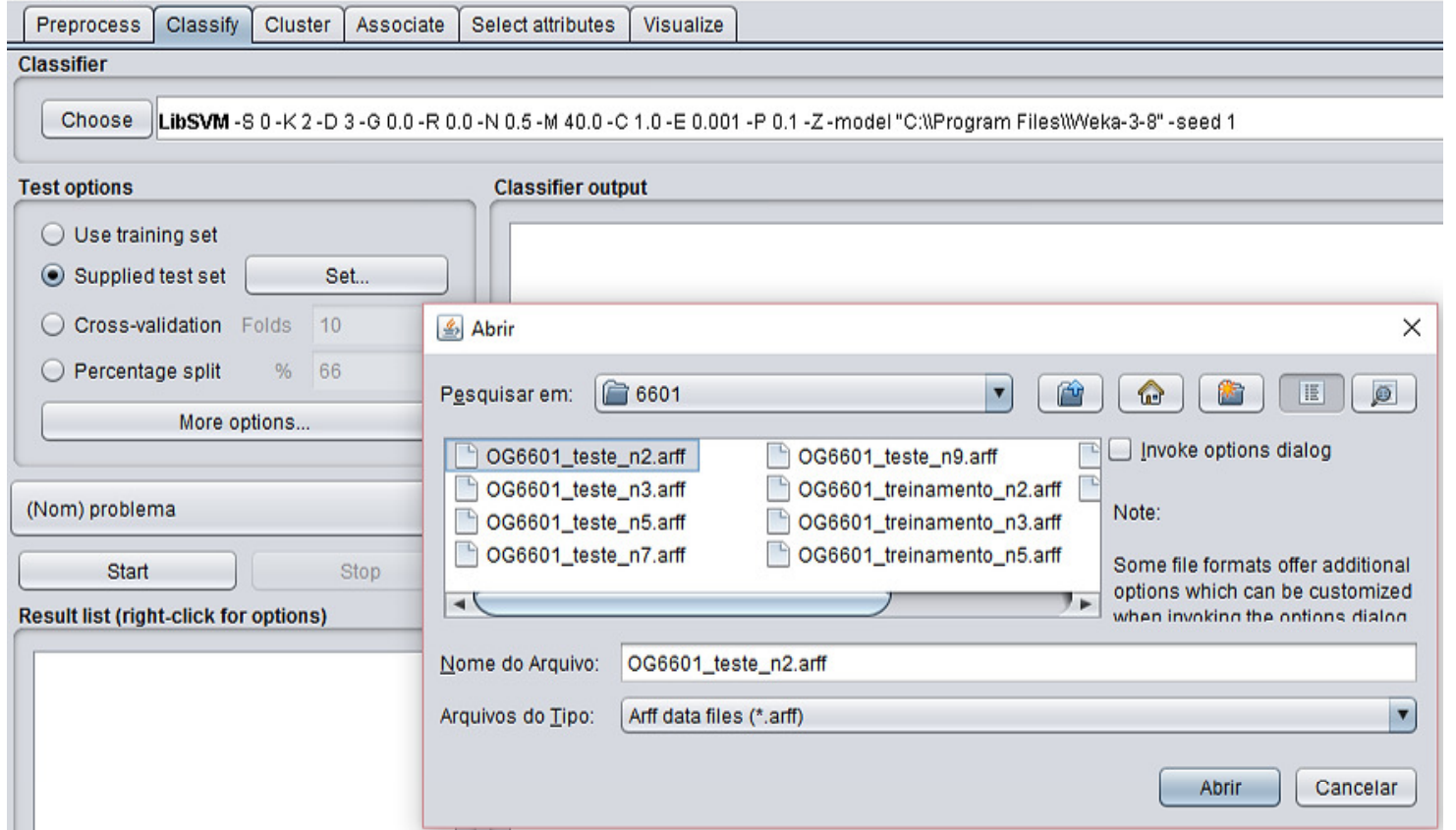

Figura 65 - Seleção do arquivo de teste. 


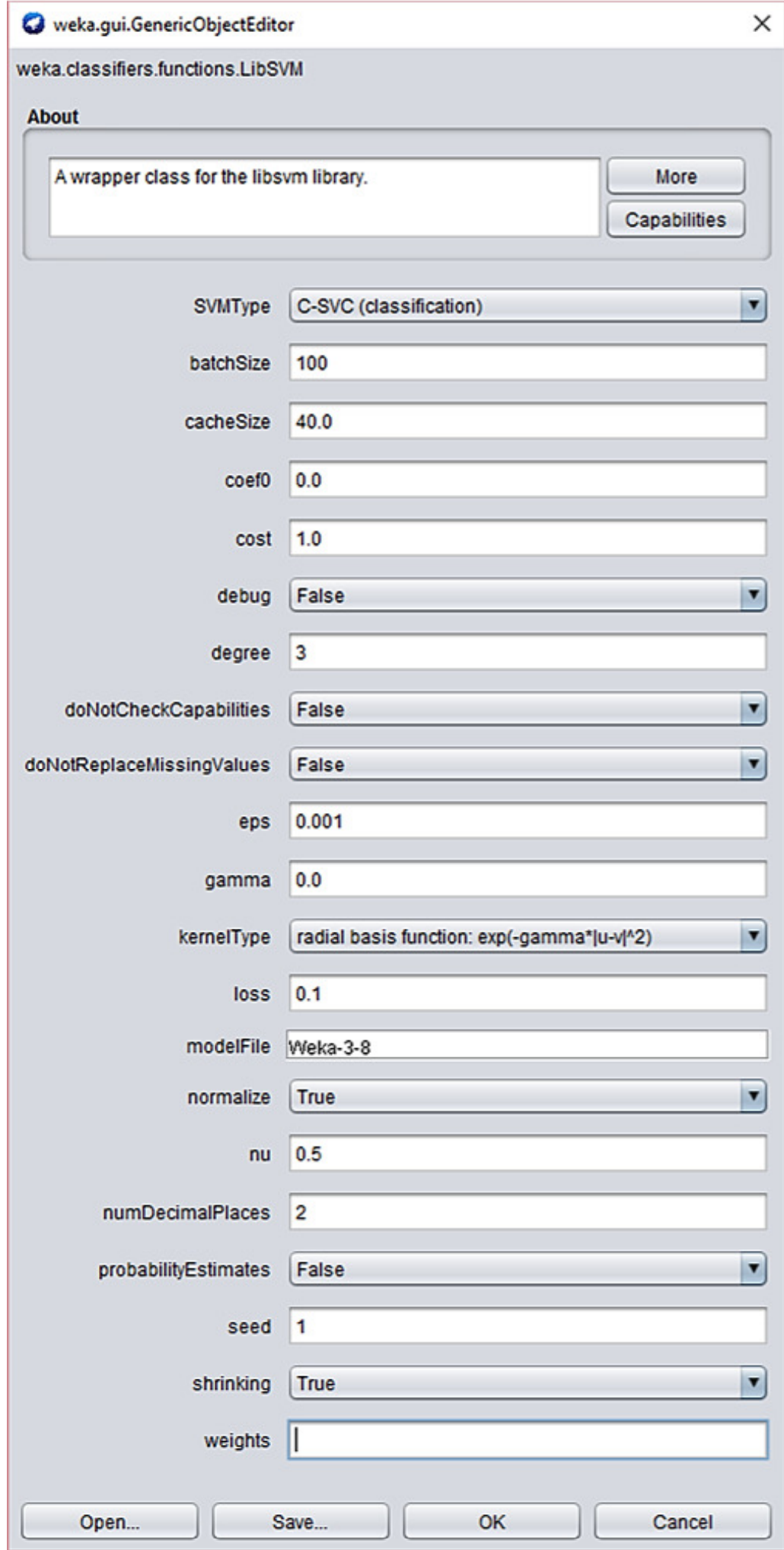

Figura 66 - Seleção do tipo do classificador e de suas propriedades. 